\title{
ЧОРНОМОРСЬКИЙ РЕГІОН У СВІТОВІЙ ПОЛІТИЦІ: АКТОРИ, ЧИННИКИ, СЦЕНАРІЇ МАЙБУТНЬОГО
}

\author{
МОНОГРАФІЯ
}

За загальною редакцією О. І. Брусиловської, В. А. Дубовика, I. М. Коваля

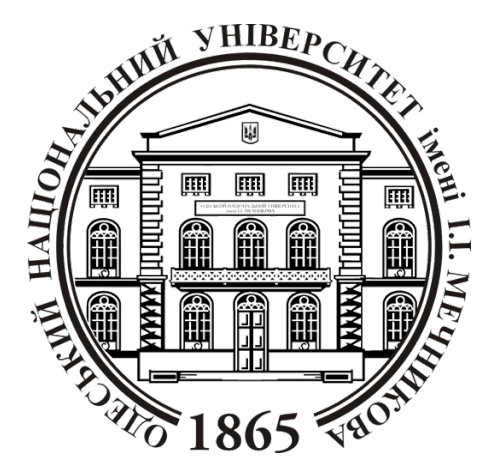

ОДЕСА 
УДК 327-049(1-4)(262.5):061.1€C+(1-622НАТО)

Ч-755

\section{Рецензенти:}

Даніела Іррера - доктор політичних наук, професор, заступник декана з наукової роботи та з міжнародних зв'язків департаменту координації міжнародних зв'язків факультету політичних та суспільних наук Катанійського університету, Італія;

Анэсела Качуєвські - доктор політичних наук, доцент кафедри історії та політичних наук університету Аркадія, Гленсайд, США;

Всеволод Самохвалов - доктор міжнародних відносин Кембриджського університету, Великобританія; ад’юнкт-професор департаменту міжнародних відносин, Вільного університету Брюсселя, Бельгія.

Рекомендовано до друку вченою радою ОНУ імені I. І. Мечникова

Протокол № 3 від 27 жовтня 2020 р.

Усі права захищено. Розповсюдження й тиражування без офіційного дозволу видавництва заборонено.

Ч-755 сценарії майбутнього : монографія / колектив авторів ; за заг ред. О. І. Брусиловської, В. А. Дубовика, І. М. Коваля. - Одеса : Одес. нац. ун-т ім. І. І. Мечникова, 2020. - 176 с.

ISBN 978-617-689-407-0

DOI $10.18524 / 978-617-689-407-0$

У монографії досліджено проблеми Чорноморського регіонуй зроблено висновок щьодо набуття поняттям ЧР суто географічного сенсу; для країн ЧР більше значення має приналежсність до підсистем (РПК, НСЕ, ЦСС та ПСС), аніж до системи ЧР. Поясненням є ступень зростаючої небезпеки у відносинах країн-сусідів; множсинність вузлів протиріч негативно впливає на малі країни регіону. Дисфункиія ЧР об 'єктивно впливає на дисфункиію української політики. У перспективі розвиток регіону визначатимуть Туреччина та Росія, які будуть тим більш успішними, чим мени узгодженою буде політика СС та НАТО. У ции умовах сценарій співпрачі Туреччини та Китаю може стати найбільш прийнятним для більшості чорноморських акторів.

Видання призначено для всіх, хто иіккавиться міжнародними відносинами - від студентів до експертів.

УДК 327-049(1-4)(262.5):061.1СС+(1-622HАТО)

ISBN 978-617-689-407-0

DOI $10.18524 / 978-617-689-407-0$
(C) Колектив авторів, 2020

(C) Одеський національний університет імені

I. I. Мечникова, 2020 


\section{MICT}

ПЕРЕДМОВА

4

(Коваль I. М.)

РОЗДІЛ 1. СТРУКТУРНИЙ РЕАЛІЗМ VS КОНСТРУКТИВІЗМ?

СУЧАСНІ НАУКОВІ ПІДХОДИ ДО ВИВЧЕННЯ

ЧОРНОМОРСЬКОГО РЕГІОНУ

(Брусиловська О. І.)

РОЗДІЛ 2. ПОЛІТИКА ТУРЕЧЧИНИ У ЧОРНОМОРСЬКОМУ

РЕГІОНІ: БАЛАНС СИЛ, ЗАГРОЗ ТА ІНТЕРЕСІВ

(Габер $\boldsymbol{C}$. В.)

РОЗДІЛ 3. АНЕКСІЯ КРИМУ: ПРАВОВІ ТА БЕЗПЕКОВІ

ПЕРТУРБАЦІЇ

(Глебов С. В.)

РОЗДІЛ 4. РОСІЙСЬКИЙ ЧОРНОМОРСЬКИЙ ФЛОТ:

ЧИ Є МІСЦЕ ДЛЯ СТРАТЕГІЧНОГО ВИМІРУ?

(Сіновець П. А.)

РОЗДІЛ 5. ПОЛІТИКА ЄС ЩОДО ЧОРНОМОРСЬКОГО РЕГІОНУ:

КОНФЛІКТ ІНТЕРЕСІВ, ВІДПОВІДАЛЬНОСТІ ТА ЗАГРОЗ 85

(Максименко I. В.)

РОЗДІЛ 6. НАТО У ЧОРНОМОРСЬКОМУ РЕГІОНІ:

ТРАНСФОРМАЦІЯ ПІДХОДІВ ТА ЦІЛЬОВА ПРИСУТНІСТЬ 101 (Шелест Г. В.)

РОЗДІЛ 7. ОСОБЛИВОСТІ СУЧАСНОГО ПІДХОДУ КИТАЮ ДО КРАЇН ЧОРНОМОРСЬКОГО РЕГІОНУ

(Брусиловська О. I.)

РОЗДІЛ 8. КРАЇНИ ЧОРНОМОРСЬКОГО РЕГІОНУ

У ЗОВНІШНІЙ ПОЛТТИЦ ЯПОНІї:

ICТОРІЯ ТА СУЧАСНІСТЬ 144

(Удовік В. В.)

ВИСНОВКИ 167

(Коваль І. М.)

АВТОРСЬКИЙ КОЛЕКТИВ 


\section{ПЕРЕДМОВА}

Політичні, економічні та культурні кордони, як правило, є відмінними від географічних; це стосується й Чорноморського регіону (ЧР). 3 Чорним морем межує всього шість країн: Болгарія, Румунія, Україна, Росія, Грузія та Туреччина. Але Хартію про чорноморське співробітництво - ЧЕС (BSEC) - підписали також Албанія, Молдова, Азербайджан, Вірменія та Греція. Молдову географічно можна віднести до Чорноморського регіону, адже вона розташована між Україною та Румунією близько до Чорного моря. Греція наближена до гирла Босфору, що з'єднує Чорне та Середземне моря. Вірменія не межує з Чорним морем, але розташована недалеко від нього. Ще дві країни розташовані на берегах інших морів, пов'язаних з Чорномор'ям безліччю зв'язків: Азербайджан - Каспійського, Албанія - Адріатичного. Тому за основу визначення ЧР взято саме підписання ЧЕС, що стало підгрунтям для сучасних економічних та політичних взаємозв'язків 11-ти країн регіону.

Однак, актуальність монографії пов'язана насамперед з тим, що ОЧЕС так і не стала основним полем інтеракцій чорноморських держав. Навпаки, їі сьогоднішній стан можна умовно охарактеризувати як «коматозний». Саме тому колективна монографія присвячена, по-перше, виявленню особливостей поведінки головних системних та позасистемних акторів, що визначають розвиток регіональної системи Чорноморського peziону, а, по-друге, виявленню чинників, що впливають на цих акторів, і метою прогнозування їх поведінки на середньострокову перспективу.

Метою монографії $є$ виявлення причин занепаду Чорноморської регіональної системи. Дослідницька дилема може бути сформульована таким чином: наскільки цей занепад є результатом дій двох регіональних лідерів - ТР та РФ, а в якій - позасистемних акторів. Серед завдань можна виокремити такі: визначення сучасних теоретичних підходів, які найбільш адекватно допомагають дослідити динаміку розвитку Чорноморського регіону; виявлення особливостей: а) політики Туреччини та Росії як регіональних лідерів Чорноморського регіону; б) політики СС та НАТО як найбільш впливових міжнародних організацій; в) політики Китаю та Японії як позасистемних акторів, чий вплив на Чорномор'я постійно зростає.

Важливими для цієї монографії $є$ поняття системних та позасистемних акторів. Тому для дослідження було обрано системний підхід, який надав можливість: 1) розглядати досліджуваний об'єкт (ЧР) як складну систему вхідних та вихідних сигналів; встановити зв'язок системи з її середовищем (світовою політикою, яка проявляється в політиці ос- 
новних світових акторів); 3) конкретизувати досліджуваний об'єкт (ЧР) як систему, що $є$ обмеженою внутрішньо визначеними зв'язками між елементами. Системний підхід до явища містить аналіз: 1) елементів, 3 яких складається система; 2) закономірностей виникнення та розвитку явища; 3) його еволюції; 4) причин змін; 5) сутності та законів розвитку. Застосування системного підходу уможливило поділ ЧР на низку підсистем (систем нижчого рівня, як-от: регіональні лідери, країни-новачки ЄC, країни Нової Східної Свропи, країни Регіону Південного Кавказу), й аналіз узгодження цілей кожної підсистеми з загальною метою системи, а також прикінцеву побудову ієрархії системи та ієрархії чинників, що створюють цю систему та сприяють їі функціонуванню. Чільне місце у дослідженні відведено вивченню прямого й зворотного зв'язків ЧР з ЄС, НАТО, Китаєм, Японією, що є осередком регіональної системи, яка досліджується.

Додатковими методами дослідження було обрано прогностичний метод та метод кейс-стаді, який надає можливість не тільки дослідити окремі випадки, а й застосувати отримані знання у подальших наукових розвідках щодо інших кейсів. Побудова сценаріїв є засобом прогнозування, встановлення логічної послідовності, коли за основу взято існуючу або задану ситуацію. Усі сценарії зосереджено на зв'язках між подіями, на критичних точках, де впливи можуть бути найбільш ефективними. Тому дослідження місця ЧР у світовій політиці було б не повним без спроби надати сценарій розвитку подій на найближчі десятиліття.

Монографія зосереджена на тих напрямах розвитку відносин в Чорноморському регіоні, які протягом років досліджували у своїх наукових пошуках співробітники кафедри міжнародних відносин ОНУ імені I. I. Мечникова. Відповідно до цього працю структурно поділено на вісім розділів, кожний з яких висвітлює окремий напрям зовнішньої політики міжнародних та національних акторів.

Праця розрахована на всіх, хто цікавиться зовнішньою політикою та міжнародними відносинами - від студентів до експертів. 


\title{
РОЗДІЛ 1 \\ СТРУКТУРНИЙ РЕАЛІЗМ VS КОНСТУРКТИВІЗМ? СУЧАСНІ НАУКОВІ ПІДХОДИ ДО ВИВЧЕННЯ ЧОРНОМОРСЬКОГО РЕГІОНУ
}

(Брусиловська О. I.)

\author{
Liberalism is a many-headed creature \\ (Jorgensen, 2010, p. 57) \\ Structures never tell us all that we want to know. \\ Instead they tell us a small number of big and important things \\ (Waltz, 1979, p. 72)
}

\begin{abstract}
Bcmyn
Чорноморський регіон являє собою певну усталену структуру, основними акторами якої є держави (великі й малі) та наднаціональні сили (ЄС, НАТО, ОЧЕС та ін.). Не дивно, що для дослідження Чорноморського регіону (ЧМР) було обрано структурний реалізм. У цьому розділі також розглядається ліберальна традиція дослідження міжнародних відносин (MB), а саме конструктивізм. Це пояснюється певними прогалинами структуралізму, які мають бути доповнені за допомогою альтернативної Teopiï.

Неореалісти стверджують, що великі держави приділяють увагу балансу сил і конкуренції для того, щоб отримати владу за рахунок інших або хоча б не втратити свою силу/владу. Вони роблять так тому, що анархічна структура міжнародної системи залишає невеликий вибір, якщо вони хочуть вижити. Ці змагання за владу створюють небезпечний світ, в якому великі держави борються одна з одною. Концентрація уваги дослідників на великих державах засвідчує, що положень структуралістської теорії може виявитися недостатньо для аналізу регіону, в якому більшість гравців є малими державами.

Натомість конструктивісти розглядають МВ як соціальний конструкт, як те, що може бути змінено свідомими акторами в процесі взаємодії. Якщо реалісти оперують таким основними поняттями, як «інтереси», «сила/міць» та «баланс», то для конструктивістів важливими $є$ питання «ідентичності», «мови» та «причинності» в МВ, що, на нашу думку, вкрай важливо для розуміння поточних процесів у ЧМР, який історично був полем взаємодій акторів з різним релігійним, культурним та ідеологічним корінням.
\end{abstract}


Проблема полягає в тому, що обидві школи наукової думки, хоча й найбільш актуальні для аналізу сучасних міжнародних студій, дисонують більше, аніж резонують, що порушує питання про їх сумісність у рамках інтегрального наукового дослідження. Отже, розділ має на меті вияснити, що може бути запозичене з кожної сторони так, щоб їх наукові ідеї доповнювали одна одну, а не порушували наукову єдність структури дослідження.

\section{Структурний реалізм}

Реалісти від Ханса Моргентау до Джона Міршаймера вважають, що влада (сила, міць, потуга) є віссю міжнародної політики. Важливо не тільки мати значну кількість влади, але й бути переконаним, що жодна інша держава не змінює баланс сил на свою користь. Для реалістів «міжнародна політика» є синонімом «силової політики».

Структурні реалісти (неореалісти) - це течія, яка, на думку Кнута Еріка Йоргенсена, є скоріше додатковою та новаторською (перші дебати в реалістичній традиціi), аніж просто продовженням класичного реалізму. Вони відштовхуються від класичного реалізму як «пункту відправки», а потім розривають зв'язки з традицією (Jorgensen, 2010, c. 84). Натомість Баррі Бузан (Buzan, 1993) та Гленн Снайдер (Snyder G., $1997)$ розвинули класичний реалізм, збагачуючи його новими змінними - «взаємодія» та «союзи» відповідно (другі дебати). Зазначимо, що, за Йоргенсеном, є ще й пост-неореалісти, які кровно пов'язані з класичною традицією й «мстяться» неореалістам за їх відрив від основ (треті дебати) (Jorgensen, 2010, с. 85).

Неореалісти стверджують, що сама структура міжнародної системи змушує великі держави прагнути влади. У системі, де немає вищого авторитету, аніж великі держави, де немає гарантії, що одна не нападе на іншу, надзвичайно важливо бути сильною державою, щоб захистити себе у випадку атаки. По суті, великі держави замкнені в клітці, в них немає вибору, тому залишається тільки конкурувати одна з одною за владу, якщо вони сподіваються вижити (Mearsheimer, 2013, с. 78).

У цьому сенсі еволюція міждержавних відносин у Чорноморському регіоні може бути гарною ілюстрацією до вищезазначеної тези, адже після закінчення «холодної війни» та ослаблення Росії регіон став ареною конкуруючих амбіцій РФ та Туреччини. Якщо їм не вдалося налагодити співробітництво у 1990-ті рр., тим менше шансів залишилося з приходом до влади В. Путіна та відродженням великодержавних претензій РФ.

Для нашого дослідження важливо усвідомити, у чому полягає недосконалість структурно-реалістичної теорії: вона ігнорує культурні від- 
мінності між державами, а також відмінності у типі режиму, тому що, на їх переконання, міжнародна система створює однакові стимули для всіх. Демократичність чи авторитарність держави відносно мало впливає на iii політику щодо інших держав. Не має великого значення і той факт, хто відповідає за проведення зовнішньої політики. Структурні реалісти ставляться до держав як до «чорних ящиків»: вони «повинні» бути однаковими за винятком того, що деякі держави є впливовішими.

На нашу думку, не розуміючи природи режимів РФ та РТ, неможливо дослідити еволюцію їх політики в Чорноморському регіоні: безліч фактів свідчать про недемократичний характер цих режимів, що ускладнює не тільки двосторонні стосунки, але й відносини з іншими, більш слабкими державами ЧМР. Отже, у цьому пункті структурний реалізм має бути доповнено здобутками альтернативної теорії.

Подальший аналіз структурного реалізму обертається навколо таких основних питань. По-перше, чому великі держави в міжнародній анархії бояться одна одну? По-друге, що таке дилема безпеки та чи є рішення для неї? По-третє, скільки влади вони хочуть?

Структурні реалісти спираються на п’ять основних припущень (для них - аксіом) про міжнародну систему. Перше припущення: великі держави є головними у світовій політиці й діють за анархічною системою (Jorgensen, 2010, с. 84). Це не означає, що система характеризується хаосом / безладом; анархія - це принцип упорядкування, який означає, що не існує централізованої влади або арбітра, який стоїть над державами. Протилежною до анархії є ієрархія - принцип упорядкування внутрішньої політики. Друге припущення: всі держави мають певний військовий потенціал; кожна держава може завдати шкоди своєму сусідові. Третє припущення: держави ніколи не можуть бути впевненими в намірах інших держав; держави хочуть знати, чи інші держави мають намір використати можливості для зміни балансу сил (ревізіоністські держави), чи вони достатньо задоволені цим балансом, щоб не цікавитися використанням сили для його зміни (статус-кво держави). Проблема полягає в тому, що майже неможливо визначити наміри іншої держави. На відміну від військових можливостей, наміри не можуть бути перевірені емпірично, оскільки вони залежать від рішень певних осіб, їх не можна визначити й оцінити за виступами політиків і документами, які підписують на найвищому рівні. Реалісти зазначають, що політики брешуть (іноді) або приховують свої справжні наміри (завжди). Навіть якби можна було визначити наміри іншої держави сьогодні, неможливо визначити іï наміри щодо завтра. Неможливо знати, хто буде вести зовнішню політику в державі через п’ять або десять років, чи будуть ці 
наміри агресивними. Актор ніколи не може бути впевнений, чи має він справу з ревізіоністською державою чи з державою статус-кво. Четверте припущення: головною метою держав $\epsilon$ виживання. Держави прагнуть зберегти свою територіальну цілісність та автономію внутрішньополітичного порядку. Вони можуть мати на меті процвітання й захист прав людини, але це $\epsilon$ другорядним питанням, порівняно з питанням виживання. П'яте припущення: держави є раціональними суб'єктами, тобто вони здатні розробити розумні стратегії, які максимізують перспективи для виживання (Mearsheimer, 2013, с. 78). Оскільки держави працюють із недосконалою інформацією в складному світі, іноді вони допускають серйозні помилки.

Жодне із цих припущень не засвідчує того, що держави повинні конкурувати за владу. Тільки тоді, коли всі припущення об'єднані, вважають реалісти, виникають обставини, коли держави не тільки стурбовані балансом сил, але й набувають потужних стимулів для отримання влади в боротьбі з іншими державами.

Почнемо з того, що держави бояться одна одну, турбуються про наміри інших держав ще й тому, що їх так складно передбачити. Найбільший страх полягає в тому, що інша держава може мати можливість та мотив атакувати. Рівень страху між державами варіюється, але його не можна знизити до несуттєвого. Міжнародна політика - це справа, в якій існує постійна можливість війни, що означає масові вбивства в державі й за іiі межами й призводить до знищення держави загалом. Ця небезпека посилюється тим, що держави діють за анархічною системою. Це означає, що немає «нічної варти», яка могла б врятувати їх, за умови загрози з боку іншої країни. Якщо немає вищого авторитету, до якого вони можуть звернутися, це не означає, що держави можуть створювати союзи, корисні для боротьби з небезпечними супротивниками. Зрештою, у держав немає іншого вибору, як ставити свої інтереси вище за інтереси інших держав та так званого міжнародного співтовариства (Mearsheimer, 2013, c. 79).

Побоюючись інших держав і знаючи, що вони діють у світі самодопомоги, держави швидко усвідомлюють, що найкращий спосіб вижити - це бути могутнім. Аргументація тут прямолінійна: чим сильніша держава, тим менша ймовірність того, що на неї нападуть. Ця проста логіка спонукає великі держави шукати можливості змінити баланс сил на свою користь. Звичайно ж, кожна з держав у системі розуміє, що це призведе до безперервної конкуренції за владу. По суті, структура системи змушує кожну велику державу, у разі необхідності, мислити й діяти як ревізіоністська держава. Мирне співіснування можливе лише за умови, 
якщо всіх влаштовуватиме статус-кво. Однак проблема полягає в тому, що держави не можуть бути впевнені в намірах одна одної. Сьогодні це може бути статус-кво, а завтра ні. В анархічній системі, де немає остаточного арбітра, держави, які хочуть вижити, не мають іншого вибору, окрім як припускати найгірші наміри щодо інших держав і боротися 3 ними за владу (Mearsheimer, 2013, с. 80).

Це трагедія великодержавної політики. Якщо вище зазначалося, що в сучасній Росії штучно (зверху) відбулося відродження ідеології великодержавності, то подальша політика в ЧМР $є$ підтвердженням негативних наслідків такої політики (економічні втрати, загострення відносин з США, НАТО та СС), того, що РФ не контролює ситуацію, а радше $€$ іiї заручницею.

Структурні імперативи, описані вище, відображені у відомій концепції дилеми безпеки. Суть цієї дилеми полягає в тому, що більшість кроків, які робить велика держава для підвищення власної безпеки, знижують безпеку інших держав. Наприклад, будь-яка країна, яка покращує своє становище в глобальному балансі сил, робить це за рахунок інших держав, які втрачають відносну владу. Звичайно ж, під загрозою зникнення держави роблять все можливе для забезпечення свого виживання, що може загрожувати іншим державам.

Реалісти погоджуються, що ядерна зброя мало придатна для наступальних цілей, за винятком того, коли вона є тільки в однієї сторони конфлікту. Причина проста: якщо ядерна зброя наявна в обох сторін, жодна з них не матиме переваги й війна є малоймовірною в зв'язку небезпекою ескалації до ядерного рівня.

Але серед реалістів існують великі розбіжності щодо того, скільки влади держава повинна прагнути.

Оборонні реалісти визнають, що міжнародна система створює відповідні стимули для отримання додаткових прирощень влади, стверджуючи, водночас, що стратегічно нерозумно переслідувати гегемонію. Це означатиме надмірне розширення й призведе до гірших наслідків. Держави не повинні максимізувати владу, але замість цього повинні прагнути того, що Кеннет Уолц називав «відповідною кількістю влади» (Waltz, 1979 , с. 40).

«Теорія міжнародної політики» Кеннета Уолца (1979) - основоположний текст структурного реалізму i, можливо, найвпливовіша книга, написана в галузі міжнародних відносин за останні півстоліття. Йоргенсен назвав іiї «найкращим продуктом раціоналістичного мислення» (Jorgensen, 2010, с. 84). Основна теза Уолца полягає у тому, що відсутність вищого авторитету, до якого великі держави можуть звернутися 
в умовах кризи, в поєднанні з їх інтересом до виживання, не залишає державам іншого вибору, окрім боротися за владу одна $з$ одною. Має сенс нарощувати сили, за умови виникнення проблем, якщо вам доводиться покладатися на лише себе. Зрештою, сильніші держави менш схильні до нападів, ніж слабші. Уолц, стверджує, що держави не повинні намагатися максимізувати свою владу, тому що спроби отримати більше влади можуть легко призвести до зворотного результату. Вони, безумовно, не повинні прагнути гегемонії. Головна мета повинна полягати в тому, щоб інші держави не отримували владу за їх рахунок. «Перша турбота держав, - зазначає він, - не в максимізації влади, а в збереженні їх позицій у системі». Крім того, Уолц не припускає, що «вступ у війну» для отримання влади має стратегічний сенс. Уолц стверджує, що держава повинна стримати свій апетит до влади через переважання врівноваженої поведінки. Держави майже завжди перевіряють конкуруючі держави, які прагнуть стати особливо могутніми. Держави, яким загрожують, можуть створити власні можливості, «внутрішню рівновагу» або об'єднатися й сформувати балансуючу коаліцію - «зовнішню рівновагу».

«Теорія міжнародної політики» містить кілька інших важливих ідей. Уолц стверджує, що біполярні системи більш мирні, ніж багатополярні. Спираючись на системні принципи, з позицій яких полярність системи розглядається як їі структурна характеристика, Уолц доводив, що зовнішньополітична поведінка держав залежить від так званої «системної напруженості». Між державами діють певні «системні обмежувачі», які врешті-решт і визначають зовнішню політику. В цьому й полягає причина різного рівня залучення держав до світової політики. Для того, щоб зрозуміти чи спробувати передбачити поведінку держав на міжнародній арені, потрібно враховувати особливості міжнародної системи, специфіку іï структури. Саме ця категорія, за Уолцом, дає розуміння того, яким чином позиції держав відрізняються одна від одної, і як вони зіставлені з точки зору здатності до дій (Waltz, 1979, с. 80). Зокрема, міжнародна система в біполярному світі сильніше пригнічує свої складові частини, тоді як за багатополярного устрою держави мають більше свободи для військового вирівнювання (Waltz, 2001, с. 158).

Наприклад, структура світової системи за часів «холодної» війни вимагала чіткого визначення зовнішньополітичної орієнтації та приєднання до одного з двох ворогуючих блоків, що значно обмежувало можливості регіональних держав у проведенні самостійної зовнішньої політики. На відміну від біполярної, у багатополярній системі вибір союзників чітко не визначається структурою системи, натомість обумовлюється національними інтересами кожної держави, що значно розширює коло іiі 
потенційних партнерів і противників й дозволяє переглянути своє місце в системі міжнародних відносин.

Якщо в період біполярності система накладала жорсткі обмеження на структурні одиниці й суттєво обмежувала їхні дії, то з розпадом СРСР було значно розширено простір для зовнішньополітичного маневрування малих та середніх держав. Цю тенденцію до активізації зовнішньополітичної діяльності можна простежити на прикладі політики Анкари в Чорноморському регіоні.

Структурні зміни в системі відбуваються не часто, тому в 1991 році виник унікальний шанс перерозподілу функцій між іiі членами. Зокрема, для Туреччини це була можливість змінити принцип відносин зі Сполученими Штатами з моделі «суб'єкт-об'єкт» на «суб'єкт-суб'єкт», принаймні в регіональному контексті. В умовах нового світового устрою рівень системної «напруженості» став значно нижчим, дія структурних обмежувачів на формування зовнішньої політики регіональними державами послабшала, відтак Анкара об'єктивно отримала можливість проводити більш різноманітну, багатовекторну політику, часто всупереч інтересам США. За логікою неореалістів, в таких умовах головним мотивом Туреччини, як і будь-якої іншої регіональної держави, стає прагнення врівноважити сили наймогутнішої держави (США) шляхом об'єднання з іншими учасниками системи (насамперед, Росією).

Навіть для Кеннета Уолца в його ранніх працях політика балансу сил, яка виражається в нарощуванні власної могутності чи створенні союзів, не є єдиною можливою. Перед країною відкриті й інші стратегії - наприклад, вона може приєднатися до сильнішої держави або ж, навпаки, може сама домагатися стану лідера. Уолц також визнає, що за ієрархічного устрою «другорядні» держави («secondary states») більш вмотивовані в збільшенні своїх абсолютних зисків (навіть якщо вони будуть дещо меншими, порівняно з іншими учасниками системи). I задля цього вони, скоріш за все, будуть переходити на сторону могутніших держав (Waltz, 1979, с. 161-194). На практиці це означає, що коли $є$ можливість «перекласти відповідальність на плечі іншого», більшість країн скористається такою нагодою аби зменшити ризики та витрати, які є неминучими при балансуванні (Posen, 1984, с. 64).

Уолц також вказує на важливу відмінність між балансуванням і «банд-вагонінгом». Останнє буде притаманне державі, яка об'єднує сили з висхідною державою, котра виграє війну й здобуде владу. Уолц стверджує, що балансування - це поведінка, викликана системою, тому що держави не хочуть бути вразливими. Він наводить аргумент, що співпраця між державами ускладнена через побоювання «відносних вигод». 
Укладати угоди складно, оскільки держави побоюються, що інша сторона отримає більше і скористається розстановкою сил на свою користь.

Отже, за Уолцем, стриманість держав є результатом трьох факторів. Якщо будь-яка держава стане занадто сильною, інші великі держави задля балансування створять збройні сили та сформують коаліції, які залишать гегемона в меншій безпеці i, можливо, навіть знищать його. Навіть коли завоювання здійсненне, воно не окупається: витрати переважують вигоди. Через «націоналізм» переможцю особливо складно, а іноді неможливо підпорядкувати переможених. Ідеологія націоналізму, повсюдна й потужна, заснована на самовизначенні, яке фактично гарантує, що окуповане населення повстане проти окупанта. Крім того, іноземцям складно експлуатувати сучасну економіку, головним чином тому, що інформаційні технології вимагають відкритості та свободи. Навіть у тих рідкісних випадках, коли великі держави завойовують іншу державу, вони мають мало користі але багато неприємностей. Ці основні факти $з$ життя всіх держав у міжнародній системі $є$ очевидними й повинні обмежувати апетит до більшої влади. Якщо всі держави визнають таку логіку (а вони повинні це робити, якщо вважають себе раціональними суб'єктами), конкуренція у сфері безпеки не повинна бути особливо інтенсивною, й має бути мало конфліктів, в яких беруть участь всі або майже всі великі держави (Mearsheimer, 2013, с. 82).

Уолц, розуміючи неповноту своїх відповідей на основні питання $\mathrm{MB}$, стверджував, що його «теорія міжнародної політики» повинна бути доповнена окремою «теорією зовнішньої політики», яка могла б пояснити помилкову поведінку держави. Д. Фірон зазначив, що Уолц мав на меті пояснити поведінку держави, iii різні варіанти (balancing, bandwagoning, seeking relative or absolute gains), й структуралізм у цьому сенсі - це теорія зовнішньої політики держави (Fearon, 1998, с. 290).

Зауважимо також, що «додаткова теорія», яка на думку Уолца повинна звернутися до аналізу внутрішньополітичних чинників, вже ніяк не вкладається в теорію структурного реалізму. Інакше кажучи, ми повинні знайти інші теорії, щоб відповісти на питання, які тривожили К. Уолца.

Пізніше оборонні реалісти, такі як Баррі Позен, Джек Снайдер і Стівен Ван Евера, підтвердили, що без альтернативної теорії не можна пояснити, чому великі держави діють нестратегічними способами. 3 цією метою Позен (Posen, 1984) спирається на організаційну теорію, Снайдер (Snyder, 1991) - на теорію внутрішнього режиму, а Ван Евера (Van Evera, 1999) - на мілітаризм. Стівен Уолт (Walt, 1987), спираючись на організаційну теорію, приділив велику увагу соціальним факторам 
і створив концепцію «балансу загроз», що передбачає залучення таких важливих змінних поведінки держави як «свідомість» та «самосвідомість». Уолт та Снайдер дослідили, як політичні еліти стають заручниками своєї політичної риторики. Нематеріальні та внутрішні чинники до своїх емпіричних досліджень додали Джек Снайдер (Snyder, 1991), Колін Елман (Elman, 1996), Семюел Хантінгтон (Huntington, 1996), Генрі Но (Nau, 2002) і таким чином довели, що «реалізм й «культурний» фактор не $\epsilon$ антитезами» (Jorgensen, 2010, с. 86). Сучасні дослідження структуралістів (Чарлз Глейзер, Рендалл Швеллер та Девід Пріс), які акцентують увагу не на державах як головних гравцях, а на міжнародних організаціях, стверджують, що вони дійсно мають значення, можуть мінімізувати дилему безпеки, а також страх перед обманом, притаманний кожній державі (Glaser, 1995; Schweller \& Priess, 1997). Водночас Йоргенсен наголошує, що це все поодинокі випадки й в цілому неореалісти не приділяють систематичної уваги вимірам соціальної реальності; їм слід було б доповнити гасла такими поняттями як «моральність», «етика» та «ідентичність» (Jorgensen, 2010, с. 86).

Отже, оборонні реалісти повинні вийти за межі структурного реалізму, щоб пояснити, як держави діють у міжнародній системі. Вони повинні об'єднати теорії внутрішнього й системного рівня, щоб пояснити, як влаштовано світ.

Наступальні реалісти схильні покладатися виключно на структурні аргументи для пояснення міжнародної політики. Вони визнають, що держави іноді діють стратегічно нерозумно, і що ці випадки суперечать їхній теорії. Але це все, в чому наступальні реалісти погоджуються 3 Уолцем та іншими оборонними реалістами.

Наступальні реалісти вважають, що держави повинні шукати можливості отримати більше влади щоразу, коли це можливо. Держави повинні максимізувати владу, тож їх кінцевою метою повинна бути гегемонія. Наступальні реалісти, такі як Джон Міршаймер (Mearsheimer, 2001), аргументують це тим, що бути впливовим є найкращим засобом забезпечити своє виживання. Якщо для класичних реалістів влада - це самоціль, то для структурних реалістів, влада - це засіб для досягнення мети, а кінцевою метою є виживання. Влада заснована на матеріальних можливостях держави. Баланс сил - це функція матеріального військового майна, наявного в державі (бронетанкові дивізії та ядерна зброя). Проте, держави мають й інший вид сили, приховану силу, що належить до соціально-економічних складових з нарощуванням військової потужності. Це латентна влада, заснована на багатстві держави й чисельності населення. Прихована сила належить до потенціалу, який можна вико- 
ристовувати, конкуруючи з іншими державами. 3 цієї дискусії зрозуміло, що війна не єдиний спосіб, за допомогою якого держави можуть отримати владу. Вони також можуть зробити це, збільшивши чисельність свого населення та свою частку у світовому багатстві.

Ця теорія знаходить підтвердження в ЧМР - як на основі вивчення «політики великих потуг», так і позасистемних акторів, таких як Китай та Японія. Ці гравці є відносно новими силами на чорноморському просторі, але вже продемонстрували неабиякі успіхи на шляху до перерозподілу влади.

Наступальні реалісти стверджують, що балансування часто неефективне, особливо коли йдеться про формування коаліцій, і що ця неефективність надає певні можливості для розумного агресора. Крім того, держави, яким загрожують, іноді вважають за краще не вступати до коаліції; вони намагаються змусити інші держави взяти на себе тягар перевірки сильного противника, поки вони залишаються осторонь. Така поведінка також створює можливості для агресії. Наступальні реалісти заперечують твердження, що захисник має значну перевагу перед нападником. Дійсно, історичні дані засідчують, що сторона, яка ініціює війну, частіше перемагає, ніж програє. Хоч наступальні реалісти визнають, що, зазвичай, завоювання не окупається, вони також зазначають, що іноді це виправдовує себе. Завойовники можуть використовувати економіку переможеної держави заради вигоди. Пітер Ліберман стверджував, що інформаційні технології мають «оруеллівський» вимір, який сприяє репресіям (Liberman, 1996, с. 126). Більше того, державі, що перемогла, не потрібно займати переможену державу, щоб отримати над нею перевагу. Переможець може анексувати частину території переможеної держави, розбити її на дві або більше невеликих держав або просто роззброїти та перешкоджати переозброєнню.

Чи не нагадує це безпосередній виклад особливостей політики України, пов'язаних із коливаннями «нейтралітет - НАТО», «Схід - Захід», та її наслідків, таких як втрата Криму й гібридна війна?

Усі структурні реалісти визнають, що держави можуть розпочати війну з ряду причин, отже, неможливо висунути теорію, яка б зазначила один фактор як основну причину конфлікту. Безпека не завжди є головною рушійною силою для рішення про початок війни. Ідеологія або економічні міркування іноді мають більше значення. Наприклад, націоналізм був основною причиною того, що Бісмарк розпочав війни проти Данії, Австрії, Франції: він хотів створити єдину Німеччину.

Зауважимо, що після «холодної війни» замість «кінця історії» ми теж отримали черговий виток відродження націоналізму як провідної 
ідеології сучасного світу з усіма його вигодами (консолідація націй) та невигодами (етнічні чистки, неповага до прав національних меншин, ідея розширення життєвого простору за рахунок «неповноцінних народів» - «держав, що провалилися»). Чи не є це зауваження реалістів відповіддю на питання, чому в еру тотальної інформатизації та зростаючого впливу громадянського суспільства на світову політику держави XXI ст. поводять себе так нераціонально?

Хоча виоремлення конкретної причини воєн/конфліктів не є плідним підходом, структурні реалісти стверджують, що на їх ймовірність впливає структура міжнародної системи.

Деякі стверджують, що ключовою змінною є кількість великих держав або полюсів у системі. Давні дебати між реалістами полягають у тому, чи є біполярність менш схильною до війни, ніж багатополярність, що досить спокусливо стверджувати на матеріалі XX ст. Однак така аргументація менш переконлива, коли часова шкала охоплює XIX ст.: 3 1815 по 1853 р., а потім з 1871 по 1914 р. не було ніякої війни між великими державами. Тривалі періоди відносної стабільності, які відбулися в багатополярній Європі, вигідно відрізняються від «холодної війни». Прихильники багатополярності також стверджують, що великі держави мають більше можливостей боротися одна з одною в багатополярній системі. У багатополярній системі є три потенційно конфліктні діади, коли є три або навіть більше великих держав. По-друге, в багатополярній системі великі держави є менш ворожими, тому що кількість уваги, яку вони приділяють одна одній, менше, ніж у біполярній. Держави не можуть дозволити собі надмірно турбуватися про одного із своїх сусідів; вони повинні поширювати свою увагу на всі великі держави. Із закінченням «холодної війни» та розпадом Радянського Союзу багато реалістів (Вільям Волфорт) стверджують, що настала монополярність (Wohlforth, 1999). Інакше и, США - єдина велика держава, вона досягла глобальної гегемонії. Інші, однак, стверджують, що система після «холодної війни» є багатополярною: США, безумовно, є найпотужнішою державою на землі, але є й інші великі держави, такі як Китай та Росія (Mearsheimer, 2013, c. 85).

Для нашого аналізу важливо, що всі три - США, РФ та Китай - $є$ залученими до взаємовідносин чорноморських країн, хоча їхній сучасний вплив $є$ вочевидь нерівнозначним. Але для наукового прогнозування, як і для розробки політичних стратегій майбутнього, визначення та розуміння стану сучасної системи МВ є необхідною передумовою. Авторська позиція полягає в тому, що якщо система МВ 1990-х рр. мала більшість ознак монополярності, то система MB XXI ст. має відмінні якості, які дозволяють говорити про іiї багатополярність. 
Замість того, щоб підраховувати кількість великих держав, щоб пояснити феномен війни, деякі реалісти стверджують, що ключовою змінною є те, скільки сили контролює кожна з цих великих держав. Сила може бути більш-менш рівномірно розподілена між великими потугами. Хоча співвідношення сил між усіма великими державами впливає на перспективи, ключовим є співвідношення між двома найбільш могутніми країнами в системі. Реалісти стверджують, що присутність особливо могутньої держави сприяє миру. Однак, війна між меншими державами все ще можлива, тому що баланс сил між будь-якими двома 3 них іноді буде приблизно рівним, що дозволяє припустити, що одна 3 них може перемогти іншу. Але навіть тоді, якщо панівна влада вважає, що такі війни можуть порушити сприятливий міжнародний порядок, у неї повинні бути можливості зупинити їх або, принаймні, зробити їх надзвичайними подіями (Mearsheimer, 2013, с. 86).

Частина ж реалістів стверджує, що помилковим є зосередження уваги на статичних показниках, таких як кількість великих держав або кількість сили, яку кожен з них має. Вони стверджують, що замість цього слід зосередитися на динаміці балансу сил, особливо на значних змінах, які відбуваються в розподілі влади (Copeland, 2000). Мабуть, найвідоміший аргумент полягає в тому, що переважна сила, що протистоїть висхідному супротивнику, створює особливо небезпечну ситуацію, наслідком якої, зазвичай, є центральна війна. Панівна держава, знаючи, що ii дні на вершині влади останні, має сильні стимули почати превентивну війну; держава на спаді повинна діяти, поки ще користується перевагою над своїм конкурентом. Деякі вчені стверджують, що висхідна держава також може почати війну (Mearsheimer, 2013, с. 87). Але це не має великого сенсу, тому що час на боці висхідної держави; їй не потрібна війна, щоб обігнати провідну державу.

Це теоретичне положення може бути застосовано для порівняльного аналізу політики РФ та СС в ЧМР: Росія виступає як переважна сила, що хоче повернути гегемонію над колишніми сателітами й протистоїть висхідному супротивнику («колективний Захід»). ЄС, навпаки, не потребує війни, щоб розширити сферу впливу, яка стала для організації важливою тільки після останнього розширення: держави регіону, в тому числі Туреччина, самі обрали шлях інтеграції до Євросоюзу.

Досліджуючи ЧМР, неможливо оминути базову працю Кріса Брауна щодо політики великих держав (Brown, 2004), яка доводить, що тільки в екстремальних випадках можуть «не зважати» одна на одну, культивувати вузьку, егоїстичну, короткозору концепцію національного інтересу; праці критика зовнішньої політики США Джона Міршаймера 
(Mearsheimer, 2003, 2006); одну з найбільш плідних праць із зовнішньої політики СС, яка належить Баррі Позену (Posen, 2004).

Тим не менш, структурний реаліст Джек Донеллі зазначає, що наразі «скоріше ніж «Теорї міжнародної політики» ми потребуємо теорій міжнародної політики, як реалістичних, так і нереалістичних, що разом дасть нам шанс змиритися з різноманітними людськими цілями та складними практиками і процесами, що складають світову політику» (Donnelly, 2000, с. 198). Зважаючи на вищезазначене, ми потребуємо вивчення не тільки матеріальних факторів, а й ідейних, соціальних та культурних, якщо хочемо зрозуміти таких «нераціональних» акторів як Росія, Китай та навіть ЄС.

\section{Конструктивізм}

Невдача провідних дослідників у передбаченні закінчення «холодної війни» на основі домінуючих теорій $\mathrm{MB}$ посилила важливість нових теоретичних викликів, у тому числі т. зв. «конструктивістського повороту» (Checkel, 1998). Конструктивісти критикували статичні матеріальні припущення традиційної ТМВ, окреслювали соціальні виміри MB та можливість їх зміни. Думка, від якої відштовхується конструктивізм - те, що МВ є соціальною конструкцією. За Ніколасом Онуфом, конструювати щось - це створювати суб'єкт чи об'єкт, які інакше не існували б. Матеріальні об'єкти, які не існують у природі, а виникли через акти «людського творіння» (Onuf, 1989), мають певне значення тільки в контексті. Вони є соціальними конструкціями, оскільки пронизані соціальними ичінностями та нормами. Держави, альянси чи міжнародні інститути, тобто колективні суб'єкти міжнародних відносин, торюються на людській природі, але приймають конкретні історичні, культурні та політичні форми, які є продуктом взаємодії людей у соціальному світі.

Можливо, найбільш амбітною стала праця Александра Вендта «Соціальна теорія міжнародної політики» (Wendt, 1999). Йоргенсен назвав іiї «конструктивістською ліберальною теорією міжнародної співпраці» (Jorgensen, 2010, с. 67). Як видно із заголовку, книга стала спробою опозиції «Теорії міжнародної політики» Кеннета Уолца, яка вийшла у світ на 20 років раніше. Якщо в реалізмі головне - матеріальні фактори, то в конструктивізмі - фактори соціальні. Якщо в реалізмі головне «анархічність МВ», то в конструктивізмі - можливість створення «анархічного співтовариства» на основі уваги до ідентичності партнерів та вироблення спільних норм. Іншими словами, інституції трансформують інтереси, а інтеракції змінюють і інтереси, і ідентичності. Ці міркування А. Вендта були дуже близькими до основних положень Англійської школи. Наприклад, стаття Тіма Данна 1995 р. «Соціальне конструювання 
міжнародного співтовариства» присвячена спільним нормам, які створюються самими державами (Dunne, 1995), й це дозволило Крісу Брауну та Кірстен Ейнлі назвати їх «кузенами за ТMВ» (Brown \& Ainley, 2009, c. 48). Щодо самого А. Вендта, то він зазначав, що хоч і вважає себе частиною «лояльної опозиції», все, чого він прагне - це діалог з послідовниками Уолца (Brown \& Ainley, 2009, с. 52).

Конструктивісти виокремили кілька тем. По-перше, ідея соціальної побудови передбачає різницю в контексті, а не в об'єктивній реальності. Традиційні теорії МВ надають пріоритет ідентифікації закономірностей. Конструктивісти ж прагнули зрозуміти та пояснити надзвичайні зміни після закінчення «холодної війни» важливістю історичного контексту й запитували, чи можливий перехід від конфлікту до співпраці, від миру до війни.

ЧМР надає багатий матеріал для підтвердження цієї тези, адже ідея співпраці колишніх ворогів була в основі міркувань Тургута Озала щодо організації ЧЕС ще у 1990 р., до розпаду СРСР; потім була програма ТРАСЕКА, створення ПАЧЕС, ЧБТР, проекту Ітурі т. ін. - успіхи та невдачі, які неможливо дослідити без контексту традиційних зв'язків чорноморських країн.

По-друге, конструктивісти наголошували на соціальних вимірах міжнародних відносин і продемонстрували важливість норм, правил та мови (Fierke, 2013, с. 189). Важливість «нового мислення» М. Горбачова для припинення «холодної війни», зростаюче значення поняття «гуманітарної інтервенції» та поширення ліберальних демократичних цінностей викликали критику виняткового акцентування реалістів на матеріальних інтересах та владі/силі.

Дійсно, саме трійця «норми, правила та мова» допомагає дослідити проблеми, які залишаються незрозумілими у відносинах між колишніми комуністичними країнами та їх ліберально-демократичними партнерами в ЧМР, якщо виходити виключно 3 концепції конкуренції за виживання. У випадку з Туреччиною, з ії централізованим та глибоко персоналізованим процесом прийняття рішень (що стало ще відчутнішим після переходу до президентської форми правління у 2017 р.), а також розмаїттям культурних та цивілізаційних ідентичностей у суспільстві, конструктивістський підхід дозволяє виявити специфіку зовнішньої політики, обумовленої нормами, правилами та мовою. Курдське питання, роль діаспор у Туреччині, які підтримують ту чи іншу сторону в «заморожених» або гарячих конфліктах регіону (абхази, осетини, черкеси, кримські татари, турки-месхетинці, гагаузи) і суттєво обмежують простір для «маневру» Анкари на міжнародній арені - все це потребує вивчення впливу цінностей на формування зовнішньої політики. 
По-третє, конструктивісти стверджували, що міжнародна політика є далеко не об'єктивною реальністю, а «світом нашого творення» (Onuf, 1989). Конструктивісти запровадили можливість агентності (здатність людини до дії, здатність виступати як самостійний агент і робити усвідомлений і вільний вибір) та взаємодії. Справа не в тому, що актори абсолютно вільні у виборі свого оточення, а в тому, що вони роблять вибір у процесі взаємодії з іншими (Ruggie, 1998; Risse, 2000) i, як результат, створюють історичні, культурні та політичні «реалії». У цьому випадку МВ є соціальною конструкцією, а не незалежною від людського чинника. Якщо MB $є$ конструкцією, грою, то важливим наступним кроком є міркування про правила гри, які можна змінювати (Onuf, 1989; Kratochwil, 1989). Центральні теми змін, соціальності та взаємодії вказують на цінність конструктивізму, важливий крок вперед у дослідженні зовнішньої політики порівняно зі структуралістськими висновками.

Більшість конструктивістів висловлювались критично щодо раціоналізму, але не відмовлялися від нього як наукового методу. Центральними питаннями їх діалогу з раціоналістами стали природа буття (онтологія), взаємозв'язок «структура - агент», роль пізнання.

Раціоналістичні теорії МВ мають індивідуалістичну онтологію, оскільки основною одиницею аналізу є індивід (найчастіше держава). Наприклад, неореалістична теорія розглядає держави так, ніби вони люди, які намагаються вижити. У неолібералів, таких як Джудіт Голдштейн та Роберт Кеохан, ідеї - це причинно-наслідкові фактори, якими обмінюються повністю сформовані актори (Goldstein \& Keohan, 1993). Натомість конструктивісти наголошують на соціальній онтології. Будучи принципово соціальними істотами, держави не можуть бути відокремлені від контексту, який визначає, ким вони є та які можливості їм надаються. Дійсно, поняття суверенітету - це, насамперед, соціальна категорія, оскільки попередньою умовою визнання суверенітету окремих держав є спільне розуміння та прийняття цієї концепції. Джон Сірл стверджував: соціальні факти залежать від згоди людини й потребують людських інституцій, наприклад, без зазначення вартості та існування фінансових установ доларова банкнота чи банкнота євро будуть лише аркушем паперу; інший приклад - кордони, що розділяють держави, існують лише з людської згоди (Searle, 1995, с. 2).

Взаємовідносини «агент - структура» важливі як для раціоналізму, так і для конструктивізму, але сприймаються кожним по-різному. Для раціоналістів структура функціонує через конкуренцію та розподіл матеріальних можливостей. Раціоналісти ж керуються логікою наслідків, тобто раціональний вчинок - це той, який дасть результат, що мак- 
симізує інтерес окремого індивіда. Конструктивісти керуються логікою відповідності (March \& Olson, 1989), тобто раціональний вчинок - це легітимний вчинок, визначений не суто індивідуальними інтересами, а спільними цінностями й нормами в установах чи інших соціальних структурах. Актори намагаються «робити правильно», а не оптимізувати свої переваги (Risse, 2000, с. 4). Права людини є складовою рисою ліберальних демократичних держав, і на міжнародному рівні складовою рисою їх легітимності. Соціальна структура залишає більше простору для агентності - впливу держави на оточення й навпаки.

Заголовок відомої статті Александра Вендта (Wendt, 1992) «Anarchy Is What States Make of It», найкраще виражає цю ідею. Хоча конструктивізм вперше було введено в МВ Ніколасом Онуфом (Onuf, 1989), його основи найчастіше ототожнюються саме $з$ цією статтею А. Вендта. У статті було представлено потенціал агентності за відсутності глобальної влади, в умовах анархії. Критика А. Вендта безпосередньо стосувалася твердження, що державам залишається мало вибору, окрім конкуренції, щоб вижити. А. Вендт надав підставу для роздумів про інтереси як «сконструйовані», так і такі, що піддаються трансформації. Він ставив за мету побудувати міст між двома традиціями, раціоналістичними та рефлективістськими (або позитивістськими та постпозитивістськими), розробляючи конструктивістські аргументи, запозичені з соціології. А. Вендт вважав, що актори «визначають свої інтереси, визначаючи ситуацію». Інституції - це відносно статичні набори / «структури» ідентичностей та інтересів, але мають мотиваційну силу лише за умови соціалізації актора. Необхідно враховувати «інтерсуб'єктно складену структуру ідентичностей та інтересів у системі», взаємодіяти, а не діяти індивідуально. А. Вендт стверджував, що актори мають здатність до вибору. Це може статися, наприклад, за наявності нових соціальних обставин, які неможливо відобразити у старих поняттях. Актори можуть брати участь у «саморефлексії та практиці, спеціально розробленій для трансформації своєї ідентичності та інтересів», та «змінювати ігри», частиною яких вони є. Взаємодії розвиваються з часом й не завжди характеризуються ворожнечею та егоїзмом (Wendt, 1992, с. 404-405).

Американська зовнішня політика не може бути пояснена без урахування змінної «ідентичності». Джон Раггі порівняв політику США щодо Канади, Франції, з одного боку, та щодо Сгипту та Китаю, з іншого. Він пересвідчився, що політика обумовлена не просто питанням безпеки, а спільною ідентичністю з першими та драматично іншою 3 останніми. Дж. Раггі також наголосив, що «інтереси» не $\epsilon$ незмінною категорією; вони є предметом постійної зміни під впливом взаємодії $з$ «іншими» (Brown \& Ainley, 2009, с. 50). 
США та Британія тривалий час часу розвиваються як друзі. Багато держав у сучасному СС - колишні вороги, які навчилися працювати разом. Хоча конструктивісти не заперечують важливість інтересів, вони пов'язують їх з «ідентичністю» актора. Ані ідентичність, ані інтереси не можна відірвати від світу соціального значення. Ідентичність ліберальних демократій не може бути відмежована від інтересу дотримання прав людини. У такому регіоні як ЧМР, де взаємодіють ліберальні та неліберальні актори, причому неліберальні переважають, це додає труднощів у процесі будь-якої галузевої співпраці.

Міркуючи про пізнання, багато реалістів, як і конструктивістів, відштовхувалися від концепції Verstehen (розуміння) Макса Вебера. Різниця полягає у тому, що перші наголошують на індивідуальному, а другі - на соціальному. Однак різниця є не такою й суттєвою; раціональні мислительні процеси «Альтера» та «Его» (Wendt, 1992) передують соціальній взаємодії. Отже, конструктивізм додає соціального виміру, якого не вистачало раціоналістам. Конструктивізм запозичує у позитивістів «причинність» та «гіпотезу», доповнює це «раціональністю індивідів, вбудованою в соціальний контекст».

За Брауном та Ейнлі, «конструктивізм став ярликом, що почав примірятися до науковців, особливо в США, які хотіли отримати певну незалежність від мейнстірмової американської ТМВ, i, разом з тим, зберегти певний рівень респектабельності» (Brown \& Ainley, 2009, с. 48), тож ототожнювали себе 3 серединною позицією між раціоналістичним та постструктуралістським підходами. Браун та Ейнлі вважають, що праці А. Вендта, Ф. Кратохвіла та Н. Онуфа є радикальною альтернативою звичайній ТMB (Brown \& Ainley, 2009, с. 48). Чи це справді так?

І раціоналісти, i конструктивісти стверджують, що їх не розділяють великі відмінності (Wendt, 1998, с. 116; Katzenstein, Keohane \& Krasner, 1998, с. 675). Учені МВ за останні два десятиліття намагаються побудувати діалог між класичним реалізмом та конструктивізмом (SterlingFolker, 2002; Barkin, 2003; Jackson, 2004). Реалізм робить припущення про акторів та про їх діяльність (шукачі влади, які існують у конкурентному середовищі). 3 конструктивістської точки зору треба аналізувати, як конкурентні відносини перетворюються на процеси взаємодії.

Роль мови значно ігнорується в дискусіях між раціоналістами та конструктивістами. Мову розуміють як на «дзеркало об'єктивного світу», як «чисту інтерпретацію», як «норми, заснованої на правилах». 3 точки зору конструктивістів, використання мови $\epsilon$ принципово соціальним. Ми соціалізуємося й розуміємо як діяти у світі: що означає обіцяти, погрожувати, брехати; що означає проголосувати, розгорнути ра- 
кетний комплекс. Використання мови є частиною дії у світі. Без мови ми не могли б надавати значення предметам чи діям, мислити або висловлювати почуття. Підхід до мови як до норм вимагає, щоб ми звернули увагу, яку мову використовують соціальні суб'єкти (Fierke, 2013, с. 96).

Наприклад, домінуючі категорії, що визначали ідентичність у комуністичній Югославії, відрізнялися від тих, що виникли разом 3 конфліктом між сербами, хорватами та мусульманами. Категорія «Югославія» охоплювала всіх під міткою/ідентичністю «південні слов'яни». Навпаки, етнічні категорії стали нормою під час переходу конфлікту в Югославії. Хоча СФРЮ є найяскравішим прикладом, схожі обставини можна знайти й у ЧМР.

Наміри і дії визначаються публічною мовою соціально сформованих акторів. «Наміри» осіб, які займалися етнічними чистками, не можна відокремити від соціального світу, в якому сусіди стали «небезпечними чужинцями», визначеними як «четники», «усташі» або «османи», - мітками з глибоким історичним резонансом, - яких треба усувати як загрозу. Ми не можемо потрапити всередину індивідуальної свідомості, а змагання за виявлення «справжньої» причини чи наміру зазвичай перетворюються на битву інтерпретацій. Питання слід формлювати, акцентуючи увагу на соціальному контексті досліджуваного (Fierke, 2013, c. 197).

Ми можемо порушити питання «як це стало можливим», як Пітер Говард (Howard, 2004) стосовно того, що Ірак фактично становив меншу загрозу для США, ніж Північна Корея, але все ж таки став об'єктом вторгнення. Він простежив, як історична закономірність взаємодії зі США заклала основу для політики «осі зла» щодо цих двох держав. Висловлювання «як це можливо» розкриває важливість мовного питання. Зараз відомо, що розвідувальні організації з обох боків Атлантики помилялися, вважаючи, що в Іраку є зброя масового знищення. Незалежно від того, чи вірили актори розвідданим чи підробляли їх, ця «підстава» зробила вторгнення можливим. Засоби переконання американської громадськості та американських солдатів, що це законний акт уряду, виявились ефективними. Легітимність підстави зміцнила зв'язок політичного дискурсу між Саддамом та нападниками 11-го вересня. Припущення, що Саддам мав зброю масового знищення, хоча і грунтувалося на помилкових даних, створило контекст для виправдання вторгнення. Підстава для вторгнення була артикульована загальнодоступною політичною мовою. Намір вторгнутися було закладено в мовних іграх і в самому акті вторгнення. Отже, відбувся поворот у МВ ставитися до вторгнення як до міжнародної «практики» або до соціально значущої моделі, яка більшменш компетентно виконується (Adler \& Pouliot, 2011). 


\section{Висновки}

У 1990-ті рр. для вчених було звичайною справою проголошувати, що міжнародна політика трансформувалася з закінченням «холодної війни», що світ стає «більш мирним», а реалізм - «мертвим». Економічна глобалізація нібито пов'язала державу; деякі навіть передбачали іiі швидку кончину. Інші стверджували, що західні еліти вперше задумалися про міжнародну політику з точки зору співпраці та сподівань, що глобалізація знань сприяє поширенню нового підходу. Багато хто стверджував, що демократія поширюється всією земною кулею, i, оскільки демократії не борються одна з одною, ми досягли, за Ф. Фукуямою, «кінця історії». Треті стверджували, що міжнародні інститути нарешті здатні спонукати головних акторів діяти відповідно до принципу верховенства закону.

Після 11-го вересня цей оптимізм згас, якщо не зник зовсім, a peaлізм повернувся. Це частково було пов'язано з тим, що майже кожен реаліст виступив проти війни в Іраку, яка перетворилася на стратегічну катастрофу для США. Але, що більш важливо, немає підстав вважати, що глобалізація або міжнародні інститути завдали шкоди державі. Дійсно, у держави, як головного міжнародного актора, є світле майбутнє не лише тому, що націоналізм, який підтримує роль держави, залишається потужною політичною ідеологією. Навіть у Західній Європі, де відбулася безпрецедентна економічна інтеграція, держава живе й процвітає. Крім того, військова міць, як і раніше, є найважливішим елементом світової політики. США та Великобританія, дві великі ліберальні демократії, разом вели п’ять воєн після закінчення «холодної війни». Іран і Північна Корея нагадують нам про те, що поширення ядерної зброї залишається серйозною проблемою, і нескладно сформулювати правдоподібні сценаpiї, за якими Індія та Пакистан опиняються у стані війни з залученням ядерної зброї. Також можливо, хоча і малоймовірно, що Китай і США можуть бути втягнуті до війни (за Тайвань або за Північну Корею). Навіть оптимісти визнають, що Китай може стати серйозною проблемою, пов'язаною зі зміною світової влади. По суті, світ залишається небезпечним місцем, хоча рівень загрози варіюється від місця до місця і час від часу. Держави турбуються про своє виживання, а це означає, що вони не можуть не звертати уваги на баланс сил. Міжнародна політика залишається синонімом силової політики, як і було раніше.

Тому науковцям слід виходити 3 концепції сили й знаходити власні відповіді на питання про те, чому держави прагнуть влади, скільки влади достатньо й коли конкуренція у сфері безпеки може призвести до збройного конфлікту. Роздуми про це необхідні для розробки стратегій, 
єдиного способу, яким держави можуть пом'якшити небезпеку міжнародної анархії.

Справедливим є твердження, що «Війна 3 терором» після 11-го вересня не тільки відродила політичний реалізм, а й надала певним темам «конструктивістського повороту», таким як ідентичність та людські емоції, більшого соціального значення, що виражається у політичних наративах. Джордж Буш (молодший) мав зазначити вагомі причини для своїх зовнішньополітичних дій: так роблять усі сучасні політики. Хоча мова і практика взаємодіють, вони також містять суперечності, які сприяють трансформації контексту. Ці суперечності виявилися в кількох аспектах політики адміністрації Буша. По-перше, практика війни передбачала порушення прав людини, зневагу до міжнародного права та недослухання до висловлювань навіть традиційних союзників, які були проти вторгнення до Іраку. По-друге, заходи призупинення багатьох громадянських свобод в умовах війни були в конфлікті з метою, за яку велася війна, тобто збереження способу життя, визначеного відкритістю та свободою. Спочатку США залучилися підтримкою з боку міжнародної спільноти, 3 часом ця підтримка слабшала, оскільки практика Буша порушувала правила та норми міжнародного права. Сумнівна законність вторгнення до Іраку у 2003 р., інциденти в Гуантанамо, викриття фотографій в'язнів, принижених в Абу-Грейб в Іраку, призвели до серйозної втрати легітимності та питань, чи відступили США від власних основних принципів у спробі подолати загрозу безпеки. Хоча, здавалося, ці практики порушують міжнародні норми й правила, це порушення невдовзі посилило значення норм та правил для визначення належної поведінки в МВ.

Як засвідчи конструктивістський аналіз, людські страждання часто використовуються для закріплення колективної ідентичності та мобілізації військової сили. Щодо цього саме конструктивістський аналіз відкриває простір для більшої рефлексії з обох сторін конфлікту. Це дає можливість акторам відступити й запитати, як їхні дії можуть сприяти створенню проблем, які вони прагнули вирішити.

Таким чином, під час аналізу конкретних кейсів стає зрозуміло, що спільні дослідження реалістів та конструктивістів надають більш об'єктивну картину реальності, ніж вони спроможні зробити це самостійно.

\section{Список посилань}

1. Adler, E., \& Pouliot, V. (Eds.). (2011). International Practices. Cambridge: Cambridge University Press.

2. Barkin, S. (2003). Realist Constructivism. International Studies Review, 5, 325-342. 
3. Brown, C., \& Ainley, K. (2009). Understanding International Relations. Palgrave Macmillan.

4. Brown, C. (2004). Do Great Powers Have Great Responsibilities? Great Powers and Moral Agency. Global Society, 18, 21-42.

5. Brown, M. E., Coté Jr, O. R., Lynn-Jones, S. M., \& Miller, S. E. (2004) (Eds.). Offense, Defense, and War. Cambridge: MIT Press.

6. Buzan, B. (1993). From International System to International Society: Structural Realism and Regime Theory Meet the English School. International Organization, 47, 3, 327-352.

7. Checkel, J. T. (1998). The Constructivist Turn in International Relations Theory. World Politics, 50, 2, 324-348.

8. Copeland, D. C. (2000). The Origins of Major War. Ithaca, NY: Cornell University Press.

9. Dickinson, G. L. (2008). The European Anarchy. Gloucester: Dodo Press.

10. Donelly, J. (2000). Realism and International Relations. Cambridge: Cambridge Univ. Press.

11. Dunne, T. (1995). The Social Construction of International Society. European Journal of International Relations, 1, 367-389.

12. Dunne, T., \& Schmidt, B. (2004). Realism. In Baylis, J., \& Smith, S. (Eds). The Globalization of World Politics, 99-112. Oxford: Oxford University Press.

13. Elman, C. (1996). Horses for Courses: Why Not a Neorealist Theory of Foreign Policy? Security Studies, 6, 7-53.

14. Fearon, D. (1998). Domestic Politics, Foreign Policy, and Theories of International Relations. Annual Reviews of Political Science, I, 289-313.

15. Fierke, K. M. (2013). Constructivism. In Dunne, T., Kurki, M., Smith, S. (Eds.). International Relations Theories. Discipline and Diversity, 187-204. Oxford Univ. Press.

16. Glaser, C. L. (2010). Rational Theory of International Politics: The Logic of Competition and Cooperation. Princeton: Princeton University Press.

17. Goldstein, J., \& Keohane, R. O. (Eds.) (1993). Ideas and Foreign Policy: Beliefs, Institutions, and Political Change. Ithaca, NY: Cornell University Press.

18. Howard, P. (2004). Why Not Invade Korea? Threats, Language Games and US Foreign Policy. International Studies Quarterly, 48/4, 805-828.

19. Huntington, S. (1996). The Clash of Civilizations and the Remaking of World Order. NY: Simon \& Schuster.

20. Jackson, P. T. (Ed.) (2004). Bridging the Gap: Toward a Realist-Constructivist Dialogue. International Studies Review, 6/2, 337-352.

21. Jorgensen, K. E. (2010). International Relations Theories. A New Introduction. Palgrave Macmillan.

22. Katzenstein, P., Keohane, R. O., \& Krasner, S. D. (1998). International Organization and the Study of World Politics. International Organization, 52/4, 645-685.

23. Kratochwil, F. (1989). Rules, Norms and Decisions: On the Conditions of Practical and Legal Reasoning in International Relations and Domestic Affairs. Cambridge: Cambridge University Press. 
24. Liberman, P. (1996). Does Conquest Pay: The Exploitation of the Occupied Industrial Societies? Princeton: Princeton University Press.

25. March, J. G., \& Olson, J. P. (1989). Rediscovering Institutions. New York: Free Press.

26. Mearsheimer, J. J. (2001). The Tragedy of Great Power Politics. New York: Norton.

27. Mearsheimer, J. J., \& Walt, S. (2003). An Unnecessary War. Foreign Policy, $134,50-59$.

28. Mearsheimer, J. J. (2006). Conversations in International Relations, Part I and II. International Relations, 20, 105-125 / 231-245.

29. Mearsheimer, J. J. (2013). Structural Realism. In Dunne, T., Kurki M., Smith S. (Eds.). International Relations Theories. Discipline and Diversity, 77-93. Oxford Univ. Press.

30. Nau, H. R. (2002). At Home Abroad: Identity and Power in American Foreign Policy. Ithaca, L.: Cornell Univ. Press.

31. Onuf, N. (1989). World of Our Making: Rules and Rule in Social Theory and International Relations. Columbia: University of South Carolina Press.

32. Posen, B. R. (1984). The Sources of Military Doctrine. Ithaca, NY: Cornell University Press.

33. Risse, T. (2000). "Let's Argue!": Communicative Action in World Politics. International Organization, 54/1, 1-39.

34. Ruggie, J.G. (1998). What Makes the World Hang Together? Neo-Utilitarianism and the Social Constructivist Challenge. International Organization, 52/4, $855-885$.

35. Schmidt, B. C. (1988). The Political Discourse of Anarchy. Albany: State University of New York Press.

36. Schweller, R., \& Priess, D. (1997). A Tale of Two Realisms: Expanding the Institutions Debate. Mershon International Studies Review, 41, 1-32.

37. Searle, J. R. (1995). The Construction of Social Reality. London: Allen Lane; New York: Free Press.

38. Snyder, J. (1991). Myths of Empire: Domestic Politics and the International Ambition. Ithaca, NY: Cornell University Press.

39. Snyder, G. H. (1997). Alliance Politics. Ithaca, NY: Cornell Univ. Press.

40. Sterling-Folker, J. (2000). Competing Paradigms or Birds of a Feather? Constructivism and Neoliberalism Institutionalism Compared. International Studies Quarterly, 44/1, 97-119.

41. Van Evera, S. (1999). Causes of War: Power and the Roots of Conflict. Ithaca, NY: Cornell University Press.

42. Walt, S. M. (1987). The Origins of Alliances. Ithaca, NY: Cornell University Press).

43. Waltz, K. N. (1979). Theory of International Politics. Reading: AddisonWesley.

44. Waltz, K. N. (2001). Man, the State, and War: A Theoretical Analysis. Columbia: Columbia University Press.

45. Wendt, A. (1992). Anarchy is What States Make of It: The Social Construction of Power Politics. International Organization, 46/2, 391-425. 
46. Wendt, A. (1998). Constitution and Causation in International Relations. Review of International Studies, 24/5, 101-117.

47. Wendt, A. (1999). Social Theory of International Politics. Cambridge \& New York: Cambridge University Press.

48. Wohlforth, W. C. (1999). The Stability of a Unipolar World. International Security, 24/1, 5-41. 


\section{РОЗДІЛ 2}

\section{ПОЛІТИКА ТУРЕЧЧИНИ У ЧОРНОМОРСЬКОМУ РЕГІОНІ: БАЛАНС СИЛ, ЗАГРОЗ ТА ІНТЕРЕСІВ}

(Габер $\boldsymbol{\epsilon}$. В.)

\section{Bcmyn}

Турецька Республіка (ТР) займає унікальну позицію в Чорноморському регіоні. Країна - член НАТО з другою після США армією в Альянсі, активно розвиває військово-політичне співробітництво з Російською Федерацією. Впливовий регіональний гравець у Чорному морі, Анкара має життєво важливі інтереси у сфері безпеки на Близькому Сході, реалізує амбітні економічні та енергетичні проекти у Східному Середземномор'ї, використовує спільну історичну і культурну спадщину, як важливий інструмент у відносинах з країнами та народами Кавказу і Центральної Азії.

Ця мультирегіональна ідентичність дає Туреччині додаткові важелі впливу на широкому геополітичному просторі від Балкан до західного Китаю. Водночас, разом зі значними перевагами, Анкара постає перед складними дилемами безпеки, які не тільки суттєво впливають на формування iï зовнішньої та безпекової політики, але й часто виступають каталізатором внутрішньополітичних процесів.

3 одного боку, починаючи ще з часів російсько-османських війн, басейн Чорного моря декілька століть поспіль залишався ареною постійної боротьби між двома регіональними державами. Одночасно «російсько-турецьке озеро» завжди розглядалося в обох столицях як виключна зона власних інтересів, і жодна 3 них не допускала втручання в регіон зовнішніх чинників.

У часи «холодної» війни Туреччина знов опинилася з Росією по різні сторони «залізної завіси», виступаючи важливим південно-східним форпостом НАТО для стримування СРСР у регіоні. Втім, і відносини зі Сполученими Штатами в цей час розвивалися радше під впливом структурних обмежень біполярної міжнародної системи, ніж «за вільним волевиявленням» сторін (варто згадати хоча б Кіпрську кризу 1974 р., яка ледь не призвела до розриву стосунків між союзниками).

У 1990-ті роки Анкара спробувала відійти від історичної дихотомії НАТО - РФ та заявити про свої амбіції регіонального лідера за рахунок активного розвитку двосторонніх відносин та багатосторонніх ініціатив з новими незалежними республіками, що утворилися після розпаду СРСР. Зокрема, у травні 1992 р. було підписано Договір про дружбу і 
співробітництво між Україною і ТР, який закладав основу сучасних українсько-турецьких відносин. Важливою складовою регіональної політики ТР в цей час стають багатосторонні інтеграційні проекти, на кшталт створеної у 1992 р. Організації Чорноморського Економічного Співробітництва зі штаб-квартирою у Стамбулі.

Втім, вже швидко стало зрозуміло, що подібні формати неспроможні забезпечити ні регіональну стабільність, ні національну безпеку. Відтак, у подальші роки визначальним фактором політики Туреччини в Чорноморському регіоні була співпраця з глобальними гравцями (США та НАТО, з одного боку, і Росією, з іншого). Наприклад, коли у 1994 р. було запроваджено програму НАТО «Партнерство заради миру», Туреччина з готовністю виступила своєрідним «представником» Альянсу у відносинах з регіональними країнами (зокрема, Україною та Грузією), оскільки це сприяло укріпленню іiї власного статусу в регіоні. 3 іншого боку, не дивлячись на членство в Альянсі з 1952 р., Анкара традиційно намагалася утримуватися від участі в будь-яких ініціативах, що могли ускладнити іiї відносини з Москвою.

Метою цього дослідження $є$ аналіз сучасної політики Туреччини в Чорноморському регіоні через призму теорій структурного реалізму та конструктивізму, виявлення ключових чинників регіональної політики та окреслення можливих сценаріїв на середньострокову перспективу.

\section{Теоретичні засади вивчення регіональної політики ТP}

Головний спосіб вирівнювання сил всередині системи неореалісти вбачають у підтримуванні балансу сил, хоча й розглядають його крізь призму структурного впливу. На думку основоположника цього напряму ТМВ Кеннета Уолца, політика балансу сил має визначальне значення при формуванні союзів держав, адже саме до цього їх спонукає анархічне міжнародне оточення. Структурні зрушення, зміни в балансі сил можуть відбуватися й надалі, але жодна перестановка в конфігурації військових сил не здатна змінити базової структури світової системи чи радикально модифікувати поведінку іiї суверенних частин. Це означає, що «не сам колись досягнутий баланс сил буде зберігатися, а одного разу порушений баланс буде відновлюватися» (Waltz, 1979, с. 128).

Також Стівен Уолт запропонував свою концепцію балансу загроз, в якій він дещо модифікував учення Уолца, змістивши головну увагу $з$ рівня наявної сили на рівень можливих загроз. Зокрема, Уолт доводив, що головною мотивацією держав при формуванні союзів є не стільки прагнення врівноважити реальні сили, скільки намагання вберегти себе від потенційних загроз. А оскільки загрози, як правило, надходять від наймогутнішого центру сили, то держави, скоріш за все, будуть намага- 
тися нейтралізувати джерело небезпеки, аніж об'єднуватися з ним (Walt, 1985, с. 15). Враховуючи, що наразі понад 80 \% турків вважають США основним джерелом загроз для національної безпеки ТР (Turkish Foreign Policy, 2019), цілком зрозуміло, чому керівництво країни прагне знайти альтернативних союзників для створення противаги американській присутності в регіоні.

Розвиваючи ідеї попередників, інший неореаліст Гленн Снайдер зазначав, що навіть в умовах «біполярної глобальної системи» Уолт розглядав поведінку держав у рамках «багатополярних регіональних систем», що існували як iï автономні частини (Snyder, 1997, с. 266). Сучасні дослідники також зазначають, що важливою рисою балансування в постбіполярному світі $\epsilon$ його регіональний характер. На думку Стівена Брукса і Уільяма Уолфорта, «політика, навіть якщо це міжнародна, завжди локальна. Тож, хоча американська могутність і привертає до себе багато уваги на глобальному рівні, держави, зазвичай, набагато більше переймаються розвитком подій в їх безпосередньому оточенні, аніж підтриманням глобальної рівноваги. Тому, якби якась із держав мала потенційне бажання кинути виклик США, в першу чергу були б залучені механізми регіонального балансування...» (Brooks \& Wohlforth, 2002, c. 24).

До того ж, балансування проти глобальної сили вимагає значних витрат, а тому воно доступне дуже обмеженому колу гравців. Тому, через недостатність ресурсів та важелів впливу для класичного балансування в рамках всієї світової системи, багато держав обирають стратегію підтримання рівноваги на місцевому, регіональному рівні. Зазвичай, подібні моделі поведінки характерні для зовнішньої політики тих держав, що не можуть протистояти могутності Сполучених Штатів у світовому масштабі, проте мають амбіції регіональних лідерів. На певному етапі це призводить до неминучого зіткнення національних інтересів регіональних держав (до яких слід віднести й Туреччину) з інтересами США, або ж, в разі їхнього членства в НАТО, до несумісності їхніх національних інтересів з блоковими зобов'язаннями.

Водночас, хоч деякі країни й намагаються нівелювати вплив США, багато 3 них хочуть отримати від нього свої вигоди - фінансову та військову допомогу, дипломатичну підтримку тощо. Крім того, кожна велика регіональна держава зацікавлена у забезпеченні підтримки Вашингтона на випадок конфлікту з іншими країнами регіону. Враховуючи всі ці переваги, які можуть забезпечити Сполучені Штати, для багатьох регіональних держав може бути набагато доцільнішим об'єднуватися навколо США, а не проти них (Huntington, 1999, с. 45-46). 
Подібні міркування висловлював ще раніше й Рандалл Швеллер, який запропонував концепцію балансу інтересів як альтернативу концепції балансу загроз Уолта. Зважаючи на припущення, що держави будуть намагатися об'єднати свої зусилля за принципом наявності спільних інтересів, аби ефективно протидіяти іншим країнам 3 несхожими інтересами, він пояснював бажання багатьох другорядних сил вступити в союз з наддержавою саме з метою забезпечення своїх цілей за рахунок лідера світової системи (Schweller, 1994).

Крістофер Лейн запропонував таке пояснення поведінки «приєднання до глобального лідера» («band-wagoning with a global leader»). 3a його словами, це відбувається тому, що балансування проти фактичного гегемона набагато складніше за балансування проти нової глобальної сили, що тільки зароджується (Layne, 2006, с. 29). Уільям Уолфорт також зазначає, що створення антигегемонічних союзів («соunterhegemonic alliances») вимагає набагато більше зусиль, аніж формування будь-яких інших міждержавних коаліцій, адже завжди існує спокуса скористатися перевагами, які може запропонувати лише наддержава. Зокрема, приєднання до сильнішої сторони приваблює можливістю позбутися значної долі відповідальності за власні дії на міжнародній арені, а також гарантувати високий рівень національної безпеки (Wohlforth, 1999, с. 29).

За твердженням Джона Міршаймера, ідейного послідовника Кеннета Уолца, «фактично єдиний вибір, що постає перед державами у світі реалістів, стоїть між балансуванням («balancing») за власний кошт i приєднанням до сильнішої держави, на яку перекладається значна частина обов’язків і відповідальності («buck-passing»)». Тож він припускає, що більшість держав будуть віддавати перевагу другій моделі поведінки кожного разу, коли буде виникати реальна загроза їхній безпеці (Mearsheimer, 2001, c. 140). Такої ж думки дотримувався і Джек Снайдер (Snyder, 1990). Зі свого боку Уільям Уолфорт стверджував, що очевидна перевага в силі Сполучених Штатів, що встановилася після закінчення «холодної» війни, призвела до того, що слабші країни були змушені об'єднуватися навколо США як єдиного потужного центра сили в новій системі (Wohlforth, 1999, с. 8).

Відповідно, неореалістичні концепції міжнародних відносин умовно можна розділити на дві великі групи: 1) ті, що базуються на принципі балансування («балансу сил», «балансу загроз», «балансу інтересів»); 2) ті, що засновані на ідеї «приєднання до сильнішої держави» («bandwagoning»), тяжіючи, таким чином, до неоліберальної теорії гегемонічної стабільності.

Відповідно до цієї логіки, автори концепцій, зазначених вище, пропонують для регіональних держав два принципово різні стилі по- 
ведінки на міжнародній арені. Прихильники концепції «приєднання до глобального лідера» прогнозують, що всі слабші держави будуть приєднуватися до явного лідера системи задля максимізації своїх зисків, тобто в умовах постбіполярного світу - об'єднуватися навколо домінуючих на глобальному рівні Сполучених Штатів («global band-wagoning»). Натомість прибічники концепції «балансування» стверджують, що регіональні держави будуть і надалі намагатися створювати коаліції, які б могли урівноважити вплив наддержави хоча б в окремих регіонах світу («regional balancing»).

Хоча між цими напрямами неореалізму ведеться тривала дискусія, досвід Туреччини доводить, що обидві концепції можна вдало поєднувати в зовнішній політиці однієї держави. Саме цю стратегію обрала для себе офіційна Анкара, проводячи, за висловом Деніела Уайтнека, політику «приєднання до сильнішої держави в довгостроковій перспективі та короткочасного балансування проти неї» для вирішення нагальних питань (Whiteneck, 2001).

На глобальному рівні Туреччина виступає як довгостроковий стратегічний партнер Вашингтона - бере участь у глобальних антитерористичних коаліціях, працює в рамках НАТО і двосторонніх договорів, адже їй, як і будь-якій іншій державі світу, на цьому етапі не вистачить ані матеріальних, ані дипломатичних ресурсів протидіяти США. Проте на регіональному рівні, у тих випадках, коли Сполучені Штати не володіють достатніми важелями впливу в регіоні аби діяти без підтримки партнерів «на місці», а національні інтереси Анкари вимагають поглиблення співпраці з регіональними гравцями, Туреччина часто виступає автором амбітних регіональних ініціатив, покликаних вирішити проблеми регіону «силами регіону», без участі гравців, сторонніх регіональній системі. Як зазначає Джошуа Уолкер, незважаючи на те, що «довгострокові інтереси Туреччини в регіоні та поза його межами тісно пов'язані 3 США», Анкара дедалі більше зусиль докладає для зміцнення відносин 3 регіональними гравцями, доволі успішно «підтримуючи хиткий баланс» між двома напрямами своєї зовнішньої політики (Walker, 2008, с. 106).

Отже, теорія структурного реалізму добре пояснює системні стимули та обмежувачі, що визначають об'єктивні умови формування турецької зовнішньої політики в Чорноморському регіоні. Після закінчення «холодної війни» рівень системної напруженості став значно нижчим, дія структурних обмежувачів на формування зовнішньої політики регіональними державами послабшала, відтак Анкара отримала більше можливостей проводити різноманітну, багатовекторну політику, часто всупереч інтересам США. За логікою неореалістів, головним мотивом Туреччини, як і будь-якої іншої регіональної держави, стає прагнення 
врівноважити сили наймогутнішої держави (США) шляхом об'єднання сил з іншими учасниками системи (насамперед, Росією). 3 іншого боку, співпраця з глобальними гравцями в регіоні буде вигідна Анкарі лише 3 тих питань, де їхні інтереси повністю збігаються.

Водночас, розглядати дії Анкари в Чорноморському регіоні виключно в категоріях неореалізму було б суттєвим спрощенням. Хоча держави й альянси дійсно керуються системною логікою (фактично роблять те, що їм «дозволяє» на сьогодні робити структура світової системи), їхня політика приймає конкретні форми, які є продуктом суб 'єктивних рішень державних лідерів та взаємодї численних гравців 3 різним історичним, соціальним, релігійним, культурним та ідеологічним корінням.

Зокрема, важливим питанням, яке дозволяє дослідити конструктивізм, $є$ вплив історичних травм та колективної пам'яті нації на формування іiї стратегічної культури. Як зазначає Дуглас Бекер у праці «Пам’ять та травма як елементи ідентичності при формуванні зовнішньої політики» саме поєднання структурного реалізму та конструктивізму забезпечує оптимальний інструментарій для дослідження цих категорій (Becker, 2014, с. 57). Переваги конструктивістської методології в цьому сенсі відзначав і теоретик конструктивізму Тед Хопф: «Тоді, як для неореалізму всі гравці глобальної політики мають тільки одну виразну ідентичність - ідентичність держави, що керується власними інтересами, конструктивізм розглядає ідентичність як емпіричне питання, що концептуалізується в історичному контексті» (Hopf, 1998, с. 178).

У ситуації з Туреччиною, з її централізованим та глибоко персоналізованим процесом прийняття рішень, розмаїттям культурних та цивілізаційних ідентичностей у суспільстві, а також складною історичною спадщиною, конструктивістський підхід дозволяє заповнити ці методологічні прогалини.

\section{Історичні засади чорноморської політики Туреччини}

На формування стратегічного мислення турецької політичної та військової еліти щодо Чорноморського регіону суттєво плинули дві історичні травми в колективній пам'яті турецького народу. 3 одного боку, це нищівні поразки Османської імперії в російсько-османських війнах за домінування в басейні Чорного моря. Впродовж XVIII-XX ст. Османська імперія 12 разів воювала з Росією - найбільша кількість воєн, проведених проти одного суперника за всю історію імперії. Більшість із них закінчилися значними втратами для Стамбула, породивши міф про «велику Росію». Ідея того, що інтереси Росії повинні бути «враховані за будь-яких обставин», а співпраця з Москвою є обов'язковою умовою ви- 
живання кожної регіональної країни в цій частині світу й сьогодні лунає лейтмотивом у фразі турецьких очільників «ми не можемо дозволити собі розкоші не працювати з Росією».

3 іншого боку, з роками не втратив сили і так званий «Севрський синдром», який отримав свою назву за однойменним мирним договором 1920 р. Цей договір фактично поклав край існуванню Османської імперії, розподіливши іiі території між переможцями війни - країнами Антанти.

Хоча після підписання Севрського миру минуло майже століття, ця глибоко вкорінена недовіра Туреччини до західних країн та одвічна загроза «бути зрадженими й поставленими на коліна Заходом» все ще визначає політичну риторику націоналістичних та консервативних партій TP, зокрема, і провладної коаліції. У багатьох випадках ці настрої підкріплюються антиамериканськими, антизахідними та націоналістичними почуттями, що панують у турецькому суспільстві й знаходять підтримку в концепціях євразійства, активно пропагованих Кремлем. Ці тенденції лише посилилися після того, як прихильники тіснішої співпраці з Росією набули більшого бюрократичного впливу в МЗС та ЗС Туреччини після спроби державного перевороту 2016 року і масових звільнень в лавах «атлантистів» (Flanagan \& Larrabee, 2020, с. хіх).

Ці історичні та психологічні травми у відносинах як з РФ, так і 3 країнами Заходу, в поєднанні з геополітичними реаліями сьогодення, призвели до формування сприйняття Чорного моря в категоріях гри 3 нульовою сумою. Відтак, основною метою Анкари стає збереження статус-кво та підтримання балансу сил у регіоні, аби не допустити перетворення Чорного моря ані на «російське озеро», ані на «подвір'я НАТО». Задля досягнення цієї мети, багатостороння регіональна дипломатія стає важливим інструментом Анкари для забезпечення стабільності та реалізації амбітних цілей регіонального лідерства.

Баланс сил: між «російським озером» та «подвір'ям НАТО»

Після закінчення «холодної війни» та розпаду СРСР інтереси Туреччини в Чорноморському регіоні визначалися, з одного боку, прагненнями регіонального лідерства, а з іншого - необхідністю стримування регіональних амбіцій Росії. ОЧЕС, перша інтеграційна ініціатива, запропонована Анкарою, була спрямована на сприяння розвитку політичного діалогу та економічного співробітництва між 12 країнами-членами, серед яких лише шість були власне прибережними державами. Інклюзивна концепція конструювання «Чорноморського простору» від Кавказу до Балкан, що включала всі прибережні держави, а також Молдову, Вiрменію, Азербайджан, Грецію, Албанію (а згодом - і Сербію), дозволяла 
Анкарі претендувати на провідну роль у набагато ширшій та складнішій регіональній архітектурі.

Експерти зазначають, що подібне довільне групування абсолютно різних держав у межах єдиної регіональної організації вказує на відсутність у зовнішньополітичному мисленні Туреччини бачення Чорноморського регіону як єдиного цілого (Petriashvili, 2015). Цитуючи Д. Лінча, стає зрозуміло, що «кожного разу, коли погляд регіональних важковаговиків, таких як Росія та Туреччина, спрямовувався на регіон, їхня мета полягала в тому, аби зробити його частиною власної сфери впливу» (Lynch, 2003, с. 10), аніж розвивати спільну регіональну ідентичність чи просувати дух регіональної співпраці.

Фактично, багатостороння платформа ОЧЕС стала першим кроком на шляху до створення автономної регіональної системи міжнародних відносин з лідером ТР. Це дозволило Туреччині досягти двоєдиної мети. 3 одного боку, залишаючись важливим членом НАТО й союзником США, Анкара отримала значні важелі для балансування зростаючого впливу Росії в регіоні. 3 іншого боку, принцип «вирішення регіональних проблем силами регіональних країн», запропонований Туреччиною та підтриманий Росією, був покликаний не допустити «інтернаціоналізації» басейну Чорного моря, його «мілітаризації» і завадити більш широкій присутності НАТО й інших глобальних гравців у регіоні.

Історично одним з головних завдань Туреччини в регіоні залишалося «недопущення перетворення Чорного моря на новий центр глобального суперництва і конфлікту» між Заходом і Росією. Відповідно до цього, будь-яке розширення військово-морської діяльності НАТО поза межами вже існуючих ініціатив розглядалося Анкарою як небезпечна спроба змінити статус-кво i, таким чином, дестабілізувати регіон (Celikpala, 2010, c. 289).

Турецькі політологи зазначають, що «позиція Туреччини в Чорному морі традиційно грунтується на захисті статус-кво, і країна виступає проти втручання сторонніх держав, фактично створюючи турецько-російський кондомініум у Чорному морі. Відтак, суворе дотримання Конвенції Монтре 1936 р., яка регулює проходження військово-морських кораблів від Середземного моря до Чорного через протоки Босфор і Дарданелли, залишається основою турецької політики» (Devlen, 2014, с. 2).

Коли у 2006 р. Вашингтон виступив із пропозицією розширити операцію НАТО «Активні зусилля» із Середземного моря на Чорне, Туреччина і Росія виступили категорично проти. Обидві країни заявили, що активна участь США дестабілізує регіон, а присутність військових кораблів НАТО в Чорному морі суперечитиме Конвенції Монтре. Крім 
того, на думку ТР, операція дублювала б завдання «Чорноморської гармонії» (турецької національної операції з патрулювання басейну Чорного моря, яка згодом була розширена до участі всіх прибережних держав), а також BLACKSEAFOR - ще однієї регіональної ініціативи Туреччини (Winrow, 2007, с. 130-131). Втім, на Заході спільний протест Москви та Анкари викликав звинувачення в тому, що Туреччина й Росія прагнуть створити в Чорному морі «свій закритий кондомініум» (Socor, 2005).

Хоча турецька влада традиційно наголошувала на готовності співпраці в межах всіх можливих багатосторонніх платформ задля миру та стабільності в регіоні, Анкара завжди рішуче виступала проти будьяких спроб глобальних гравців відігравати активну роль у регіоні. Як зазначав аналітик турецького центру TEPAV, «у більшості з регіональних ініціатив Туреччина обережно працювала лише з країнами регіону ... адже прагнула створити інституційну базу, яка сприяла б закріпленню iii регіонального лідерства. Ініціативи західних союзників не лише підривали законність такої регіональної дипломатії, але й зменшували роль Туреччини в ній (Koru, 2017).

Після накладання вето на розширення операції НАТО «Активні зусилля» в Чорноморському басейні, тенденція «відмовляти в доступі» до регіону для зовнішніх гравців стала ще більш очевидною під час російсько-грузинської війни 2008 р. Тоді між Анкарою та Вашингтоном спалахнув дипломатичний скандал через відмову ТР надати дозвіл на проходження американських кораблів, що перевозили гуманітарну допомогу Грузії. Офіційно приводом для відмови було названо порушення вимог Конвенції Монтре, але реальною причиною стали побоювання негативної реакції з боку РФ.

Водночас тодішній прем'єр-міністр ТР Р. Т. Ердоган запропонував ідею створення «Кавказької платформи стабільності та співробітництва». Ця регіональна організація мала об'єднати п'ять регіональних держав (Туреччину, Росію, Вірменію, Грузію, Азербайджан) з метою врегулювання конфлікту. Тодішній МЗС Туреччини Алі Бабаджан пояснював це так: «кавказьким країнам потрібно розробити функціональний спосіб вирішення своїх проблем зсередини», а не чекати допомоги ззовні (Babacan, 2008).

Політика ТР здебільшого визначалася зазначеною вище концепцією «регіональних рішень для регіональних проблем» і після 2008 р. Вона мала сприяти посиленню ролі Анкари як незалежного гравця, що відіграє провідну роль в регіональних процесах, і звести до мінімуму військову, а часом і дипломатичну присутність західних партнерів у регіоні. 
Усвідомлюючи занепокоєння Туреччини через можливу втрату домінуючої позиції в басейні Чорного моря на тлі зростаючої присутності США, експерти американського «Heritage Foundation» ще в 2006 р. оприлюднили рекомендації створити «тристоронній канал для обміну та консультацій між Болгарією, Румунією і ТР», щоб зменшити безпекові ризики для Анкари, сприяти подальшій співпраці за допомогою інформаційного обміну та у спільних військово-морських операціях (Cohen \& Conway, 2006). Однак, коли в 2016 р. президент Румунії виступив з ініціативою так званої «Чорноморської флотилії», яка повинна була включати румунські, болгарські, турецькі та, можливо, українські військово-морські сили з метою розвитку взаємодії між підрозділами та проведення в iii рамках спільних військово-морських навчань, Анкара розкритикувала ідею за те, що вона викликала непотрібну напругу в регіоні, провокуючи подальшу ескалацію з Росією та дублювання вже існуючих форматів військово-морського співробітництва НАТО (Tol, 2019).

Варто зазначити, що ця ідея отримала нетривалу підтримку Анкари після кризи зі збитим російським літаком у 2015-2016 рр. Зіткнувшись $з$ реальною загрозою відкритого протистояння з Росією, Ердоган чи не вперше відкрито визнав, що НАТО «фактично відсутнє у Чорному морі»: «Чорне море стало майже російським озером. Якщо ми не будемо діяти зараз, історія нам цього не пробачить» (Flanagan, 2020, с. 126). Тож коли на Варшавському саміті 2016 р. союзники домовились про забезпечення посиленої передової присутності НАТО в регіоні, Анкара погодилася брати участь у багатонаціональній бригаді Румунії під прапором НАТО, це мало стати відповіддю на провокативні дії Росії в басейні Чорного моря. Але після швидкого відновлення діалогу з Росією Анкара фактично звела нанівець всі домовленості щодо участі в цій ініціативі (Toucas, 2018).

Баланс загроз: конкуруючі пріоритети безпеки в Чорному морі та на Близькому Сході

Російська агресія в Україні та незаконна анексія Криму призвели до кардинальної зміни безпекової ситуації в Чорному морі. Більшість нових загроз, що виникли після 2014 року, стосувалися не тільки самої України, але й Туреччини. Мілітаризація регіону внаслідок нарощування російської військової присутності в басейні Чорного моря; мілітаризація та нуклеаризація окупованого Кримського півострова; посилена військова модернізація Росії, зокрема, випробовування нових видів стратегічної зброї, розбудова сучасного флоту підводних човнів, широке застосування засобів РЕБ; розміщення стратегічного озброєння в Криму 3 можливістю його подальшого використання як плацдарму для проекції 
російської військової сили в Чорному морі та Середземномор'ї; нарешті, загроза значного погіршення гуманітарної ситуації на окупованому півострові, порушення прав спорідненої тюркської групи кримських татар та дії Росії, спрямовані на зміну демографічної ситуації в Криму, лише деякі приклади новітніх загроз, які тільки посилилися за останні роки. Не менш важливою складовою є і подальше нарощування військово-морського флоту РФ, який вперше після розпаду СРСР почав викликати занепокоєння в турецьких ВМС.

Як зазначає аналітик «Atlantic Council», за цей час «Москві вдалося створити потужні об'єднані сили з сухопутними, морськими, повітряними компонентами та сучасними засобами радіоелектронної боротьби, завдяки яким вона була б цілком здатна заборонити доступ до регіону Чорного моря силам НАТО в разі виникнення конфлікту» (Blank, 2016). Якщо додати до цього розбудову російської системи засобів заборони доступу (A2/AD - anti-access and area denial - обмеження та заборона доступу), військове стримування супротивника через створення «захищеної зони» із застосуванням ракетних систем ППО, протикорабельних ракетних систем тощо) у східному Середземномор'ї та на Кавказі, а також військову присутність РФ у Криму, на сході України, в Сирії, Вірменії та Абхазії, то Туреччина фактично опиняється в оточенні російських військ з півночі, півдня та сходу.

За словами військових експертів, російські чорноморські та сирійські «бульбашки A2/AD» мають значення для Туреччини з кількох причин. По-перше, «вони означають кінець відносної морської переваги, яку Анкара встановила в Чорному та Егейському морях і Східному Середземномор'ї після «холодної» війни. По-друге, вони вказують на те, що «Туреччині доведеться перенаправляти значні ресурси від амбітного нарощування власних сил в Середземному морі на розробку стратегій та зброї для протидії російській військовій присутності» в регіоні, в безпосередній близькості до турецьких кордонів. До того ж, експерти зазначають, що «хоча наразі російсько-турецькі відносини мають вигляд добросусідських, їх майбутнє не визначене - і якщо вибухне криза, подібна до інциденту зі збиттям російського Су-24 у листопаді 2015 р., то Анкара може зіткнутися з жахливими наслідками» (Kurtdarcan \& Kayaoglu, 2017).

Все це мало б змусити турецьке керівництво посилити заходи зі стримування РФ, зокрема, і шляхом посилення співпраці з партнерами по НАТО. Однак всупереч сподіванням, що Туреччина стане ключовим провайдером безпеки в регіоні і як член НАТО, і як єдина сила, здатна стримувати зростаючу військову присутність Росії, цього не сталося. 
По-перше, це пов'язано зі значним погіршенням безпекової ситуації в інших регіонах (зокрема, Близького Сходу та Егейського моря), які, на відміну від Криму та «заморожених» конфліктів в країнах ГУАМ, часто становлять екзистенційну загрозу для Туреччини. Опитування університету Кадір Хас за 2020 р. завідчило, що Чорноморський регіон не належить навіть до першої п'ятірки турецьких пріоритетів у сфері безпеки. Натомість, на думку респондентів, головна загроза пов'язана з ескалацією в Сирії, Лівії та Східному Середземномор'ї, гуманітарною і дипломатичною кризою навколо біженців та тероризмом (головним чином, курдських PKK та YPG), що діють, на переконання більшості турків, за підтримки США (Türkiye Eğilimleri, 2020). До речі, саме США (стратегічного партнера та союзника ТР по НАТО) більшість громадян багато років поспіль називають головною загрозою національної безпеки (81,3 \% у 2019 р.), залишаючи далеко позаду «одвічних суперників»: Росію, Сирію, Вірменію та Кіпр (Research on Public Perceptions, 2019).

У цьому сенсі показовими були заяви президента Ердогана на Лондонському саміті НАТО 2019 р. Його погрози заблокувати плани оборони Альянсу для Польщі та країн Балтії в разі невизнання курдських угруповань YPG терористичною організацією, чітко продемонстрували, що для Туреччини «проблема східних кордонів НАТО» проходить не Балтійським та Чорним морем, а турецьким кордоном з Сирією. I саме цей регіон залишається для Анкари ключовим пріоритетом у сфері безпеки (Turkey Threatens, 2019).

По-друге, в Анкарі присутні традиційні побоювання, що розбудова військових спроможностей НАТО поблизу російських кордонів може спровокувати небажану ескалацію з боку Москви. Водночас в ТР досі панують очікування, що політика «умиротворення агресора» і постійний «конструктивний діалог» з Кремлем допоможуть забезпечити мир. Тож, хоч Анкара не визнала незаконну анексію Криму й неодноразово виступала на захист територіальної цілісності України, вона завжди уникала безпосереднього згадування про російську агресію в регіоні.

Цим же бажанням «не дратувати російського ведмедя» пояснюється і дуже стримана реакція Туреччини на «Керченський інцидент» у 2018 р. Після того, як Росія захопила три українські судна і взяла в заручники 24 українських моряків, МЗС ТР оприлюднило заяву, в якій «наголошувало на важливості свободи судноплавства через Керченську протоку» та «закликало всі сторони утримуватися від дій, які можуть загрожувати регіональному миру та стабільності» (Press Release, 2018).

Частиною цієї політики «інклюзивного діалогу» стали й заклики до офіційного Києва сісти за стіл переговорів 3 Москвою 
(Yalçınlıkl1, 2017) та відновити участь в операції «Чорноморська гармонія» та BLACKSEAFOR, яка була призупинена після 2014 р. Аналітик «Jamestown Foundation» В. Сокор назвав такий підхід «позицією, що заперечує реальність», зазначаючи, що Анкара «чіпляється за статус-кво, якого вже не існує»: «Туреччини більше немає i, покладаючись лише на власні сили, не може бути противагою загрозливій силі Росії. Але вона також не готова активізувати співпрацю зі своїми чорноморськими та нечорноморськими союзниками по НАТО для того, щоб реагувати на цей зростаючий виклик» (Socor, 2018).

Ця «дивна» поведінка офіційної Анкари є цілком логічною з точки зору теорії балансу загроз: в нинішній ситуації саме США сприймаються в Туреччині як головне джерело потенційних загроз у регіоні. Тоді як об'єднання сил навколо РФ - хай навіть і в короткостроковій перспективі - може забезпечити відчутніші переваги, ніж гра проти неї.

У Туреччині «мати Росію на борту» розглядають як ключовий фактор стабільності не тільки у Чорному морі, але й на Близькому Сході. Тому слід очікувати, що будь-які кроки Анкари в Чорноморському регіоні будуть підпорядковані більш пріоритетним напрямам. Вагомим чинником залишається й курдське питання, яке для турецької держави вже давно перейшло з розряду зовнішньої політики в питання національної безпеки екзистенційного порядку й вимагає продовження співпраці з Росією.

Відповідно, існування більших загроз в інших регіонах, нейтралізація яких неможлива без безпосередньої участі Москви, обумовила доволі стриману реакцію Анкари на російську агресію в Чорному морі. Прагнення підтримувати «дружні відносини» з Кремлем, підкріплене історичним «комплексом переможеного» лише посилилося на тлі нарощування російської присутності у Східному Середземномор'ї, Сирії та Лівії.

Баланс інтересів: прагматизм в основі зовнішньої політики

Важливу роль у продовженні балансування Анкари між Заходом i РФ відіграла і наявність певної кількості спільних турецько-російських проектів у стратегічних сферах оборонної промисловості, ядерної енергетики та ВПК. Період після придушення спроби державного перевороту в Туреччині у 2016 р. (який, на переконання керівництва країни, було організовано не без допомоги Білого Дому й подолано не без підтримки Кремля) було відзначено безпрецедентним зближенням Анкари з Москвою. В цей час, зокрема, відбувалася активізація співпраці зі стратегічно важливих питань, включаючи зусилля з врегулювання ситуації в Сирії, закупівлю Туреччиною російських систем протиповітряної обо- 
рони S-400 (що призвело до іï вилучення з натівської програми F-35), розвиток співробітництва в економіці, туристичній сфері та енергетиці, запуск газогону Турецький потік, будівництво АЕС Аккую поблизу Мерсіну зусиллями Росатому та спільні проекти в ОПК. Не дивно, що зовнішня політика Туреччини здебільшого була продиктована прагненням уникати будь-яких дій, які могли б загрожувати реалізації цих планів.

Провладна партія Справедливості та розвитку зробила прагматизм головним принципом турецької зовнішньої політики, і їі чорноморський вимір - чи не найкраща демонстрація цього (Mikhelidze, 2017).

Значну роль у російсько-турецьких відносинах відіграють і фактори нижчого порядку, які, зазвичай, ігнорують неореалісти, зосереджені на системному та державному рівнях аналізу. Персональні стосунки й подібний стиль правління Р. Ердогана і В. Путіна, «спрощена» система прийняття рішень в умовах сильної вертикалі влади, не обтяжена бюрократичними погоджувальними процедурами на відміну від західних демократій, близькі ідеологічні засади зовнішньої політики (євразійство, антиамериканізм, історичне сприйняття Чорного моря як внутрішнього моря двох імперій) - всі ці чинники значно сприяли формуванню спільних інтересів двох регіональних лідерів, що мають свій, відмінний від євроатлантичного, порядок денний.

3 іншого боку, не слід переоцінювати й рівень довіри, що існує у відносинах Туреччини з Росією. Історична спадщина нагадує про десятки прикладів зради Московії в минулому, а протилежні інтереси в Сирії, Лівії, Криму та «заморожених» конфліктах регіону (Нагорний Карабах, Абхазія, Південна Осетія) змушують Анкару диверсифікувати зовнішньополітичних партнерів і продовжувати балансування між всіма своїми стратегічними партнерами. (Наразі статус стратегічного партнера ТР мають Україна, Грузія, США і Росія).

Так, разом з небажанням Анкари допускати розширення присутності НАТО на Чорному морі на постійній основі, ВМС ТР беруть активну участь в інформаційному обміні, спільних операціях та морських навчаннях, таких як PASSEX або Sea Breeze, розроблених з метою підвищення оперативної сумісності країн-учасниць на морі, на суходолі та в повітрі.

Туреччина також приділяє увагу розвитку тісного співробітництва 3 Україною та Грузією, як в рамках НАТО, так і на двосторонній основі. Протягом останніх років Анкара значно активізувала співпрацю з Києвом у військово-технічній сфері та ОПК, включаючи постачання професійних систем зв'язку та БПЛА для потреб збройних сил України. У 2019 році сторони заявили про створення спільного українсько-ту- 
рецького підприємства «Чорноморський щит», покликаного об’єднати технологічний та промисловий потенціал двох країн у галузі авіації, безпеки та оборони (Ukraine and Turkey, 2019).

Оскільки протиріччя з Росією щодо Криму, Лівії та Сирії залишають все менше місця для спільних інтересів, а відносини з західними партнерами переживають чергову кризу, для ТР розвиток співпраці 3 Україною є хорошою альтернативою, що дозволить полегшити залежність від військово-оборонного співробітництва з Росією та сприятиме реалізації одвічної мрії турецького керівництва - створенню автономного національного ОПК з власним виробництвом повного циклу.

Одним з важливих питань, які ще доведеться вирішувати турецькому керівництву, залишається питання Проток і статус нового штучного Каналу Стамбул - як з точки зору міжнародного права, так і балансу сил у регіоні. Досі не зрозуміло, чи поширюватимуться на нього положення конвенції Монтре, яка регулює режим проходження через протоки та накладає обмеження на тоннажність і термін перебування військових кораблів нечорноморських країн у басейні Чорного моря.

У преамбулі документа загальний термін «протоки» трактується як «протоки Босфор, Дарданелли і Мармурове море», при цьому статус будь-яких інших водних артерій залишається невизначеним (Convention Regarding, 1936, с. 225-227). Експерти одностайні в тому, що, коли йдеться про торгове судноплавство, Анкара має повне право не тільки стягувати плату за прохід через штучний канал, який перебуває в межах суверенної території Туреччини, а й регулювати судноплавний трафік згідно з положеннями національного законодавства. Набагато складніше розібратися з застосуванням обмежень Монтре на клас і термін перебування в Чорному морі військових кораблів нечорноморських країн, які потраплять у нього через нову «точку входу», оминувши Босфор.

Дискусії спалахнули з новою силою після заяв Ердогана, що Конвенція «обов'язкова» тільки для проток Босфор і Дарданелли, а Канал Стамбул «буде повністю виведено зі сфери ії дії». За його словами, «Канал працюватиме як водна артерія Туреччини», а тому він «не має жодного зв'язку з режимом Монтре» (Hincks, 2020). Це може сигналізувати про кардинальні зміни в майже столітній практиці ТР розглядати Конвенцію Монтре як непорушний принцип регіональної політики, що дозволяв обмежувати присутність натівських кораблів у басейні Чорного моря. Якщо ж відтепер її положення не будуть поширюватися на новий Канал Стамбул, це може істотно змінити баланс сил у регіоні.

Досі всі спроби внести будь-які зміни до Конвенції Монтре наражалися на категоричну відмову Анкари. Очевидно, що й «Росія прагну- 
ла б продовження дії режиму Монтре задля уникнення нових невизначеностей та викликів, особливо після анексії Криму з Севастополем, де базується її Чорноморський флот» (Tuygan, 2020).

Водночас нарощування військової сили РФ у Східному Середземномор'ї так само не відповідає інтересам Анкари, як і постійна присутність НАТО в басейні Чорного моря. В турецьких ЗМІ вже декілька разів з'являлися заяви вищого керівництва держави про можливість перекриття Босфору для російських кораблів, що прямують до Сирії, у випадку подальшого загострення ситуації в Ідлібі (Turkey May Close, 2020).

Зважаючи на нинішній рівень відносин з Заходом, Анкара навряд чи захоче провокувати серйозну кризу у відносинах з Росією чи відкривати регіон для натівських військових кораблів. Втім, можливість вільного трактування положень Конвенції Монтре у зв'язку з запуском каналу Стамбул може дати турецькому керівництву більшу гнучкість у прийнятті зовнішньополітичних рішень і значно зміцнити переговірні позиції ТР у діалозі як з Москвою, так і з Вашингтоном - внаслідок встановлення хиткого балансу сил та загроз між обома стратегічними партнерами з супротивними інтересами.

\section{Висновки}

Важливою особливістю сучасних міжнародних відносин $є$ виникнення нових потужних регіональних лідерів у різних частинах світу й тенденція до регіоналізації світової системи безпеки. Хоч на глобальному рівні переважаюча міць США все ще зберігається, регіональні держави відіграють дедалі активнішу роль в межах окремих регіонів.

В умовах поступового переходу до багатополярної структури світової системи з частковим перерозподілом влади між її центрами, своє значення, як і раніше, зберігають механізми балансу сил, загроз та інтересів. Тому для дослідження політики Туреччини в Чорноморському регіоні доцільним $є$ застосування концепції неореалізму, яка забезпечує для цього достатню теоретично-методологічну базу. Водночас застосування доробку конструктивізму дозволило також врахувати в аналізі фактори культурного, ідеологічного порядку, вплив історичної спадщини та соціальної взаємодії.

Дослідивши сучасний стан відносин Туреччини 3 ключовими гравцями в регіоні, а також особливості турецької стратегічної культури, можна з великою долею вірогідності говорити про майбутні сценарії розвитку.

Сценарій виходу ТР із НАТО на користь створення союзу з Росі$\underline{\epsilon}$ задля посилення власних позицій в регіоні наразі є мало реальним. Спільне бажання обмежити вплив США і НАТО в Чорному морі робить 3 Анкари та Москви тактичних союзників, але не допомагає зміцненню 
взаємної довіри й стратегічного партнерства в довгостроковій перспективі. Якою б успішною не була співпраця двох регіональних лідерів, історично, стратегічно й навіть психологічно турецько-російські відносини приречені залишатися в парадигмі суперництва та боротьби за контроль над протоками.

Відмова від співпраці з Росією на тлі загострення протиріч навколо Лівії, Сирії або Криму також є маловірогідною, враховуючи спільні інтереси Туреччини та РФ з інших стратегічно важливих напрямів та глибоку кризу в трансатлантичному партнерстві. У період загострення протиріч з Росією Анкара може виявляти більшу готовність до розвитку військово-морського співробітництва з союзниками по НАТО. Але турецьке керівництво використовуватиме ці тимчасові послаблення в традиційній політиці недопущення в регіон зовнішніх гравців як додатковий елемент торгу в діалозі з партнерами як на сході, так і на заході, аніж як можливість посилення присутності Альянсу в Чорному морі.

Найбільш вірогідним наразі є сценарій, за яким Анкара продовжуватиме прагматичну політику балансування між всіма ключовими гравцями в регіоні, керуючись власними національними інтересами та прагненням зберегти вигідний для себе статус-кво. Це означає, що поглиблюючи співпрацю та вступаючи до ситуативної коаліції з Росією, Анкара все ж зберігатиме довгострокові стратегічні відносини 3 Вашингтоном.

Разом 3 тим варто очікувати, що Туреччина дедалі частіше виступатиме з власними регіональними ініціативами, навіть якщо вони суперечитимуть блоковим зобов'язанням по НАТО, але того вимагатиме розвиток ситуації в Чорноморському регіоні, Східному Середземномор'ї чи Близькому Сході. Прагматичне балансування Туреччини між Росією та США залишається наріжним каменем зовнішньої політики Анкари, i немає жодних причин вважати, що це може змінитися в найближчому майбутньому.

\section{Список посилань}

1. Babacan, A. (2008, 23 September). Calming the Caucasus. The New York Times. Retrieved from http://www.nytimes.com/2008/09/23/opinion/23iht-edbabacan.1.164 07371.html

2. Becker, D. (2014). Memory and Trauma as Elements of Identity in Foreign Policy Making. In E. Resende, D. Budryte (Eds.) Memory and Trauma in International Relations: Theories, Cases and Debates, 57-74. Routledge.

3. Blank, S. (2016). Putin's Dream of the Black Sea as a Russian Lake. Newsweek. Retrieved from http://www.newsweek.com/putin-dream-black-sea-russian-lake-476321 
4. Brooks, S. \& Wohlforth, W. (2002). American Primacy in Perspective. Foreign Affairs, 81 (4), 20-33.

5. Celikpala, M. (2010). Escalating Rivalries and Diverging Interests: Prospects for Stability and Security in the Black Sea Region. Southeast European and Black Sea Studies, 10 (3), 287-302.

6. Cohen, A. \& Conway, I. (2006). U.S. Strategy in the Black Sea Region. Backgrounder, 1990. The Heritage Foundation.

7. Convention Regarding the Regime of the Straits, Montreux (1936). United Nations Treaty Series, 173 (4015). Retrieved from https://treaties.un.org/doc/ Publication/UNTS/LON/Volume\%20173/v173.pdf

8. Devlen, B. (2014). Don't Poke the Russian Bear: Turkish Policy in the Ukrainian Crisis. Policy Brief of the Norwegian Peace-Building Resource Center.

9. Flanagan, S. \& Larrabee, S. (2020). Turkey's Nationalist Course: Implications for the U.S.-Turkish Strategic Partnership and the U.S. Army. RAND Corporation Research Report. Retrieved from https://www.rand.org/pubs/research_ reports/RR2589.html

10. Hincks, J. (2020). How the Kanal Istanbul Is Dividing Erdogan's Turkey. Time. Retrieved from: https://time.com/5783560/canal-istanbul-erdogan-imamoglu-infrastructure/

11. Hopf, T. (1998). The Promise of Constructivism in International Relations Theory. International Security, 23 (1), 171-200.

12. Huntington, S. (1999) The Lonely Superpower. Foreign Affairs, 78 (2), 35-49.

13. Koru, S. (2017). Turkey's Black Sea Policy: Navigating Between Russia and the West. Black Sea Strategy Papers. Retrieved from https://www.fpri.org/ article/2017/07/turkeys-black-sea-policy-navigating-russia-west/

14. Kurtdarcan, B. \& Kayaoglu, B. (2017). Russia, Turkey and the Black Sea A2/ AD Arms Race. National Interest. Retrieved from http://nationalinterest.org/ feature/russia-turkey-the-black-sea-a2-ad-arms-race-19673

15. Layne, C. (2006). The Peace of Illusions: American Grand Strategy from 1940 to the Present. Ithaca: Cornell University Press.

16. Lynch, D. (2003). A Regional Insecurity Dynamic. In D. Lynch (Ed). The South Caucasus: A Challenge for the EU, 10-22, Paris: EUISS.

17. Mearsheimer, J. (2001). The Tragedy of Great Power Politics. N.Y.: Norton \& Co.

18. Mikhelidze, N. (2017). Turkey's Policy in the Black Sea Region: Oscillating Between Pragmatism and Opportunism. In S. Toperich \& A. Ünver Noi (Ed.) Turkey and Transatlantic Relations, 133-149, Washington D.C.: Center for Transatlantic Relations.

19. Petriashvili, S. (2015). Where is the Black Sea Region in Turkey's Foreign Policy? Turkish Policy Quarterly, 14 (3), 105-112. Retrieved from http://turkishpolicy.com/article/777/where-is-the-black-sea-region-in-turkeys-foreignpolicy\#_ftn16

20. Press Release Regarding the Tension in the Azov Sea and Kerch Strait №321 (2018). Official web-site of the Ministry of Foreign Affairs of the Republic of Turkey. Retrieved from http://www.mfa.gov.tr/no-321-azak-denizi-ve-kercbogazindaki-gerginlik-hken.en.mfa 
21. Schweller, R. (1994). Bandwagoning for Profit: Bringing the Revisionist State Back. International Security, 1, 72-107.

22. Snyder, G. (1997). Alliance Politics. Ithaca: Cornell University Press.

23. Snyder, J. \& Christensen, T. (1990). Chained Gangs and Passed Bucks: Predicting Alliance Patterns in Multipolarity. International Organization, 44 (2), $137-168$.

24. Socor, V. (2005). Black Sea Watch. Eurasia Daily Monitor, 2 (34). Retrieved from https://jamestown.org/program/black-sea-watch/

25. Socor, V. (2018). Turkey Stalls NATO, Clings to Defunct Status Quo in the Black Sea. Eurasia Daily Monitor, 15 (116). Retrieved from https://jamestown. $\quad$ org/program/turkey-stalls-nato-clings-to-defunct-status-quo-in-theblack-sea/

26. Tol, G. (2019). Balance in the Black Sea: Complex Dynamic between Turkey, Russia and NATO. Middle East Institute Policy Analysis. Retrieved from https://www.mei.edu/publications/balance-black-sea-complex-dynamic-between-turkey-russia-and-nato

27. Toucas, B. (2018). Turkey Has No Allies in the Black Sea, Only Interests. CSIS Commentary. Retrieved from https://www.csis.org/analysis/turkey-hasno-allies-black-sea-only-interests

28. Turkey May Close the Bosphorus to Russia Warships. (2020). Middle East Monitor. Retrieved from https://www.middleeastmonitor.com/20200224-turkey-may-close-the-bosphorus-to-russia-warships/

29. Turkey Threatens to Block NATO's Baltic Defence Plan Over YPG. (2019). Aljazeera. Retrieved from https:/www.aljazeera.com/news/2019/12/turkey-threate ns-block-nato-baltic-defence-plan-ypg-191203083651527.html

30. Turkish Foreign Policy (2019). Research on Public Perceptions by Kadir Has University. Retrieved from https://www.khas.edu.tr/en/haberler/research-public-perce ptions-turkish-foreign-policy-2019

31. Türkiye Eğilimleri - 2019 (Тенденції Туреччини - 2019). (2020). Public Opinion Survey by Kadir Has University. Retrieved from https://www.khas. edu.tr/sites/khas.edu.tr/files/inlinefiles/TE2019_TUR_BASIN_15.01.20\%20 WEB\%20versiyon\%20power point_0.pdf.

32. Tuygan, A. (2020). The Montreux Convention: Russia's Perspective. EDAM. Retrieved from https://edam.org.tr/en/the-montreux-convention-russias-perspective/

33. Ukraine and Turkey Set Up a Joint Venture in Precision Weapons and Aerospace Technologies. (2019). Official web-site of the National Security and Defence Council of Ukraine. Retrieved from https://www.rnbo.gov.ua/en/Diialnist $/ 3345 . h$ tml

34. Walker, J. (2008) Reexamining the U.S.-Turkish Alliance. The Washington Quarterly, 31 (1), 93-109.

35. Walt, S. (1987). Alliance Formation and the Balance of World Power. International Security, 9 (4), 3-43.

36. Waltz, K. (1979). Theory of International Politics. N.Y.: Random House.

37. Whiteneck, D. (2001). Long-Term Bandwagoning and Short-Term Balancing: The Lessons of the Coalition Behaviour from 1792 to 1815. Review of International Studies, 27, 151-168. 
38. Winrow, G. (2007). Turkey and the Greater Black Sea Region. In N. A. Guney (Ed). Contentious Issues of Security and the Future of Turkey, 121-134. Ashgate Publishing.

39. Wohlforth, W. (1999). The Stability of a Unipolar World. International Security, 24 (1), 5-41.

40. Yalınkılıçlı, E. (2017, October 16). Turkey's "Near Abroad" in the Black Sea: Ankara's Predicament Between Kiev and Moscow. Daily Sabah. Retrieved from https:/www.dailysabah.com/op-ed/2017/10/16/turkeys-near-abroad-inthe-black-sea-ankaras-predicament-between-kiev-and-moscow. 


\section{РОЗДІЛ 3 \\ АНЕКСІЯ КРИМУ: \\ ПРАВОВІ ТА БЕЗПЕКОВІ ПЕРТУРБАЦЇ̈}

(Глебов С. В.)

\section{Bcmyn}

Якщо ми погоджуємось 3 тим, що історія людства - це історія воєн, то ми також повинні погодитися й з тим, що Російська Федерація доклала максимум зусиль щоб підтвердити релевантність такого стародавнього драматичного підходу до ланцюга історичних подій XXI ст. Разом 3 тим, починаючи з Першої світової війни, і з часів Другої світової війни, і особливо після закінчення Холодної війни, певна частина людства намагалася уникнути такої войовничої фатальності, принаймні в межах розширеного кола демократичних держав. Певна порція надії, особливо в Європі, покінчити з такою історією (якщо не з наступним етапом конфлікту цивілізацій) шляхом залучення до нього Нових незалежних держав (ННД), включаючи пострадянську Росію, з'явилася після офіційного зникнення СРСР, тоді як процес створення нового світового порядку постбіполярного зразка почав давати збій вже наприкінці століття. Отже, постбіполярне глобальне переупорядкування значно ускладнилося 3 використанням Росією гібридних механізмів ведення проксі-війн проти колишніх радянських республік та решти демократичного світу для виправдання власного бачення майбутнього світового порядку. Війна, нав'язана Україні, та російська військова агресія повернули нас до часів «холодної війни» і відродили дні тріумфу неореалістів. Як зізнається Стівен Роузфілд з Університету Північної Кароліни в Чапел-Хілл, «анексія Криму Росією 18 березня 2014 р. сповістила про кінець пострадянського світового порядку, заснованого на партнерстві та західних вільсоніанських ідеалістичних концепціях права, демократії та святості національної незалежності» (Rosefielde, 2017, с. 45). Західний трикутник США-НАТО-СС виявився не лише ворогом, але й головним конкурентом Кремля у відновленні розділових ліній під час становлення «старомодних» сфер впливу в епоху після Холодної війни. Росія сприйняла намір цієї трійки поділитися гарантіями безпеки та демократичними цінностями в процесі розширення НАТО та СС на Схід як загрози для себе.

Отже, цілком ідеалістична, але з деякими об'єктивними підставами, надія замінити постбіполярну європейську історію воєн історією миру остаточно зазнала невдачі в 2014 р. внаслідок анексії Криму. «Укра- 
їнська криза, швидше за все, не просто регіональна проблема», - сказала Ангела Меркель, канцлер Німеччини, у виступі в Інституті міжнародної політики Лойві в Сіднеї (Австралія) в листопаді 2014 р. «В цьому випадку ми бачимо, що вона (анексія) впливає на нас усіх». «Хто б міг подумати, - продовжила канцлерка, - що через 25 років після падіння Стіни, після закінчення Холодної війни, після закінчення поділу Європи та зникненням світу, розділеного навпіл, щось таке може статися безпосередньо в центрі Свропи?» (Smale, 2014). Питання канцлерки сьогодні звучить досить риторично, оскільки «захоплення Путіним Криму було настільки вражаючим, настільки руйнуючим очікування Заходу, що багато лідерів, здавалося, забули, що він був лідером Росії протягом останніх півтора десятиліть», і безумовно, «не новий хлопчик у дворі» (Kalb, 2015 , с. 2). Сьогодні важливим $є$ те, що Захід мало що може нав'язати путінській Росії у майбутньому у зв'язку з трагічними подіями в Україні, хоча кейс $з$ анексією Криму в 2014 р. є досить повчальним.

\section{Крим як об'єкт зіткнення: ретроспектива}

Історичність стратегічної фрази героя Кримської війни адмірала Нахімова «кому належить Крим, тому належить і Чорне море» окреслила важливість бази Чорноморського флоту в Севастополі для російської імперської державності, а також значення всього Чорноморського регіону для Російської Федерації. Як сакралізував Володимир Путін, це регіон «за который столько косточек русских положено в течение всех предыдущих веков» («Прямая линия», 2014). «Історична рана» імперії, завдана Микитою Хрущовим, який у 1954 р. прийняв рішення передати Крим Україні, «сочилася» до лютого 2014 р. Хтось може стверджувати, що процес передачі в 1954 р. міг бути більш підготовленим і краще спланованим, «але неважливо хто і як оцінює оперативність територіальної реконфігурації; головний момент, на якому слід наголосити, полягає в тому, що неправильно говорити (як нещодавно говорили деякі російські коментатори та урядовці) про те, що Крим було передано неконституційно або незаконно» (Kramer, 2014). Як підсумовує Марк Крамер, директор Програми досліджень Холодної війни в Гарвардському університеті, «правова система в Радянському Союзі була здебільшого вигадкою, але передача відбулася відповідно до діючих на той час правил» (Kramer, 2014). Справді, складно не погодитися з таким висновком, коли йдеться про внутрішні територіальні зміни в тоталітарній країні, де офіційний статус Радянського Союзу як федерації був фіктивним, враховуючи авторитарне правління Комуністичної партії СРСР Радянським Союзом. Незалежно від того, як було здійснено передачу, міждержавний адміністративний кордон між УРСР та РРФСР, а також територіальна 
цілісність кожної зі сторін, була підтверджена двостороннім договором від 19 листопада 1990 р., підписаним Борисом Сльциним та Леонідом Кравчуком в Києві ще за часів СРСР («Договор между РСФСР», 1990). Пізніше цю угоду було підтверджено Новими незалежними державами Україною та Російською Федерацією, які визнали правонаступництво УРСР і РРФСР відповідно.

Після розпаду СРСР непорушність кордонів новоутворених держав було підтверджено так званою «Біловерзькою угодою» 8 грудня 1991 р., яка декларувала, що Радянський Союз припинив своє існування, й проголосила створення Співдружності Незалежних Держав (СНД) («Соглашение о создании», 1991). Цей документ було підписано та схвалено українською й російською сторонами без будь-яких застережень щодо територіальної цілісності держав, що мали б бути у складі СНД. Крім того, 15 квітня 1994 р. в Москві було прийнято Декларацію про дотримання суверенітету, територіальної цілісності та недоторканності кордонів держав-членів Співдружності Незалежних Держав («Декларация о соблюдении», 1994). У цьому документі всі сторони, включаючи Російську Федерацію, висловили намір взаємно поважати суверенітет та підтвердили територіальну цілісність і недоторканість кордонів один одного («Декларация о соблюдении», 1994). Росія, серед інших ядерних держав, у Будапештському меморандумі про гарантії безпеки для України 1994 р. засвідчила, що буде «поважати незалежність і суверенітет та існуючі кордони України» й «утримуватися від загрози силою чи іï використання проти територіальної цілісності чи політичної незалежності України», i що «ніяка їхня зброя ніколи не буде використовуватися проти України» («Memorandum on Security», 1994). У більш широкому, «нормативному», значенні Будапештський меморандум 1994 р. виявився «чи не найвідомішим прикладом угоди, укладеної Україною з іншими державами щодо jus contra bellum» (Daulenov, 2018, с. 10). Як наполягає директор Академії правових та економічних досліджень Університету КАЗГЮУ в Астані Мірас Дауленов, «незважаючи на думку деяких авторів щодо необов'язкового характеру Будапештського меморандуму, він може розглядатися як договір, що надає матеріальні права та нав'язує юридичні зобов'язання, що регулюються міжнародним правом» (Daulenov, 2018, с. 11). Той факт, що ні права, ні обов'язки не набули чинності, $є$ окремим питанням, пов'язаним $з$ недостатньою ефективністю двосторонніх та багатосторонніх договорів та угод у сучасній міжнародній системі.

Непорушність кордонів та територіальна цілісність європейських держав підтверджується Заключним актом Конференції з питань безпе- 
ки та співробітництва в Свропі від 1 серпня 1975 р. I Україна, і Росія приєдналися до Гельсінкського Заключного акту, який зобов'язував держави-учасники «утримуватися... від застосування сили або загрози силою проти територіальної цілісності або політичної незалежності будьякої держави» та розглядати як непорушні «всі кордони один одного, як і кордони всіх держав в Свропі, i тому вони будуть утримуватися зараз і в майбутньому від будь-яких зазіхань на ці межі» (“Conference on Security”, 1975). В кінцевому рахунку, обидві сторони підписали Угоду про російсько-український державний кордон в січні 2003 р. («Договор между Российской Федерацией», 2003), яка підтвердила існуючі кордони між двома країнами відповідно до Статуту ООН та Гельсінського Заключного акту.

Тим не менше, анексія не була несподіваною: питання Криму та пов'язане з ним питання Чорноморського флоту та статусу Севастополя завжди були точками розбрату в російсько-українських відносинах. Спроба проголосити російський статус міста Севастополя (місто, яке було українським і де-факто, і де-юре) з боку російського парламенту мала місце 9 липня 1993 р., коли Верховна Рада РФ прийняла Постанову «О статусе города Севастополя» («Постановление ВС РФ», 1993). У документі зазначалося «підтвердити російський федеральний статус міста Севастополя в адміністративно-територіальних межах міського округу станом на грудень 1991 р.» (параграф 1) і було доручено відповідному парламентському комітету підготувати проект закону Російської Федерації про закріплення в Конституції Російської Федерації федерального статусу міста Севастополя (параграф 4) («Постановление ВС РФ», 1993). Цей провокаційний намір з боку вищого законодавчого органу Росії засудила Рада Безпеки ООН під головуванням сера Девіда Хеннея. Відзначаючи безпідставність російських вимог, Рада Безпеки ООН підтвердила територіальну цілісність України та недоторканність іiї кордонів («Complaint by Ukraine», 1993). У своєму відповіді на лист Міністерства закордонних справ України з проханням надати кваліфіковану оцінку Постанові Верховної Ради Російської Федерації «О статусе города Севастополя» від 9 липня 1993 р. сер Девід Хенней зазначав, що це рішення не мало юридичної сили («Complaint by Ukraine», 1993). У будь-якому випадку, Постанова порушувала пункт 4 статті 2 Статуту $\mathrm{OOH}$, який забороняє будь-яку загрозу чи застосування сили проти територіальної цілісності або політичної незалежності будь-якої держави (Charter of the United, 1945).

Примітно, що у виступі з цього питання в Раді Безпеки ООН влітку 1993 р. російський представник наголосив, що постанова, прийнята 
9 липня 1993 р. Верховною Радою РФ щодо статусу Севастополя, йде в розріз з політикою президента та уряду Російської Федерації. Російський представник стверджував, що його країна «залишається відданою принципу недоторканності кордонів у межах Співдружності Незалежних Держав і буде суворо дотримуватися своїх зобов'язань, передбачених міжнародним правом, Хартією та принципами НБСЄ» («Complaint by Ukraine», 1993). Він також запевнив Раду Безпеки ООН, що «щодо своїх відносин з Україною Російська Федерація й надалі керуватиметься двосторонніми договорами та угодами, зокрема тими, що стосуються поваги суверенітету та територіальної цілісності один одного» («Complaint by Ukraine», 1993). Ця, здавалося б, парадоксальна поліфонія в зовнішній політиці Росії щодо питання статусу Севастополя в 1993 р. може бути пояснена різкими внутрішньополітичним розбіжностями між адміністрацією президента Б. Єльцина та парламентом, які призвели до обстрілу будівлі російського парламенту в жовтні 1993 р. Ця двозначність у позиції Росії щодо статусу Севастополя в 1993 р. суттєво контрастує 3 політичною ясністю та рішучістю, проявленою в епоху президента Путіна всіма гілками влади. Кампанія анексії Криму в лютому-березні 2014 р. була підтримана як двома палатами російського парламенту, так і політичним апаратом країни.

Ризик військового зіткнення між Росією та Україною в Керченській протоці також був на порядку денному двосторонніх проблем ще за часів кризи 2003 р. навколо острова Тузла. Інцидент біля Тузли ще раз засвідчив намір російської влади підпорядкувати Керченську протоку під повний суверенітет РФ. Втім, анексія Криму Росією в 2014 р. стосувалася не лише території як такої. Це був не просто символічний акт відновлення статусу Криму як «російського» півострова. Мотивація була більш прагматичною й глибоко пов'язаною з історією відносин не лише між Україною та Росією, але й між Росією та Заходом як до 1991 р., так і після. Можна стверджувати, що однією з основних причин того, що Росія хотіла повернути суверенітет над Кримом, було ії усвідомлення стратегічного значення півострова під час відновлення геополітичного контролю над усім Чорноморським регіоном, яке стало головним пріоритетом на тлі загострень між Росією та НАТО з початку століття. Таке усвідомлення добре вкладалось в логіку «володіння Кримом» 3 метою «володіння Чорним морем».

Проблеми Чорноморського флоту та «перед-анексійні» виклики

Не буде перебільшенням стверджувати, що значний інтерес Росії до Криму завжди був пов'язаний з військово-морською базою радянського Чорноморського флоту в Севастополі. Чорноморський флот ко- 
лишнього СРСР був предметом переговорів між Росією та Україною 3 1995 р. щодо розподілу військових кораблів та матеріальної інфраструктури. Росія, за умовами Угоди про Чорноморський флот з Україною від 9 червня 1995 р., забезпечила собі 81,7 \% радянського Чорноморського флоту проти 18,3 \% для України («Угода між Україною та Російською», 1995). Водночас питання російської військово-морської бази в Україні завжди виходило далеко за межі військово-морського дискурсу та прийнятих угод. Претензії Росії після 1991 р. щодо колишнього радянського Чорноморського флоту та колишньої радянської Чорноморської військово-морської бази в Севастополі могли бути зрозумілими, але вони в жодному випадку не мали переходити до площини територіальних претензій. Тарас Кузьо (автор монографій «Росія-Крим-Україна. Трикутник конфлікту», 2007, та «Крим: наступний спалах Європи?», 2010) ще в 1995 р. зазначав, що провал спроб вирішити проблему Чорноморського флоту полягав саме в нездатності Росії визнати суверенітет України над Кримом та Севастополем (Кузьо, 1995, с. 45).

Російська Федерація виявилася фактично останньою країною Чорноморського регіону, яка визнала територіальну цілісність України та iii суверенітет над Севастополем і Кримом у двосторонньому «Великому» політичному Договорі про дружбу, співробітництво та партнерство між Україною та Російською Федерацією. Цей документ було підписано 31 травня 1997 р. («Договор о дружбе», 1997). Важливо зазначити, що цей Договір було підписано саме після того, як Україна погодилася утримувати Чорноморський флот Росії в Севастополі принаймні до 2017 р. Пакет угод про Чорноморський флот колишнього СРСР було підписано лише за кілька днів до цього, 28 травня 1997 р. («Соглашение между Российской Федерацией и Украиной о параметрах», 1997; «Соглашение между Российской Федерацией и Украиной о статусе», 1997; «Соглашение между правительством Российской Федерации», 1997). Незважаючи на сприятливі умови для Росії, «Великий» політичний договір тривалий час залишався нератифікованим Федеральними Зборами Росії й був остаточно затверджений лише 17 лютого 1999 р. (Україна ратифікувала Договір роком раніше, 14 січня 1998 р.). Варто зазначити, що в контексті триваючої війни Росії проти України остання, як очікувалося, заявила про свій намір не продовжувати дію Договору у вересні 2018 р., а отже, термін його дії закінчився 1 квітня 2019 р.

3 обранням Віктора Януковича президентом України в 2010 р. матеріалізувалася впевнена заява Росії про те, що «Чорноморський флот залишатиметься в Севастополі доти, поки це буде потрібно Росії» («Российский адмирал», 2007). Ратифікація так званого «Харківського пакту» 
в українському парламенті 27 квітня 2010 р., який подовжив термін перебування російського Чорноморського флоту в Криму до 2042 р., також довела, що Україна не пройшла тест на здатність й надалі йти шляхом євроатлантичної інтеграції. До того ж, за часів В. Януковича, позаблокову орієнтацію було проголошено Законом України «Про засади внутрішньої та зовнішньої політики» («Закон України Про засади», 2010), який було прийнято парламентською коаліцією 1 липня 2010 р. Відмова України від курсу на вступ до НАТО означала, що Росія забезпечила свій статус як єдиного військового «захисника» України. Сприйняття НАТО як загрози відіграло одну з вирішальних ролей у питанні анексії Криму. Загальна ідея такого провокаційного меседжу полягала в тому, що президент Росії намагався переконати росіян та увесь світ, що саме НАТО змусило його діяти, представляючи ситуацію так, ніби то НАТО вже розмістило свої бази в Криму. Достатньо лише згадати хитке «анти-натівське» виправдання анексії, озвучене президентом Росії В. Путіним під час його звернення до депутатів Державної Думи, членів Ради Федерації, керівників регіонів Росії та представників громадянського суспільства в Кремлі 18 березня 2014 р. («Address by President», 2014) та під час «прямої лінії» з росіянами 17 квітня 2014 р. («Прямая линия», 2014).

\section{Російська "спробувана» анексія Криму}

27 лютого 2014 р. російські війська в масках без розпізнавальних знаків, які видавали себе за спонтанних місцевих «борців за свободу», захопили парламент Криму та стратегічні місця на всьому півострові. Проросійський уряд в Криму офіційно ініціював незаконний референдум щодо статусу півострова, внаслідок чого 16 березня 2014 р. відбулося проголошення незалежності Криму. Верховна Рада Криму та Севастопольська міська рада проголосили незалежність Республіки Крим від України й офіційно попросили приєднатися до Російської Федерації наступного дня, 17 березня. Того ж дня Росія визнала Республіку Крим суверенною державою. Договір про приєднання Республіки Крим до Росії було підписано представниками Республіки Крим (включаючи Севастополь, з яким решта Криму ненадовго об'єдналася) та Російською Федерацією 18 березня 2014 р. У договорі було визначено умови для негайного прийняття Республіки Крим та Севастополя як федеральних суб’єктів РФ. 19 березня 2014 р. президент В. Путін подав до Державної Думи «договір про приєднання» Криму Росією та ініціював конституційну поправку щодо створення двох нових федеральних суб'єктів Російської Федерації. Після того, як російський конституційний суд підтримав конституційність договору, 20 березня 2014 р. Державна Дума ратифікувала його. Дума також схвалила проект федерального конститу- 
ційного закону про визнання Криму та Севастополя та про закріплення їх як федеральних суб'єктів. За день сам договір і необхідна поправка до статті 65 російської Конституції (в якій зазначено всі федеральні суб'єкти Росії) було ратифіковано Радою Федерації й майже негайно підписано російським президентом В. Путіним як представником закону. 2 квітня 2014 р. Росія офіційно денонсувала «Харківський пакт» 2010 р., а також пакет угод про Чорноморський флот від 28 травня 1997 р.

У будь-якому випадку, позиція України була зрозумілою з самого початку: саме російське військове втручання в Україну в лютому 2014 р. призвело до анексії невід’ємної частини іiї території. Анексія - це «офіційний акт, за допомогою якого держава заявляє про свій суверенітет над територією, яка раніше була поза ії юрисдикцією», як визначає термін «анексія» електронна енциклопедія Колумбійського університету («Annexation», 2017). Анексія Криму, в принципі, не може бути класифікована ні як законна, ані як незаконна в тому сенсі, що сама «анексія» $\mathrm{E}$ «володінням, яке було відібране у вигляді земельної ділянки або частини країни, як правило, силою або без дозволу», як трактує поняття «анекciï» Кембриджський словник («Annexation», 2020). Саме Крим було вилучено з-під юрисдикції України силою та без дозволу. I це при тому, що, наприклад, Гельсинський Заключний Акт НБСЄ зобов'язує держави-учасниці «утримуватися також від будь-яких вимог або дій, спрямованих на захоплення й узурпацію частини або всієї території будь-якої держави-учасника» («Conference on Security», 1975).

Позиція ж Росії в контексті регіонального та глобального дискурсу щодо анексії Криму закріплює тезу про «мирне возз'єднання». Як заявив президент Росії Володимир Путін на саміті СНД у столиці Киргизстану 16 вересня 2016 р., Москва не анексувала український півострів Крим у 2014 р., а просто сприяла його возз’єднанню з Росією («Putin Says», 2016). Відразу після незаконного референдуму в Криму в березні 2014 р. міністр закордонних справ Росії Сергій Лавров застерігав проти того, щоб термін «анексія», «як його застосовують деякі західні політики, не застосовувався до процесу приєднання Криму до Росії» та стверджував, що його застосування «ображає півострів» («Лавров назвал», 2014).

Венеціанська комісія Ради Свропи оцінила так званий «референдум про статус Криму» як такий, який не відповідав ані Конституції України, ані загальним демократичним стандартам. Ця позиція була озвучена Комісією 21 березня 2014 р. 3 посиланням на те, що «Конституція України забороняє будь-який місцевий референдум, який міг би змінити територію України» («Opinion on», 2014). Комісія зазначила, що рішення про призначення місцевого референдуму в Криму не поширю- 
ється на повноваження, передані органам влади Автономної Республіки Крим на підставі статті 138 Конституції України. Така оцінка «референдуму» повторилася в Резолюції Генеральної Асамблеї ООН 68/262 про «Територіальну цілісність України» від 27 березня 2014 р., й зазначила, що «референдум, проведений в Автономній Республіці Крим та м. Севастополі 16 березня 2014 р., не має чинності, не може стати підставою для будь-якої зміни статусу Автономної Республіки Крим або м. Севастополя» («Territorial integrity», 2014).

У безуспішній спробі перетворити тлумачення міжнародного права на свою користь під час легітимізації «референдуму» Російська Федерація посилалася на право на самовизначення народів як основу для відокремлення Криму від України. Примітно, але Кремль стверджував, що жителі Криму саме реалізовували своє «волевиявлення» щодо права на самовизначення. Як заявив 20 березня 2014 р. міністр закордонних справ Росії Сергій Лавров, «рішення про прийняття Республіки Крим до складу Російської Федерації базується на волевиявленні багатонаціонального народу Криму під час березневого референдуму» («Speech by the Russian», 2014). За його оцінкою, «це рішення відповідає міжнародному праву, включаючи принцип суверенної рівності держави та права людей на самовизначення, як основної мети ООН, зазначеної в Статуті» («Speech by the Russian», 2014). Білл Боурінг з юридичної школи Лондонського університету Біркбек заперечує та наголошує, що «... Росія просто помилилася». На думку Боурінга, «право на самовизначення реалізовувалося «мешканцями Криму», «кримчанами», хоча єдиним «народом», що має право на самовизначення в Криму, є кримськотатарський народ, корінне населення Криму» (Bowring, 2018, с.35). Хоча й не існує повністю визнаного поняття «народу», але часто посилаються на визначення, запропоноване Спеціальним доповідачем ООН Мартінесом Кобо у дослідженні щодо дискримінації корінного населення, де «корінні громади, народи та нації - це ті, що мають історичну наступність 3 суспільством, що розвинулось на їх територіях до вторгнення та за часів доколоніального періоду, і вважають себе відмінними від інших секторів суспільства, що зараз переважає на цих територіях або їх частинах» («Martinez Cobo», 1986). Крім того можна стверджувати, що серед усіх етнічних груп Криму найбільше від вторгнення Росії постраждали саме коріннє населення - татари. Не дивно, що заступник голови Меджлісу кримськотатарського народу Ільмі Умеров публічно заявив, що 95 \% кримських татар не визнають юрисдикцію Російської Федерації в анексованому Криму, навіть якщо вони не проголошують це відкрито зі зрозумілих причин («95 \% of Crimean», 2019). 
Схоже, Сергій Лавров також «помилився», коли намагався пов'язати міжнародне право «народів на самовизначення» з волею Кремля надати право «багатонаціональному народові» Криму. Як зазначає директор Польського інституту міжнародних відносин (PISM) Славомір Дебскі, збройна агресія Росії проти України йшла паралельно з російською агресією проти міжнародного права, оскільки «діяльність російського уряду щодо Криму фактично виходить за межі ведення звичайної юридичної справи - і як така може розглядатися як форма «міжнародно-правового тролінгу», що прагне підірвати, релятивізувати й зруйнувати міжнародний правовий порядок» (Debski, 2017, с. 14). «3 цієї точки зору, - продовжує Дебскі, - найбільш руйнівним аргументом, на який посилається Росія для виправдання своїх дій проти України, було цитування попередніх прикладів міжнародно-правових порушень» (Debski, 2017, с. 14). Одним $з$ таких прикладів стало посилання російського президента на косовський прецедент («Address by President», 2014) - хоча й можна погодитись, що «в політичному плані анексія Криму була б складнішою, якби косовський прецедент не з'явився раніше» (Czaplinski, 2017, с. 35). Тим не менше, Патриця Гжебик з Інституту міжнародних відносин Варшавського університету стосовно подій у Криму зазначає, що «міжнародний суд ООН не санкціонував так званий прецедент Косово, тобто право на відокремлення, як про це стверджувалося, й не йшлося про те, що Косово має право на відокремлення, а йшлося лише про те, що факт проголошення декларації про незалежність не може розглядатися як порушення міжнародного права» (Grzebyk, 2017, c.145).

Разом 3 тим Крістіан Маркссен з Інституту порівняльного публічного права та міжнародного права імені Макса Планка в Гейдельберзі визнає, що, хоча «право на самовизначення є фундаментальним принципом міжнародного права й включене до статті 1 (2) Уставу ООН, ...прийнято розуміти, що концепція самовизначення не може використовуватися для дезагрегації території існуючих національних держав» (Marxsen, 2014, с. 385). Маркссен посилається на Декларацію про дружні відносини, в якій зазначено, що принцип самовизначення не можна «тлумачити як санкціонування або заохочення будь-яких дій, які повністю або частково розчленують чи погіршать територіальну цілісність або політичну єдність суверенних і незалежних держав - поки держави поважають принцип рівних прав та самовизначення щодо груп меншин» (Marxsen, 2014, с. 385). Розмірковуючи над різними науковими аргументами, викладеними з цього питання, Симон Ф. ван ден Дрієст, доцент Центру міжнародних правових досліджень Гроція Лейденського університету, робить такий висновок: «Загалом слід зробити висновок, 
що аргументи щодо передбачуваного права на самовизначення та (коректування) відокремлення, висунуті кримською та російською владою, якими вони намагаються виправдати події на Кримському півострові, не можуть бути підтримані. Навпаки, одностороннє відокремлення Криму від України було явно незаконним згідно з міжнародним правом» (van den Driest, 2015).

Повертаючись до невдоволення російським міністром зовнішніх справ вживанням терміна «анексія», слід зазначити, що це якимось іронічним чином відповідає офіційній позиції Києва щодо подій лютого-березня 2014 р. Пізніше прийнятий відповідний закон України не посилається на будь-яку «анексію» або «анексовану територію», але визначає сухопутну територію Автономної Республіки Крим та міста Севастополя разом з внутрішніми морськими водами й територіальним морем України навколо Кримського півострова, територію виключної (морської) економічної зони України вздовж узбережжя Кримського півострова та прилеглого до узбережжя континентального шельфу України, надра під зазначеними вище територіями, і повітряний простір над цими територіями як «тимчасово окуповані території» (стаття 3 Закону України 2014 року «Про забезпечення прав і свобод громадян та правовий режим на тимчасово окупованій території України») («Закон України Про забезпечення», 2014).

Зі стратегічної точки зору та для просування вимоги щодо відновлення суверенітету над Кримом у контексті міжнародного права для України було важливо зазначити умовність окупації де-юре, щоб зафіксувати фактичний статус-кво анексії, але не визнати ії. Валентина Азарова (Юридична школа Університету Коч та Центр глобального публічного права в Стамбулі) використовує термін «окупація» стосовно «ситуацій окупації, які підтримуються незаконною силою з метою захоплення території або з метою іiі відокремлення» (Azarova, 2018, с. 43). У коментарі 1958 р. до Конвенції (IV) щодо захисту цивільних осіб у воєнний час у посиланні на розділ про «Анексію» зазначено таке: «окупація території у воєнний час $\epsilon$, по суті, тимчасовою фактичною ситуацією, яка не позбавляє окуповану Державу ні іiі державності, ні суверенітету; вона просто втручається в його повноваження реалізовувати свої права. Це те, що відрізняє окупацію від анексії, коли окупаційна держава одержує всю або частину окупованої території та додає іiї до своєї території» («Convention (IV)», 1958).

Висновок авторів цього коментаря $є$ ще більш значущим в контексті того, що анексію не можна розглядати як таку, що передбачає визнання такої форми набуття суверенітету з боку окупаційної держави. 
Тривала робота над Конвенцією одразу після закінчення Другої світової війни тільки підсилює це твердження. Для більш чіткого визначення незаконного характеру анексії у воєнний час урядові експерти в 1947 р. запропонували додати сполучник «нібито» у значенні «уявна» перед словом «анексія» («Convention (IV)», 1958). Прикметник «спробувана», використаний державним секретарем США Рексом Тіллерсоном 7 грудня 2017 р. перед російським міністром закордонних справ на засіданні ОБСЄ у Відні, висвітлює ту ж логіку: «Ми ніколи не приймемо окупацію Росії та спробувану анексію Криму» («Remarks at OSCE», 2017). США та їхні західні союзники приділили особливу увагу концептуально-правовому оформленню російської окупації Криму саме як «спробуваної анексії», щоб засвідчити відсутність у них визнання будь-якого фактичного статус-кво, заподіяного Росією. Як заявив наступний держсекретар США Майкл Помпео в Кримській декларації від 25 липня 2018 року: «Росія внаслідок вторгнення до України в 2014 році та спробуваної анексії Криму намагалася підірвати міжнародний принцип, який підтримують демократичні держави: жодна країна силою не може змінити кордони іншої» («Crimea Declaration», 2018).

Висловлюючи думку про те, що «діяльність Росії в Криму викликає нагальні питання щодо... доцільності використання правової категорії «войовнича окупація» в сучасних ситуаціях іноземного контролю над територією» (Azarova, 2018, с. 42), Азарова визначає сучасний статус Криму «як незаконного територіального режиму, заснованого на об'єктивній незаконності, яка є наслідком порушення імперативних норм міжнародного права (jus cogens), що має на меті зміну міжнародного статусу території, а також її державної системи та демографічних характеристик» (Azarova, 2018, с. 43). В ситуації, коли Крим одночасно $\epsilon$ «нібито» й «уявно анексованим» У де-юре розумінні та «войовниче окупованим» у фактичному сенсі, очевидним є те, що саме Росія вторглася на українську територію, захопила Крим, а пізніше й деякі частини Донбасу та Луганської області на заході України. У вторгненні були задіяні ударні сили російських військових, які не мали розпізнавальних знаків, і спроба Росії заперечити будь-яку безпосередню участь у воєнній агресії зазнала невдачі майже одразу після події. Спочатку, ще 4 березня 2014 р., президент Росії Володимир Путін відкрито заперечував будьяку участь збройних сил РФ в дні захоплення Криму, стверджуючи, що бойові групи були «місцевими підрозділами самооборони» («Vladimir Putin answered», 2014). Але менш ніж за два місяці під час сеансу запитань та відповідей з громадянами Росії 1 квітня 2014 р. Володимиру Путіну довелося принаймні двічі зізнатися, що військові у формі в ма- 
сках без розпізнавальних знаків, які захоплювали парламент Криму та інші стратегічні об'єкти, справді були російськими солдатами: «За спиной сил самообороны Крыма, конечно, встали наши военнослужащие. Они действовали очень корректно, но, как я уже сказал, решительно и профессионально» («Прямая линия», 2014). Трохи пізніше під час тієї ж розмови Путін заявив: «Россия не присоединяла Крым силой. Россия создала условия, с помощью, конечно, специальных формирований и Вооружённых Сил, я прямо скажу, но создала только условия для свободного волеизъявления людей, которые проживают в Крыму и Севастополе» («Прямая линия», 2014). Так, Гельсінський Заключний акт зазначає, що «всі народи завжди мають право... визначати... свій внутрішній і зовнішній політичний статус... та здійснювати на свій розсуд свій політичний, економічний, соціальний і культурний розвиток», але саме за умови «повної свободи» та «без втручання ззовні» («Conference on Security», 1975). Отже, така сповідь Путіна, серед іншого, свідчить про визнання факту порушення умов одного з головних джерел сучасного міжнародного права з боку російського президента, а також спростовує висловлювання Сергія Лаврова про «вільне волевиявлення», яке апріорі не може мати місце «під дулом пістолета».

Таке заперечення безпосередньої участі російських військових в захопленні Криму було зрозумілим з огляду на контекст міжнародного права. Визнаючи протилежне, дії Росії безпосередньо підпадали б під визначення «агресії» відповідно до Декларації ООН 3314 про визначення агресії. Стаття 3, пункт А Декларації не допускає двозначного тлумачення, стверджуючи, що незалежно від того, чи було оголошено війну, чи ні, «... вторгнення або напад збройних сил держави на територію іншої держави або будь-яка військова окупація, хоч б тимчасова, що виникла в результаті такого вторгнення або нападу, або будь-якої анексії з застосуванням сили щодо території іншої держави або ï частини має бути кваліфікована як акт агресії» («Definition of Aggression», 1974).

Як уже було зазначено, пункт 4, розділу 1, статті 2 Статуту Організації Об'єднаних Націй забороняє будь-яку загрозу чи застосування сили проти територіальної цілісності чи політичної незалежності будьякої держави або в будь-який іншій спосіб, що не відповідає цілям ООН (Charter of the United, 1945). Взагалі стаття 2 (4) Статуту ООН закріплює один 3 ключових принципів, на який посилаються при розгляді питань, що стосуються агресії на міжнародній арені. Здається, це квінтесенція jus ad bellum (закон про застосування сили) або jus contra bellum (закон про запобігання війни), який має на меті обмежити застосування сили між державами-членами ООН. Як стверджує Мірас Дауленов, «чи не 
найважливішим тлумаченням статті 2 (4) Статуту ООН, яка може бути застосована до ситуації в Україні, є визнання того, що територія держави не повинна бути об'єктом військової окупації внаслідок застосування сили. 3 цієї причини жодне територіальне надбання, спричинене загрозою чи застосуванням сили, не може визнаватися законним» (Daulenov, 2018, с. 10). Звичайно ж, винятки з цього принципу передбачаються у випадках самозахисту або в діях, що грунтуються на рішеннях, прийнятих Радою Безпеки ООН відповідно до розділу VII Статуту ООН. Саме в статті 51 Статуту зазначено про винятки зі заборони застосування сили, передбачені в статті 2 (4). Згідно з цим документом право індивідуальної або колективної самооборони може бути реалізоване в разі «збройного нападу» на члена ООН і може застосовуватися доти, поки Рада Безпеки не почне вживати заходи, необхідні для підтримки міжнародного миру й безпеки (Charter of the United, 1945).

Зрозуміло, що Росія не мала міжнародно-затвердженого права діяти відповідно до положень статті 51 під час застосування сили проти України. Саме суверенна держава Україна була об'єктом «збройного нападу» з боку Російської Федерації в Криму; а російські військовослужбовці в масках, які носили камуфляжну військову форму без розпізнавальних знаків, не були «місцевими підрозділами самооборони», що представляли «багатонаціональний народ Криму», або «жителів Криму» відповідно до першої інформації з Росії, яку російський президент згодом спростував. Таким чином, робить висновок Дауленов, «формування Росією нерегулярних сил та збройних груп з метою військової окупації (частини) території України слід розглядати як порушення іiї міжнародних зобов'язань» (Daulenov, 2018, с. 10). І в цьому контексті Росія вкотре порушила свої зобов'язання, зокрема, в рамках Гельсінського Заключного акту НБСЄ, який передбачає, що «держави-учасники будуть утримуватися від надання безпосередньої чи опосередкованої допомоги терористичній діяльності, підривної чи іншої діяльності, спрямованої на насильницьке повалення режиму другої держави-учасниці» («Conference on Security», 1975).

Не випадково анексія Криму Росією та продовження гібридної російської агресії на сході України стали частинами глобального порядку денного міжнародних відносин та міжнародного права. Оскільки понад 100 країн відкрито засудили збройну агресію РФ проти України, Росія опинилася в ізоляції на міжнародному рівні. Чисельність країн, які під час 80-го пленарного засідання 27 березня 2014 р. підтримали резолюцію 68/262 Генеральної Асамблеї про «Територіальну цілісність України» («Territorial integrity», 2014), яскраво контрастує з тією оди- 
надцяткою, яка проголосувала проти резолюції. 19 грудня 2016 р. Генеральна Асамблея Організації Об'єднаних Націй прийняла резолюцію про права людини в Криму, яка стала першим міжнародним документом, що визначив Російську Федерацію як окупаційну державу, а Автономну Республіку Крим та місто Севастополь тимчасово окупованими територіями. Резолюція підтвердила територіальну цілісність України й невизнання анексії українського півострова («Situation of human», 2016). Такий висновок логічно підсилює один з основоположних принципів міжнародних відносин, який передбачає, що держави мають «утримуватися від того, щоб перетворювати територію одна одної на об'єкт військової окупації, інших безпосередніх чи опосередкованих заходів застосування сили на порушення міжнародного права або на об'єкт придбання за допомогою таких заходів чи загрози їх здійснення» («Conference on Security», 1975); що «ніяка окупація не буде визнаватися законною» («Conference on Security», 1975). Саме це чітко продемонструвало цивілізоване міжнародне співтовариство.

Західні держави послідовно підтримують Україну. Позиція ЄС не залишала місця для двозначного тлумачення його підтримки. 13 березня 2014 р. Свропарламент у Резолюції про вторгнення Росії до України рішуче засудив «акт агресії Росії при вторгненні до Криму, який є невіддільною частиною України і визнаний таким як Російською Федерацією, так і міжнародним співтовариством...», закликав «до негайної деескалації кризи з виведенням усіх збройних сил, які незаконно перебувають на території України» та «до повної поваги міжнародного права та існуючих традиційних зобов’язань» («Invasion of Ukraine», 2014). Всього через кілька днів, 20-21 березня 2014 р., у документі з висновками засідання Європейської Ради, в параграфі 29 зазначено, що Європейський Союз продовжує «підтримувати суверенітет і територіальну цілісність України», а також не визнає і не визнає «незаконний референдум у Криму», або «незаконне приєднання Криму та Севастополя до Російської Федерації» («European Council Conclusions», 2014). Однак слід наголосити, що ЄС утримався від використання таких характеристик «анексії» як «уявна» чи «спробувана», критичних з політичної та правової точок зору. Хоча $\mathrm{CC}$ не пропонував Україні безпосередньої практичної допомоги для захисту від Росії, він запровадив галузеві санкції проти Росії разом із США.

Минуло 6 років з того часу, як Росія «тимчасово» окупувала Крим i деякі частини Донецької та Луганської областей на сході України. Так званий Мінський процес та «Нормандська четвірка» досягли незначного прогресу в тому, щоб переконати Росію деокупувати українські терито- 
piї на Сході, тоді як справа Криму (який тепер має зв’язок з Росією завдяки збудованому «керченському мосту») практично відійшла на задній план як в Україні, так і в міжнародній спільноті. Питання повернення Криму Україні залишається відкритим на порядку денному двосторонніх відносин між Україною та Росією. Обидві сторони, перш за все Україна, визнають, що військового рішення не існує, і для будь-якої спроби вирішення цього питання залишаються лише політичні та дипломатичні інструменти. Водночас, як і в 2014 р., Захід єдиний у своїй позиції щодо поточного та майбутнього статусу півострова, в рамках якого вони готові сприймати Крим. «НАТО підтримує суверенітет та територіальну цілісність України. НАТО не визнає і не буде визнавати незаконну та нелегітимну анексію Криму Росією. Всі союзники по НАТО єдині в засудженні агресивних дій Росії», - заявив Генеральний секретар НАТО Йєнс Столтенберг на спільній прес-конференції з президентом України Володимиром Зеленським у Києві 31 жовтня 2019 року («Stoltenberg: NATO», 2019). Практично ідентичну позицію висловив держсекретар США Майкл Помпео на спільній прес-конференції з президентом В. Зеленським також у Києві 31 січня 2020 р. («The United States will», 2020). М. Помпео заявив, що він детально обговорив відносини між Україною та Росією з президентом В. Зеленським, і США: «Сполучені Штати прагнуть захистити суверенітет і територіальну цілісність України й продовжують підтримувати Україну в питанні приєднання до НАТО та наближення до Свропейського Союзу» («The United States will», 2020). У цьому ж контексті М. Помпео нагадав, що в листопаді 2018 року було відновлено роботу Комісії стратегічного партнерства США та України, і що США схвалили Кримську декларацію, яка в липні 2019 року чітко підтвердила, що Крим є частиною України («The United States will», 2020). Більше того, М. Помпео зазначав, що в березні попереднього року США координували введення додаткових санкцій проти Росії з Канадою та європейськими союзниками у відповідь на російський напад на українські судна в Керченській протоці, а також продовжили санкції проти «Північного потоку-2» у грудні 2019 р. («The United States will», 2020). Зі свого боку, в заяві, озвученій під час засідання Постійної ради ОБСЄ у Відні 27 лютого 2020 р., делегація Європейського Союзу в ОБСЄ запевнила Україну, що СС залишається повністю відданим невизнанню незаконної анексії Криму Росією («European Union Delegation», 2020). Позиція США, СС та інших західних держав щодо кримського питання фактично перекликається з теоретизуванням Белен Джуппоні зі Школи права, соціальних та поведінкових наук Кінгстонського університету про те, що залучення іноземної території шляхом анексії є незаконним 
міжнародним актом, який зобов’язує як держави, так і міжнародні організації не визнавати його, оскільки це є результатом порушення імперативних норм (Giupponi, 2019, с. 154).

\section{Висновки та прогнози}

Завдяки агресії проти України та «спробуваної» анексії Криму в лютому-березні 2014 р. Росія стала першою та єдиною колишньою наддержавою, ядерною державою й постійним членом Ради Безпеки ООН, яка незаконно захопила, тимчасово окупувала та фактично інтегрувала територію сусідньої країни. Москва відкрито виявила свою волю й рішучість не поважати міжнародне право та використовувати військову силу для досягнення своїх геополітичних інтересів та амбіцій. Російська військова агресія та гібридна війна проти України повернули іiі відносини з Заходом до умов «холодної війни» та ознаменували тріумф неореалістської школи міжнародних відносин. Активне використання військової сили Росією у 2014 р. можна розглядати як підтвердження свого небажання сприймати дію певного набору правил, які не влаштовують (D’Anieri, 2017, с. 277). Через агресію проти України Росія підірвала глобальну довіру та здатність до співпраці в процесі формування багатополярного світового порядку. Отже, «анексію Криму не потрібно розглядати як кінцеву гру В. Путіна. Він сприймає це як вихідну точку для політично стійкої довготривалої боротьби за внутрішній та зовнішній контроль не лише всередині Росії а й по їі периметру» (Rosefielde, 2017, с. 27). Дійсно, «завершення конфлікту вимагатиме, i, ймовірно, допоможе сформувати новий механізм безпеки в Європі», але цілком ймовірно, що конфлікт буде тривати «доти, поки Росія не прийме бачення Заходу Свропи або Захід не прийме Росію... з Україною посередині» (D’Anieri, 2017, с. 277). Виникають сумніви щодо готовності Росії йти назустріч закликам Заходу щодо деескалації ситуації на сході України. Про потенційне повернення Криму до України, здається, зовсім не йдеться, тому, що будь-які поступки Заходу розглядатимуться Кремлем як висловлення слабкості. Російські владні інституції здебільшого не довіряють Заходу й не будуть «зачаровані вмовляннями США та СС щодо здорового глузду та доброї волі» (Rosefielde, 2017, с. 27). Росія Путіна чітко відокремилася від Заходу й відмовилася від будь-якого подальшого дискурсу щодо створення спільної європейської та євроатлантичної системи безпеки й співробітництва $з$ довгостроковою перспективою. Навіть якщо Захід мовчки прийме анексію Криму, «Путін, ймовірно, продовжуватиме проектувати могутність Росії як ревізіоністську й підривну владу, доки Захід не поступиться йому прийнятним рівнем влади в рамках нового світового порядку» (Rosefielde, 2017, с. 27). 
Україна перебуває в дуже незручному становищі, оскільки їй потрібно забезпечити національні інтереси таким чином, щоб вони в кінцевому результаті не стали розмінною монетою задля якогось оманливого зближення Росії та Заходу. Якщо припинення бойових дій на Донбасі $\epsilon$ практично можливим за умови, якщо Захід й надалі буде тиснути на Росію, то повернення Криму до України є маловірогідним. На тлі дедалі голосніших тверджень 3 боку Росії про те, що «Росія може розмістити ядерну зброю в Криму, оскільки вона є частиною іiі території» («Deployment of Russian», 2015), та постійно триваючих масштабних військових навчань на півострові, виявляється, що Росія налаштована рішуче перетворити Крим на неприступну фортецю проти НАТО. Крім того, увесь цей Кримський кейс зараз вже $є$ не просто питанням міжнародних відносин, він безпосередньо стосується територіальної цілісності Росії. «Республіка Крим» вважається конституційним суб'єктом Російської Федерації, тоді як Севастополь визначається як місто федерального значення - так як Москва та Санкт-Петербург - згідно зі статтею 65 Конституції Росії. Отже, цілком логічно говорити про те, що скасування так званої анексії Криму не є основою прогнозованого мейнстримовського сценарію розвитку подій в майбутньому.

\section{Список посилань}

1. Декларация о соблюдении суверенитета, территориальной целостности и неприкосновенности границ государств-участников Содружества Независимых Государств. (1994, 15 апреля). Політика і час, 1994, 6, 87-88.

2. Договор между Российской Федерацией и Украиной о российско-украинской государственной границе. (2003, 28 января). Президент России. Взято $3 \mathrm{http}: / / \mathrm{kremlin} . r u /$ supplement $/ 1653$

3. Договор между РСФСР и УССР. (1990, 19 ноября). Ведомости Съезда народных депутатов РСФСР и Верховного Совета РСФСР, 1990, 27, Ст. 353.

4. Договор о дружбе, сотрудничестве и партнерстве между Российской Федерацией и Украиной. (1997, 31 мая). Бюллетень международных договоров, 1999, 7, 50-58.

5. Закон України «Про засади внутрішньої і зовнішньої політики». (2010, 1 липня). Відомості Верховної Ради України (ВВР), 40, ст. 527.

6. Закон України «Про забезпечення прав і свобод громадян та правовий режим на тимчасово окупованій території України». (2014). Відомості Верховної Ради (ВВР), 26, ст.892.

7. Кузьо, Т. (1995). Чеченська криза і «ближнє зарубіжжя», Політика $i$ час, $8,42-52$.

8. Лавров назвал оскорбительными заявления Запада об аннексии Крыма. (2014, 21 марта). Взгляд. Взято 3 https://vz.ru/news/2014/3/21/678310.html 
9. Постановление ВС РФ от 09.07.1993 n 5359-1 «О статусе города Севастополя〉 (1993, 9 июля). Викитека. Взято 3 https://ru.wikisource.org/

10. Российский адмирал: Севастополь еще долго будет базой ЧФ. (2007, 23 июля 2007). Корреспондент. Взято $3 \mathrm{https}$ ://korrespondent.net/ukraine/ politics/199880-rossijskij-admiral-sevastopol-eshche-dolgo-budet-bazoj-chf

11. Соглашение между правительством Российской Федерации и правительством Украины о взаиморасчетах, связанных с разделом Черноморского флота и пребыванием Черноморского флота Российской Федерации на территории Украины. (1997, 28 мая 1997). Бюллетень международныхх договоров, 1999, 10, 80-83.

12. Соглашение между Российской Федерацией и Украиной о параметрах раздела Черноморского флота. (1997, 28 мая 1997). Бюллетень международных договоров, 1999, 10, 34-37.

13. Соглашение между Российской Федерацией и Украиной о статусе и условиях пребывания Черноморского флота Российской Федерации на территории Украины. (1997, 28 мая 1997). Бюллетень международных договоров, 1999, 10, 74-80.

14. Соглашение о создании Содружества Независимых Государств. (1991, 8 декабря). Дипломатический вестник, 1992, 1, 3-6.

15. Угода між Україною та Російською Федерацією щодо Чорноморського флоту (укр/рос), 643_082. (1995, 9 июня). Верховна Рада України. Взято 3 https://zakon.rada.gov.ua/laws/show/643 082

16. $95 \%$ of Crimean Tatars do not recognize Russian jurisdiction in Crimea. (2019, August 14). ATR.ua. Retrieved from https://atr.ua/news/189783-95-ofcrimean-tatars-do-not-recognize-russian-jurisdiction-in-crimea

17. Address by President of the Russian Federation. Vladimir Putin addressed State Duma deputies, Federation Council members, heads of Russian regions and civil society representatives in the Kremlin. (2014, March 18). President of Russia. Retrieved from http://en.kremlin.ru/events/president/news/20603

18. Annexation. (2017). The Columbia Electronic Encyclopaedia, 6th ed. Retrieved from https://www.infoplease.com/encyclopedia/social-science/government/concepts/annexation

19. Annexation. (2020). The Cambridge Dictionary. Cambridge University Press. Retrieved from https://dictionary.cambridge.org/us/dictionary/english/annexation

20. Azarova, V. (2018). An illegal territorial regime? On the occupation and annexation of Crimea as a matter of international law. In Sayapin, S. \& Tsybulenko, E. (Eds.). The use of force against Ukraine and international law: jus ad bellum, jus in bello, jus post bellum, 41-72. Berlin Heidelberg: Asser Press by Springer-Verlag.

21. Bodner, M. (2014, January 22). Russia's 8 Most Memorable Davos Moments. The Moscow Times. Retrieved from https://www.themoscowtimes. com/2014/01/22/russias-8-most-memorable-davos-moments-a31309

22. Bowring, B. (2018). Who are the "Crimean People" or "People of Crimea"? The fate of the Crimean Tatars, Russia's legal justification for annexation, and Pandora's box. In Sayapin, S. \& Tsybulenko, E. (Eds.). The use of force 
against Ukraine and international law: jus ad bellum, jus in bello, jus post bellum, 20-40. Berlin Heidelberg: Asser Press by Springer-Verlag.

23. Charter of the United Nations. (1945, June 26). United Nations. Retrieved from http://www.un.org/en/sections/un-charter/chapter-i/index.html

24. Complaint by Ukraine regarding the Decree of the Supreme Soviet of the Russian Federation concerning Sevastopol. (1993, 20 July). United Nations. Retrieved from http://www.un.org/ar/sc/repertoire/93-95/Chapter\%208/EUROPE/96-95_8-22-UKRAINE.pdf

25. Conference on Security and Co-operation in Europe Final act. (1975, August 1). OSCE. Retrieved from https://www.osce.org/helsinki-final-act?download $=$ true

26. Convention (IV) relative to the Protection of Civilian Persons in Time of War. Geneva, 12 August 1949. Commentary of 1958. Treaties, States Parties and Commentaries. (1958). International Committee of the Red Cross. Retrieved from https://ihl-databases.icrc.org/applic/ihl/ihl.nsf/Comment. xsp?action $=$ openDocument\&documentId $=$ C4712FE71392AFE1C12563CD$0042 \mathrm{C} 34 \mathrm{~A}$

27. Crimea Declaration. Press Statement. Michael R. Pompeo, Secretary of State, Washington D.C. (2018, July 25). The U.S. Department of State. Retrieved from https://www.state.gov/crimea-declaration/

28. Czaplinski, W. (2017). Self-determination - secession - recognition (remarks on the international legal background to the incorporation of Crimea into the Russian Federation). In Wierczynska, K., W. Czaplinski, W., Debski, S., \& Tarnogorski, R. (Eds.). The Case of Crimea's Annexation under International Law, 23-42. Warsaw: Wydawnictwo Naukowe Scolar.

29. D'Anieri, P. (2017). Ukraine and Russia: From civilized divorce to uncivil war. Cambridge: Cambridge University Press.

30. Daulenov, M. (2018). The legal nature of states' obligations towards Ukraine in the context of jus contra bellum. In Sayapin S. \& Tsybulenko E. (Eds.). The use of force against Ukraine and international law: jus ad bellum, jus in bello, jus post bellum, 4-19. Berlin Heidelberg: Asser Press by Springer-Verlag.

31. Debski, S. (2017). Law, politics and the Future of Crimea. In Wierczynska, K., W. Czaplinski, W., Debski, S., \& Tarnogorski, R. (Eds.). The Case of Crimea's Annexation under International Law, 13-19. Warsaw: Wydawnictwo Naukowe Scolar.

32. Definition of Aggression - UN Documents: Gathering a body of global agreements. (1974, December 14). United Nations. Retrieved from http://www. un-documents.net/a29r3314.htm

33. Deployment of Russian nuclear weapons in Crimea possible - Foreign Ministry. (2015, March 11). TASS. Retrieved from http://tass.ru/en/russia/782071

34. European Council Conclusions. (2014, March 20-21). European Council. Retrieved from http://www.consilium.europa.eu/uedocs/cms_data/docs/pressdata/en/ec/141749.pdf

35. European Union Delegation to the OSCE has assured that the EU remains fully committed to non-recognition of the illegal annexation of Crimea by Russia. (2020, February 28). Ukrinform. Retrieved from https://www.ukrinform. 
net/rubric-polytics/2886028-eu-annexation-of-crimea-is-an-act-we-will-never-recognize.html

36. Giupponi, B. O. (2019). Exploring the links between nationality changes and investment claims arising out of armed conflicts: the case of Russian passportization in Crimea. In Gómez K., Gourgourinis A., \& Cham C. (Eds.). International Investment Law and the Law of Armed Conflict, 153-172. Switzerland: Springer Nature Switzerland.

37. Grzebyk, P. (2017). The annexation of Crimea in the light of the definition of Aggression. Does prohibition of aggression apply to Russia? In Wierczynska, K., W. Czaplinski, W., Debski, S., \& Tarnogorski, R. (Eds.). The Case of Crimea's Annexation under International Law, 137-154. Warsaw: Wydawnictwo Naukowe Scolar.

38. Invasion of Ukraine by Russia, 2014/2627(RSP). (2014, March 13). European Parliament. Retrieved from http://www.europarl.europa.eu/sides/getDoc.do?type $=$ TA\&reference $=$ P7-TA-2014-0248\&language $=\mathrm{EN}$

39. Kalb, M. L. (2015). Imperial Gamble: Putin, Ukraine, and the new cold war, Washington, D.C.: Brookings Institution Press.

40. Kramer, M. (2014). Why Did Russia Give Away Crimea Sixty Years Ago? Wilsoncenter.org, CWIHP e-Dossier No. 47. Retrieved from https://www.wilsoncenter.org/publication/why-did-russia-give-away-crimea-sixty-years-ago

41. Martinez Cobo Study of the Problem of Discrimination Against Indigenous Populations, Sub-Commission on the Prevention of Discrimination and the Protection of Minorities, UN Doc. E/CN.4/Sub.2/1986/7/Add.4. (1981, July 30). United Nations. Retrieved from https://www.un.org/development/desa/ indigenouspeoples/about-us.html

42. Marxsen, Ch. (2014). The Crimea Crisis - An International Law Perspective. Zeitschrift für ausländisches öffentliches Recht und Völkerrecht (Heidelberg Journal of International Law), 74/2, 367-391.

43. Memorandum on Security Assurances in connection with Ukraine's accession to the Treaty on the Non-Proliferation of Nuclear Weapons. (1994, December 5). PIR Center. Retrieved from http://www.pircenter.org/media/content/ files/12/13943175580.pdf

44. Opinion on "whether the decision taken by the Supreme Council of the Autonomous Republic of Crimea in Ukraine to organise a referendum on becoming a constituent territory of the Russian Federation or restoring Crimea's 1992 Constitution is compatible with constitutional principles" adopted by the Venice Commission at its 98th Plenary Session, CDL-AD(2014)002. (2014, March 21-22). Venice Commission. Retrieved from https://www.venice.coe. int/webforms/documents/?pdf=CDL-AD(2014)002-e

45. Putin Says Crimea Not Annexed By Russia, It Was 'Reunified'. (2016, September 17). Radio Free Europe/Radio Liberty. Retrieved from https://www.rferl. org/a/putin-says-crimea-not-annexed-was-reunified-with-russia/27996702. html

46. Remarks at OSCE Plenary Meeting. Rex W. Tillerson, Secretary of State. Hofburg Palace, Vienna, Austria. (2017). The U.S. Department of State. Retrieved from https://www.state.gov/secretary/remarks/2017/12/276319.htm 
47. Rosefielde, S. (2017). The Kremlin strikes back: Russia and the West after Crimea's annexation. New York: Cambridge University Press.

48. Situation of human rights in the Autonomous Republic of Crimea and the city of Sevastopol (Ukraine): resolution A/RES/71/205/ adopted by the General Assembly. (2016, December 19). United Nations. Retrieved https://digitallibrary.un.org/record/855181? $\ln =\mathrm{ru}$

49. Smale, A. (2014, November 17). Merkel Issues Rebuke to Russia, Setting Caution Aside. The New York Times. Retrieved from https://www.nytimes. com/2014/11/18/world/europe/russia-deports-german-polish-diplomats-retaliation.html

50. Speech by the Russian Foreign Minister, Sergey Lavrov, and his answers to questions from deputies during the plenary session of the State Duma of the Russian Federation, Moscow. (2014, March 20). The Ministry of Foreign Affairs of the Russian Federation. Retrieved from https://www.mid.ru/en/ web/guest/foreign_policy/news/-/asset_publisher/cKNonkJE02Bw/content/ $\mathrm{id} / 69626$ 609-20-03-2014

51. Stoltenberg: NATO will never recognize Russia's annexation of Crimea. (2019, October 31). Kyiv Post. Retrieved from https://www.kyivpost.com/ ukraine-politics/stoltenberg-nato-will-never-recognize-russias-annexation-of-crimea.html

52. Territorial integrity of Ukraine, UN GA Resolution 68/262. (2014, March 27). GUAM. Retrieved from https://guam-organization.org/en/un-ga-resolution-68-262-territorial-integrity-of-ukraine/

53. The Constitution of the Russian Federation. (1993, December 12). The Ministry of Foreign Affairs of the Russian Federation. Retrieved from https://www. mid.ru/en/foreign_policy/official_documents/

54. The United States will never recognize Russia's annexation of Crimea and supports Ukraine's efforts to join NATO, U.S. Secretary of State Mike Pompeo has said. (2020, January 31). Ukrinform. Retrieved from https://www.ukrinform.net/rubric-polytics/2866950-us-will-never-recognize-russias-annexation-of-crimea-pompeo.html

55. Transcript: Vladimir Putin's April 17 Q\&A. (2014, April 17). The Washington Post. Retrieved from https://www.washingtonpost.com/world/transcript-vladimir-putins-april-17-qanda/2014/04/17/ff77b4a2-c635-11e3-8b9a8e0977a24aeb_story.html

56. van den Driest, S. (2015). Crimea's Separation from Ukraine: An Analysis of the Right to Self-Determination and (Remedial) Secession in International Law. Netherlands International Law Review, 62, 329-363.

57. Vladimir Putin answered journalists' questions on the situation in Ukraine. (2014, March 4). President of Russia. Retrieved from http://en.kremlin.ru/ events/president/news/20366 


\section{РОЗДІЛ 4 \\ РОСІЙСЬКИЙ ЧОРНОМОРСЬКИЙ ФЛОТ: ЧИ Є МІСЦЕ ДЛЯ СТРАТЕГІЧНОГО ВИМІРУ?}

(Сіновець П. А.)

\section{Bcmyn}

Початок 2020 року ознаменувався новиною: з борту керованого ракетного крейсера «Маршал Устинов» Верховний головнокомандувач Збройних сил Росії Володимир Путін спостерігав за спільними навчаннями із залученням Північного та Чорноморського флотів у Чорному морі. Під час навчань було випущено різні ракети, в тому числі крилаті ракети «Калібр» і гіперзвукова балістична ракета «Кинджал». (Joint exercises of Northern and Black Sea fleets, 2020).

Чи вирізняється якось ця військова активність серед широкого кола російських військових тренувань, які регулярно організовує Москва після анексії Криму? Відповідь - «так і ні». 3 одного боку, росіяни не відступали від своєї військової поведінки примусу, демонструючи власну військову силу знову і знову. Але з іншого - суть їхніх військових тренувань дає деякі підстави для роздумів.

У жовтні минулого року військові навчання «Грім-2019» імітували участь Росії у світовій ядерній війні та відродили «ядерну карту» в російській військовій риториці (Гольц, 2019). Підготовка Російських військово-морських сил на Чорному морі 2020 р. певним чином є доказом цього.

Можна стверджувати, що Росія є найбільшою ядерною державою, тому не слід дивуватися ії ядерним навчанням. Найнеприємнішим фактом $€$ те, що цього разу навчання з можливим ядерним компонентом проходили у Чорному морі, майже в самому центрі Європи. Окрім того, їх проводили в Криму, який більшість світових гравців вважає територією України. І це повертає нас до принципу «ескалації для деескалації», який, зазвичай, заперечується Росією й частково розмивається суттєвим акцентом на традиційному стримуванні, який останнім часом робить Москва.

Метою цього розділу є визначення рівня ядерної складової у Чорноморській стратегії Росії в межах загальних цілей, які Росія намітила в регіоні.

По-перше, ми пропонуємо розглянути загальні принципи російської стратегії стримування, зокрема, суперечливу «ескалацію для деескалації», або ж використання ядерної зброї на певному етапі конфлікту для його деескалації. 
Цілком впевнено можна стверджувати, що оскільки «ескалація для деескалації» існує, то іiї докази слід шукати не на військових навчаннях «Захід». Вони є традиційним маркером аналізу ставлення Росії до війни iз Заходом, і останнім часом були в основному орієнтовані на імітацію патової ситуації в контексті звичайних озброєнь. Треба звертати увагу на розвиток Російського військово-морського флоту, його доктринальний контекст та контекст матеріального забезпечення. Військово-морський флот є частиною Російських збройних сил, що найактивніше розвивається (оскільки він був найменш розвиненим протягом багатьох років), тому його доктринальний контекст і цикл матеріального забезпечення дещо відстають від сухопутних військ та відображають найновіші тренди російської військової стратегії.

У зв'язку з цим проаналізуємо такі питання :

1. «Ескалація для деескалації» як принцип у російському воєнному мисленні та його сприйняття на Заході;

2. Основні тенденції розвитку російського флоту та його зв'язок зі славнозвісною російською «зброєю першого березня»;

3. Роль Криму та російського Чорноморського флоту в стратегічному плануванні Москви.

xодi

Стратегія «ескалація для деескалації» та ії сприйняття на За-

Згідно з оглядом американської ядерної доктрини (АЯД), російська ядерна стратегія закликає до попереджувального застосування ядерної зброї в разі конфлікту з НАТО з метою змусити основного противника відступитися від втручання до регіонального конфлікту Росії з сусідами. Зокрема АЯД коментує: «Вона [Москва] помилково розцінює, що загроза ядерної ескалації або фактичного першого використання ядерної зброї забезпечить «деескалацію» конфлікту на вигідних для Росії умовах» (Nuclear Posture Review Final Report, 2018).

3 іншого боку, у своєму валдайському виступі у 2018 р. президент В. Путін однозначно заявив: «Тільки тоді, коли ми точно знатимемо - а треба всього кілька секунд, щоб зрозуміти - що на Росію нападають, ми нанесемо контрудар... Звичайно, це буде глобальна катастрофа, але я хотів би повторити, що ми не можемо стати ініціаторами такої катастрофи, оскільки у нас немає положень щодо нанесення превентивного удару» (Заседания дискуссионного клуба Валдай,2018).

Ці майже протилежні твердження стали предметом обговорення експертів щодо значення «ескалації для деескалації». Зокрема, Метью Кронінг з Атлантичної Ради попередив, що Росія готова до попереджувального використання ядерної зброї лише для того, щоб змусити НАТО 
«закликати до миру або ризикувати через подальшу потенційно катастрофічну ескалацію з використанням ядерної зброї» (Kroening, 2018). Тому основне обговорення було зосереджено навколо ідеї запобігання попереджувального застосування ядерної зброї Росією.

Значна кількість експертів заперечує існування принципу «ескалації для деескалації» в російській стратегії. Зокрема, Крістен Вен Бруусгаард зазначала, що конвенційний російський арсенал, який швидко розвивається, разом із доктринальними заявами свідчить про збільшення ядерного порога. Вона також вказала на раціональність російської влади, яка, ймовірно, ніколи б не почала ядерного конфлікту з такою потужною організацією як НАTO (Ven Buusgaard, 2017). Водночас Ольга Олікер та Андрій Баклицький говорять про в основному конвенційний характер військових навчань «Захід-2017», які, зазвичай, симулюють російський конфлікт із Заходом (Oliker \& Baklitskiy, 2018).

Здебільшого, жоден з експертів не заперечує манеру примусу російської ядерної поведінки, а також той факт, що в певний момент під час великого конфлікту росіяни, ймовірно, застосують ядерну зброю. Основна відмінність між висловлюваннями експертів, швидше за все, полягає у часі/етапі, на якому російська сторона забажає застосувати ядерну зброю. Чи станеться це на ранній стадії конфлікту, розпочатого Москвою, з метою розколоти НАТО шляхом атаки на деякі з колишніх російських сфер впливу, такі як Балтика, чи ядерну зброю до сьогодні вважають останнім засобом, який може бути застосований на етапі, коли росіяни вже не зможуть стримувати спроби НАТО втручатися у сфери впливу Москви й щоб виштовхнути альянс з Криму?

Такі експертні обговорення завжди супроводжувались російськими військовими навчаннями, що підтверджували справедливість аргументів кожної сторони. Зокрема, навчання «Схід-2018» виявилися найбільшими у військовій історії РФ після конвенційних навчань «Захід-2017» 1982 р. А в 2019 р. Росія провела навчання «Грім-2019», і деякі з коментаторів називають їх «репетицією глобальної ядерної війни» (Гольц, 2019).

3 огляду на це, ми хотіли б дослідити справжню суть явища, яке Захід називає «ескалацією для деескалації» в російській стратегії. Для того, щоб зробити це дослідження успішним, слід посилатися на факти з історії цього поняття та його походження.

Ідея «ескалації для деескалації» була сформульована на початку минулого десятиліття, коли, з одного боку, Росія істотно поступалася Заходу в контексті звичайних озброєнь, а з іншого, насправді була стурбована тим, щоб не повторити долю Сербії в 1999 р. 
Тут слід згадати три важливі речі. По-перше, російську військову доктрину 2000 р., коли Москва заявила про можливість використання ядерної зброї в регіональній війні «через критичні обставини, коли звичайні засоби довели свою неефективність» (Военная доктрина Российской Федерации, 2000). Стримування традиційних конфліктів (особливо регіональних воєн) ядерною зброєю означає, що ядерну зброю розглядають як можливий засіб реагування на цей тип конфлікту. Вона служить головною гарантією того, що Росія не буде переможена й навіть втягнута до регіональної війни.

По-друге, цю ідею доповнила концепція наперед визначеної шкоди, що з'явилася в документі замість поняття «неприйнятна шкода». Наперед визначена шкода визначається як «шкода, суб' єктивно неприйнятна для противника, що є більшою за переваги, на які агресор очікує від застосування військової сили» (Военная доктрина Российской Федерации, 2000). Це поняття, ймовірно, не прийнятне, коли йдеться про виживання держави або ії̈ найближчих союзників (наприклад, країн НАТО для США), але добре поєднується з ідеєю регіональної війни, яка ведеться поза сферою життєво важливих інтересів США. За словами авторів, «проаналізувавши співвідношення втрат і вигід, агресор, отримавши певний збиток від ядерної зброї, відступить». По-третє, не варто забувати й про концепцію обмежених стратегічних ядерних ударів, розроблену Російським міністерством оборони в 2003 p. i, попри її відсутність в текстах офіційних російських доктрин в 2010 та 2014 рр., ніколи офіційно не скасовувалася (Актуальные задачи, 2003).

32010 р. російська військова доктрина намагається поєднати використання ядерної зброї з існуванням держави. «У випадку, якщо новий конвенційний конфлікт поставить під загрозу існування держави, володіння ядерною зброєю може призвести до трансформації звичайного конфлікту в ядерний» (Военная доктрина Российской Федерации, 2010). Тут значення поняття «існування» має вигляд досить розмитого: для Росії воно може суттєво відрізнятися від західного. Очевидно, що це не лише територіальна цілісність, а й виживання політичного режиму. Менш зрозуміло, чи містить воно життєво важливу сферу впливу. У будь-якому випадку поняття «існування» передбачає й поразку в масштабній (але меншій за глобальну) звичайній війні: поразка Сербії в 1999 p., очевидно, залишається референтним сценарієм.

Питання полягає в тому, чи має ця загроза реальне підгрунтя, чи це просто інструмент примусу? Росія завжди передбачала сценарії конфронтації з НАТО як агресію Альянсу через цілий ряд непередбачених обставин (включаючи, зокрема, Грузію чи Україну). НАТО, навпаки, од- 
нозначно розглядало російську погрозу використання ядерної зброї не як стримуючий фактор, а як інструмент, що дозволяє запобігти втручанню Заходу до розширення російського впливу (Sinovets, 2019).

Великий перехідний момент настав у 2014 р. До того часу Росія точно передбачала обмежене використання ядерної зброї в менш глобальних (регіональних) конфліктах з метою їх припинення за сприятливих умов, що, ймовірно, означало повернення до статус-кво, який був перед початком конфлікту. Але надалі це було тільки з метою стримати НАТО від участі в будь-яких конфліктах, які можуть призвести до великої поразки Росії.

У 2014 р. у новій Військовій доктрині було введено поняття звичайного стримування, яке, як мінімум, підвищило ядерний поріг і створило можливість ведення та припинення тих самих категорій конфліктів без застосування ядерної зброї. Однак опора на звичайну зброю при збільшенні порогу навряд чи змінить більш фундаментальний вибір: у будь-якому випадку звичайні удари повинні сигналізувати НАТО про серйозність намірів Москви та повідомляти про ризик того, що за умови продовження конфлікту, наступним кроком може стати використання ядерної зброї.

Водночас конвенційна зброя не має такого ж стримувального ефекту, як ядерна. Наскільки і за яких умов все ще вірогідне застосування ядерної зброї в регіональних конфліктах - невідомо. Така нечіткість, швидше за все, навмисна й закликає НАТО до надзвичайної обережності.

У військовій доктрині 2014 р. пункт про використання ядерної зброї було скорочено до «коли існування держави поставлено під загрозу» та все ще не уточнено характер загрози (Военная доктрина Российской Федерации, 2014). Вона була опублікована того ж року, коли Москва окупувала Крим, почала свою гібридну війну на Донбасі й активізувала військові маневри на кордоні з країнами Балтії. Останнє разом 3 концентрацією російських військ і численних провокацій російських стратегічних бомбардувальників в повітряному просторі НАТО викликало сильне занепокоєння на Заході. Постало питання: чи збираються росіяни провокувати регіональну війну в Свропі, де ядерний примус забезпечить Москві ескалаційне домінування.

Водночас, починаючи 32014 р., Москва не поспішала руйнувати сферу впливу НАТО, все ще демонструючи, що ії головний намір - утримати Захід подалі від колишніх радянських республік, що не належать до НАТО. Схоже, що Росія використовувала принцип «випадкової загрози», яскраво відображений у російській ядерній стратегії. Ніхто не знає 
напевно, коли і чи взагалі буде Росія готова застосувати ядерну зброю. До того ж більшість зброї, яка наразі виробляється в Росії, є зброєю подвійного призначення.

Документ «Основи державної політики Російської Федерації у сфері ядерного стримування», опублікований у червні 2020 р. підтверджує невизначеність російського стримування, а також запевняє Захід, що Москва:

1. буде використовувати ядерну зброю лише за екстремальних обставин;

2. якщо екстремальні обставини стосуються існування держави та іiі територіальної цілісності (чіткий натяк на Крим, який зазначено в оборонному периметрі Росії як fait accompli);

3. «ескалація для деескалації» все ще можлива, але лише в екстремальній ситуації, з якою Росія не зможе впоратися зі звичайною зброєю;

4. нечіткість масштабу, часу та місця використання ядерної зброї, що також опосередковано натякає на можливі сценарії деескалації (Basic Principles of State Policy of the Russian Federation on Nuclear, 2020).

Зважаючи на всі обставини, малоймовірно, що ядерне стримування усунуло обмежене застосування ядерної зброї в регіональних конфліктах із діапазону можливостей. Якщо Росія зіткнеться з серйозною поразкою у звичайному конфлікті, вона, однозначно, переступить ядерний поріг.

\section{Від розвитку російського флоту до «зброї периого березня»}

«Сьогодні ми повинні зважати на той факт, що розширення НАТО та розвиток його військової інфраструктури біля російських кордонів це одна із загроз для безпеки нашої держави. Саме тому ми приділяли та приділятимемо найважливішу увагу технічній ...модернізації ВМФ Росії» (сообщил Путин, 2019).

Традиційно російський флот завжди відставав у розвитку від сухопутних сил, що можна легко пояснити тим, що сухопутна територія Росії найбільша у світі, тоді як іiі доступ до океанів ніколи не був настільки ж безпосереднім, як, наприклад, у Сполучених Штатів.

Разом з тим, останне десятиліття виявилося також і часом розквіту для російського флоту. Ця тенденція стала особливо очевидною після анексії Криму й зростання можливостей Росії на Чорному морі.

Все розпочалося з російської морської доктрини 2015 р., у якій акцентовано на розвиток Чорноморського та Азовського флотів, на «прискорену модернізацію й всебічне посилення стратегічного положення 
Російської Федерації при збереженні миру та стабільності в регіоні» (Maritime Doctrine of the Russian Federation, 2015).

Наступний документ від 2017 р., «Основи державної політики Російської Федерації в галузі морських операцій на період до 2030 року», був більш амбітним. Зокрема, він наголосив на необхідності збереження «військово-морських можливостей на рівні, що гарантує стримування агресії проти Російської Федерації з океанів і морів, а також можливість завдати неприйнятної шкоди будь-якому потенційному противнику» (The fundamentals of the state policy of the Russian Federation, 2017). Загалом такі слова, як «ядерне та неядерне стримування», «стратегічна стабільність» та «неприпустима шкода» є найбільш поширеними в документі, їх використовують набагато частіше, ніж у Військовій доктрині 2014 p.

А втім, найбільш цікавою частиною цього документа є заява про готовність використовувати нестратегічну ядерну зброю для деескалації: «Під час ескалації військового конфлікту демонстрація готовності й рішучості в застосуванні нестратегічного потенціалу ядерної зброї $\epsilon$ ефективним стримувальним фактором» (The fundamentals of the state policy of the Russian Federation, 2017). Насправді, цей документ змусив навіть деяких видатних російських експертів визнати офіційну кодифікацію «ескалації для деескалації» або запобіжного ядерного удару (Стефанович, 2020).

Цікавий уривок також можна знайти в «Основах стримування» щодо Чорноморського регіону. Серед «червоних ліній» використання ядерної зброї стаття 19С зазначає : «атаку супротивника на критичні урядові або військові об'єкти Російської Федерації, зрив роботи яких може підірвати дії реагування ядерних сил» (Basic Principles of State Policy of the Russian Federation on Nuclear, 2020). Оскільки Чорноморський флот може брати участь у завданнях «ескалації для деескалації», ми вважаємо, що це підвищує шанси застосування елементів російського ядерного арсеналу в регіоні. Особливо, якщо є загроза територіальній цілісності (або статусу Криму).

Зрештою, складається цікава ситуація, коли поняття «ескалація для деескалації» можна знайти тільки в офіційному документі, присвяченому найменш розвиненому крилу російської стратегічної тріади.

Загалом подібній декларації не бракує намірів переконливості, по-перше, через швидку модернізацію російського флоту з впровадженням новітніх видів зброї, разом з так званою «зброєю першого березня». Ми маємо на увазі чотири види нових стратегічних ядерних озброєнь, 
представлених президентом В. Путіним в його промові до Федеральних Зборів 1 березня 2018 р. 3 чотирьох видів нової зброї два були представлені (i, в основному, тестувалися) для російського флоту. Зокрема, це стратегічний ядерний безпілотний підводний човен «Посейдон», оснащений ядерною зброєю, який колишній співробітник Пентагону Марк Шнайдер назвав «найбільш безвідповідальною ядерною програмою, що Путінська Росія коли-небудь вигадувала» (Stillwell, 2016). Водночас місія «Посейдону» (мета якого викликати цунамі на узбережжі США) до сьогодні не включена до стратегічних завдань флоту, та в основному нагадує «машину Судного дня», i насправді не $\epsilon$ актуальною поза апокаліптичним сценарієм ядерної війни.

Інший вид зброї - «Кинджал» - повітряна гіперзвукова крилата ракета, що, як правило, запускається з літаків-винищувачів МіГ-31К, представляє більш актуальну загрозу в рамках цілей, оголошених Основами ВМФ. Зокрема передбачається, що іiі будуть виготовляти у двох версіях: звичайній та ядерній. Якщо опиратись на думку російського ракетного експерта Дмитра Стефановича, російське сприйняття та місії гіперзвукової зброї досить сильно відрізняються від підходу США. Якщо американці орієнтовані на конвенційні удари високої точності з застосуванням гіперзвукової зброї, «для Росії це означає гарантовану доставку ядерної зброї на потрібні відстані» (Стефанович, 2020). Причиною $\epsilon$ вічний страх росіян, що протиракетна оборона США (в цьому випадку розгорнута європейська) якось підірве можливості російського стратегічного стримування. Тому основне завдання «Кинджала» (треба зважати на високу матеріальну цінність цієї ракети та наявність підтримки методами традиційного стримування - набагато дешевшими ракетами), ймовірно, бути ядерним.

Крім того, однією з майбутніх моделей «суперзброї», призначеної для ВМФ Росії, буде гіперзвукова ракета морського базування «Циркон», яка має бути введена в користування російського флоту у 2022 р. i матиме дальність польоту 500 - 1000 км. «Циркон» планують як зенітну зброю, яку будуть використовувати військові кораблі та підводні човни, і запускатимуть з більшості носіїв, оснащених ракетами «Калібр» (Птичкин, 2019).

Говорячи про російські військово-морські озброєння, розроблені за останнє десятиліття, слід зазначити, що КРМБ «Калібр» викликає серйозне занепокоєння, зважаючи на її успішні випробування Москвою у військових операціях в Сирії. Її не відносять до нової «суперзброї», однак її вважають однією з найефективніших крилатих ракет середньої дальності (до 2500 км.). На думку деяких російських експертів, основ- 
ною тенденцією нинішнього російського флоту є оснащення більшості підводних човнів (28 атомних та 23 дизельних) «Калібрами», що повинно значно збільшити потенційну роль військово-морського флоту в завданні неприйнятної шкоди ворогові (Sinovets, 2018).

Роль російського Чорноморського флоту в стратегічному плануванні Москви

Загальновідомо, що після анексії Криму, Росія перетворила півострів на один 3 найбільш мілітаризованих пунктів регіону - «бастіон російської слави», фортецю російської влади, що проектується у регіоні.

Потенціал озброєнь російського Чорноморського флоту зростає.

По-перше, це наступальний потенціал. Немає сумнівів, що російські стратегічні підводні човни належать до їі Північного та Тихоокеанського флотів, тоді як військово-морські сили інших двох (Балтійський i Чорноморський) складається лише 3 напівстратегічних підрозділів. Тут варто зважати на те, що нестратегічні ядерні сили було особливо відзначено в «Основах ВМС» у контексті загострення військових конфліктів.

Водночас Чорноморський флот Росії має в своєму складі керовані ракети класу фрегат «Адмірал Григорович» (проект 11356) та шість підводних човнів 636,3 класу «Варшав'янка». Всі вони оснащені торпедами, крилатими ракетами і ПКР (Petersen, 2019). Однак, немає ніяких сумнівів у тому, що обидва фрегати цього класу і підводні човни 636,3 було оснащено ракетами «Калібр» протикорабельної та протисубмаринної версії для наземних атак. «Калібр» існує як в ядерній, так і в звичайній версії, і коли він розміщений у Чорному морі, то здатен націлюватися на більшість європейських держав НАТО.

До цього допису ще можна додати крейсер «Москва». Виготовлений в 1970-х рр. як зенітний пристрій, сьогодні він є носієм протикорабельних ракет «Вулкан» 3 дальністю 700 - 1000 км, а також здатний нести ракети ППО С-300 та протисубмаринні торпеди. До того ж 41 бригада складається 3 десяти корветів класу «Тарантул» 3 протикорабельними ракетами П-270 «Москіт», двох корветів на повітряній подушці класу «Дергач» із озброєнням Р-270, корвета «Буян-М», на якому встановлено вісім крилатих ракет «Калібр», і двох старих корветів «Нанучка-III», що виконують підтримуючу функцію до зазначених вище (Roblin, 2018).

По-друге, це оборонна зброя. Зокрема, Москва розгорнула чотири батальйони ракетних комплексів С-400 (ще один додали після російсько-українського інциденту на Каспіі) і також системи «Бастіон», щоб охопити практично все Чорне море. Надзвукові крилаті ракети з проти- 
корабельним реактивним двигуном «Онікс-800» системи «Бастіон», які мають дальність польоту 400 км, дозволяють Росії почуватися досить безпечно в північній частині Чорного моря. Ще там було розгорнуто системи точкової оборони C-300 та «Панцир-С1». Дмитро Горенбург зазначає, що завдяки розгортанню систем C-400 i «Бастіон» Росії вдалося створити зону заборони доступу (anti-access/area-denial zone, A2/AD), яка поширюється майже на все Чорне море. Ця ситуація надає росіянам можливість «стримувати військовий рух до Чорного моря й відмовляти у свободі дій опоненту, якщо він потрапляє у цей театр дій» (Gorenburg, 2018).

Загалом російський Чорноморський флот не має аж надто багато військових кораблів, але має відповідне поєднання наступальних та оборонних озброєнь, що дає можливість для виконання тактичних операцій на кшталт описаних в «Основах ВМС» дій для деескалації.

Військові навчання засвідчили, що не тільки ракети «Калібр», а й стратегічні бомбардувальники та деякі з новітніх видів зброї, такі як ракети «Кинджал», практикували маневри на Чорному морі. Спільні тренування з ракетної стрільби Чорноморського й Північного флотів із запусками з води, повітря та узбережжя вважають безпрецедентними за масштабами. Проведені на півдні та південному заході окупованого Криму спільні навчання включали сорок кораблів, підводний човен, понад сорок літаків та вертольотів (Klymenko, 2020).

Розклад російських військових навчань на 2020 р. не залишив жодних сумнівів у намірах Москви зміцнити цей фланг. Зокрема, на два перші місяці осені у Південному військовому районі Росії заплановано широкомасштабні стратегічні навчання командного пункту «Кавказ-2020». Вони спрямовані на поліпшення координації об'єднаних сил, що виконують широкомасштабну військову операцію в Південному та Південно-Західному «театрах», вони передбачають залучення майже ста лінкорів та допоміжних кораблів із Чорноморського та Каспійського флотів (Klymenko, 2020).

\section{Висновки та сценарії}

Нинішній обсяг та можливості російського Чорноморського флоту не сконструйовані так, щоб вести стратегічну війну. Але цього вистачить для підтримки російської поведінки примусу й навіть для тактичних операцій з деескалації на достатньому рівні. Крім того, головну мету Чорноморського флоту Росії часто описують як «проекція могутності».

Тому основна місія Чорноморського флоту Росії може бути представлена у взаємопов'язаних сценаріях: 
Сценарій 1. Росія використовує Чорноморський флот для проекції могутності/примусу в регіоні

Багато експертів погоджуються з тим, що Росія продовжуватиме використовувати Чорне море як платформу для розширення свого впливу на сусідні регіони, включаючи Балкани, Близький Схід та середземноморські країни. Ми говоримо, насамперед, про військовий вплив. Зі збільшенням кількості кораблів Чорноморський флот поступово стає основною базою для проведення військових операцій у Сирії. Незважаючи на дві військові бази Росії в Сирії, більшість з важливих військових операцій здійснюються за участі Чорноморського флоту та його кораблів, оснащених КРМБ «Калібр», успішно випробовуваних Москвою в сирійському конфлікті.

Іншою функцією є збільшення проекції могутності в Середземномор'ї, де Росія визначає багато загроз не тільки для своєї внутрішньої безпеки, але й для свого впливу на сирійський конфлікт. Інші регіони «майбутньої відповідальності» Чорноморського флоту згадує адмірал Вітко, зокрема «води Червоного моря, Адена та Перської затоки, а також західну частину Аравійського моря, які сьогодні вважаються відповідальністю Тихоокеанського флоту» (Витко, 2017). За експертним аналізом, завдання проекції могутності в регіоні цілком реально виконати. Навіть «з невеликою кількості фрегатів флот буде представляти потенційну загрозу для інших військово-морських сил регіону, включаючи ударні групи американських авіаносців» (Gorenburg, 2018). Для цієї місії необхідна велика кількість надводних лінкорів, що чітко відображається в поточних якісних характеристиках російського Чорноморського флоту. Крім того, враховуючи подвійне призначення зброї «першого березня», можна передбачити, що для Чорного моря вона суттєво посилить стратегію A2/AD.

Зважаючи на те, що основним завданням російського флоту $є$ успішне відпрацювання $\mathrm{A} 2 / \mathrm{AD}$, засноване переважно на традиційному стримуванні, але з урахуванням потенційних ядерних операцій низького рівня, спрямованих на зміцнення стабільності стримування. Цей зв'язок звичайних та ядерних опцій становить загальну основу російського стримування з урахуванням постійної координації військових навчань Чорноморського та Північного флотів.

Створення зони A2/AD у Чорному морі також $є$ потужною платформою для поведінки примусу Росії, що маніпулює загрозою відмови (або суттєвого обмеження) військових навчань НАТО в регіоні. Зрештою це призводить до одвічного занепокоєння, що Москва перетворює Чорне море на «Російське озеро». 
Сценарій 2. Чорноморський флот як засіб оборони і стримування HATO

По-перше, це стримування НАТО від військової експансії на Південний Схід та нейтралізація нової військової інфраструктури, що може загрожувати стримувальним можливостям Росії на Південному фланзі. Зокрема, ми знаємо, що розширення НАТО на Схід та розбудова об’єктів ПРО в Європі належать до «загроз» для російської безпеки в офіційній «Військовій доктрині» від 2014 р. Також російська влада жорстоко розкритикувала розгортання Aegis Ashore у Румунії в 2016 р. Зокрема, президент В. Путін заявив, що система, яка розміщується в Румунії, не оборонна, а $є$ частиною стратегічного ядерного потенціалу США. Тому він згадав у травні 2016 р., що Москва «буде змушена думати про нейтралізацію загроз безпеки Росії» (Putin: Russia will consider tackling NATO missile defense threat, 2016). Виникло декілька причин для занепокоєння. Першою й основною була теоретична та допоки неіснуюча можливість перехоплювачів CM-3 збивати російські ракети в майбутньому. Це все ще розглядалося як потенційна небезпека. Другою причиною для занепокоєння, яка з'явилася пізніше, було припущення російських військових про те, що система СМ-3 Aegis Ashore також може використовуватися для запуску крилатих ракет «Томагавк». Останній факт заперечували американці, коли ще діяв договір РСМД, однак після виходу з нього в серпні 2019 р. США успішно випробували крилату ракету з пускової установки СМ-3. Ця ситуація потенційно робить місцеперебування Aegis Ashore у Румунії не лише предметом майбутнього занепокоєння, але й розглядається росіянами як потенційна наступальна військова інфраструктура Альянсу, особливо в контексті нещодавнього рішення США виробляти ракети середньої дальності для розгортання в Європі. Певно, нинішній склад Чорноморського флоту найкраще відображає такий тип потреб. Зокрема, до анексії Криму росіяни, ймовірно, могли націлюватися на Aegis Ashore лише своїми КРМБ «Калібр», однак захоплення української території значно полегшило б досягнення цієї цілі більш широким асортиментом боєприпасів.

По-друге, анексія Криму зробила Чорноморський флот стратегічно важливішим для Росії. Згадаймо, що в «Основних принципах державної політики Російської Федерації щодо ядерного стримування» 2020 р. Росія офіційно оголосила збереження територіальної цілісності одним з принципів, які є основою для стримування. Це одразу ж піднімає питання Криму, яке може стати причиною для застосування ядерної зброї з метою деескалації у випадку, якщо російське звичайне стриму- 
вання не буде достатньо ефективним, щоб утримати Захід від безпосереднього військового втручання.

Підсумовуючи, можна сказати, що оцінка стратегічного виміру Чорноморського флоту Росії показує: основна увага зосереджена на створенні A2/AD, що надає Росії: а) стійку основу для здійснення примусу в регіоні, частково зменшуючи тут роль Альянсу; б) посилення стримування на Південному фланзі, яке досягається розгортанням сучасної зброї подвійного призначення та підкріплене морською доктриною, що дозволяє тактичні дії для деескалації.

\section{Список посилань}

1. Актуальные задачи развития Вооруженных сил Российской Федерации. (2003). Москва: Министерство обороны РФ.

2. Витко, А. (2017). Черноморский флот: фактор расширения боевых возможностей в зоне ответственности. Взято 3: http://milportal.ru/ chernomorskij-flot-faktor-rasshireniya-boevyh-vozmozhnostej-v-zoneotvetstvennosti/

3. Военная доктрина Российской Федерации. (2010). President of Russia. Взято 3: http://news.kremlin.ru/ref_notes/461

4. Военная доктрина Российской Федерации. (2014) President of Russia. Взято 3: http://static.kremlin.ru/media/events/files/41d527556bec8deb3530. pdf

5. Военная доктрина Российской Федерации. (2000). President of Russia. Взято 3: http://www.ng.ru/politics/2000-04-22/5_doktrina.html

6. Гольц, А. (2019). Репетиция катастрофы. Взято з: HTTPS://WWW. EJ2020.RU/?A=NOTE\&ID $=34300$

7. Стефанович Д. (2019). Военные действия вновь вернулись в инструментарий великих держав. (2020). Бизнес Газета. Взято 3: https:// www.business-gazeta.ru/article/458879

8. Заседания дискуссионного клуба Валдай. (2018). President of Russia. Взято 3: http://kremlin.ru/events/president/news/58848

9. Птичкин, С. (2019). Гиперзвук на подлете. Взято з: https://rg.ru/2019/09/19/ chto-predstavliaet-soboj-giperzvukovaia-raketa-cirkon.html

10. Путин сообщил о модернизации флота из-за угрозы со стороны НАТО. (2019). RBC.ru. Взято 3: https://www.rbc.ru/politics/03/12/2019/5de65ffa9a $7947068 \mathrm{~d} 52 \mathrm{c} 0 \mathrm{~d} 0$

11. Basic Principles of State Policy of the Russian Federation on Nuclear Deterrence. (2020). The Ministry of Foreign Affairs of Russian Federation. Retrieved from: https://www.mid.ru/en/foreign_policy/international_safety/ disarmament/-/asset_publisher/rp0fiUBmANaH/content/id/4152094

12. Gorenburg, D. (2018). Is the New Russian Black Sea Fleet Coming? Or is it here? War on the rocks. Retrieved from: https://warontherocks.com/2018/07/ is-a-new-russian-black-sea-fleet-coming-or-is-it-here/

13. Joint Exercises of Northern and Black Sea fleets. (2020). President of Russia. Retrieved from: http://en.kremlin.ru/events/president/news/62556 
14. Klymenko, A. (2020). Naval Warfare Scenarios for 2020. UA: Ukraine Analytica, 1 (19), 27.

15. Kroening, M. (2018). A Strategy for Deterring Russian Nuclear De-Escalation Strikes. Atlantic Council. Retrieved from: https://www.atlanticcouncil.org/ wp-content/uploads/2018/04/Nuclear_Strategy_WEB.pdf

16. Maritime Doctrine of the Russian Federation. (2015). Russia's Maritime Studies Institute, US Naval War College. Retrieved from: https://dnnlgwick. blob.core.windows.net/portals/0/NWCDepartments/Russia\%20Maritime\%20 Studies\%20Institute/Maritime\%20Doctrine\%20TransENGrus FINAL.pdf?s $\mathrm{r}=\mathrm{b} \& \mathrm{si}=\mathrm{DNNFileManagerPolicy} \& \mathrm{sig}=\mathrm{fqZgUUVRVRrKmSFNMOj} \% 2 \mathrm{FNa}$ RNawUoRdhdvpFJj7\%2FpAkM\%3D

17. Nuclear Posture Review Final Report. (2018). U.S. Department of Defense. Retrieved from: https://media.defense.gov/2018/Feb/02/2001872886/-1/1/1/2018-NUCLEAR-POSTURE-REVIEW-FINAL-REPORT.PDF

18. Oliker, O., \& Baklitskiy, A. (2018). The Nuclear Posture Review and Russian De-Escalation: A Dangerous Solution to an Non-Existent Problem. War on the Rocks. Retrieved from: https://warontherocks.com/2018/02/nuclear-posturereview-russian-de-escalation-dangerous-solution-nonexistent-problem/

19. Petersen, M. (2019). The Naval Power Shift in the Black Sea. War on the Rocks. Retrieved from: https://warontherocks.com/2019/01/the-naval-powershift-in-the-black-sea/

20. Putin: Russia will consider tackling NATO missile defense threat (2016). Retrieved from: https://www.rt.com/news/342915-putin-nato-threat-missiles/

21. Roblin, S. (2018). Introducing Russia's 5 Deadliest Warships in the Black Sea. National Interest. Retrieved from: https://nationalinterest.org/blog/buzz/ introducing-russias-5-deadliest-warships-black-sea-37677

22. Sinovets, P. (2018). How Russia's Nuclear Buildup Offers a Good Opportunity for Renewed Arms Control Dialogue. PONARS Eurasia. Retrieved from: http://www.ponarseurasia.org/memo/how-russias-nuclear-buildup-offersgood-opportunity-renewed-arms-control-dialogue

23. Sinovets, P. (2019). Escalation for De-Escalation? Hazy Nuclear-Weapon "Red Lines" Generate Russian Advantages. PONARS Eurasia. Retrieved from: http://www.ponarseurasia.org/memo/escalation-de-escalation-hazynuclear-weapon-red-lines-generate-russian-advantages

24. Stillwell, B. (2016). Russia's powerful new submarine nuke drone is a coastal killer. Retrieved from: https:/www.wearethemighty.com/articles/russiansuperweapon-is-a-submarine-nuke-delivery-drone

25. The Fundamentals of the State Policy of the Russian Federation in the Field of Naval Operations for the Period until 2030. (2017). Russia's Maritime Studies Institute, US Naval War College. Retrieved from: https://dnnlgwick. blob.core.windows.net/portals/0/NWCDepartments/Russia\%20Maritime\%20 Studies\%20Institute/RMSI_RusNavyFundamentalsENG_FINAL\%20(1).pdf ?sr=b\&si=DNNFileManagerPolicy\&sig $=$ fjFDEgWhpd 1 ING\%2FnmGQXqa H5\%2FDEujDU76EnksAB\%2B1A0\%3D

26. Ven Buusgaard, K. (2018). The Myth of Russia's Lowered Nuclear Threshold. War on the Rocks. Retrieved from: https://warontherocks.com/2017/09/themyth-of-russias-lowered-nuclear-threshold/ 


\section{РОЗДІЛ 5}

\section{ПОЛІТИКА ЄС ЩОДО ЧОРНОМОРСЬКОГО РЕГІОНУ: КОНФЛІКТ ІНТЕРЕСІВ, ВІДПОВІДАЛЬНОСТІ ТА ЗАГРОЗ}

(Максименко I. В.)

\section{Bcmyn}

3 античних часів Чорне море $є$ своєрідним хабом, де перетинаються інтереси та шляхи великих та малих гравців. Поширення культури, міжнародна торгівля, міграційні потоки та боротьба за стратегічний контроль над регіоном - ці та інші чинники століттями зберігали важливість Чорноморського регіону (ЧР) для Європи. Втім, під владою Османської, потім і Російської імперії, які перетворювали його на внутрішнє море, ЧР набув периферійного статусу у світовій та європейській політиці. Припинення блокового протистояння та розпад СРСР відкрило для Свропейського Союзу (СС) шлях до регіону, а країнам Чорного моря - до об'єднаної Свропи.

У 1990-х рр. ЄС став однією з ключових сил, яка впливала на трансформацію регіону, що пов'язано з такими чинниками: по-перше, євроінтеграційні наміри посткомуністичних країн Чорноморського регіону створили умови для розбудови системи відносин між регіоном та Свросоюзом. По-друге, зі зміною міжнародної системної конфігурації ЄС заявив про готовність взяти на себе відповідальність за мир та об'єднання розділеної Європи, за демократизацію та розвиток своїх народів. В цьому контексті потенціал Чорноморського регіону у сфері транспортно-транзитної та енергетичної комунікації розглядався як важлива ланка європейської економіки та торгівлі. По-третє, увага з боку СС до регіону пов'язана з наявністю чинників, що негативно впливають на регіональну, а отже й загальноєвропейську безпеку (зокрема, конфлікти, економічні кризи, політична нестабільність, організована злочинність). Географічна близькість та двостороннє співробітництво між СС та окремими країнами регіону, що динамічно розвивалося, поступово створили численні канали, якими до Європи проходять хвилі нестабільності та загроз. Нарешті, з інтеграцією Болгарії та Румунії до Свросоюзу за комплексом політичних, економічних та стратегічних критеріїв СС стає одним з найвагоміших економічних та політичних гравців Чорноморського регіону. Дві з чорноморських країн $є$ його членами, а інші, зокрема Греція, Польща та країни Балтійського регіону, зацікавлені в посиленні ролі ЄС в розширеному Чорноморському регіоні. Крім того, він підтримує двосто- 
ронні зв'язки з усіма країнами регіону, серед яких Україна, Молдова та Грузія підписали Угоди про асоціацію та створення ЗВТ; Туреччина та ЄС поєднані Митним союзом та відкритим переговорним процесом про членство, а Росія визнана стратегічним партнером ЄС. Взаємозв'язок між $Є С$ та регіоном посилюється завдяки тому, що $Є С$ є найбільшим торговельним та інвестиційним партнером для усіх країн ЧР, тоді як СС отримує більше $34 \%$ природного газу та нафти з регіону (загалом від Pociï та Азербайджану). Згідно з показниками Eurostat у 2018 р. частка ЄС торговельного балансу Молдови складала 50 \% 4,7 млрд. євро), Грузії - 30 \% (2,8 млрд. євро), України - більше 40 \% (40,1 млрд. євро), Туреччини - 43 \% (153,4 млрд. євро), Росії - майже 43 \% (253,6 млрд. євро). ЄС є найбільшим інвестиційним партнером України, Туреччини та Росії: у 2017 р. Україна отримала від СС інвестиції на суму 12,9 млрд. євро, Туреччина - 88,2 млрд. євро, а Росія - 299,7 млрд. євро.

Однак чи можна вважати, що сьогодні $€ С$ дійсно є активним суб'єктом регіональної системи міжнародних відносин, що він демонструє стратегічний підхід до регіону, несе відповідальність за розвиток регіону як інтегрованої частини Свропейського континенту, про що було зазначено у Стратегії СС щодо Чорного моря? Для того, щоб відповісти на ці питання, варто пригадати, як формувалася політика СС щодо Чорноморського регіону, визначити, в чому полягали його інтереси, які чинники визначають результативність політики СС з урахуванням поточної ситуації в регіоні.

\section{Оформлення підходів СС до Чорноморського регіону}

Першим етапом формування політики СС щодо ЧР можна вважати підписання продовж 1994 - 1999 рр. Угод про партнерство та співробітництво з країнами, що утворилися після розпаду СРСР - Білоруссю, Україною, Молдовою, Росією, Грузією, Вірменією та Азербайджаном. Ці двосторонні документи створили фундамент для подальших відносин між Євросоюзом та кожною країною. Вони містили тезу про наміри ЄC сприяти регіональному співробітництву між сусідніми країнами 3 метою розвитку та стабільності регіону. А також ініціатив для поглиблення співробітництва та взаємної довіри між незалежними сусідніми країнами.

Наступним кроком можна вважати прийняття Комунікації про регіональне співробітництво в Чорноморському регіоні у 1997 р., в якій ЄС вперше офіційно задекларував важливість ЧР для об'єднаної Свропи. В документі зазначалося, що, визнаючи зростаюче стратегічне значення Чорного моря для Свросоюзу, Комісія висловила «намір розробити нову стратегію регіонального співробітництва», спрямовану на просування 
взаємодії у сфері транспорту, енергетики, торгівлі. Це сприяло б екологічно стійкому розвитку, зокрема, в правосудді та внутрішніх справах. Наступним кроком у цьому напрямі став розгляд в Свропейському Парламенті можливості створення спільноти «Європейський Союз - Чорномор'я». Однак пізніше про ЧР майже не згадували.

Навіть у Свропейській стратегії безпеки 2003 р. йшлося лише про реалізацію політики безпеки СС з метою розбудови безпеки в сусідніх 3 Європою регіонах. Окремо лише зазначалося про важливість створення кола стабільних країн на Схід від СС шляхом стимулювання економічної та політичної кооперації східних сусідів. Подібна думка була закріплена в Комюніке «Розширена Свропа - нові сусіди: нова система стосунків 3 нашими східними та південними сусідами» 2003 р., в якому передбачалося формування «кола друзів» уздовж південного та східного кордонів $€ \mathrm{C}$, об'єднаних спільними цінностями, відкритими ринковими відносинами і кордонами, а також посиленням співпраці в таких важливих сфеpax, як транспорт, енергетика, екологія, запобігання конфліктів.

Попри заявлені у 1997 р. наміри ЄС не зміг приділити належної уваги чорноморському вектору, на чому наголошували під час засідання Європейського Парламенту у січні 2008 р.: «Парламент не задоволений прогресом, досягнутим після < ..> 1997 року, і закликає до справжнього регіонального виміру щодо цього простору, з конкретними пропозиціями щодо сприяння регіональній співпраці» та створення зони вільної торгівлі в регіоні (MEPs speak, 2008).

Причини низької оцінки тогочасної політики СС щодо ЧР полягають, насамперед, у зосередженні всієї уваги на процесах внутрішньої трансформації $€ C$, вирішенні дилеми «поглиблення vs. розширення» та пошуку власного місця в постбіполярному світі. Але $С$ С тоді не був здатний заглядати далеко за існуючі кордони об'єднання. Не сприяли швидкому формуванню стратегічного підходу, що мав відображати спільний інтерес та політичну волю всіх членів СС (а це були тільки західноєвропейські країни) і суперечливі погляди на стратегічну важливість регіону для Європи. Так, до трагічних подій 11 вересня 2001 р. Чорне море залишалося, за словами Р. Асмуса та Б. Джексона, «цивілізаційною чорною дірою» у західній історичній свідомості (Asmus\&Jackson, 2004). Потенційна важливість регіону як транзиту енергоресурсів з Каспію, загрози від неврегульованих конфліктів в Молдові та країнах Південного Кавказу, обмеженість ринків цих країн, за оцінками Б. Коппітерса, значно поступалися балканським проблемам (Coppieters, 2003, с. 164). Крім того, СС тільки визнав необхідність перетворення Свросоюзу на стабілізуючий фактор і модель в новому, багатополярному світі (Laeken 
Declaration, 2002). Тож очікувати швидких результатів було дійсно зарано.

Ситуація починає трансформуватися після 2004 р. По-перше, завдяки розширенням у 2004 та 2007 рр. утворилося східноєвропейське лобі у складі Польщі, Румунії, Болгарії. По-друге, демократичні та проєвропейські революції в Грузії та Україні розглядалися як виклики для засадничих принципів $\mathrm{CC}$, що вимагало від офіційного Брюсселя відповідної реакції. По-третє, поширення економічних та енергетичних інтересів СС у напрямку Каспійського регіону та Близького Сходу посилило енергетично-транзитне значення регіону. Нарешті, в умовах поширення терористичної небезпеки ЧР виступав одночасно як буфер та партнер ЄС і НАТО у протидії поширенню ісламістської загрози. Отже, під тиском зазначених чинників чорноморський вектор таки опинився на порядку денному європейської політики.

Першим досягненням стало прийняття документа «Чорноморська синергія - нова ініціатива регіонального співробітництва» (2008р.), що став декларацією загальноєвропейського бачення регіону та позиції $\mathrm{CC}$ щодо регіональних процесів і головних принципів його діяльності в регіоні з врахуванням спільних інтересів Союзу та країн регіону. Це був важливий етап у формуванні політики $\mathrm{CC}$ щодо регіону, яка, за словами А. Шокенхоффа, депутата Бундестагу, мала стати «каталізатором та якорем для регіональної співпраці між країнами» регіону (Schockenhoff, 2007, с. 4). Така двоякість програми пов'язана з тим, що вона, з одного боку, визначала ключові сфери для посилення регіональної співпраці, а з другого - намагалася стимулювати реформи в політичній та економічній сферах країн регіону, підтримувати стабільність та сприяти зростанню, впроваджувати проекти, які потребують практичних зусиль у регіоні, та, якщо можливо, створити заохочувальну атмосферу для вирішення конфліктів у регіоні.

Однак європейські держави не зробили цей регіон пріоритетним, а також не визначили його стратегічних завдань. Заклики зі сторони найбільш зацікавлених країн, особливо Румунії, Болгарії, Греції, приділяти більше уваги «новому сусіду» - Чорноморському регіону, виробити послідовну та більш координовану політику $Є С$ не були почутими.

Невдоволення чорноморських країн-членів СС «доволі обмеженими результатами» Чорноморської синергії, «відсутністю достатнього прогресу та невідповідності очікуванням» вилилося в прийнятті Резолюції Європарламенту про Стратегію СС стосовно Чорного моря у 2011 p. (Los Fayos, 2013, c. 4-5). Документ став відповіддю не тільки на незадоволення результатами політики Чорноморської синергії, але й на 
нову геополітичну ситуацію в регіоні на тлі низької ефективності ЄПС та Східного Партнерства (СхП). Свропейський Парламент закликав до розробки «інтегрованої стратегії СС щодо Чорного моря», яке, по-перше, з 2007 р. стало внутрішнім європейським морем та зоною відповідальності ЄС в сфері забезпечення миру, демократії, безпеки, стабільності, регіонального співробітництва та усталеного процвітання; по-друге, $\epsilon$ мостом, що з'єднує Європу з Каспійським морем, Центральною Азією та Близьким Сходом, а надалі і з Південно-Східною Азією та Китаєм, i характеризується не тільки тісними зв'язками й великим потенціалом, але й протиріччями та суперництвом, що ставить перед зовнішньою політикою та політикою безпеки СС нові завдання. Отже, Стратегія чітко визначила гостру необхідність посилення політичної присутності $€ \mathrm{C} \mathrm{у}$ регіоні.

Одним з таких завдань виявилися наслідки «Арабської весни», що охопила країни Південного Середземномор'я та Сирію. Політичні кризи в цих країнах супроводжувалися масовими протестами, а у Сирії та Лівії переросли в громадянські війни, наочно продемонстрували неефективність регіональної політики $€$, заснованої на ЄПС. Аналітики вказували на потенційну можливість поширення соціально-політичної кризи на країни Південного Кавказу та Каспійського регіону з посиленням сепаратистських настроїв, загостренням існуючих протиріч та конфліктів, виникненням нових вузлів протистояння тощо. Дестабілізація ситуації в Середземномор'ї та масова неконтрольована міграція з країн Близького Сходу до ЄС викликали нову хвилю дискусій щодо важливості Чорноморського регіону в безпековому вимірі. У результаті ЄС переглянув ЄПС та ініціативу СхП, збільшивши фінансування програм та впроваджуючи більш диференціальний підхід до учасників політики.

Найпотужнішим викликом для регіональної політики СС стала анексія Криму та подальша політична діяльність Російської Федерації зі встановлення повного контролю над регіональними процесами шляхом нарощування військової присутності. Швидка мілітаризація Кримського півострова та збільшення контингенту ВМС РФ в Чорному морі суттєво змінили баланс сил, зменшили і так невисокий рівень довіри та поглибили загрози системі безпеки в Свропі.

Реакція $\mathrm{CC}$ на події в регіоні відображена у Звіті про стратегічну військову ситуацію в басейні Чорного моря після незаконної анексії Криму Росією (травень 2015 р.), в якому Євросоюз визнав негативні зміни в ЧР через дії Росії, що надалі активізують проекцію сили поза російською територією, зокрема здійснюючи тиск на східні кордони $Є \mathrm{C}$ - Румунію, Польщу, країни Балтії. Це поглиблює ризики та загрози для 
всього Чорноморського регіону, що вже відобразилося на співробітництві в таких важливих сферах, як управління кордонами та міграційний контроль, торгівля людьми та боротьба з організованою злочинністю. Отже, СС закликав переглянути базові документи (Свропейську стратегію безпеки, Європейську стратегію морської безпеки, Стратегію СС щодо Чорного моря, СПС) з метою створення «сміливого та орієнтованого на результат підходу, особливо у сферах економіки, оборони та безпеки, внутрішнього зміцнення СС, оновлення та вдосконалення інструментів, що вже існують, а також посилення реакційного потенціалу Союзу на розвиток подій в сусідньому регіоні» (Report, 2015, с. 7). Однак основою політики СС у регіоні залишалася Чорноморська синергія, яка на той час визнавалася «фактично призупиненою» (Report, 2015, с. 9).

Сьогодні позиція $С С$ щодо безпосередньої зацікавленості як країн регіону, так і ЄС у «стабільному, безпечному, стійкому і процвітаючому Чорноморському регіоні», а отже реалізація конструктивної ролі і відповідальності $Є С$ щодо розвитку потенціалу басейну Чорного моря не змінилася (Black Sea, 2019, с. 15). Однак не відбулося і кардинальної зміни підходу $\mathrm{CC}$ до Чорноморського регіону. Чорноморський вектор політики Євросоюзу як і раніше характеризується інклюзивністю та $є$ комплексом внутрішніх стратегій і документів $С$, двосторонніх договорів 3 країнами регіону, регіональних ініціатив, програм та інструментів $Є С$, що спрямовані, як правило, на реалізацію власних інтересів Євросоюзу, які можна згрупувати так:

1. Демократичний розвиток, верховенство права та політична рівновага як важлива передумова для безпеки та стабільності в регіоні, посилення взаємної довіри та мирного вирішення протиріч, що реалізуються за допомогою Східного Партнерства, Конференції регіональних та місцевих влад країн СхП; Парламентської Асамблеї EURONEST, Свропейського інструмента сусідства і партнерства (СICП).

2. Стійкий економічний розвиток як інструмент для зближення різноманітних економічних режимів в регіоні, покращення інвестиційного клімату та створення додаткових механізмів для регіональної взаємодії з перспективою на створення надалі простору вільної торгівлі 3 країнами Чорного моря. В основному, цей напрямок реалізується через двосторонні торговельно-економічні відносини СС з країнами ЧР, діяльності Митного союзу СС - Туреччина та окремі ЗВТ між ЄС та Україною, Молдовою, Грузією в межах Угод про асоціацію, а також на рівні ЄС - ОЧЕС. Чималу увагу приділяють проектам транскордонного співробітництва в межах ЄІСП та Стратегії ЄС для Дунайського регіону 2010 р., спрямованих на стимулювання розвитку прикордонних районів, 
належному управлінні на кордонах, розвитку туризму з урахуванням багатого культурного та етнічного різноманіття регіонів.

3. Енергетична безпека $\epsilon$ важливим напрямом для $\Theta C$, який реалізує ряд проектів щодо модернізації та розвитку енергетичної інфраструктури (Інтерконнектор Азербайджан-Грузія-Румунія (AGRI), Болгарія-Румунія-Угорщина-Австрія (BRUA), Словакія-Угорщина-Румунія-Болгарія «Eastring», обговорюються проекти за участі України та Румунії, зокрема, Tranzit I Ісакча-Негру Воде та Tranzit II Орлівка-Ісакча, які після модернізації з'єднають газопроводами Чорне море та Грецію), диверсифікація постачання енергоресурсів з Каспійського регіону та Центральної Азії в межах програми INOGATE, будівництво LNG-терміналів, впровадження транспарентної та рівноправної енергетичної політики в межах діяльності Енергетичного Союзу.

4. Транспортні та комунікативно-транспортні коридори є важливим елементом розвитку сучасної економіки, які підтримуються 3 боку СС програмами TRACЕКА та Транс'європейських транспортних мереж (TEN-T), транс'європейських транспортних коридорів, особливо № 4, 7, 8 та 9, а також в рамках проектів Інтегрованої морської політики ЄС 2007 р., Транспортної стратегії ЄС до 2050 р. та Стратегії ЄС для Дунайського регіону, який вважають воротами СС до Чорного моря, Південного Кавказу та Центральної Азії. Зокрема, ЧР відводиться роль мосту у сфері морського транспорту в Спільній Комунікації щодо поєднання Свропи та Азії - Будівельні блоки Стратегії СС (2018 p.) (Black Sea, 2019, c. 13).

5. Запобігання кризам та врегулювання конфліктів, посилення здатності країн ЧР протидіяти організованій злочинності також є одним $з$ пріоритетних напрямів діяльності $€ С$ в ЧР. Відповідно до власної природи $\mathrm{CC}$ спрямовує зусилля на реформування сектору безпеки та поступову трансформацію конфліктного середовища шляхом економічної та соціальної комунікації, відкриття спеціальних місій в Молдові (EUBAM), Грузії (EUJUST Themis та EUMM), Україні (EUAM), надання консультативної та технічної допомоги з реформування законодавчої системи та сектора безпеки, а також через інструменти СхП, Спільних операційних програм ЄICП, зокрема, «Басейн Чорного моря» тощо.

Основні проблеми та виклики реалізації політики СС у ЧР

Усі зазначені ініціативи, проекти та інструменти СС щодо ЧР спрямовані на трансформацію характеру регіональних відносин, на перетворення його з регіону конкуренції на простір співробітництва. Тобто, можна говорити про те, що СС намагався реалізувати власну формулу побудови «миру через інтеграційний проект» (Tocci, 2011), в якому 
країни з різними рівнями розвитку, зі спільними, хоча й конкуруючими інтересами, здатні подолати протиріччя та об'єднатися задля кращого майбутнього для всіх. Втім, наскільки чорноморська політика $Є С$ відображала інтереси об'єднаної Європи та країн регіону? Чи змогла вона досягти цілей, зазначених у проектах та стратегіях, поєднати спільне та відмінне задля загального миру та розвитку?

Відповідь криється у співвідношенні слабких та сильних сторін політики ЄС щодо ЧР з урахуванням об'єктивних та суб'єктивних факторів.

В основі політики $\mathrm{CC} €$ принцип підтримки реформ у країнах, охоплених ЄПС та СхП, задля поступового вирівнювання систем регуляції міжнародного співробітництва та економічних показників країн-партнерів, що мало сприяти рівноправній участі в регіональних проектах. Інші ініціативи та інструменти СС було спрямовано на практичну підтримку розвитку та покращення координації регіональних процесів у тісній кооперації з інституціями та країнами-членами СС. За умов досягнення завдань ЄПС, СхП та інших проектів у поєднанні з Чорноморською синергією очікувалося формування ефективного багатостороннього співробітництва для протистояння регіональним викликам та загрозам. Це в сукупності відповідало задекларованим інтересам усіх країн регіону.

Однак реальні інтереси окремих держав, зокрема Росії та Туреччини, що вбачали в СС конкурента їхньому регіональному статусу та навіть загрозу національним інтересам, за висловлюванням Д. Тріандафіллу, обмежили «сили СС, що трансформують» (Triantaphyllou, 2014, c. 287). Дійсно, Чорноморський регіон - це регіон, який не має чітко сформованої регіональної ідентичності, а учасники відрізняються політичною культурою, військовим потенціалом, рівнем економічного розвитку, зовнішньополітичними та внутрішніми інтересами. Така дивергенція створила низку паралельних процесів в регіоні: «інтеграція, регіональна кооперація (або їх недостатність) і політичне блокування» (Тріандафіллу, 2011, с. 48). Так, інтеграція з СС мала певний позитивний результат та вплив на соціально-культурні зв'язки країн, що мають спільну, проте складну історію. Крім того, вона привнесла додаткові можливості для іншого процесу - регіонального співробітництва, динаміка якого не відповідала можливостям та потребам країн регіону. Разом 3 тим російські інтеграційні проекти - СНД, ОДКБ - вступали в протиріччя з європейськими структурами, особливо з НАТО, які відповідно до заяв російських експертів, є загрозою для національних інтересів Росії (Глазова, 2012; Заквасин \& Комарова, 2020). 
Щодо регіональної кооперації, то жодна зі структур чи ініціатив чорноморських країн - ОЧЕС, ОДЕР - ГУАМ, БЛЕКСІФОР або Чорноморська гармонія - не перетворилися на ефективні інструменти економічного розвитку та багатостороннього співробітництва. Відсутність реального підгрунтя визначило появу радше формальних об'єднань в регіоні, не здатних досягти суттєвих результатів. Не дивно, що у 2014 р. peгіональне співробітництво занепадало. В СС зазначали, що «регіональні безпекові ініціативи БЛЕКСІФОР та Чорноморська гармонія на сьогодні $\epsilon$ паралізованими» (Report, 2015, с. 7). Навіть ОЧЕС, яка була однією 3 найперспективніших платформ для регіонального діалогу, впала в летаргію через кризу довіри в регіоні (Гончар, Мартынюк, Ковалева, 2020). Нині призупинено реалізацію транспортного проекту «Чорноморське кільце», незрозумілим здається впровадження проектів з розвитку морської інфраструктури та магістралей. Як зазначив віце-прем'єрміністр з економічного розвитку й торгівлі Степан Кубів на саміті ОЧЕС (травень 2017 р.): «...як можна прокладати дорогу через окуповану територію та що робити з окупованими портами?» (Віце-прем'єр України, 2017). Важливо в цьому аспекті брати до уваги такі факти: у відповідь на слова С. Кубіва російські представники заявили, що реалізація проекту затримується через неузгодженість маршруту між Україною, Молдовою та Румунією (Борьба за мир, 2017). Однак відповідний документ було підписано міністрами цих країн ще у квітні 2014 р.. В ньому зазначено, що сторони визначили такі два напрямки Чорноморської траси: від Одеси до Бухареста через Рені - Джурджулешти - Галац та від Одеси до Бухареста через Кишинів- Унгени (The Black Sea Ring, 2014). Станом на початок саміту ОЧЕС у Стамбулі у травні 2017 р. учасники проекту перебували на різних стадіях реалізації своєї частки Чорноморської кільцевої автомагістралі (Black sea countries, 2016).

Наступним фактором, що має безпосередній вплив на обмеженість успіху СС в регіоні, є не тільки кількість документів щодо ЧР, а й той факт, що декларації, резолюції, стратегії та інше - усе це видають різні інституції СС. На рішення, відображені в документах, впливають уподобання тих країн, що в той чи інший час головують у цих європейських структурах. Я. Цантуліс наголошував, що завдання посилити роль $С С$ у вирішенні чорноморського «складного геополітичного пазлу» перебувало в площині маргінального інтересу (Tsantoulis, 2009, с. 253). На це вказував і Д. Тріандафіллу: поспіх, з яким СС приймав ЄПС, Чорноморську синергію та СхП, «не завжди допомагав СС виробити чіткий підхід до Чорноморського регіону, оскільки подальша політика здається швидше наслідком зовнішньополітичних прерогатив окремих країн-у- 
часниць, ніж складовою єдиного підходу до регіону» (Тріандафіллу, 2011, с. 49). Дійсно, намагання окремих країн-членів СС (в основному, Франції, Німеччини, Італії, Угорщини, Чеської Республіки) уникнути загострення відносин з Росією через тісні торговельно-економічні зв'язки або енергетичну залежність призводили до заморожування процесів європейської та євроатлантичної інтеграції України, Молдови та Грузії, які $\epsilon$ чорноморськими країнами. Виявилось це й у тривалому дистанціюванні СС від активного залучення до врегулювання довготривалих сепаратистських конфліктів етнічного, стратегічного та терористичного характеру, які перетворили ЧР на «безпековий вузол першочергового значення» (Кіфу, 2011, с. 42-43). Це також не сприяло ставленню до СС як до ефективного гаранта безпеки та миру в регіоні.

Доцільно зазначити, що основні етапи формування політики СС щодо Чорного моря пов'язані із зовнішніми процесами: терористичні атаки на США, Велику Британію та Іспанію, російсько-український газовий конфлікт 2006 р., російсько-грузинська війна 2008 р. тощо. 3 одного боку, це посилювало увагу СС до безпеки та стабільності ЧР, його готовності брати на себе відповідальність за попередження виникнення нових розмежувальних ліній, поширення конфліктів, за підтримку усталеного розвитку задля миру та добробуту. А з іншого - процеси збільшували концентрацію країн СС саме на внутрішніх процесах та посиленні внутрішньої безпеки. Відсутність переконливого обгрунтування щодо більш активної ролі СС в ЧР, яке було б привабливим та зрозумілим для еліт і громадськості віддалених членів Союзу, не залишала ресурсів та політичної волі для формування ані стратегічного підходу, ані інституційного modus operandi. К. Уівер та К. Хендерсон вважають невідповідність між здатністю ЄС узгодити ресурси та інструменти з очікуваннями, що існують в середині та поза межами $Є С$, одним з головних недоліків європейської політики в регіоні (Weaver \& Henderson, 2010, с. 31). I хоча підхід до ЧР характеризують як «незграбний», він і досі має значні ресурси, що робить його привабливим, - додають дослідники. 3 іншого боку, ця привабливість допомагає Союзу підтримувати таке враження доти, доки він може діяти більш ефективно (Weaver \& Henderson, 2010, c. $32-33)$.

\section{Перспективи політики СС щодо ЧР}

Сьогодні є очевидним, що попри наявні інтереси та існуючі політичні, економічні та гуманітарні важелі, СС не зміг подолати негативні тенденції Чорноморського регіону. Свропейські цінності та норми, які розглядали як базис для реформування країн регіону та їхнього зближення, перетворення його на зону кооперації та взаємодії, посилили по- 
літичні відмінності між ними та, як наслідок, спровокували повернення геополітичного протистояння між демократичною (СС і НАТО) та авторитарною (Росія) системами. Критично оцінюючи результати європейської політики, аналітики вказують на необхідність для СС враховувати новий стратегічний ландшафт регіону та розробити нову стратегію для Чорноморського регіону (The Black Sea, 2017; Acikmese \& Triantaphyllou, 2014).

У сучасній ситуації ЄС опинився перед складною дилемою: як, опираючись на інструменти «м'якої» сили, забезпечити власні інтереси та виконувати зобов'язання перед партнерами в умовах гібридної протидії Росії, відповідь на які визначатиме статус ЄС в регіоні у майбутньому.

Неоімперська політика Росії в Чорноморському регіоні породжує серйозні загрози для інтересів Євросоюзу. По-перше, військово-політичне домінування дозволить Кремлю впливати на країни регіону: наприклад, на Україну та Грузію - 3 метою дестабілізації внутрішньої ситуації та затримання темпів зближення з європейськими структурами; а на Болгарію та Туреччину задля обмеження присутності НАТО в Чорному морі. По-друге, опираючись на силу, Росія створюватиме сприятливі умови для реалізації власних енергетичних, економічних, інфраструктурних проектів не тільки в ЧР, але й далі на схід. Наприклад, аналітики передбачають, що Росія може повторити свої акції з переслідування українських кораблів та блокування портів щодо румунських чи болгарських чорноморських платформ, враховуючи, у 2014 р. Москва в односторонньому порядку розширила виключні економічні зони (Celac, Dibenedetto \& Purcăruş, 2019, с. 11). Про таку можливість говорить і генерал Б. Ходжес: Росія намагається дестабілізуючими діями в Чорному морі встановити повний контроль і максимально зменшити можливості інших країн регіону, блокуючи роботу українських портів у Бердянську, Маріуполі, Одесі та перешкоджаючи будівництву глибоководного порту в грузинському місті Анаклія (Ившина, 2020).

Крім загроз, пов'язаних з реалізацією європейських енергетичних та транспортних проектів, зростає загроза в безпековій площині. Так, українські та румунські експерти говорять про зміну безпекової конфігурації Дунаю через політику Росії в Чорному морі та посилення напруги у відносинах СС з Туреччиною. У разі обмеження або закриття Туреччиною судноплавства через Босфор, Дунай $є$ альтернативним шляхом до Чорного моря для європейських військово-морських сил. Водночас зросла роль Дунаю як каналу, через який в Європу можуть потрапляти загрози. 
Румунія, яка є придунайською й чорноморською країною, виступає одним з найбільших лобістів посилення уваги до проблем Чорного моря. Ще до повноправного членства в ЄС Румунія брала участь в розробці Чорноморської синергії, наголошуючи на важливості для СС приділяти більше уваги «новому сусіду» - «Чорноморському регіону» та реалізовувати більш послідовну та координовану політику (Angelescu, 2011, c. 128-130). Бухарест розглядає «Чорноморську синергію» як важливий елемент ЄПС для реалізації багатосторонніх проектів і створення зони безпеки та довіри в ЧР. Сьогодні Румунія використовує всі можливі платформи для протидії агресивній російській політиці в Чорному морі, яка $є$ загрозою на східних кордонах Румунії та $Є C$, i може спричинити відкриті конфлікти поблизу румунського кордону (Веремій \& Паламарчук, 2020, с. 22) або призвести до ізоляції країни (Preventing Romania's, 2016).

Основним напрямом є співпраця Бухаресту 3 країнами-партнерами по НАТО (Болгарія, Греція, Туреччина) а також з Україною з метою посилення безпеки в Чорному морі. Основну увагу приділяють проведенню міжнародних військо-морських навчань («Riverine-2018», «Riverine-2019», «Platinum Eagle-2019», запланованих на кінець вересня «Riverine-2020»). Серед завдань цих навчань $\epsilon$ відпрацювання спільних дій щодо безпеки цивільного судноплавства, проведення операції з моніторингу та підтримки безпеки на Дунаї.

Крім того, Румунія ініціює й активно підтримує нові платформи 3 регіонального та міжрегіонального співробітництва. Зокрема, тут варто нагадати про «Бухарестську дев'ятку» та «Тримор'я», що, за задумом румунської сторони, мають сприяти синергії між національними інтересами країн, які належать до них, регіональними процесами та політиками СС з метою покращення складного безпекового середовища в Чорному морі (Mureșan \& Georgescu, 2017). Виконуючи обов'язки головуючого в ОЧЕС впродовж 2020 р., Румунія прагне посилити політичну та фінансову участь ЄС у Чорноморському регіональному співробітництві, встановити гнучку, орієнтовану на результати та більш тісну взаємодію між ОЧЕС та ЄС в інтересах усіх країн-членів цих об'єднань та регіонального співробітництва загалом (Priorities of the Romanian, 2020).

Продовжує Бухарест лобіювати чорноморський напрямок і в інститутах ЄС. Так, під час свого головування в Раді ЄС в першій половині 2019 р. Румунія зосередила увагу на посиленні регіонального співробітництва на Чорному морі в рамках Чорноморської синергії та реалізації регіональних проектів для стійкого економічного розвитку. Бухарест виступає за більшу координацію Чорноморської синергії з іншими політи- 
ками та стратегіями Союзу, які належать або пов'язані з ЧР, суттєвий перегляд цілей $С С$ та його політики щодо регіону з метою підвищення «видимості роботи ЄС та його держав-членів» (Council Conclusions, 2019).

В цьому контексті надзвичайної актуальності набуло ще одне зі слабких місць чорноморської політики $Є С$, що в умовах тиску з боку Росії перетворюється на серйозну загрозу суб'єктності Євросоюзу в регіоні - відсутність узгодженої позиції всіх членів СС щодо посилення стратегічного підходу до ЧР. Зосередженість на проектах з екології, транспорту, судноплавства, людських контактів, безперечно, є важливими елементами регіонального розвитку, але не відповідає ні інтересам, ні цілям СС, задекларованим у численних документах об'єднання, зокрема, встановленню глобального порядку, заснованого на нормах та правилах, як проголошено у Глобальній стратегії СС 2016 р. Я. Цантуліс (2009, с. 254) висловлював сумніви щодо здатності економічного розвитку через концепцію регіоналізму стати каталізатором політичних реформ, майбутнього процвітання та стабільності в умовах геополітичної конкуренції. Сучасна ситуація демонструє, що ЧР став простором, в якому міжнародні відносини трансформувалися від ліберального порядку до повернення ревізіонізму, геополітики та встановлення нових чітких ліній поділу в регіоні з загостренням вже військово-політичного протистояння. Відбулося те, що ЄС намагався попередити, що свідчить про нагальну потребу для ЄС переглянути свою політику в регіоні, змінити, погоджуючись 3 Д. Тріандафіллу (Triantaphyllou, 2014, с. 289-290), парадигму та підхід Союзу до Чорноморського регіону з урахуванням негативного впливу Росії на трансформаційні програми, які ЄС просуває в регіоні, та власних обмежень $Є С$, взаємної залежності між його роллю всередині об'єднання та поза його межами.

\section{Висновки}

ЄС одним з перших звернув увагу на Чорноморський регіон як на зону, що має потенціал стати або джерелом загроз, або бар'єром для загроз з Близького Сходу та Азії. Намагаючись попередити розвиток першого варіанту, Свропейський Союз бере на себе роль промоутера дружньої атмосфери, економічних та політичних реформ, подолання протиріч, що розділяють країни регіону. Крім того, СС намагався сприяти зменшенню економічного розриву між розширеним $С С$ та його сусідами по Чорному морю. Завдання, яке ЄС ставив перед собою, було значущим. Це можна пояснити економічними інтересами, безпековими міркуваннями, певним моральним обов'язком Свропи перед країнами регіону.

Однак СС помилився щодо готовності країн регіону відкласти протиріччя й амбіції та об'єднати зусилля для розвитку регіону. Іншим 
прорахунком були й завищені очікування щодо позитивного впливу європейських ініціатив на процеси реформування політичної, економічної та законодавчої систем країн регіону.

Втім, найсерйознішою проблемою для $Є С$ стала неузгодженість позицій усередині самого Союзу щодо важливості регіону, інтересів та потенційних загроз для Європи. Це призвело до появи значної кількості документів, заяв та декларацій, що не містили чіткої та зрозумілої концепції політики СС щодо ЧР. Крім того, більшість документів приймають як реакція на ті чи інші події, або дії інших гравців в регіоні. А рішення $є$ компромісом між конфліктом національних інтересів, задекларованою відповідальністю ЄС перед країнами-сусідами та намаганнями відігравати роль глобального актора. Ці протиріччя зрештою обмежили потенціал «сили, що трансформує» й «нормативної сили» Євросоюзу та його інструментів, знизили реальні стимули як усередині Союзу, так i для регіональних партнерів.

Сценарій 1. Сьогодні ситуація стала ще складнішою через встановлення жорсткого контролю Росії в регіоні, яка і раніше негативно сприймала регіональну активність ЄС. Отже, стратегічна важливість регіону для $\mathrm{CC}$ зростає. Попередні результати політики $\mathrm{CC}$ варто враховувати, щоб перейти від інклюзивної та взаємодоповнюючої політики до стратегічного підходу, заснованого на чіткій градації цілей $Є С$ в регіоні, єдності європейських держав, реальному розумінні ризиків та загроз для безпеки усієї Свропи, розробки ефективних методів реалізації своїх рішень.

Сценарій 2. Подальша неузгодженість та дисфункція політики Свросоюзу щодо Чорноморського регіону становить загрозу перетворення ЄС на другорядного гравця в регіоні, який втратить важелі впливу на регіональні процеси та буде вимушений діяти лише в межах гуманітарних проектів. Найбільшою загрозою є посилення вразливості позицій ЄС у безпековій площині. Це добре розуміють в Румунії та Польщі, однак їх зусилля потребують підтримки з боку найвпливовіших держав-членів EC.

\section{Список посилань}

1. Борьба за мир во всем море. О чем поспорили в Стамбуле черноморские державы и кто их примирял. (2017, Май 22). Комлерсант.RU. Взято 3 https://www.kommersant.ru/doc/3304665

2. Веремій, I., Паламарчук, М. (Ред.) (2020). Російська політика в Чорноморському регіоні: загрози й виклики для України. Київ: НІСД.

3. Віце-прем'єр України покладає на Росію відповідальність за кризу в ОЧЕС. (2017, Травень 22). Interfax Ukraine. Взято 3 https://ua.interfax.com. ua/news/general/423060.html 
4. Глазова, А. (2012, Июнь 11). Черноморский регион: Зона особых ин-

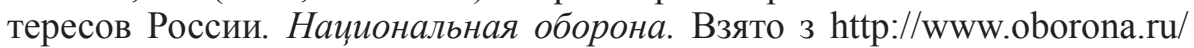
includes/periodics/geopolitics/2012/1106/13439485/detail.shtml

5. Гончар, М., Мартынюк, В., \& Ковалева, А. (2020, Август 11). Шанс на пробуждение после летаргии. Зеркало недели. Взято з https://zn.ua/ international/shans-na-probuzhdenie-posle-letarhii.html

6. Заквасин, А., \& Комарова, Е. (2020, Май 14). «Защита юга России и пресечение провокаций»: как проходит перевооружение Черноморского флота. $R T$. Взято з https://ru.rt.com/fzqj

7. Ившина, О. (2020, Июнь 5). Остановить «сирийский экспресс» России. Почему аналитики предлагают НАТО усилить посты в Черном море. BBC. Взято 3 https://www.bbc.com/russian/features-52938079

8. Кіфу, Ю. (2011). Місце і роль України в чорноморському регіоні: позиції фахівців. Наиіональна безпека і оборона. 4-5 (122-123), 42-43.

9. Тріандафіллу, Д. (2011). Місце і роль України в чорноморському регіоні: позиції фахівців. Національна безпека і оборона, 4-5 (122-123), 48-50.

10. Acikmese, S. A., \& Triantaphyllou, D. (2014). The Black Sea Region: The Neighbourhood too Close to, yet still Far from the European Union. Journal of Balkan and Near Eastern Studies, 16:3, 279-285,

11. Angelescu, I. (2011). New Eastern Perspectives? A Critical Analysis of Romania's Relations with Moldova, Ukraine and the Black Sea Region. Perspectives, 19, 2, 123-142.

12. Asmus, R. D., \& Jackson, B. P. (2004, June 1). The Black Sea and the Frontiers of Freedom. Hoover Institution. Retrieved from https://www.hoover.org/ research/black-sea-and-frontiers-freedom

13. Black sea countries complete preparations for implementation of Black Sea Ring project. (2016, August 23). World Highways. Retrieved from https:// www.worldhighways.com/wh10/wh8/feature/black-sea-countries-complete-preparations-implementation-black-sea-ring-project

14. Black Sea Synergy: review of a regional cooperation initiative - period 20152018. (SWD (2019) 100 final). (2019). Brussels: European External Action Service. Retrieved from https://eeas.europa.eu/sites/eeas/files/swd_2019_100_ f1_joint_staff_working_paper_en_v3_p1_1013788-1.pdf

15. Celac, S., Dibenedetto, A. G., \& Purcăruş, A. (2019). Militarization of the Black Sea and Eastern Mediterranean theatres A new challenge to NATO. Policy Paper. Retrieved from https://www.cesi-italia.org/contents/Analisi/ Militarization\%20of\%20the\%20Black\%20Sea.pdf

16. Coppieters, B. (2002). An EU Special Representative to a New Periphery. The South Caucasus: a Challenge for EU. Chaillot Papers, 65, 159-170.

17. Council Conclusions on the EU's engagement to the Black Sea regional cooperation. (2019, 17 June). Brussels: Council of the European Union. Retrieved from https://www.consilium.europa.eu/media/39779/st10219-en19.pdf

18. Laeken Declaration on the Future of the European Union. (2002). In From Nice to Laeken. European Defence: Core Documents. Chaillot Papers, 51, II, 112-119.

19. Los Fayos de, F. G. (2013). The EU's Black Sea policy: Where do we stand? Policy Briefing. European Parliament. Policy Department. Retrieved from https:// 
www.europarl.europa.eu/RegData/etudes/briefing_note/join/2013/491519/ EXPO-AFET_SP(2013)491519_EN.pdf

20. MEPs speak out in favour of more regional cooperation in the Black Sea region and the South Caucasus. (2008). European Parliament Press release. Retrieved from http://www.europarl.europa.eu/sides/getDoc.do?type=IM-PRESS\&reference $=20080115$ IPR $18588 \&$ format $=$ XML \&language $=E N$

21. Mureșan, L., \& Georgescu, A. (2017, September - December). A Romanian Perspective on the Three Seas Initiative. The Market for Ideas. Retrieved from http://www.themarketforideas.com/a-romanian-perspective-on-the-threeseas-initiative-a314/

22. Preventing Romania's isolation. (2016, August 9). CEPA's Online Journal. Retrieved from: http://cepa.org/europes-edge/preventing-romanias-isolation

23. Priorities of the Romanian Chairmanship-in-Office. (2020, January 1 - December 31). BSEC. Retrieved from http://www.bsec-organization.org/chairmanship

24. Report on the strategic military situation in the Black Sea Basin following the illegal annexation of Crimea by Russia. 2015/2036 (INI). (2015). Brussels: European Parliament Committee on Foreign Affairs. Retrieved from https:// www.europarl.europa.eu/doceo/document/A-8-2015-0171_EN.pdf

25. Schockenhoff, A. (2007). The Need for an EU Black Sea Policy. Working Paper. Retrieved from http://www.fondapol.org/wp-content/uploads/pdf/documents/DT_Mer_noire_ENG.pdf

26. The Black Sea - Confrontation or Cooperation? (2017, May 12-14). Varna Forum 2.0. Thinking Together. Bulgaria, Varna. Retrieved from https://library. fes.de/pdf-files/bueros/sofia/13825.pdf

27. The Black Sea Ring Highway will pass through the territory of Ukraine, Moldova and Romania. (2014, April 18). Ukrinform. Retrieved from https://www. ukrinform.net/rubric-economy/1650817-ukraine_moldova_romania_finalize_black_sea_ring_highway_route_320427.html

28. Tocci, N. (2011). The EU in Conflict Resolution. In Wolff, S., \& Yakinthou, C. (Eds.). Conflict Resolution: Theories and Practice. London and New York: Routledge.

29. Triantaphyllou, D. (2014). The European Union and the Black Sea Region in Search of a Narrative or a New Paradigm. Journal of Balkan and Near Eastern Studies, 16, 3, 286-299.

30. Tsantoulis, Y. (2009). Geopolitics, (sub)regionalism, discourse and a troubled "power triangle" in the Black Sea. Southeast European and Black Sea Studies, 9(3), 243-258.

31. Weaver, C., \& Henderson, K. (Eds.). (2010). The Black Sea Region and EU Policy: The Challenge of Divergent Agendas. Ashgate Publishing, Ltd. 


\section{РОЗДІЛ 6 \\ НАТО У ЧОРНОМОРСЬКОМУ РЕГІОНI: ТРАНСФОРМАЦІЯ ПІДХОДІВ ТА ЦІЛЬОВА ПРИСУТНІСТЬ}

(Шелест Г. В.)

\section{Bcmyn}

2014 рік значно змінив підхід Організації Північноатлантичного договору (НАТО) до Чорноморського регіону. Незважаючи на те, що все ще відсутнє всеосяжне бачення та стратегічне формулювання, Альянс та його окремі члени почали відрізняти регіон та політику НАТО щодо нього від загального набору політик партнерства. Однак, одним з основних питань, на яке НАТО ще повинен дати відповідь, залишається, чи $є$ Чорноморський регіон регіоном його відповідальності чи лише прикордонним (сусіднім) регіоном?

Як би парадоксально це не звучало, але НАТО отримало другий шанс у Чорноморському регіоні після незаконної анексії Криму з боку Pociï. У 2014 р. це не сприймалось як шанс для розширення, а як час для трансформації політики й підходів до відносин з партнерами та власних операційних практик. Ситуація 2014 р., коли спостерігалося нерозуміння загроз та викликів у Чорноморському регіоні з боку офіційних осіб, НАТО посприяла фактичному домінуванню Туреччини на Чорному морі та іï бажанню мати статус регіонального лідера. Наявність трьох держав-членів у Чорноморському регіоні не транслювалась у присутність НАТО в регіоні. Здебільшого Альянсу доводилося покладатися виключно на Туреччину, делегуючи відповідальність у сфері безпеки, оскільки жодної загрози на той момент не передбачалось (Shelest, 2016, с. 198).

На сьогодні, навіть з урахуванням перетворень, які відбуваються, НАТО здебільшого має двосторонній підхід відносно країн регіону,тоді як потрібним є регіональне стратегічне бачення. Східний фланг НАТО в Чорноморському регіоні є фрагментованим простором безпеки, який потребує спеціально скроєного підходу (Vorotnyuk, 2020, с. 23). Наступальні дії Москви будуть мати серйозні наслідки для майбутнього НАТО, оскільки випробовують політичну єдність Альянсу, лідерство США, розгортання сил, дієвість місій, інституційну волю та військові спроможності (Bugajski, \& Doran, 2016, July).

Події 2014 р. та поточна криза порушили питання про те, що насправді означає партнерство НАТО, чи може воно гарантувати безпеку країні, яка не є їі членом? Чи повинно НАТО повернутися до Європи й 
чи є Чорноморській регіон частиною Європи з точки зору НАТО? Грузія разом з Україною стикнулися з найбільшим опором Росії щодо їх прагнень членства в НАТО. Деякі грузинські політики вважали, що російсько-грузинська війна 2008 р. була покаранням та попередженням щодо подальшої євроатлантичної інтеграції Грузії (Ondrejcsak, 2012). Втім сьогодні Грузія та Україна вважають членство в організації єдиним шансом гарантувати власну безпеку.

У цій статті ми не будемо розглядати комплексне питання відносин РФ та НАТО, яке заслуговує окремого аналізу, а розглянемо його в контексті відносин у Чорноморському регіоні.

\section{теоретичний підxіठ}

Роль НАТО та його діяльність у Чорноморському регіоні важко теоретизувати через постійні зміни та різноманітні підходи. Однак нам здається можливим розглядати останні шість років діяльності через призму реалізму й концепти відносин між зусиллями конструктивізму, оскільки створюється нове бачення регіональної політики.

3 точки зору політичного реалізму, роль НАТО в Чорноморському регіоні повинна розглядатися здебільшого в рамках конфронтації двох потужних акторів та концепції балансу сил, оскільки, зазвичай, ситуація спрощується до відносин Росія vs. НАТО. Втім, такий підхід може застосовуватися тільки до найгарячіших періодів «холодної війни». Однією з причин є те, що обидві протидіючі сторони повинні сприймати одна одну в такому статусі. Проте, якщо Російська Федерація продовжує сприймати НАТО та його розширення як загрозу, то Організація Північноатлантичного договору діяла щодо Росії до 2014 р. як до партнера, залучаючи різноманітні формати співпраці.

Розпад Радянського Союзу створив складну конфігурацію в Чорноморському регіоні. Однак, пошук стратегії співробітництва замість конфронтації виявився довгим та невиразним. Більше того, з таким підходом до формату балансу сил було б складно чітко визначити сторони суперництва. Причиною $є$ те, що Туреччина, з одного боку, вбачалась представником НАТО в Чорноморському регіоні, а з іншого, після закінчення «холодної війни» мала власну гру з Росією та, де-факто, була третім гравцем у регіоні.

Турецькі застереження щодо американських довготермінових цілей у Чорноморському регіоні стали зрозумілими, коли з'явилися непорозуміння в перші місяці 2006 р. через пропозицію розширити діяльність Операції НАТО «Активні зусилля» на Чорному морі. Туреччина та Росія заперечили цю ідею, хоча і з різних причин: Москва не хотіла бачити розширення впливу США в Чорноморському регіоні (Aydin, 2009), 
тоді як Туреччина офіційно висловила занепокоєння щодо збереження правового режиму Турецьких проток. Така позиція йшла в розріз з бажанням Румунії та Болгарії, двох нових членів НАТО, щодо більшого натівського та американського залучення до регіональних справ.

3 теоретичної точки зору, цей приклад демонструє, що національні інтереси держав переважали колективні інтереси та багатосторонні підходи для спільного блага. Як Анкара, так і Москва бачили регіон через призму Realpolitik, де отримання більшої влади $є$ основною метою політичної дії. У такій ситуації погляди НАТО, які з середини 1990-х pр. проходили трансформацію від військового до політично-військового союзу, наголошували на питаннях демократії та спільних цінностей, а також колективної оборони, що лише частково збігалося з турецьким поглядом на регіон, в якому НАТО вбачилося корисною складовою багатостороннього механізму лише коли колективна оборона була більш ефективною, ніж національна.

Турецькі офіційні особи, зазвичай, наполягають, що чорноморська безпека повинна бути забезпечена країнами, що мають вихід до Чорного моря. Замість того, щоб збільшувати присутність НАТО, Анкара де-факто заблокувала ініціативу США розширити операцію НАТО «Активні зусилля» на Чорноморський регіон у 2006 р. і запропонувала розширення BLACKSEAFOR та операцію «Чорноморська гармонія», які фактично копіювали «Активні зусилля», що оперували в Середземномор'ї. Росія та Туреччина знайшли ідеальний компроміс, запобігаючи участі інших у регіональних справах. Румунська незгода була фактично проігнорована (Shelest, 2016, с. 198).

Чорноморський регіон наголосив на прерогативі національних інтересів та суперництві за владу навіть у рамках однієї організації. «На тлі турецького блокування присутності НАТО в Чорному морі, Румунія намагається балансувати за рахунок більшої присутності США й становлення стратегічного партнерства, такого як, наприклад, з Польщею» (Krupa, 2018, c. 62). Це суперництво за лідерство в Чорноморському регіоні між Туреччиною та Румунією стало очевидним за останні десять років разом з новими ініціативами, які висувалися обома країнами, що, на їх погляд, мали б гарантувати більше регіональної безпеки. Обидві столиці намагалися представити себе НАТО як найкращого союзника, що може надати Брюсселю та партнерам відповідну інформацію. У результаті це не сприяло накопиченню інформації щодо Росії, але було втрачено момент швидкої відповіді, коли настала справжня загроза.

Російські дії в Чорному морі щодо присутності НАТО спрощено можуть бути пояснені теорією реалізму, оскільки вкладаються у фор- 
мат іiї основної тези - нація може підвищити власні інтереси тільки за рахунок інтересів інших націй; конфлікт або його загроза притаманні системі. Незважаючи на те, що НАТО сприймало відносини з РФ як нове партнерство, найвищий рівень взаємодії без членства - Стратегія національної безпеки Російської Федерації до 2020 р. (прийнята у 2009 р.) зазначає, що «визначальним фактором у відносинах з Організацією Північноатлантичного договору залишиться неприйнятність для Росії планів просування військової інфраструктури альянсу до іiї кордонів і спроби надання йому глобальних функцій, що йдуть врозріз з нормами міжнародного права» (Стратегия национальной безопасности, 2009).

Військова доктрина Росії, прийнята у 2010 р., йде далі. У всьому документі про НАТО зазначено лише двічі: серед інших організацій, 3 якими відносини можуть розвиватися з метою попередження конфліктів, та в частині, що присвячена основним військовим небезпекам (організація не визначена як загроза): «Прагнення наділити силовий потенціал Організації Північноатлантичного договору (НАТО) глобальними функціями, реалізованими для порушення норм міжнародного права, наблизити військову інфраструктуру країн-членів НАТО до кордонів Російської Федерації, зокрема, шляхом розширення блоку» (Военная доктрина, 2010). Ця позиція кристалізувалась у Чорноморському регіоні, зокрема, такими діями, як постійні військово-морські провокації, що відбуваються з 2014 р., й змусили НАТО постати перед ситуацією, яку вони намагалися змінити після 1991 р. - бути залученими до нового силового суперництва та зміни балансу сил.

Проблема полягала в тому, що Росія абсолютно точно знала, чому вона чинить опір, але пропонувала замало бачення того, що вона хоче для регіонального безпекового порядку денного (Antonenko, 2009). Moдернізація Російського Чорноморського Флоту є одним з найбільш амбітних елементів Державної програми озброєння 2011-2020 pр. 18 нових кораблів було замовлено для флоту, а також створено нову інфраструктуру. Метою цієї модернізації є створення об'єднаних сил, спроможних не допустити НАТО до Чорного моря та відтворювати силу поза його межами, загрожувати інтересам США та НАТО в Середземномор’ї та на Близькому Сході (Bugajski, \& Doran, 2016, February).

Саме в Чорному морі Росія вирішила випробувати рішучість НАТО на Східному фланзі шляхом відкритого застосування сили. Порівняння звичайних сил НАТО та Росії демонструє значну асиметрію на користь останньої. У Чорноморському регіоні Росія досягла певних конкурентних переваг (Vorotnyuk, 2020, c. 18). За висновками деяких експертів, Росія в Чорноморському регіоні може сконцентрувати свої сили на не- 
великій території, щоб отримати перевагу, тоді як НАТО має обмежений доступ до цих вод, здебільшого через положення Конвенції Монтрьо 1936 р., яка обмежує військово-морську присутність для неприбережних країн Чорного моря (Bugajski, \& Doran, 2016, February). Таким чином, НАТО виявилося в ситуації постійного пошуку нових методів балансування російській позиції звичайними та незвичайними засобами - через підтримку країн-партнерів та організацію присутності в Чорному морі за принципом ротації кораблів країн-членів НАТО, щоб не порушувати Конвенцію Монтрьо.

3 точки зору конструктивізму, в першу чергу, ми стикаємося з проблемою визначення регіону. Незважаючи на географічні рамки, політичні кордони Чорноморського регіону завжди були предметом дискусій, навіть для прибережних країн, не говорячи про міжнародні організації. Таким чином, коли НАТО визначає свою політику відносно регіону, воно повинно відповісти на питання країни, які ця політика покриває. Відповідь на це питання є важливою, оскільки вона буде мати вплив на подальші кроки в конструюванні реальності існуючих відносин, загроз та викликів, коли одні можуть бути сек'юритизовані, а іншим приділятимуть менше уваги. На сьогодні, виходячи з більшості документів та планів НАТО, ми можемо бачити, що до шести прибережних держав НАТО додає Молдову, Азербайджан та Вірменію. Більше того, НАТО чітко вирізняє Чорноморський регіон від політик щодо Східного флангу (країн Балтії та Східної Свропи), Близького Сходу, Середземномор'я. Це має свої позитивні моменти, оскільки дозволяє чіткіше сформулювати політику. Але це має і негативний ефект, оскільки обмежує бачення всеохоплюючої картинки загроз тоді, коли суперник, такий як РФ, визначає свою морську політику для Чорноморського регіону з проекцією на Середземномор'я, включаючи Близький Схід.

Другою проблемою ідентифікації, яка конструює підходи та дії, була первинна перцепція регіону. Під час «холодної війни» розділений між Варшавським пактом та членом НАТО Туреччиною Чорноморський регіон був буферною зоною без перспективи великої конфронтації з часів Кубинської кризи. Після 1991 р. регіон почали ідентифікувати як регіон співпраці, особливо після створення ОЧЕС. Однак, якщо це було правильно для економічного та соціального співробітництва, то у сфері безпеки регіон ніколи так не визначався. У 2020 р. актори знову визначають регіон як зону конфронтації, обмежуючи розвиток інших політик, окрім спрямованих на відповідь противнику.

Конструктивістська концепція перцепції та місперцепції ідеально ілюструється позиціонуванням за лінією НАТО - РФ у Чорноморсько- 
му регіоні. В умовах конкурентної геостратегічної зони ремілітаризація Чорного моря вбачається Москвою як необхідна політика з метою не допустити стримування Росії та обмеження іiї сили на ії західних кордонах (Bugajski, \& Doran, 2016, February). Сама ідея нелегальної анексії Криму базувалася на страху, що кораблі НАТО можуть з'явитися в гаванях півострова (Direct Line, 2014), навіть тоді, коли Україна мала «позаблоковий» статус, а Альянс не мав жодного інтересу до Чорного моря, особливо щодо розміщення будь-яких кораблів в Україні.

Втім, цей «страх» був достатньо ірраціональним та базувався на російській «ментальній карті» сприйняття НАТО тільки як ворога, а всіх інших такими ж рішучими, як і Москва в боротьбі за «сфери впливу». Таким чином, якщо Кремль сприймав НАТО неправильно, тобто як організацію, яка готується до розміщення своїх сил у Чорному морі, то Брюссель неправильно сприймав Росію як стратегічного партнера, який готовий до більшого залучення. Наприклад, у Стратегічній Концепції НАТО 2010 р. найбільш промовистим параграфом був такий: «Співробітництво НАТО - Росії є стратегічно важливим, оскільки воно робить внесок у створення спільного простору миру, стабільності й безпеки. НАТО не становить загрози для Росії. Навпаки, ми хочемо бачити справжнє стратегічне партнерство між НАТО та Росією, і ми будемо діяти відповідним чином, очікуючи на взаємність від Росії (пар. 33) (Strategic Concept, 2010). Водночас Стратегія національної безпеки РФ до 2020 р. (2009) визначає НАТО так: по-перше, «неспроможність існуючої глобальної та регіональної архітектури, орієнтованої особливо в Євроатлантичному регіоні тільки на Організацію Північноатлантичного договору, а також недосконалість правових інструментів і механізмів все більше створюють загрозу міжнародній безпеці» (ст. 8); по-друге, «визначальним фактором у відносинах з Організацією Північноатлантичного договору залишиться неприйнятність для Росії планів просування військової інфраструктури альянсу до їі кордонів і спроби надання йому глобальних функцій, що йдуть врозріз з нормами міжнародного права» (ст. 17). Така ж логіка аргументів прослідковується й в інших документах Альянсу та Російської Федерації.

Логіка доведень та перцепції призвела до прорахунків у діях НАТО в Чорноморському регіоні та побудові відносин з чорноморськими партнерами - Україною та Грузією. Як зазначає М. Воротнюк, «логіка того, що намагання НАТО бути обережною з Росією може попередити велику конфронтацію, має серйозні вади. Асиметрія залучення може заохочувати Кремль та сприяти ще рішучішим діям, які, як наслідок, роблять конфлікт навіть вірогіднішим» (Vorotnyuk, 2020, с. 19). 
Ще одна проблема, яка вплинула на підхід НАТО до Чорноморського регіону в 2014 р., пов'язана 3 тим, що Копенгагенська школа називає сек'юритизацією. Сек'юритизація питань м'якої безпеки у 2000-х pp. (енергетика, трафікінг, міграція, навколишнє середовище) створила помилкові припущення щодо стану безпеки в Чорноморському регіоні, відповідно, НАТО фактично не бачила своєї ролі там та виявляла мало бажання делегувати функцію вирішувача проблем Свропейському Союзу.

\section{Трансформація підходів НАТО до Чорномор'я після 2014 року}

НАТО не має єдиної офіційної стратегії щодо Чорноморського регіону, досі сприймаючи його здебільшого через двосторонні відносини 3 окремими країнами або відносини з країнами-членами. Обговорюючи Партнерство у Стратегічній Концепції 2010, вона розділяє відносини 3 Росією, Середземноморський діалог, Україну, Грузію, Західні Балкани та Близький Схід, але навіть не бачить Чорне море як регіон, який потребує комплексного та регіонального підходу. Ще у 2004 р. Р. Асмус писав, що Чорноморський регіон має вигляд «цивілізаційної чорної діри в західній історичній свідомості» або «бермудського трикутника західних стратегічних досліджень» (Asmus, 2004). Саме тому Захід приділяв йому так мало уваги.

У 2004 р. експерти наполягали, що, «незважаючи на те, що регіональний підхід протягом довгого часу був частиною партнерських програм НАТО, відсутніми є проекти й програми співробітництва, які фокусувалися б тільки на Чорноморському регіоні. Сама концепція такого регіону є новою для НАТО, і політичні та безпекові води цього моря залишаються переважно незвіданими» (Skonieczka, 2004, с. 99). Після 2008 р., Бухарестського саміту НАТО та російсько-грузинської війни, експерти припускали, що для НАТО більше не залишилося місця в Чорноморському регіоні, а ЄС є єдиним, хто спроможний взяти відповідальність за безпеку в регіоні, оскільки «м’яка» безпека та людська безпека стають більш важливими, ніж «жорстка» безпека.

Сам Альянс розглядав регіон переважно в рамках відносин з Росі$є ю$, не беручи до уваги інтереси інших регіональних гравців, зважаючи на відносини НАТО - Росія. Анексія Криму, мілітаризація Чорноморського регіону, загрози безпеки та безпека судноплавства стали тригерами для НАТО, щоб переглянути власну роль у регіоні.

3 кризою в Україні взимку 2014 р., НАТО продемонструвало, що фокусуючись дуже довго на широкому Близькому Сході, шукаючи нові партнерські формати в Африці та Бразилії, воно майже втратило власні околиці. Ця ситуація також порушила питання щодо справжнього зна- 
чення партнерства. Події в Україні засвідчили, що коли НАТО потребувало партнерів, щоб допомогти з мирними операціями у Косово, Афганістані, Іраку. але коли допомоги потребував партнер, який стикався 3 безпековою кризою, НАТО не мало механізмів, а іноді й бажання допомагати.

Протягом достатньо довгого часу концепція партнерства, незважаючи на свою назву, не сприймалась як співпраця рівних. В країнах не членах здебільшого вбачали імпортерів безпеки, а не експортерів. Тільки під час саміту НАТО в Уельсі у вересні 2014 р., Генеральний секретар визнав, що «один з найбільших контрибуторів сил до місії НАТО в Афганістані ISAF серед країн не членів HATO, Грузія продемонструвала, що є експортером безпеки» (Rasmussen, 2014). Але про Чорноморський регіон ще не згадувалося.

Конфлікт «у» та «навколо» України продемонстрував, що НАТО було неспроможне виконати одне зі своїх ключових завдань, як заначено в Стратегічній Концепції 2010 р.: «Кризовий менеджмент НАТО має унікальний і повноцінний набір політичних і військових спроможностей для надання відповіді повному кризовому спектру - перед, протягом і після конфліктів. НАТО активно залучатиме відповідний набір політичних і військових інструментів для надання допомоги у врегулюванні криз, що розвиваються й можуть потенційно вплинути на безпеку Альянсу, до їх ескалації в конфлікти; для припинення існуючих конфліктів, якщо вони впливають на безпеку Альянсу» (Strategic Concept, 2010). Проте більшість вжитих заходів у відповідь на поновлення напруженості з Росією фокусувалися на безпеці власних кордонів НАТО. Альянс розумів, що НАТО не буде в безпеці, якщо його околиці будуть переживати сум'яття (Krupa, 2018, с. 64). Але, все ще залишалось питання, чи бачить НАТО Чорне море як кордон з Росією, оскільки більшість заходів було реалізовано в країнах Балтії та Польщі.

Вже у 2014 р. партнерство отримало більш значний вимір допомоги. У 2014 р. Грузія отримала Істотний пакет «НАТО - Грузія», як частину Ініціативи НАТО щодо розвитку оборонних та безпекових можливостей і долучилася до Ініціативи взаємної сумісності партнерів, яка дозволяє країнам - не-членам НАТО зробити свій внесок у місії та навчання Альянсу (Wales Summit Declaration, 2014). Україна, на додаток до нових трастових фондів, також отримала у 2016 р. Комплексний пакет допомоги, спрямований на трансформацію збройних сил, побудову спроможностей, боротьбу з гібридними загрозами. Важливим є те, що у відповідь на атаку РФ проти кораблів ВМС України у Керченській протоці у листопаді 2018 р., міністри закордонних справ НАТО у квітні 2019 р. до- 
мовилися про пакет заходів, які дозволять покращити обізнаність НАТО про ситуацію в Чорноморському регіоні та посилити підтримку партнерів Грузії й України - так званий «Чорноморський пакет» (NATO Foreign Ministers, 2019). Цей пакет, у першу чергу, передбачався для України, i надавав допомогу у спостереженні, військовій присутності, а також підтримку українським BMC та береговій охороні (NATO package, 2019). У листопаді 2019 р. НАТО оцінило виконання пакету заходів щодо чорноморської безпеки. Як зазначив Генеральний секретар Й. Столтенберг, «це включає тренування військово-морських сил та берегової охорони. Візити до портів та проведення навчань. Обмін інформацією. Нещодавні візити Північноатлантичної ради до Грузії та України були хорошою нагодою, щоб бачити цей пакет заходів у дії. Постійні військово-морські групи НАТО проводили навчання разом із кораблями Грузії та України, підвищуючи здатність працювати разом» (NATO reviews, 2019). Важливість Чорноморського пакету полягає не тільки в чіткому визначенні Чорного моря як простору діяльності НАТО, але й у просуванні підходу «працювати разом» 3 партнерами, а не просто надавати їм односторонню допомогу.

Варто проаналізувати еволюцію «юридичної» основи визначення ролі НАТО в Чорному морі та перцепції регіону. Це можна зробити, розглянувши декларації самітів НАТО та Стратегічну Концепцію 2010 р., оскільки нова ще перебуває в розробці, а процес рефлексії НАТО може закінчитися лише наприкінці 2020 р.

Стратегічна Концепція 2010 р. не має жодного посилання на Чорноморський регіон. Однак там міститься значна кількість посилань на співробітництво з Росією і поверхневе згадування України та Грузії як партнерів. Це відбулося, оскільки Туреччина вагалась бути «якорем» НАТО в регіоні, блокуючи пропозиції США щодо Чорноморської стратегії, яка розглядалась на саміті НАТО у Стамбулі у 2004 р. Замість цього вона обрала варіант розділити свої зобов'язання союзника НАТО та свої інтереси в Чорноморському регіоні, який вона все ще розглядала як предмет історичної спадщини та національної ідентичності (Antonenko, 2009). Таким чином, лише у 2014 р. можна спостерігати значний зсув у документальному вираженні інтересу НАТО до Чорного моря.

Декларація саміту в Уельсі 2014 р. звертається до Чорного моря один раз у контексті порушення Росією міжнародного права проти Грузії, Молдови, Статуту ООН, Гельсінського заключного акту та ін.: «Крім того, ці події потенційно можуть мати довгострокові наслідки для стабільності в регіоні Чорного моря, який залишається важливим компонентом євроатлантичної безпеки. Поточні дії Росії суперечать прин- 
ципам, на яких було побудовано механізми зміцнення довіри в регіоні Чорного моря. Ми й надалі підтримуватимемо регіональні зусилля держав Чорноморського басейну, спрямовані на гарантування безпеки i стабільності (Wales Summit Declaration, 2014). Ця заява чітко визначає за прибережними державами основну відповідальність за Чорноморський регіон, тоді як НАТО, незважаючи на те, що три прибережні держави є їі членами, не визначає себе частиною регіону.

У Заяві за результатами саміту у Варшаві 2016 р. приділяється більше уваги саме Чорному морю. Статті 10, 17 та 23 посилаються на нарощування Росією своєї військової сили в Криму та на Чорному морі, що не тільки порушує міжнародні норми, але й загострює ситуацію в Балтійському та Чорному морях. Якщо порівняти Заяву з Декларацією 2014 р., то держави НАТО зробили два кроки вперед щодо регіону. По-перше, вони наголосили на необхідності посилити діалог з Україною та Грузією: «Ми й надалі докладатимемо зусиль для подолання наслідків, які створюють для НАТО події в регіоні, і враховуватимемо їх у подальших підходах та політиці Альянсу. Ми підтримуватимемо залежно від обставин регіональні зусилля прибережних держав Чорного моря, спрямовані на зміцнення безпеки й стабільності. 3 цією метою ми поглиблюватимемо також наш діалог з Грузією та Україною» (ст.23) (Warsaw Summit Communique, 2016). Другий важливий крок - визначення нової тактики НАТО щодо регіону, де не тільки прибережні країни, але й організація загалом починає «грати першу скрипку»: «Ми розробимо також шляхи забезпечення цільової передової присутності в південно-східній частині території Альянсу. Належні заходи, спеціально розроблені для Чорноморського регіону, в тому числі ініціатива Румунії щодо створення багатонаціональної рамкової бригади, ...допоможуть посилити потенціал Альянсу щодо стримування й оборони, підвищити ситуаційну обізнаність і засвідчити намір НАТО діяти безперешкодно в мирний час. Це буде потужним сигналом підтримки регіональної безпеки (ст.41) (Warsaw Summit Communique, 2016). Такі кроки можуть бути пояснені тим, що НАТО було в більш прийнятній для себе ситуації порівняно з 2014 р., коли реальні військові загрози, проекція сили та діяльність, спрямована на захист Альянсу, вийшли на перше місце перед політичним суперництвом з Росією.

У Декларації Брюссельського саміту 2018 р. наголошується, що «Вживання низки заходів у військово-повітряній та військово-морській сфері в чорноморському регіоні призвело до істотного посилення присутності й морської діяльності НАТО в Чорному морі» (ст. 26), і детально описуються нові заходи, які було вжито, та сили, які було розміщено. 
Більше того, Чорноморська безпека з'являється в розділах щодо збільшення співробітництва з Україною та Грузією, де наголошують на спільних зусиллях Альянсу та партнерів щодо протидії гібридним загрозам та підвищенні регіональної безпеки.

Водночас, Декларація саміту в Лондоні, прийнята в грудні 2019 р., та Заява з нагоди 70-ї річниці НАТО, прийнята у Вашингтоні у квітні 2019 р., не містять інформації про Чорноморський регіон, таким чином фокусуючись виключно на внутрішньому вимірі адаптації НАТО.

Зміни, які було спровоковано нелегальною анексією Криму в 2014 р., підвищили обізнаність серед європейських країн, які вірили, що ЄC повинен мати безпекову відповідь та переглянути свою зовнішню та безпекову політику, яка повинна бути відображена в Стратегії європейської безпеки, Стратегії європейської морської безпеки та Стратегії СС для Чорного моря (Motion for a European Parliament, 2015). Водночас у межах НАТО такої реакції не було помітно, оскільки там розглядали ризики Чорноморського регіону в ширшому контексті європейської безпеки, наголошуючи на посиленні безпеки в країнах Балтії та на Східному фланзі, а море залишаючи для ініціатив окремих країн.

НАТО знадобилось ще два роки складних переговорів для підкріплення безпеки Східного флангу шляхом розміщення сил як частини посиленої передової присутності, що розглядається як прикриття в разі гібридної або звичайної атаки з боку Росії (Krupa, 2018, с. 56). На Варшавському саміті 2016 р. союзники вирішили розробити «Цільову передову присутність» у Чорноморському регіоні. Таким чином, посилена стратегія НАТО в регіоні сконцентрувалась на повітряно-патрульній місії в Румунії та Болгарії, багатонаціональній бригаді у Крайові (Румунія) та на морській компоненті, ротаційній присутності кораблів країн-союзників у Чорному морі. Спільні сили НАТО високого ступеня готовності (NATO's Very High Readiness Joint Task Force), Сили реагування НАTO, додаткові сили високої готовності союзників, та війська НАТО другого ешелону, в разі необхідності, підсилять передову присутність. Цільові заходи включають більше багатонаціональних навчань на суші, об'єднані спільні посилені тренування, більше морської діяльності та посилену координацію з метою збільшення присутності НАТО в трьох вимірах (Boosting NATO’s Presence, 2019). Затвердження Посиленої передової присутності у країнах Балтії та Польщі, разом з Цільовою передовою присутністю в Чорному морі є найзначнішими рішеннями, прийнятими Альянсом після закінчення «холодної війни» (Krupa, 2018, с. 67).

Румунія була наполегливим адвокатом посилення військової присутності НАТО, що, як не парадоксально, більше збігалося з позицією 
Грузії та України, які були насторожі через РФ, ніж з позиціями Болгарії та Туреччини (Vorotnyuk, 2020, с. 21). Експерти наголошують, що Румунія працювала з НАТО з метою створення спроможностей для швидкого розгортання в Чорному морі, які були б схожими на те, що НАТО вже планувало в Балтійському регіоні та Польщі (Coalson, 2016).

Концепція стійкості стала новим підходом щодо Чорноморського регіону. Метою є підтримка стійкості партнерів, яким загрожує найбільша небезпека на околицях НАТО, з урахуванням потреб кожного партнера та розумінням різниці між ними (Krupa, 2018, с. 64). Чорноморський регіон став випробувальним майданчиком для застосування та розробки цієї концепції. Рекомендації й підходи, які були прийняті на Варшавському саміті HATO у 2016 р. (Warsaw Summit Communiques, 2016), стали ключовими орієнтирами для майбутнього співробітництва.

У 2018 р. у Брюсельській декларації країни-члени підтвердили, що вони будуть «продовжувати зміцнювати роль НАТО у зв'язку з цим, допомагаючи партнерам, на їхнє прохання, у створенні більш сильних оборонних інституцій, поліпшенні належного управління, підвищенні їх стійкості, забезпеченні своєї безпеки і більш дієвій участі в боротьбі 3 тероризмом. Такий внесок у безпеку партнерів сприяє зміцненню нашої безпеки» (ст. 50), а також, що вони «будуть підтримувати зусилля України щодо підвищення стійкості перед гібридними загрозами, зокрема, за рахунок активізації діяльності під егідою платформи НАТО - Україна у протидії гібридній війні» (ст. 66). 3 метою досягнення цих завдань союзники сфокусувалися на сферах підвищеного ризику та взаємодіють 3 партнерами в Чорноморському регіоні з урахуванням усього спектру інструментів співробітництва. Це включає регулярні консультації щодо стратегічної оцінки безпекової ситуації в Чорноморському регіоні, планування відповідних навчань, прискорення практичної допомоги Грузії, Молдові та Україні (Anastasov, 2018).

У 2018-2019 рр. мала місце низка зустрічей за закритими дверима 3 метою обговорення модальностей стійкості в Чорноморському регіоні, які базуються на семи базових принципах НАТО щодо стійкості (Roepke, 2019). У січні 2020 р. Україна та НАТО узгодили порядок спільних навчань в Одесі з захисту критичної інфраструктури в Чорноморському регіоні - «Непорушна стійкість - 2020», призначених на жовтень 2020 р. (Ukraine and NATO, 2020). Метою учасників з України та країн-членів НАТО є спільна розробка алгоритму дій під час кризових ситуацій, які можуть виникнути в Чорноморському регіоні, надання скоординованої, вчасної та компетентної відповіді на кібератаки, захоплення транспортних шляхів та інші загрози. 
Кримська криза 2014 р. порушила питання необхідності перегляду концепції партнерства НАТО. Неспроможність або відсутність волі використовувати наявні рамки для забезпечення територіальної цілісності та безпеки України порушили питання щодо реальної віддачі від партнерства. Якщо під час Євромайдану (листопад 2013 - лютий 2014 р.) для НАТО не було місця в Україні, то кримські події та подальша дестабілізація ситуації в Україні змістила ризики з питань м'якої безпеки у сферу жорсткої безпеки (Shelest, 2015, с. 280). Шість років потому є очевидною більша роль НАТО в Чорному морі та готовність Організації переосмислити власну політику партнерства. Унікальні спроможності окремих країн, як членів НАТО, так і аспірантів, повинні доповнювати одна одну. Тільки шляхом спільних зусиль можливо розробити єдину стратегію щодо регіону (Pkhaladze, 2020, с. 65).

\section{Висновки та сценарії подальщого розвитку}

НАТО потребує як чіткого формулювання власної чорноморської стратегії, визначення наявних та потенційних ризиків і загроз, так і більшого застосування свого потенціалу щодо управління кризами. Кримська криза 2014 р. стимулювала відносини між НАТО та іншими країнами регіону, однак багато часу зайняло визначення їхніх параметрів. Тільки у 2018 р. зміни в баченні Чорноморського регіону з боку НАТО стали явними. Посилене партнерство, побудова стійкості, більше залучення до регіональних справ можуть бути названі трьома головними елементами.

Аналіз декларацій самітів НАТО демонструє еволюцію підходів, більшу увагу до регіону, однак, це є все ще початковою стадією визначення власної ролі. Відсутність чіткої короткотермінової перспективи членства для України та Грузії також додає невизначеності загальній ситуації.

Чорноморська стратегія повинна вийти далеко за межі питань членства, оскільки є основною перешкодою комплексного бачення та обмежує не тільки залучення країн-аспірантів, але й нейтральних країн, таких як Молдова. Сприйняття, що без перспективи членства не може бути активного залучення, є помилковою концепцією, оскільки Чорноморський регіон повинен бачитись як невід'ємна частина НАTO, а не тільки як його «околиці».

Кримська криза надала аргументів на користь більшого залучення НАТО. Туреччина повинна стати менш обережною щодо нових колективних ініціатив, оскільки обидві існуючі ініціативи військово-морського співробітництва було заморожено, а Туреччина самостійно не може гарантувати регіональну безпеку, будучи зайнятою на півдні (Близькому Сході). 
Водночас, між своїми Східним та Південним флангами, НАТО не може визначитися, до якого саме належить Чорномор'я. Доки більшість ініціатив щодо укріплення безпеки на Східному фланзі обмежується діяльністю Румунії, а Південний фланг залишається за Середземномор'ям, Чорне море продовжує перебувати у стратегічному лімбі. Фактично Чорномор'я для НАТО є регіоном, який може об'єднати два фланги, адже більшість викликів $є$ взаємопов'язаними стратегічним загрозами. Якщо обмежувати Чорноморський регіон тільки Східним флангом, це може призвести до домінування російсько-центричного підходу до загроз та перспектив, замість цього повноцінне персональне бачення дозволить розробити комплексний, орієнтований на майбутнє підхід.

Сценарій 1 (за засадами політичного реалізму). Відповідно до цього сценарію, усі задіяні сторони спробують максимізувати власну силу, що призведе до ще більшого суперництва та мілітаризації Чорноморського регіону. Беручи до уваги, що інтереси залучених до процесу сторін $\epsilon$ протилежними, ми будемо спостерігати погіршення безпекової ситуації та активізацію побудови альянсів для підтримки конкуруючих сторін у Чорноморському регіоні. Відповідно до цього сценарію НАТО повинне буде збільшити ротаційну присутність у Чорноморському регіоні, розглянути можливість більшого залучення Грузії та України до операційної діяльності, з можливим наданням ПДЧ. За такого розвитку подій ризики інцидентів у Чорноморському регіоні підвищуються, як і можливість провокацій з боку Росії, яка не тільки спробує збільшити власну силу, але й гарантувати більше географічне покриття. Цей сценарій набуде повної сили в разі, якщо Туреччина припинить свою дуалістичну позицію відносно РФ та НАТО.

Сценарій 2 (за засадами конструктивізму). Відповідно до цього сценарію НАТО необхідно представити своє чітке бачення Чорноморського регіону, мінімізуючи ефект попередніх місперцепцій. Приймаючи різні погляди на регіон, НАТО необхідно мінімізувати сек'юритизацію питань м'якої безпеки, водночас розвиваючи спроможності як країн-членів, так і країн-аспірантів, використовуючи всі можливості Партнерства розширених можливостей, частиною якого $є$ Грузія та Україна. У такому випадку, розробка Чорноморської стратегії НАТО є обов'язковою, тоді як це дозволить чітко визначити загрози, цілі та лінію поведінки Альянсу. Концепція «розумної оборони» може стати новою парадигмою діяльності НАТО в Чорноморському регіоні, що дозволить краще використовувати спроможності та створення ефективної, але не наступальної оборони. Використання принципів «розумної оборони» може призвести до більшого залучення та підвищення спільної безпеки й набуття членства 
(Shelest, 2015, с. 283). Більше того, це може сприяти кращій взаємній сумісності НАТО та партнерів, що є головним завданням угод Альянсу про партнерство.

\section{Список посилань}

1. Военная доктрина Российской Федерации (2010). Official website of the President of the Russian Federation. Retrieved from http://news.kremlin.ru/ ref_notes/461

2. Стратегия национальной безопасности Российской Федерации до 2020 года (2009). Kremlin. Retrieved from http://kremlin.ru/supplement $/ 424$

3. Anastasov, P. (2018, May 25). The Black Sea region: a critical intersection. NATO Review. Retrieved from https://www.nato.int/docu/review/articles/2018/05/25/the-black-sea-region-a-critical-intersection/index.html

4. Antonenko, O. (2009). Towards a comprehensive regional security framework in the Black Sea region after the Russia - Georgia war. Southeast European and Black Sea Studies, 9:3, 259-269.

5. Asmus, R. (2004). Developing a New Euro-Atlantic Strategy for the Black Sea Region: Istanbul Paper \#2. German Marshall Fund. Retrieved from http:// www.gmfus.org/doc/07.28_GMFjstanbul2_Report.pdf

6. Aydin, M. (2009). Geographical Blessing versus Geopolitical Curse: Great Power Security Agendas for the Black Sea Region and a Turkish Alternative. Southeast European and Black Sea Studies, 9:3, 271-285.

7. Bugajski, J. \& Doran, P. (2016, February). Black Sea Rising. Russia's Strategy in Southeast Europe. Black Sea Strategic Report No. 1. Center for European Policy Analysis. Retrieved from http://cepa.org/sites/default/files/Black\%20 Sea\%20Rising.pdf.

8. Bugajski, J. \& Doran P. (2016, July). Black Sea Defended, NATO Responses to Russia's Black Sea Offensive. Strategic Report No. 2, Center for European Policy Analysis. Retrieved from https://www.cepa.org/black-sea-defended

9. Boosting NATO's Presence in the East and Southeast (2019, January 21). NATO. Retrieved from https://www.nato.int/cps/en/natohq/topics_136388. htm

10. Brussels Summit Declaration (2018). NATO. Retrieved from https://www. nato.int/cps/en/natohq/official_texts_156624.htm

11. Coalson, R. (2016, February $\overline{2} 3$ ). News Analysis: Russian Buildup Focuses Concerns around the Black Sea. Radio Free Europe. Retrieved from http:// www.rferl.org/content/russia-black-sea-military-buildup-turkey/27569877. html

12. ComprehensiveAssistance Package(2016). NATO. Retrieved fromhttps://www. nato.int/nato_static_fl2014/assets/pdf/pdf_2016_09/20160920_160920-compreh-ass-package-ukraine-en.pdf

13. Direct Line with Vladimir Putin (2014, April 17). Kremlin. Retrieved from http://en.kremlin.ru/events/president/news/20796

14. Krupa, J. (2018). NATO. In H. Maksak, R. Turcsányi, \& M. Vorotnyuk (Eds.) Understanding Strategic Adaptations: Security Strategies and Policies after 2014, 56-72. Bratislava-Kyiv. 
15. London Summit Declaration (2019). NATO. Retrieved from https://www. nato.int/cps/en/natohq/official_texts_171584.htm

16. Motion for a European Parliament $\bar{R}$ esolution on the strategic military situation in the Black Sea Basin following the illegal annexation of Crimea by Russia, 2015/2036(INI) (2015, May 21). European Parliament. Retrieved from http://www.europarl.europa.eu/sides/getDoc.do?type=REPORT\&reference $=\mathrm{A} 8-2015-0171$ \&language $=\mathrm{EN}$

17. NATO Foreign Ministers agree to enhance security in the Black Sea region (2019, April 4). NATO. Retrieved from https://www.nato.int/cps/en/natohq/ news 165253 .htm

18. NATO package to support Ukraine in Black Sea contains confidential provisions - Klimkin (2019, April 5). UNIAN. Retrieved from https:/www.unian. info/politics/10506531-nato-package-to-support-ukraine-in-black-sea-contains-confidential-provisions-klimkin.html

19. NATO reviews package of measures on Black Sea security (2019, November 21). UKRINFORM. Retrieved from https://www.ukrinform.net/rubric-polytics/2822556-nato-reviews-package-of-measures-on-black-sea-security.html

20. Ondrejcsák, R. (2012). Perspectives of NATO - Georgia Relations. In R. Ondrejcsák \& B. Gorka-Winter (Eds.). NATO’s Future Partnerships, 47-58. Bratislava - Warszawa: CENAA - PISM.

21. Pkhaladze, T. (2020). Georgia and the Black Sea Security: Opportunities for Further Cooperation. UA: Ukraine Analytica, 1 (19), 61-65.

22. Rasmussen, A. F. (2014, September 4). Official Twitter. Retrieved from https:// twitter.com/AndersFoghR

23. Roepke, W-D. \& Thankey, H. (2019). Resilience: the first line of defence. NATO Review. Retrieved from https://www.nato.int/docu/review/articles/2019/02/27/resilience-the-first-line-of-defence/index.html

24. Shelest, H. (2015). Transformation of the NATO Partnership Concept in the Post-Soviet Space: Is Membership the Only Option? In R. Czulda, M. Madej (Eds.). Newcomers No More? Contemporary NATO and the Future of the Enlargement from the Perspective of "Post-Cold War" Members, 275-285. Springer Nature.

25. Shelest, H. (2016). The Change of the Military Balance in the Black Sea Region. In P. Bátor, R. Ondrejcsák (Eds.). PANORAMA of Global Security Environment 2015 - 2016, 193-203. Bratislava: STRATPOL.

26. Skonieczka, J. (2004). The Black Sea Region: A Role for NATO? In R. D. Asmus, K. Dimitrov \& J. Forbrig (Eds.). A New Euro-Atlantic Strategy for the Black Sea Region. German Marshall Fund.

27. Statement on the occasion of NATO's 70th Anniversary (2019). NATO. Retrieved from ato.int/cps/en/natohq/official_texts_165243.htm

28. Strategic Concept for the Defence and Security of the Members of the North Atlantic Treaty Organization (2010). NATO. Retrieved from https://www. nato.int/nato_static_fl2014/assets/pdf/pdf_publications/20120214_strategic-concept-2010-eng.pdf

29. Vorotnyuk, M. (2020). Black Sea Security Deadlocks: NATO - Russia Confrontation. UA: Ukraine Analytica, 1(19), 18-23. 
30. Ukraine and NATO agree on joint exercises in Odesa (2020). Cabinet of Ministers of Ukraine. Retrieved from https://www.kmu.gov.ua/en/news/ spilni-navchannya-ukrayini-i-nato-v-odesi-kuleba-i-kadenbah-pidpisali-dokument

31. Wales Summit Declaration (2014). NATO. Retrieved from https://www.nato. int/cps/en/natohq/official_texts_112964.htm

32. Warsaw Summit Communiqué (2016). NATO. Retrieved from https://www. nato.int/cps/en/natohq/official_texts_133169.htm 


\title{
РОЗДІЛ 7 \\ ОСОБЛИВОСТІ СУЧАСНОГО ПІДХОДУ КИТАЮ ДО КРАЇН ЧОРНОМОРСЬКОГО РЕГІОНУ
}

\author{
(Брусиловська О. І.)
}

Зовнішня політика КНР у сучасній політичній літературі

Науковий дискурс щодо зовнішньої політики КНР характеризується великим розмаїттям думок сучасних науковців, представників як неоліберальної школи, так і неореалістичної.

Традиційна література з Китаю спирається на концепцію «м'якої сили» Дж. Ная - мол. Спочатку під цим поняттям мали на увазі використання нематеріальних ресурсів, культури, переконання та політичні ідеали для впливу на населення зарубіжних країн без застосування силового тиску. Джозеф Най визначив «м'яку силу» як здатність отримувати бажані результати у відносинах з іншими державами за рахунок привабливості власної культури, цінностей та зовнішньої політики, а не примусу або фінансових ресурсів (Nye, 2004); а також як здатність впливати на інші держави з метою реалізації власних цілей через співпрацю в певних сферах, спрямовану на переконання й формування позитивного сприйняття (Nye, 2011). Можна виокремити такі найважливіші інструменти сучасної «м'якої сили»: інформаційні потоки, політичний піар, глобальний маркетинг, мова країни й ступінь її популярності у світі, публічна дипломатія; туризм, спорт і культурні обміни; система освіти та студентські обміни, здатність вести інформаційні війни, міграційна політика (Nye, 2011). Використання «м'якої сили» нерідко помилково ототожнюється з пропагандою. Пропаганда не виключає використання різних варіантів маніпуляції свідомістю людей, але «м'яка сила» цього не допускає.

Марлен Ларуель та Вей (Джош) Луо (Університет Джорджа Вашингтона) критикують теорію «м'якої сили» Джозефа Ная через його «два проблемні припущення: «м'яка сила» накопичується лише країнами 3 ліберальними системами та Сполучені Штати є мірилом для визначення іiі впливу. Припущення, що неліберальні країни не можуть розвинути «м'яку силу», яка б приваблювала аудиторію за кордоном, обмежує нашу здатність усвідомити те, як неліберальна політика й політики набирають обертів. Крім цього, погляд через лінзу, орієнтовану на США, затьмарює нішеві форми м'якої потужності, що проєктують інші країни» (Laruelle, \& Luo, 2020, с. 1). На їх переконання, не слід забувати, що навіть сам Най визнав, що Гітлер, Сталін і Мао володіли «великою 
кількістю «м'якої сили». А сьогодні не можна не визнати вправного користування КНР різноманітними інструментами «притягання».

За словами Даніеле Кармінаті (Університет Гонконгу), як правило, ««м'яку силу» розглядають як таку, що залежить від багатьох суб'єктів поза державою, таких як приватний сектор і громадянське суспільство. Китайські м'які (і жорсткі) зусилля натомість централізовані й перебувають під контролем уряду». Це призводить до обмеження деяких ресурсів, таких як розвиток привабливої масової культури, при одночасному підвищенні інших ресурсів, таких як швидке виділення та використання фінансових та людських ресурсів, як тільки виникає потреба. «Китайські стратегії наголошують на готовності тих, хто приймає рішення, перевірити межі інструментів «притягання» та «спонукання»») (Carminati, 2020, c. 2).

«М'яка сила» Китаю здебільшого покладається на його економічні інструменти. У книзі «Чарівна атака: як «м’яка сила» Китаю перетворює світ» Джошуа Курланцік одним із перших зазначив, що Китай сприймає «м'яку силу» дуже широко. Через міжнародну допомогу КНР розмиває межі між «м'якою» та економічною силою. Джон Вонг зауважив, що Китай вибудовує свою економічну «м'яку силу». Це включає вмілу економічну дипломатію через регіональні торговельні угоди або розширену офіційну допомогу розвитку (ОДР). Девід Шамбо, один з головних сучасних експертів з Китаю, стверджував, що найсильніший інструмент пекінської панелі інструментів - це гроші (Carminati, 2020, с. 1).

Прикладом тісної взаємодії «м'якої» та економічної сили Китаю $\epsilon$ фінансування діаспори 3 метою впливу на неї. Ось чому спостерігачі стверджують, що стратегія КНР «не така й м'яка» (Carminati, 2020, с. 2). Деякі сучасні дослідження визначають поведінку КНР як форму оманливої й маніпулятивної «різкої сили», але методи цих досліджень не завжди переконливі. Можна сказати, що «м'яка сила» КНР «загострюється» за необхідності. При цьому зовнішня взаємодія Китаю націлена перш за все на досягнення економічних дивідендів, і вже потім - ідеологічних та політичних (Carminati, 2020, с. 2).

Найновішим трендом у літературі, що вивчає китайську зовнішню політику, є виявлення причин «ірраціональної поведінки» сучасної стратегії Китаю. Мається на увазі ріст китайської агресивності. Щодо цього Едвард Люттвак висловив думку, що країна вражена «великодержавним аутизмом», викликаним ії̈ стратегічною культурою (віра в центральність та ієрархічну перевагу) та нездатністю обробляти інформацію внутрішніх і зовнішніх подій одночасно. Синдром характеризується «нечутливістю керівництва Китаю до чужої чутливості». Іншими словами, Люттвак 
стверджував, що китайське керівництво стало байдужим до зростаючої опозиції з боку сусідів до його агресивної політики. Крім того, як зазначав Томас Крістенсен, коріння китайської «ірраціональної» поведінки після рецесії крилося у внутрішній динаміці (підйом націоналізму, відсутність бюрократичної координації, плюралізм в ухваленні зовнішньополітичних рішень, недобросовісні угоди) (Palanisami, 2020, с. 1).

А от Аарон Фрідберг стверджував, що напористий характер Китаю не пов'язаний зі стихійним реагуванням, спричиненим внутрішніми чинниками, а є чітко спланованою стратегією, прийнятою після глобальної економічної кризи 2008 р., яка спричинила відносний приріст потужності Китаю. Крім того, він заперечив, що продовження напористості може стати тенденцією на тривалий час. Називаючи поведінку Китаю «раціональною», Фрідберг спростував твердження Люттвака, що Китай «страждає від великодержавного аутизму» (Palanisami, 2020, c. 1).

Приблизно ті ж погляди відображено в праці Рамеза Раджи (Джамія Міллія Ісламія) та Захора Ахмада Дара (Університет Джавахарлала Неру). На їх переконання, жорстка позиція Пекіна щодо Гонконгу в запровадженні закону про національну безпеку відображає його стратегічну поведінку. «Вона є знаком домінуючої сили: будь-яка держава може поводитися агресивно, якщо іiі стратегічні інтереси оскаржуватимуться позасистемним гравцем» (США). Китай укріпився в межах міжнародної політичної структури в результаті бездоганного зростання та розвитку (Raja, \& Dar, 2020, с. 1). Але хоча Китай прагне «піднятися мирно», він зміцнює й свою військову потужність, посилюючи ядерні та звичайні сили для забезпечення своїх стратегічних інтересів. «Якщо США ставатимуть все більш провокаційними, агресивність Пекіна може посилитися» (Raja, \& Dar, 2020, с. 4).

Керівництво КНР звернулося до концепції «м'якої сили» у 2000-х pp. 3 приходом на пост генерального секретаря ЦК КПК Ху Цзіньтао. У партійно-державному апараті й експертному співтоваристві розгорнулася дискусія щодо можливості використання «м'якої сили»в національних інтересах з урахуванням китайської специфіки. У 1993 р. була опублікована стаття професора Ван Хуніна «Культура - «м'яка влада» державної моці», де було представлено нове для Китаю поняття (Callahan, \& Barabantseva, 2017, с. 49). У 2004 р. заступник прем’єра Держради КНР Цянь Цічень оприлюднив статтю, де стверджувалося, що після подій 11 вересня США «потрапили у скрутну ситуацію: недооцінивши роль «м'якої сили» та міжнародних інститутів, вони застосували «жорстку силу», яка засвідчила свою неефективність» (Callahan, \& Barabantseva, 2017, с. 116). Китайські вчені виокремили чотири базові 
складові «м'якої сили» КНР: силу культури, силу політики, силу дипломатії, силу суспільства. У сучасних наукових публікаціях полемічним $\epsilon$ питання, що ж саме має першорядне значення в будівництві національної концепції: «м'яка сила культури» чи «м'яка сила політики». Погляди китайських вчених розділилися, утворивши два самостійних наукових напрями дослідження «м'якої сили» Китаю (Цзайци, 2009, с. 167). На думку Іпіна Ву (Університет Чжецзян Гоншанг), поширений погляд на Китай як незмінний з часів Мао Цзедуна старорежимний авторитаризм не витримує критики. Тільки за 10 років між 2003 та 2013 роками Державна рада Китаю та Національний народний конгрес (NPC) прийняли 336 нових постанов і законів (Wu, 2020, с. 236). Слід звернути увагу й на нещодавній сплеск активного та успішного залучення 3МI, аналітичних центрів, експертів неурядових організацій та інших суб'єктів політики в процес прийняття рішень (Wu, 2020, с. 237). Таким чином, у процесі дослідження зовнішньої політики КНР сьогодні слід враховувати не тільки те, що однопартійна держава виключає суспільних акторів від обмінів владою, але й те, що режим стає толерантнішим та більш чуйним до громадської участі й критики з боку суспільства щодо зовнішньополітичних питань.

Китай та Чорноморський регіон: політико-дипломатичний аспект

Останнім часом 3'явилося не тільки багато цікавих досліджень про зовнішню політику КНР, але й власне новий «бренд» китайської дипломатії, охарактеризований Рагулом Паланісамі (Університет Джавахарлала Неру). На відміну від старшого покоління дипломатів, яке використовувало консервативну й пасивну дипломатію, сучасні так звані «воїни-вовки» стали відомі своєю агресивною та ініціативною тактикою (Palanisami, 2020, с. 1). Вони отримали таку назву за асоціацією з героїчними персонажами популярних у Китаї бойовиків, в яких одинокий «воїн-вовк» рятує світ від глобальної загрози. Китайських дипломатів нового покоління стали називати «дипломатами-вовками». Вони вміло використовують платформи соціальних медіа, такі як Twitter, щоб захищати китайські національні інтереси. Під час пандемії КОВІД-19 ці «дипломати-вовки» використовували соціальні медійні платформи на повну силу, щоб агресивно реагувати на виклики з боку США. Крім того, вони відповідали за поширення дезінформації про походження коронавірусу та західну відповідь на пандемію. За ствердженням С. Корсунського, «безумовно, Китай став діяти агресивніше, адже на кону дві головні цілі, сформульовані нинішнім керівництвом КНР: досягти рівня «помірно квітучої країни» до 2021 р. та зробити Китай «багатою, впливовою, де- 
мократичною, цивілізованою та гармонійною» країною до 2049 р. Ніщо не повинно цьому завадити» (Корсунський, 2020). Таким чином, в цілому за період пандемії спостерігалося посилення активності китайських дипломатів на світовій арені.

Якщо порівнювати китайську агресивність у період глобальної фінансової кризи 2007-2008 pр. 3 дипломатією на піку пандемії коронавірусу, можна помітити, що Китай виявився відносно незайманим порівняно з західними ліберальними демократіями. Це спонукало китайський уряд в обох випадках просувати свою модель управління як найкращу альтернативу західній (Palanisami, 2020, с. 1). Китайська зовнішня політика відійшла від принципів Ден Сяопіна - «триматися в тіні» в міжнародних справах і «не претендувати на лідерство».

Політична система Китаю стала більш централізованою за президента Сі Цзіньпіна, який став генеральним секретарем КПК та президентом Китаю у 2012-2013 pp. Сі поставив за мету «омолодження китайської нації». У листопаді 2012 р. він створив Центральну національну комісію з безпеки (CNSC), що підпадала під керівництво ЦК КПК і звітувала безпосередньо Політбюро.

У 2018 р. Центральна комісія з закордонних справ (CFAC) замінила колишню Провідну малу групу з закордонних справ. Як і CNSC, CFAC також очолюється Сі та іншими ключовими фігурами КПК. 3 часу свого створення CFAC почала функціонувати як ключовий інститут, що координує зовнішню політику Китаю. Вона також ознаменувала ще більшу централізацію ухвалення рішень у зовнішній політиці КНР. Але великим недоліком цієї системи є те, що лояльність компартії при просуванні на керівні посади цінується вище регіонального досвіду кандидатів. Це видно зі складу CFAC, до якої належать особи, котрі не мають знань у сфері зовнішньої політики. Деякі експерти стверджують, що створення CFAC додало нашарування бюрократії до вже неефективного політичного процесу. Однак, на думку Р. Паланісамі, можливі переваги містять чітку й передбачувану зовнішню політику Китаю. Спостерігаючи за змінами, принесеними за роки правління президента $\mathrm{Ci}$, можна впевнено зробити висновок, що сучасна дипломатична агресивність «воїнів-вовків» санкціонується з самого верху. У Китаї, на відміну від демократичних країн, групи інтересів не впливають на політику. Водночас агресивніша дипломатична поведінка служить інструментом відвернення уваги населення від економічних негараздів, спричинених торговельною війною з США, а потім пандемією коронавірусу та протестами у Гонконзі (Palanisami, 2020, c. 2).

Цікавим є вироблення сучасного ритуалу ухвалення рішень у КНР. Так, один раз на рік у м. Бейдахе провінції Хебей, за 300 км від столиці, 
збирається еліта Китаю для проведення непублічних консультацій щодо насущних проблем країни. Керівники Комуністичної партії КНР, їхні радники та помічники, найкращі уми науки, колишні чиновники, чия думка ще важлива, і навіть духовні лідери Тибету впродовж місяця шукають «серединний шлях» («шлях життя») щодо питань зовнішньої та внутрішньої політики. «Серединний шлях» означає ведення переговорів із максимальним терпінням, реалізацію власних планів без озирання на критику, послідовне просування маршрутів мегапроєкту «Один пояс один шлях» і ліній телекомунікації 5G. Зазвичай те, про що домовляються в «літній столиці», пізніше імплементується через рішення партійних органів, парламенту й уряду (Корсунський, 2020).

Якщо структура вироблення зовнішньополітичних рішень з 2012 p. зазнала радикальних змін, то інструменти їхнього втілення залишилися традиційними. Найважливішим дипломатичним інструментом КНР $€$ інтенсифікація двосторонніх відносин. Слід зазначити, що двосторонні відносини для китайської сторони завжди були важливішими за багатосторонні, тому що вони дають більше свободи для маневру та застосування різних стратегій. Китай прагне вирішувати всі проблеми окремо 3 кожною зі сторін або не робити нічого та «продовжувати господарювати на річці так, начебто вона належить йому від витоку до гирла» (Rong, 2018). Ця китайська риса особливо чітко проявлясться у Чорноморському регіоні, тому що він $\epsilon$ менш структурованим та пов'язаним угодами, аніж, наприклад, Балтійський або Північноамериканський.

Враховуючи, що найбільша чорноморська організація - ОЧЕС - ледве животіє, можна взагалі ставити питання про існування регіону в будь-якому сенсі, окрім власне географічного. Для позасистемних (зовнішніх) акторів слабкість зв'язків та низка внутрішньо-регіональних проблем робить особливо великою спокусу грати на їх протиріччях. Тому в ЧР поступово посилювався вплив Китаю, Ірану, країн Перської затоки.

Це викликало значне невдоволення з боку ініціатора створення ОЧЕС - Турецької Республіки. Стратегічна концепція "Stratejik Derinlik" А. Давутоглу (2001) виходила з того, що Туреччина - близькосхідна, балканська, кавказька, середньоазійська, каспійська, середземноморська та чорноморська держава, яка спроможна відігравати стратегічну роль у всіх перерахованих регіонах одночасно i, таким чином, претендувати на глобальну роль. Однак, переоцінка політики протягом 2002-2009 pp. трохи змінила акцент: Туреччина як і раніше розглядалася як «приречена на центральне місце в міжнародних відносинах», але завдання зменшити залежність від Заходу призвело до мети встановити відносини 3 важливими незахідними країнами - від Росії та Ірану до Китаю (Мав- 
ріна, 2012, с. 49-52). У 2010 р. сторони вперше заговорили про можливість встановлення відносин стратегічного партнерства, а в 2015 р. голова КНР Сі Цзіньпін і президент Туреччини Тайїп Реджеп Ердоган домовилися розвивати «стратегічне співробітництво на основі взаємної поваги» («Голова КНР Сi», 2015). I все ж політико-дипломатичні відносини між країнами $є$ значно вразливішими, аніж їх економічна складова. Причина тут не тільки в уйгурському питанні, важливому для Туреччини, а й у тому, що в ЧР сторони поводяться скоріше як суперники, аніж партнери.

Особливим пріоритетом КНР у регіоні є Російська Федерація, яка так само як і Турецька Республіка є одним з наймогутніших гравців у Чорноморському регіоні, а для Китаю - одним з головних сусідів та партнерів. Не дивно, що регіональні відносини підпорядковані глобальним завданням Китаю. У цьому контексті проблеми, пов'язані зі спільним кордоном, на довгі роки визначили порядок денний російсько-китайських відносин. I тільки після того, як 20 травня 2005 р. Державна Дума ратифікувала угоду про демаркацію російсько-китайського кордону, Китай почав розвивати більшу активність у відносинах з РФ (Карпов, 2013). Угода усунула найважливіший фактор розбіжностей, який у перспективі здатен був призвести до загострення відносин (Галенович, 2010 , с. 35). Після цього російсько-китайські відносини офіційно визначаються сторонами як «всеосяжне рівноправне довірче партнерство та стратегічна взаємодія» («Концепция внешней политики», 2019). Основні принципи та напрями двосторонньої взаємодії відображено в Договоpi про добросусідство, дружбу та співробітництво від 16 липня 2001 р. («Договор о добрососедстве», 2001). Президент Росії Володимир Путін і голова КНР Сі Цзіньпін щорічно зустрічаються не менше п’яти разів. Із 1996 р. діє механізм регулярних зустрічей глав урядів Росії і Китаю, щорічно проходять візити глав зовнішньополітичних відомств двох країн, вони також на регулярній основі зустрічаються «на полях» міжнародних заходів, зокрема по лінії ООН, «Групи двадцяти», АТЕС, БРІКС, ШОС. Між МЗС двох країн діє система планових консультацій на рівні заступників міністрів і директорів департаментів. Загалом було укладено понад 300 міжурядових договорів і угод, які охоплюють практично всі сфери співробітництва (Давыдов, 2004). Однак як на світовому, так і на регіональному рівні країни діють відповідно до національних інтересів, а це не завжди сприяє їх співробітництву.

Щодо України, то вона завжди була не пріоритетною для КНР порівняно з Росією. Відносини між нашими країнами розвивалися повільно й не виходили за межі торгівлі та інвестиційних інтересів. Тільки 
у червні 2011 р., під час візиту Голови КНР Ху Цзіньтао, у Києві було підписано «Спільну декларацію про встановлення і розвиток стосунків стратегічного партнерства», а також контракти на суму 3,5 млрд. дол. До кінця 2011 р. товарообіг подолав психологічну позначку в 10 млрд. дол. (Шевырев, 2011). Але реалізація цих та підписаних раніше документів після 2013 р. змінилися на гірше.

Лінія поведінки КНР відносно української кризи 2013-2014 рр. й російсько-української війни 2014-2020 рр. формувалася з урахуванням національних інтересів Китаю, який за своїми ресурсами та численними геоекономічними й геополітичними проектами все більше перетворювався на наддержаву. Позиція Пекіна відображала «принциповий нейтралітет» Китаю у світових конфліктах, відповідала його політичним й економічним інтересам в Свропі та планам з перезавантаження китайсько-американських стосунків.

Перша реакція Китаю на загострення ситуації навколо України була досить стриманою. Він обмежився заявами про невтручання й необхідність мирних, дипломатичних методів вирішення конфлікту. Але невдовзі відповідальність за погіршення політичної ситуації в Україні Китай поклав на зовнішні сили: Пекін звинуватив Захід у маніпулюванні «думками людей» щодо угоди про асоціацію з Свросоюзом. «Втручання Заходу завадило діалогу між урядом і опозицією, посіявши насіння подальших соціальних і політичних розбратів усередині країни», - повідомляло агентство Сіньхуа («Китай недоволен», 2013). Ситуація в Україні вплинула на глобальні й регіональні інтереси КНР, наражала на певні ризики іiі зовнішню політику. 24 лютого 2014 р. офіційний представник МЗС КНР Хуа Чуньїн заявила: «Ми сподіваємося, що політичний процес з вирішення кризи в Україні просуватиметься в межах закону». КНР пропонувала, щоб українська сторона на практиці захищала законні інтереси різних народів України, оскільки в Китаї звернули увагу на «нестримно розпалювані русофобські настрої» («Очередная пресс-конференция», 2014).

Під час голосування в РБ ООН з питання про Крим, від якого Китай утримався, а Росія наклала вето на відповідну резолюцію, українське МЗС зажадало від китайських дипломатів роз'яснень щодо їхньої позиції. Посол в Україні Чжан Сіюнь заявив, що одним з базових постулатів зовнішньої політики Китаю є принцип невтручання. Однак це не могло задовольнити Київ, який шукав міжнародної підтримки щодо визнання кримського референдуму недійсним, а політики Москви агресією. На засіданні Ради Безпеки 16 березня 2014 р. постпред КНР в ООН Лю Цзеї запропонував посередництво КНР у вирішенні проблеми. Він 
запропонував, по-перше, «створити міжнародний координаційний механізм за участі зацікавлених сторін для вироблення політичного врегулювання української кризи», по-друге, закликав усі сторони утриматися від дій, які можуть призвести до подальшої ескалації конфлікту. Лю Цзеї заявив, що голосування за проєктом резолюції, внесеним США, лише «посилить конфронтацію і ще більше ускладнить ситуацію», і нагадав, що «зовнішнє втручання» стало «важливою причиною, яка призвела до насильницьких дій на вулицях українських міст, і викликало кризу в країні» («China makes proposals», 2014). Крім того, офіційні ЗМI КНР виступили з засудженням політики США та їх союзників. 19 березня 2014 р. агентство Сіньхуа поширило коментар про прихильність Заходу до подвійних стандартів і виключно власних інтересів, що проявилося у широкому географічному діапазоні «від Косово до Південної Осетії, а також від Комор до Криму» (Покась, 2017, с. 147).

Щодо протистояння на Донбасі, то 6 березня 2014 р. у розмові 3 помічником президента США з національної безпеки Сьюзан Райс держрадник КНР Ян Цзечі наголошував, що «законні права й інтереси всіх етнічних груп в Україні мають бути враховані при вирішенні української проблеми» («Chinese State Councilor», 2014). Намагання КНР врахувати всі складнощі в іiї стосунках із СС, Росією, Україною та США не могли приховати - при видимій нейтральності - «крен» на користь Росії. Про це ж засвідчив аналіз мас-медіа Китаю. На думку німецького журналу Der Spiegel, «сильні слова про Росію» у провідних китайських 3МI завідчили, що «у протистоянні Росії з Заходом найбільш населена країна у світі стоїть на боці найбільшої країни» (Клусман, 2014). А газета «Хуанцю шибао» зазначала: «Люди, які підтримують Москву, вважають, що дії Росії - реакція на довгостроковий стратегічний тиск з боку Заходу... Ми більш схильні погодитися 3 тими, хто підтримує Росію» (Покась, 2017 , с. 148). Отже, доки не буде вирішено російсько-український конфлікт, про налагодження політичної співпраці Китаю з Україною говорити не доводиться.

I навпаки, та ж сама раціональна та стримана поведінка в Свразії дозволила Китаю проводити позитивну й інклюзивну політику на Кавказі. Китаю вдалося дати зрозуміти, що він готовий говорити з усіма без обмежень. Причому робити це, не викликаючи невдоволення регіональних держав (насамперед Росії), які претендують на вплив у цій зоні (Леонова, 2013, с. 37).

Щодо Вірменії, то у 2015 р. було укладено оборонну угоду, яка містить положення про взаємну військову підтримку. Крім того, Среван офіційно погодився брати участь у китайському проєкті нового «Шов- 
кового шляху» (Роллан, 2018). Цю дружбу ще більше скріпили китайські інвестиції й стратегічні для вірменської економіки рішення. Для Вірменії позитивні двосторонні відносини з Китаєм відіграють важливу роль: ситуація в економіці складна, і такий інвестор, як Пекін, може кардинально змінити розклад. Крім цього, зміцнення дружніх стосунків 3 Пекіном (вони існують і розвиваються з 1996 р.) може допомогти цій кавказькій республіці вирватися з лещат відносин з Росією так, щоб та при цьому не відчути для себе загрози.

Китайська дипломатія налагоджує відносини не тільки з Среваном: за останні роки їй вдалося встановити тісні зв'язки з Азербайджаном. Домогтися цього було не просто: у Баку не забули, як в 2008 р. Пекін відмовився підтримати резолюцію ООН про виведення вірменських сил з окупованих азербайджанських територій. Проте Китай засвідчив, що не рівняється на якийсь із «таборів» у регіоні.

Натомість політико-дипломатичні відносини КНР з Болгарією та Румунією мають негативну динаміку з моменту вступу цих країн до СС у 2007 р. Новачки СС втратили частину свого суверенітету, передавши важливі інструменти зовнішньої політики до Брюсселя. Тепер вони змушені притримуватися принципів загальної зовнішньої політики та політики безпеки СС.

Безпрецедентна пандемія COVID-19 підірвала відносини між $\mathrm{CC}$ та Китаєм. На думку Каріма Салема, «спроби Китаю розділити Свропу у розпал кризи охорони здоров'я, використовуючи відверто ворожу риторику щодо здатності західної демократії ефективно реагувати на надзвичайні ситуації, послужили сильним поштовхом до того, що Європа повинна стати більш наполегливою з Китаєм, коли ставлять під сумнів іiі інтереси та цінності» (Salem, 2020, с. 1).

Важливим фактором у відносинах між КНР та ЄС стало зростання напруженості між США та Китаєм. Обидві сторони посилюють тиск на європейські країни з питань, які вони вважають життєво важливими для їхніх стратегічних інтересів. Це особливо помітно у вирішенні питання щодо ролі китайського телекомунікаційного гіганта Huawei в наданні 5G мереж до європейських країн. США закликають вилучити Huawei 3 європейських мереж 5G. Одночасно й китайський уряд посилив тиск на європейські країни не вилучати китайського оператора з розвитку мобільного Інтернету нового покоління. Пандемія коронавірусу прискорила й посилила напруженість між двома державами. Виникнення вірусу спонукало Вашингтон і Пекін до участі в шаленій грі щодо провини за витоки пандемії. Президент Дональд Трамп назвав COVID-19 «китайським вірусом», тоді як високопоставлені китайські чиновники ствер- 
джували, що США створили вірус і «посадили» його в Китаї взимку 2019 р. Лідер Білого дому пішов далі, вивівши США зі складу Всесвітньої організації охорони здоров'я у відповідь на те, що ВООЗ нібито виступає «за» Китай. Напруженість посилилася ще більше, коли обидві сили наказали закрити свої консульства (Salem, 2020, с. 1).

Це не означає, що Європа буде орієнтуватися на примусову позицію Трампа щодо Китаю. Свропа вважає за краще проводити щодо Китаю політику, яка відповідає їхнім окремим інтересам, з акцентом на співпрацю та партнерство з Китаєм у питаннях зміни клімату, глобального управління та усталеного розвитку, розширення торгівлі сільськогосподарською продукцією, а водночас протистояти поглибленню авторитаризму в Гонконзі та провінції Сіньцзян, посилювати свою стратегічну автономію в сфері охорони здоров'я, технологій та промисловості.

Китай зі свого боку у відносинах з пострадянськими державами Чорномор'я керується насамперед пріоритетом збереження партнерства з Росією, а у відносинах з Болгарією та Румунією - пріоритетом збереження партнерства з СС. Така складна взаємозалежність та підпорядкованість регіональних завдань завданням глобальним значно обмежує сучасну активність КНР у Чорноморському регіоні.

\section{Економіка як інструмент політики КНР у Чорномор'ї}

Беручи до уваги специфіку кожного регіону, Китай робить акцент на інструменти «м'якої сили», найбільш вигідніші для держави. Для реалізації своєї політики КНР використовує основні інструменти економічної, дипломатичної та гуманітарної «м'якої сили». Китай не сприймає військово-політичних союзів, роблячи акцент на торговельно-економічній взаємодії (Callahan, \& Barabantseva, 2012, с. 110). Так, наприклад, за останні 10 років Туреччина та Китай уклали угоди, спрямовані на інтенсифікацію зв'язків у сфері економіки та торгівлі, включаючи Рамкову угоду про розширення торговельно-економічного співробітництва, угоду про спільну реалізацію інфраструктурних проектів у третіх країнах, включаючи Чорноморський регіон, про створення робочої групи за проектом Шовкового шляху, який повинен, зокрема, активізувати торговельні відносини Туреччини й Китаю з державами Кавказу. У квітні 2012 р. Туреччина та Китай уклали дві угоди у сфері ядерної енергетики, угоду щодо участі китайських компаній у створенні високошвидкісної залізниці між Анкарою та Стамбулом, угоду про будівництво атомної електростанції у ТР. Крім того, було оголошено про перехід у двосторонній торгівлі до здійснення розрахунків у національних грошових одиницях. Китай став третьою країною (після Росії та Ірану), з якою Туреччина уклала таку угоду, що засвідчує зростання впливу КНР на ТР (Мавріна, 
2012, с. 64). У 2015 р. голова КНР Сі Цзіньпін висунув три пропозиції, щоб зрушити двосторонні відносини з Туреччиною у «правильному напрямі»: по-перше, застосовувати механізм міжурядової комісії зі співробітництва на рівні заступників глав урядів, щоб координувати взаємодію в різних сферах: політиці, торгівлі, економіці, безпеці та гуманітарній сфері. По-друге, надавати основну увагу співпраці в сферах високошвидкісної залізниці та нових джерел енергії. По-третє, сприяти взаємодії в трьох нових сферах - космонавтиці, фінансах та інвестиціях. За словами Сі Цзіньпіна, китайський уряд буде послідовно заохочувати китайські підприємства вкладати капітал в Туреччину і створювати там бізнес («Голова КНР Сі», 2015).

Економіка $\epsilon$ важливою складовою політики КНР у відносинах 3 РФ, хоча в суто економічному плані взаємодія з США та країнами Заходу, вочевидь, має для КНР вагоміше значення, ніж торгівля та спільні проекти з Росією. Геополітичне становище Росії та Китаю передбачає вирівнювання економічного стану прикордонних регіонів обох країн. Однак розвиток двосторонніх відносин показує очевидну зацікавленість китайської сторони та відсутність відповідних дій та темпів розвитку торговельно-економічного співробітництва з боку Pociï (Barnett, $\&$ Duvall, 2005). На світовому ринку країни перебувають на нерівних позиціях з точки зору стратегічного розвитку: Росія скеровує зусилля на захист власних інтересів з позиції «осадженої фортеці», а Китай - 3 точки зору розвитку присутності в усіх країнах світу та багатосторонньої співпраці (Карпов, 2013).

Нафта $\epsilon$ наріжним каменем у російсько-китайських економічних відносинах. 21 травня 2014 р. російський «Газпром» і Китайська національна нафтогазова корпорація (CNPC) уклали тридцятирічний договір на постачання газу. Контракт передбачає газопостачання до 38 млрд. кубометрів на рік на суму $\$ 400$ млрд. за 30 років і $є$ найбільшим за всю історію газової галузі СРСР і Росії, i, мабуть, найбільшою угодою про постачання газу за всю історію світової газової промисловості («Газпром возобновил», 2020). Китай зазначає продовження зростання експорту енергоносіїв з Росії. У свою чергу, найбільший приріст імпорту з КНР до Росії склала група «електричні машини й устаткування та їх частини». Як повідомляється в доповіді Головного митного управління КНР, експорт Китаю в РФ у 2020 р. скоротився на 14,6 \% (9,151 млрд.дол.).РазомзтимімпортросійськихтоварівуКНРзрісна 17,3\% (16,202 млрд. дол.) («Товарооборот России», 2020).

У відносинах з Україною Китай зацікавлений насамперед у військово-технічному співробітництві, оскільки наша країна має у розпоря- 
дженні напрацювання практично у всьому діапазоні зброї - від авіаносців до міжконтинентальних балістичних ракет. Для КНР, яка у XXI ст. отримала можливість конвертувати зростаючу економічну потужність у потужність військову, можливість придбання низки технологій складно переоцінити. Пекін проявив інтерес до майже 30 напрямів співпраці у військово-технічній сфері, зокрема авіаносців, великих транспортних літаків, надзвукових навчально-тренувальних реактивних літаків, танків, ракет «повітря-повітря» і «повітря-земля». Співпраця з Україною допомогла ввести в дію авіаносець «Ляонін» (він був оснащений українськими газовими турбінами UGT-25000, або ДН/ДА-80), досягти успіху в розробці нових бойових кораблів, танків, літаків, особливо авіадвигунів. Згідно з повідомленням Chinese Defense Review, у 1990-х роках Китай отримав ці турбіни без технологій, але пізніше Україна погодилася передати Китаю й усі технології («20 років», 2014). За даними Стокгольмського міжнародного інституту досліджень проблем світу SIPRI, y 1992-2008 pp. Китай посів друге після Пакистану місце серед імпортерів українських озброєнь з 624 млн. дол. А з 2009 р. Китай для України в цілому став економічним партнером номер один, але, на жаль, ненадовго (Тымчук, 2017). Станом на сьогодні перспективи військово-технічної співпраці України й Китаю не знані. По-перше, головний партнер Китаю, державний концерн «Укроборонпром», з 2014 р. сконцентрував увагу на забезпеченні зростаючих потреб оборони України, що викликало зниження зовнішніх постачань військової техніки (Терещенко, 2014). По-друге, взаємодія України й СС призводить до того, що за правилами ЄС про ембарго на постачання озброєнь і техніки подвійного призначення, Києву доводиться скоротити торгівлю зброєю з КНР. По-третє, за 25 років Китай отримав від України необхідні йому технології, а нові розробки в нашій країні ведуться вкрай повільно через хронічне недофінансування.

Водночас торговельно-економічні зв'язки й інвестиційна діяльність так і не стали пріоритетами Китаю, оскільки український ринок не є достатньо об'ємним, а інвестуванню в економіку перешкоджає бюрократія та високий рівень корупції в Україні. Доля України в загальному обсязі торгівлі Китаю є вкрай незначною і складає всього 0,18 \% («Торговельно-економічне співробітництво», 2020). Міжурядова українсько-китайська комісія не збиралася з жовтня 2013 р. Тривала пауза в політичних стосунках вплинула на економічні показники, в тому числі на двосторонній товарообіг й інвестиції. Спостерігається стрімкий обвал у двосторонній торгівлі порівняно з довоєнними роками, коли товарообіг був понад 10 млрд. дол. 32015 р. товарообіг між Україною і Китаєм не 
перевищував 6 млрд. дол. («Торговельно-економічне співробітництво», 2020).

Розглядаючи економічну «м'яку силу» КНР у трьох кавказьких республіках, слід зазначити, що в економічній співпраці Китай визначив три основні сектори: хімічна промисловість у Вірменії, автомобілебудування в Азербайджані, фінансовий сектор і будівництво в Грузії. Загалом, Китай розглядає Кавказ як місце для здорової конкуренції з іншими зовнішніми силами за збільшення свого впливу (Русакова, 2010, с. 189). 3 іншого боку, Пекін зацікавлений у Південному Кавказі з точки зору створення стійкого економічного плацдарму на підступах до європейських ринків, з якого в перспективі можна здійснювати експансію китайських товарів, інвестицій і робочої сили (Бабаян, 2011, с. 74).

Таким чином, у контексті зміцнення китайських позицій у ЧМР Пекін робить основну ставку на свій найбільш конкурентоспроможний зовнішній ресурс - економічне проникнення з розгортанням потенціалу поступальної експансії на внутрішніх ринках. Запропонувавши ініціативу «Один пояс - один шлях», КНР збільшує свою економічну присутність і розвиває гуманітарні зв'язки. Наприклад, Грузія уклала угоду про вільну торгівлю; Азербайджан зацікавлений у транспортних проєктах через вихід до Каспійського моря; Вірменія стала першою кавказької країною, яка надала перевагу китайським озброєнням над російськими (Роллан, 2018). КНР вкотре продемонструвала свою прагматичність, віддавши перевагу залізничному проєкту в Азербайджані, а не його вірменській альтернативі: перший надає транзитні можливості в обсязі 20 мільйонів тонн на рік, тоді як другий, за висловом Н. Роллана, «все ще залишається фантазією» із закриттям турецько-вірменського кордону в 1993 р. (Роллан, 2018).

Економічний інтерес допомагає швидко забути деякі дипломатичні розбіжності: на початку 2013 р. китайські інвестиції в Азербайджан склали не менше мільярда доларів. Китайці всюди скрупульозно дотримуються логіки невтручання у внутрішні справи держав регіону. В Азербайджані та сусідніх країнах це незмінно сприймається як знак поваги. Слід також зазначити, що інвестиції було зосереджено на азербайджанській нафті, але торкнулися не тільки ії: як і у Вірменії, китайці використовують свої знання в галузі ТЕС. У результаті Китай виступає як країна, налаштована на довгострокові інтереси (Albert, 2018).

Китаю вдалося зміцнити двосторонні зв'язки навіть з Грузією, хоча та і вважається проєвропейською й прозахідною країною. Як це часто буває з КНР, розвиток зв'язків з країнами регіону бере початок з економіки. 3 Грузією Китай розширює відносини насамперед в економічній та 
сільськогосподарській сферах. Можна припустити, що в рамках різних проектів, які мають на меті здійснювати поставку китайських товарів до Європи, Пекін намагатиметься скористатися вигідним геостратегічним розташуванням країни та використовувати ії як один з транспортних коридорів. Саме тому найбільші китайські інвестиції надходять здебільшого до транспортної сфери, не відмовляючи Грузії в інвестуванні енергетичних проєктів. На новий рівень виходять китайсько-вірменські відносини. Зростає кількість китайських інвестицій у республіці, участь китайської сторони в різних енергетичних проектах, у сфері інформаційних технологій, сільського господарства, а також у військовій сфері доводить тенденцію поглиблення двосторонніх взаємин («Китай активизируется», 2019).

У Болгарії та Румунії Китай робить акцент, у першу чергу, на економічних інструментах, які формують інвестиційну та фінансову привабливість держави. Китайці почали активно освоювати ці нові держави ЄС незабаром після власних реформ, які дали свободу підприємництву, і після того, як в країнах-сателітах СРСР відбулися революції, внаслідок яких вони вийшли з-під тривалої кількадесятилітньої «опіки» Москви та відкрилися світовому ринку. Починаючи з 2011 р. інтерес Китаю до країн СС помітно зріс (Шишелина, 2019, с. 7). Болгарію та Румунію КНР розглядає як зручний канал торговельно-інвестиційної експансії на просторі $\mathrm{CC}$, як «полігон» для відпрацювання механізмів подібної експансії й потенційний інструмент створення сприятливого ставлення до китайських ініціатив в інститутах ЄС. За останнє десятиліття торгівля товарами та послугами КНР - СС зросла приблизно на 60 \%, до більш ніж половини трильйону євро на рік (Salem, 2020, с. 1).

32011 р. головним економічним інструментом «м'якої сили» щодо Албанії, Болгарії та Румунії стала платформа співпраці «16+1». Вона $\epsilon$ унікальною для КНР, оскільки, як зазначалося, зазвичай Китай не підтримує блокового або багатостороннього підходу, а віддає перевагу торговельно-економічній взаємодії на двосторонньому рівні. Платформа «16+1» з'явилася з ініціативи Китаю для розвитку політико-економічних і культурних взаємозв'язків з 16 державами Центрально-Східної та Південно-Східної Європи. У 2012 р. у Варшаві відбувся перший саміт, у якому, крім Китаю, взяли участь 11 країн-членів (Болгарія, Румунія, Хорватія, Словенія, Чехія, Словаччина, Латвія, Естонія, Литва, Угорщина, Польща) й п'ять держав-кандидатів у члени СС - Албанія, Боснія і Герцеговина, Македонія, Чорногорія та Сербія (Oudenaren, 2018). Китайська сторона запропонувала європейським партнерам створити спільний секретаріат, а в майбутньому і міжнародну організацію, але європейські 
учасники вважали за краще проводити регулярні саміти на базі неформальної переговорної платформи співпраці. На саміті 2018 р. в Болгарії було зазначено, що темпи зростання торговельних угод між Китаєм i країнами-учасницями були вищими, ніж між Китаєм і СС загалом. Багато в чому це пояснюється вигідним місцем розташування Албанії, Болгарії та Румунії, оскільки через їх території проходять важливі транзитні шляхи, які в перспективі необхідні Китаю для реалізації проекту «Один пояс - один шлях». Наразі активно розвиваються вантажні перевезення. Мережа залізниць пов'язала 43 китайських міста з 42 містами в 14 європейських країнах (Oudenaren, 2018). 3 урахуванням фінансових можливостей і економічних потенціалів країни-учасниці платформи «16+1» сконцентрувалися на окремих напрямах співпраці. Наприклад, Болгарія сподівається на інтенсифікацію сільськогосподарської галузі, а Румунія сподівається на реалізацію великих енергетичних проектів, зокрема в атомній галузі (Oudenaren, 2018). Важливою ланкою для доставляння товарів на європейські ринки китайське керівництво вважає залізничне сполучення. Для цього планується з'єднати ініціативу «Один пояс - один шлях» 3 Транс'європейською транспортною мережею (проєкт створення автомобільних, залізничних, повітряних і водних транспортних сполучень) і поширити іiї на Західні Балкани (Rong, 2018). Також для розвитку послуг контейнерних поїздів із залізничним сполученням в країни ЄС Китай планує побудувати мережу нових логістичних центрів. Китай активно просуває модель розвитку інфраструктури, що призводить до збільшення боргових зобов'язань в межах «16+1». Пропозиція Пекіна, безсумнівно, є вигідною для деяких країн регіону, але має значні обмеження щодо низьких відсотків та довгострокових китайських кредитів, які є особливо привабливими для урядів з обмеженим доступом до міжнародних фінансових ресурсів і фондів СС. Китайські кошти також не передбачають вимоги до внутрішніх реформ, що вигідно відрізняє їх від пропозицій Світового банку, МВФ та ін. (Oudenaren, 2018).

Найбільшого успіху формат «16+1» досяг безпосередньо в рамках зміцнення двосторонніх міждержавних відносин. Масштаби діяльності Китаю щодо країн-новачків $С С$ поступово переходять до політичної сфери й стратегічних об'єктів. Також це розраховано на те, що з часом економічна залежність від Китаю призведе до політичної - тісніші зв'язки Пекіна з бідними країнами ЄС будуть впливати на політику ЄС і можуть бути використані для підриву єдиної думки блоку.

Пандемія COVID-19 є чудовим прикладом китайської економічної дипломатії. Звинувачений у спробі приховати проблему, Китай започаткував так звану «маскову дипломатію», щоб представити себе як відпові- 
дального міжнародного актора. Китай швидко почав надавати допомогу в різних формах завдяки своїм економічним можливостям. Сі Цзіньпін пообіцяв, що коли вакцина буде готова, вона стане загальнодоступною. Це дуже контрастувало з заявою Дональда Трампа про придбання вакцини, розробленої у Німеччині, щоб вперше використати іiі у США. На думку Д. Кармінаті, «можна стверджувати, що країни, які отримують допомогу від Китаю, не забудуть іiі» (Carminati, 2020, с. 1).

Одночасно зрив глобального ланцюга постачань через пандемію COVID-19 виявив залежність СС від Китаю в багатьох стратегічних напрямах і окреслив важливість розширення європейської автономії на сфери, безпосередньо не пов'язані з жорсткою безпекою. Завдання полягає в тому, щоб стати самодостатніми у медичному та фармацевтичному виробництві, виробництві комп'ютерів, акумуляторів, електричних транспортних засобів та вітрогенераторів (Salem, 2020, с. 2). Іншим завданням $є$ захист критично важливих технологій європейських фірм від китайських інвесторів. Придбання європейських високотехнологічних компаній дало можливість провідним підрозділам Китаю просунути китайське технологічне лідерство, набувши досвіду людського капіталу, таким чином збільшуючи їх технологічні ноу-хау та здатність досягти промислового лідерства (Salem, 2020, с. 2).

Однак експансія Пекіна в Європі викликає щоразу більше невдоволення в $\mathrm{CC}$, причому настільки, що останнім часом європейці почали реагувати відкрито. Головною мішенню для критики є співпраця КНР зі східноєвропейськими країнами-членами СС та країнами-кандидатами. У 2017 р. міністр закордонних справ Німеччини Зігмар Габріель назвав політику Пекіна в Свропі загрозою єдності СС. Він закликав до розробки єдиної стратегії ЄС щодо Китаю на континенті та до визначення необхідних заходів у відповідь, щоб не допустити внутрішнього розколу щодо «китайського питання». Заяви Габріеля викликали бурхливу реакцію з боку КНР. Але, що важливо, Пекін не став спростовувати прагнення налагодити діалог зі східноєвропейськими країнами в обхід Брюсселя. Свропейські політики вбачають загрозу з боку Пекіна та вживають відповідних заходів. Влітку 2017 р. французький президент Еммануель Макрон закликав розробити жорсткіші правила контролю з боку ЄС щодо іноземних інвестицій, особливо коли йдеться про стратегічно значущі активи. Макрон вказував на китайські інвестиції як на предмет найбільших побоювань. Його підтримали канцлер Німеччини Ангела Меркель і глава Єврокомісії Жан-Клод Юнкер. ЄС почав розробку спільної позиції щодо китайських інвестицій. Але до сьогодні така стратегія так і не з'явилася, не в останню чергу через протидію деяких партнерів КНР в Болгарії та Румунії («Китай активизируется», 2019). 
Отже, активність Китаю в економічній сфері в Болгарії та Румунії $\epsilon$ об'єктивно обмеженою їхньою приналежністю до ЄС. Існують розбіжності та невирішені проблеми й між РФ та КНР. Пекін особливо не влаштовують занадто високі ціни на електроенергію, а російська сторона сприймає активізацію виходу Китаю на ринок Чорномор'я як економічну загрозу: Росія може не тільки залишитися периферією Заходу, а й стати периферією Китаю. КНР добре розуміє й користується зацікавленістю країн Чорноморського регіону в створенні нових точок опори у відносинах з глобальними силами та на цій основі прагматично розглядає простір між Чорним морем і Центральною Азією як потенційно вигідне вкладення своїх політичних та економічних ресурсів.

\section{Гуманітарне співробітництво Китаю з країнами ЧМР}

Про ефективність впливу китайської «м'якої сили» на російське суспільство можна говорити, порівнюючи динаміку емоційного сприйняття КНР та інших країн світу. У 1990-ті рр. погляди росіян були цілком і повністю прикуті до Заходу, а країни Сходу не викликали у них особливого інтересу, але після 2001 р. ситуація почала швидко змінюватися (Галенович, 2010).

За даними різних соціологічних досліджень, найкраще в цей час росіяни ставляться саме до Китаю. У 2014 р. російські опитування засвідчили, що 65 \% росіян позитивно відгукувалися щодо КНР, тоді як частка негативних відповідей склала всього $14 \%$. Опитування Pew Center наступного 2015 р. засвідчило, що $51 \%$ росіян позитивно сприймає КНР (негативно - 37 \%). Це значно відрізняється від опитувань 2014 р., але все ще є одним з високих результатів для РФ. Росіяни продовжують позитивно згадувати радянсько-китайську дружбу та боротьбу з західним ліберальним впливом (Laruelle, \& Luo, 2020, с. 1).

На думку Ларуелль та Луо, «Тридцять років після розпаду Радянського Союзу, Комуністична партія Китаю (КПК) та китайські націоналісти все ще травмовані зникненням колишнього СРСР, яке вони трактують як геополітичну трагедію, якої повинна уникати партія-держава Китаю» (2020, с. 2). Разом з цим Сі Цзіньпін, який прийшов до влади у 2013 р., заявив, що «ніхто не міг би протистояти розпаду СРСР у 1991 р.» (Laruelle, \& Luo, 2020, с. 2). Рупор КПК «Реople Daily» регулярно висвічує образ Володимира Путіна як приклад «російського патріота, який наполегливо працює над просуванням культури, історії та військової сили своєї країни» на тлі того, що описується як «вторгнення західних ліберальних думок». За словами доктора Лі Лінга з Академії суспільних наук, КПК повинна вчитися в адміністрації Путіна просуванню «мілітаристського патріотичного виховання», готовності громадян до самопо- 
жертви за свою націю та гордості за національну ідентичність (Laruelle, \& Luo, 2020, c. 2).

У Чорноморському регіоні Росія є єдиною країною, крім КНР, яка здатна застосовувати свою «м'яку силу» (Nye, 2013). За таких обставин можливості Росії у цьому випадку приблизно дорівнюють китайським. Згідно з глобальним рейтингом «м'якої сили» 2018 р., складеним британським агентством Portland Communications, Китай посів у ньому 27-е місце, а Росія - 28-е («Global ranking of soft power», 2018).

Але така глибока культурна взаємодія як з РФ є винятковою у відносинах КНР $з$ державами ЧМР. В усіх інших країнах головним інструментом реалізації політики КНР у гуманітарній сфері є Інститути Конфуція.

Складно відокремити стратегію залучення Китаю від його економічної сили. Мало країн мають достатнє фінансування, щоб відкривати культурні центри в усьому світі й сприяти обміну для взаєморозуміння. Сьогодні у світі працює понад 500 Інститутів Конфуція. Інститути Конфуція в кожній країні закладають основу мережі впливу. Їхнє офіційне завдання полягає у викладанні китайської мови, зокрема, місцевим елітам, які покликані брати участь у майбутніх обмінах з Китаєм. Але насправді вони діють як агенти впливу, проводячи лінію Комуністичної партії Китаю та захищаючи інтереси китайської держави. Програма створення інститутів Конфуція почалася в 2004 р. Спочатку вона була спрямована на країни Центральної Азії, пострадянський простір і Східну Свропу. Перший Інститут Конфуція було відкрито у Білорусі в 2006 р. (Яньдун, 2011, с. 10). Хоча деякі Інститути Конфуція було закрито через побоювання втручання до академічної свободи університетів. Більшість країн, що розвиваються, прихильно ставляться до існування таких закладів на своїй території, враховуючи те, що вони відмінно навчають китайської мови, а також пропонують стипендії для навчання в Китаї.

Політичне керівництво КНР вважає, що створення Інститутів Конфуція $є$ потужним каналом сприяння культурному обміну між Китаєм та іноземними державами (Цзиньпин, 2017). Тому ці інститути можна назвати важливою складовою частиною зовнішньої пропагандистської роботи КНР.

Росія випередила всі європейські країни за кількістю Інститутів Конфуція (за винятком Великобританії) (Ягья, \& Минфу, 2015, с. 85). Йдеться про укорінення в масовій свідомості своєрідної звички озиратися на Китай, яка постійно присутня в політичному житті у формі психологічно стійкого стереотипу. Ця мета забезпечується, з одного боку, обережною, але разом 3 тим і недвозначною підтримкою незалежного зовнішньополітичного курсу Росії щодо Заходу (Edney, 2012, с. 910). 
Інститути Конфуція користуються не меншим успіхом у Албанії, Болгарії та Румунії, де вивчається китайська мова, проводяться виставки, концерти, здійснюються інші культурні проекти (Rong, 2018). Також зазначається розширення академічних контактів: обмінні програми вчених і викладачів, навчання іноземних студентів у китайських вузах тощо (Mattern, 2005, c. 601).

3 метою популяризації китайської культури та китайської мови, створення та підтримки позитивного образу Китаю на Кавказі Пекін активно працює в напрямі культурної дипломатії. Крім створених інститутів Конфуція (в Сревані - в 2009 р., у Тбілісі - в 2010 р., у Баку - в 2011 р.), створюються школи з вивчення китайської мови та програми культурних обмінів між університетами (Цзиньпин, 2014, с. 47). Також важливу роль у розвитку двосторонніх культурних зв'язків відіграє грузино-китайський культурний центр «Шовковий шлях», який було засновано в 1992 р. Основною метою центру є розвиток і поглиблення культурних та економічних зв'язків між двома країнами (Бабаян, 2011).

Окрім Інститутів Конфуція, додатковий формат взаємодії пропонує Академія суспільних наук (китайський аналітичний центр із питань політики, пов'язаний з Державною радою КНР). Особлива увага звертається на науково-технічні контакти, тому в 2015 р. Академія суспільних наук КНР виступила з ініціативою створення в рамках співпраці «16+1» мережі мозкових центрів - «Think Tanks Network». Основне завдання цих інтелектуальних центрів визначалося прагненням Китаю отримати доступ до інтелектуального капіталу країн Східної Європи. У квітні 2017 р. було створено незалежний мозковий центр «China-CEE Institute», метою якого $€$ інтелектуальне співробітництво в рамках платформи «16+1» (Шишелина, 2019, с. 9).

Інструменти гуманітарної сили включають не тільки привабливу освітню систему, а й наукову та технічну діяльність (Цзайци, 2009, с. 150). Ступінь розвитку інфраструктури гуманітарного співробітництва КНР з країнами регіону добре видно на прикладі РФ. Ї̈̈ складають: Російсько-китайське товариство, Російсько-китайський фонд розвитку культури та освіти, Російсько-китайський комітет дружби, миру та розвитку, Російський культурний центр в Пекіні, Китайський культурний центр в Москві (Карпов, 2013).

Інша комплексна ініціатива Китаю «Один пояс - один шлях» (BRI) - це амбітний план підключення світу до «Серединної держави», представлений як корисний для всіх залучених партнерів. Одним із принципів є єднання різноманітних громад і культур; і навіть у цьому випадку він підтримується економічними ініціативами та стимулами (Carminati, 2020 , с. 1). Слід зазначити, що порівняно з РФ або європейськими кра- 
їнами кавказькі республіки в цілому мали менше значення для Китаю доти, доки не стали важливим напрямом китайської ініціативи «Одного поясу - одного шляху».

Серед додаткових інструментів китайської політики можна назвати просування брендів провідних китайських компаній («Хiaomi», «Huawei», «Aliexpress», «Haier»), що є важливим напрямком економічної експансії Китаю в Європі. У сфері телекомунікацій Китай ввів платіжну систему China Union Pay, що означає проникнення до Свропи системи для міжнародних грошових переказів, яку не зможуть заблокувати США (Rong, 2018).

Країни, які отримали щедру та своєчасну допомогу, молодь, що отримує доступ до освітніх та професійних можливостей, пропонованих Інститутами Конфуція, економічні вигоди, очікувані від добудови швидкісної залізниці або нової мережі 5G (і навіть поєднання всього цього), не можуть не розвивати доброзичливість до Китаю. I особливо це правильно, якщо події будуть корисними і для населення, і для політичних лідерів (Carminati, 2020, с. 2).

Стосовно гуманітарного аспекту політики Китаю в ЧМР слід зазначити, що кожен успіх Китаю знецінювався певними подіями всередині країни. Наприклад, позитивний ефект Олімпіади-2008 послабили репресії проти китайських правозахисників, а після вдалої виставки ЕКСПО-2010 в Шанхаї світ здивував судовий вирок лауреату Нобелівської премії Лю Сяобо. Навіть вкладання мільярдів доларів у створення міжнародного новинного телемовлення Сіньхуа та Центрального телебачення не мало великого успіху серед іноземної аудиторії (Hongyi, \& Yiyi, 2012, c. 114).

Тому багато експертів вважають, що зараз Китай тільки розробляє свою національну концепцію ціннісної взаємодії з іншими культурами. Однак пропагандистські заходи не є винятковим знаряддям авторитарних акторів. Якщо навіть наміри Пекіна не є послідовно чесними та прозорими, його вирізняє те, що КНР дійсно вміє адаптувати свої стратегії до кожної окремої країни.

\section{Висновки та прогнози}

Підсумовуючи успіхи КНР у Чорноморському регіоні, можна виділити проект співпраці «16+1», який значно зміцнив зв'язки Китаю 3 Албанією, Болгарією та Румунією. Однією з невдач КНР є, насамперед, економічна експансія Китаю в Європі, яка викликає щораз більше невдоволення ЄС і через що Євросоюз почав розробку спільної позиції щодо китайських інвестицій.

На глобальному рівні Китай зацікавлений у можливості створення альянсу з Росією, Туреччиною, Іраном та Пакистаном. Введення Спо- 
лученими Штатами жорстких економічних санкцій проти Росії та Ірану змусили їх «стукати у двері» Пекіна. Якщо США та їх союзники спільно спробують дати відсіч такому об'єднанню, світ може побачити найбільш негативний сценарій - нову «холодну війну» чи навіть ядерну війну. Сучасний світ здається неврівноваженим і багатополюсним, i тому, на думку деяких науковців, вірогідність війни стає все більш імовірною (Raja \& Dar, 2020).

Реалістичний сценарій передбачає подальший «крен» КНР до РФ як актора, що має на меті створити власний центр сили, опозиційний «колективному Заходу». Але амбіції Москви не супроводжуються відповідним інструментарієм та ресурсами, тому союз з Китаєм може призвести до банд-вагонінгу РФ й навіть до іiї переходу у стан «молодшого», залежного, партнера. Стратегічну цінність Росії для китайського керівництва не слід переоцінювати; вона має свої межі, у тому числі й 3 питань України (зокрема Криму), інвестиційного співробітництва, невизнаних республік Закавказзя (Абхазії та Південної Осетії). Досі залишається незрозумілим, де місце Росії у грандіозному китайському проєкті «Один пояс - один шлях», який вона (Росія) все ж підтримує, розраховуючи, що трансконтинентальні транспортні коридори стануть найважливішою складовою частиною нової системи міжнародних економічних транзитів.

Позитивний для КНР сценарій пов'язаний з тим, що Китай продовжить вдалу політику в ЧМР: виходячи зі специфіки будь-якої країни Чорноморського регіону зосереджувати увагу на тих зовнішньополітичних інструментах, які принесуть йому найбільшу вигоду. Щодо європейських країн акцентують на економічних інструментах, на Кавказі - на дипломатії. Україна, Молдова, Албанія, Болгарія та Румунія вбачають у «китайському факторі» можливість подолати економічне відставання від своїх західних партнерів. За останні роки відчутне зростання не тільки економічного, але й політичного, а також культурного співробітництва, якому китайська сторона надає великого значення. Перевагу КНР надає країнам, які демонструють стабільну політичну ситуацію, розвинений ринок, дешеву й освічену робочу силу, що привертає китайських бізнесменів і дає надії на ефективну реалізацію глобального проєкту «Один пояс - один шлях». Очевидно, що Молдова та Україна програють у цьому сенсі Болгарії та Румунії. Політика Китаю в рамках платформи співпраці «16+1» характеризується чисельними освітніми обмінами, культурними форумами, зростаючим туристичним обміном. Таким чином Китай створює нову зону впливу на всьому європейському континенті, що підсилює його позиції в глобальній конкурентній боротьбі за ринки 
сировини та збуту продукції, особливо в умовах конфронтації з США. Незважаючи на те, що Китай має незначний історичний досвід у геополітичних зв'язках з кавказькими державами, КНР має намір змінити ситуацію (Цзиньпин, 2014). Зміцнюючи зв’язки з цими трьома країнами, Китай робить це, не викликаючи невдоволення таких регіональних гравців, як РФ та ТР. Пекін не втручається у внутрішні справи держав, що сприймається ними як знак поваги та надихає держави до більш поглибленої співпраці. Сьогодні й у перспективі Пекін буде, насамперед, робити ставку на свій найконкурентоспроможніший зовнішній ресурс - економічне проникнення.

\section{Список посилань}

1. 20 років стратегічного партнерства Пекіна і Києва. Роль України у військовій модернізації Китаю. (2014). Взято 3 http://mil.news.sina.com. $\mathrm{cn} / 2014-01-15 / 0935760158 . \mathrm{html}$

2. Бабаян, Д. С. (2011). Роль и место Южного Кавказа в геополитической повестке Китайской Народной Республики. 21-ц̆ BEK, 2 (18), 66-92. Взято 3 https://cyberleninka.ru/article/n/rol-i-mesto-yuzhnogo-kavkaza-vgeopoliticheskoy-povestke-kitayskoy-narodnoy-respubliki/viewer

3. Газпром возобновил поставки газа в Китай по Силе Сибири-1. (2020, 1 апреля). Neftegaz.RU. Взято 3 https://neftegaz.ru/news/Trading/539674gazprom-vozobnovil-postavki-gaza-v-kitay-po-sile-sibiri-1/

4. Галенович, Ю. М. (2010). Взгляд на Россию из Китая. Прошлое и настоящее России и наших отношений с Китаем в трактовке китайских ученыхх. Москва: Время.

5. Голова КНР Сі Цзіньпін визначив основні перспективні сфери співробітництва з Туреччиною. (2015, 31 липня). CRIonline. Взято з http://ukrainian. cri.cn/841/2015/07/31/2s40865.htm

6. Давыдов, Ю. П. (2004). Понятие «жесткой» и «мягкой» силы в теории международных отношений. Международные процессы, 4, 69-80.

7. Договор о добрососедстве, дружбе и сотрудничестве между Российской Федерацией и Китайской Народной Республикой от 16 июля 2001 года. Президент России. Взято з http://www.kremlin.ru/supplement/3418

8. Карпов, М. В. (2013). Современная Россия в поле «мягкой силь»» Китая: некоторые аспекты теории и практики взаимодействия. Страны СНГ и Балтии в глобальной политике Китая. Москва: РИСИ.

9. Китай активизируется в Европе. (2019, Март 24). Информащионное сопротивление. Правда належсть вільним. Взято $3 \mathrm{https} / /$ sprotyv.info/ news/kitaj-aktiviziruetsya-v-evrope

10. Китай недоволен вмешательством Запада в дела Украины. (2013, Декабрь 13). Зеркало недели. Взято з http://zn.ua/WORLD/kitay-nedovolenvmeshatelstvom-zapada-v-dela-ukrainy-134976_html

11. Клусман, У. (2014, Март 21). Тень Китая нависла над Украиной: Пекин поддерживает Москву. InoPressa. Взято 3 https://www.inopressa.ru/ article/21Mar2014/spiegel/china.html 
12. Концепция внешней политики Российской Федерации. (2019). Министерство иностранных дел РФ. Взято з http://www.mid.ru/brp_4.nsf/0/6 D84DDEDEDBF7DA644257B160051BF7F

13. Корсунський, С. (2020, 18 серпня). Китай вибирає стратегію відносин зі Сполученими Штатами. Дзеркало тижня. Взято $3 \mathrm{https} / / \mathrm{zn} . \mathrm{ua} / \mathrm{ukr} /$ international/seredinnij-shljakh-skhodu.html

14. Леонова, О. Г. (2013). Мягкая сила - ресурс внешней политики государства. Обозреватель-Observer, 4, 27-40.

15. Мавріна, О. С. (2012). Стратегічне партнерство в зовнішньополітичній практиці Туреччини. Сходознавство, 59, 48-81. Взято 3 http://nbuv.gov. ua/UJRN/Skhodoz_2012_59_8

16. Очередная пресс-конференция у официального представителя МИД КНР Хуа Чуньин. (2014, 25 февраля). Ministry of Foreign Affairs of the People's Republic of China. Взято 3 http://www.fmprc.gov.cn/rus/xwfw/fyrth/lxjzhzh$\mathrm{dh} / \mathrm{t} 1133381 . \mathrm{shtml}$

17. Покась, М. С. (2017). Україно-китайські відносини. У І. М. Коваль, О. І. Брусиловська, В. А. Дубовик (Ред.). Стратегічна культура та зовнішня політика України, 138-153. Одеса: Одеський національний університет імені I. I. Мечникова.

18. Роллан, Н. (2018). Влияние Китая в странах Восточной Европы и Южного Кавказа. Notes de l'Ifri Russie.Nei.Visions, 112. Взято 3 https://www. ifri.org/sites/default/files/atoms/files/vliyanie_kitaya_v_stranah_vostochnoy_ evropy_i_yuzhnogo_kavkaza.pdf

19. Русакова, О. Ф. (2010). Концепт «мягкой» силы (soft power) в современной политической философии. Научный ежегодник Института философии и права Уральского отделения РА, 10, 173-192.

20. Терещенко, Ю. (2014, Март 28). Потребности Вооруженных сил - главный приоритет «Укроборонпрома». Зеркало недели. Взято $3 \mathrm{http}: / /$ gazeta.zn.ua/internal/potrebnosti-vooruzhennyh-sil-glavnyy-prioritetukroboronproma-_html

21. Товарооборот России с Китаем растёт за счёт импорта. (14 апреля 2020). EurAsiaDaily. Взято 3 https://eadaily.com/ru/news/2020/04/14/tovarooborotrossii-s-kitaem-rastyot-za-schyot-importa

22. Торговельно-економічне співробітництво між Україною та Китаєм. (2020, Серпень 5). Сайт Посольства Украйни в Китайській Народній Республіиі та в Монголії (за сумісництвом). Взято 3 https://china.mfa.gov. ua/spivrobitnictvo/186-torgovelyno-jekonomichne-spivrobitnictvo-mizhukrajinoju-ta-kitajem

23. Тымчук, Д. (2017). Украина-Китай: бег по лезвию «технологической бритвы». Flot. Взято 3 http://flot2017.com/posts/new/ukrainakitaj_beg_po_ lezviju_tehnologicheskoj_britvy_

24. Цзайци, Л. (2009). «Мягкая сила» в стратегии развития Китая. Политические исследования, 4, 149-155.

25. Цзиньпин, С. (2014). Великое возрождение китайской нации - величайшая мечта китайской нации с начала нового времени. $O$ государственном управлении, 47-50. Пекин: Издательство литературы на иностранных языках. 
26. Цзиньпин, С. (2017). Полный текст доклада, с которым выступил Си Цзиньпин на 19-м съезде КПК. 19-й Всекитайский съезд КПК. Взято $з$ http://russian.news.cn/2017-11/03/c 136726299.htm

27. Шевырев, И. (2011). Украина и Китай: 20 лет вместе. Кіевскій телеграфъ. Взято $3 \mathrm{http} / /$ telegrafua.com/country/12879/

28. Шишелина, Л. Н. (2019). Центральная Европа в стратегии Китая. Научно-аналитический Вестник Института Европь РАН, 2. Взято з https:// cyberleninka.ru/article/n/tsentralnaya-evropa-v-strategii-kitaya

29. Ягья В. С., \& Минфу, Л. (2015). Институт Конфуция как фактор «мягкой силы» во внешней политике КНР в XXI веке. Международная жизнь, 7, 84-93.

30. Яньдун, Л. (2011). Совместная работа для устойчивого развития институтов Конфуция: Программная речь на V съезде Институтов Конфуция. Институт Конфуция, 1 (4), 10 (русско-китайская версия).

31. Albert, E. (2018, February 9). China's Big Bet on Soft Power. Council on Foreign Relations. Retrieved from https://www.cfr.org/backgrounder/chinasbig-bet-soft-power

32. Barnett, M., \& Duvall, R. (2005). Power in International Politics. International Organization, 59 (1), 39-75. Retrieved from https:/www.cambridge.org/ core/journals/international-organization/article/power-in-international-politics/F5F3C74D30A12A5C4CC9B4EFEA152967

33. Callahan, W., \& Barabantseva, E. (Eds.). (2012). China Orders the World: Normative Soft Power and Foreign Policy. Johns Hopkins University Press.

34. Carminati, D. (2020, July 3). The State of China's Soft Power in 2020. E-International Relations. Retrieved from https://www.e-ir.info/2020/07/03/thestate-of-chinas-soft-power-in-2020/

35. China Makes Proposals on Political Solution to Ukraine Crisis. (2014, March 16). Ecns.cn. Retrieved from http://www.ecns.cn/2014/03-16/105061.shtml

36. Chinese State Councilor, U.S. National Security Advisor Discuss Ukraine over Phone. (2014, March 6). Global Times. Retrieved from http://www. globaltimes.cn/content/846662.shtml

37. Edney, K. (2012). Soft power and the Chinese propaganda system. Journal of Contemporary China, 21 (78), 899-914.

38. Global Ranking of Soft Power. (2018). Portland Communications. Retrieved from https://portland-communications.com/publications/a-global-ranking-of-soft-power-2018/

39. Hongyi, L., \& Yiyi, L. (Eds.). (2012). China's Soft Power and International Relations. London and New York, NY: Routledge. Retrieved from https:// www.researchgate.net/publication/276526519_Hongyi_Lai_and_Yiyi_Lu_ eds_China's_Soft_Power_and International_Re-lations

40. Laruelle, M., \& Luo, Wēi (Josh) (2020). Soviet Legacy as Soft Power. Chinese Reception of Russian Political and Cultural Influence. PONARS Eurasia, Policy Memo 667. Retrieved from https://www.ponarseurasia.org/memo/soviet-legacy-soft-power-chinese-reception-russian-influence

41. Mattern, J. (2005). Why "Soft Power" Isn't So Soft: Representational Force and the Sociolinguistic Construction of Attraction in World Politics. Millenium - Journal of International Studies, 33 (3), 583-611. 
42. Nye, J. (2004). Soft Power. The means to success in world politics. N.Y.: Public Affairs.

43. Nye, J. (2011). The Future of Power. N.Y.: Public Affairs.

44. Nye, J. (2013, April 29). What China and Russia Don't Get About Soft Power. Foreign policy. Retrieved from https://foreignpolicy.com/2013/04/29/whatchina-and-russia-dont-get-about-soft-power/

45. Oudenaren, J. (2018, September 4). Why China Is Wooing Eastern and Central Europe. The National Interest. Retrieved from https://nationalinterest.org/ feature/why-china-wooing-eastern-and-central-europe-30492

46. Palanisami, R. (2020, August 10). Opinion - Making Sense of China's 'Wolf Warrior' Diplomacy. E-International Relations. Retrieved from https://www.e-ir.info/2020/08/10/opinion-making-sense-of-chinas-wolf-warrior-diplomacy/

47. Raja, R., \& Dar, Z. A. (2020, August 9). Asian Security amid China's Dominance. E-International Relations. Retrieved from https://www.e-ir. info/2020/08/09/asian-security-amid-chinas-dominance/

48. Rong, G. (2018, April 25). China launches «China-CEE Institute» think tank in Hungary. Official website for China Global Television Network (CTGN LIVE). Retrieved from https://news.cgtn.com/news/3d4d444f78597a4d/ share_p.html

49. Salem, K. (2020, August 8). Opinion - Europe and China's Growing Assertiveness. E-International Relations. Retrieved from https://www.e-ir. info/2020/08/08/opinion-europe-and-chinas-growing-assertiveness/

50. Wu, Yipin. (2020). Dynamics of policy change in authoritarian countries: a multiple-case study on China. Journal of Public Policy, 40, 236-258. DOI: https://doi.org/10.1017/S0143814X18000351 


\section{РОЗДІЛ 8 \\ КРАЇНИ ЧОРНОМОРСЬКОГО РЕГІОНУ У ЗОВНІШНІЙ ПОЛІТИЦ ЯПОНІї: ІСТОРІЯ ТА СУЧАСНІСТЬ}

(Удовік В. В.)

\section{Bcmyn}

Японія - глобальна держава, активний член ООН та Групи Семи, третя економіка світу, міжнародний донор, військовий союзник США, партнер Європи, лідер у Східній Азії. Це - основні тези, які спадають на думку, коли ми говоримо про Японію, ії найважливіші досягнення та діяльність на міжнародній арені. Водночас, мало відомо про відносини Японії з країнами Чорноморського регіону. Проте, незважаючи на віддаленість країни Вранішнього Сонця від цього геополітично важливого регіону та той факт, що він з'явився у зовнішньополітичній стратегії Японії тільки у XXI ст., історія зв'язків Японської держави з причорноморськими країнами сягає середини XIX - початку XX ст.

У 1855 р. було підписано Сімодський трактат між Японією та Російською імперією. 1882 рік вважають роком дружби Сербії та Японії 3 огляду на те, що цього року було здійснено перше дипломатичне листування між сербським королем Міланом Обреновичем та японським імператором Мейдзі. Японсько-турецькі відносини засновані не тільки на контактах за часів Оттоманської імперії на кшталт візиту японського принца Комацу-но-мія Акіхіто до Константинополя в 1887 р., а й на допомозі, наданій японським урядом та підданими Японської імперії після краху оттоманського фрегата «Ertugrul» біля берегів Японії у 1890 р., яка стала символом дружби між двома народами.

Дипломатичні відносини Японії з Грецією було встановлено завдяки підписанню Договору про дружбу, торгівлю та судноплавство в 1899 p. У 1902 р. Японією було встановлено перший дипломатичний контакт з Румунією, завдяки чому обома країнами було засновано дипломатичні представництва: Румунією в Токіо - у 1921 р., Японією в Бухаресті - у 1922 р. Японія де-факто визнала незалежність Грузинської, Азербайджанської та Вірменської республік у 1920 р., а вірменку Діану Абгар призначили почесним консулом в Японській державі. У 1939 р. Японія та Болгарія заснували дипломатичні місії.

Українсько-японські контакти вибудовувалися за трьома напрямами. По-перше, у 1902-1904 рр., 1905-1908 рр. та 1925-1937 рр. в Одесі було відкрито японське консульство. По-друге, це контакти україн- 
ців 3 японцями на Далекому Сході в першій половині XX століття, а саме в українській колонії «Зелений Клин», що охоплювала територію Примор'я та Приамур'я, та в Маньчжурії (сучасний Китай). По-третє, відомо, що у 1917 р. Японським посольством у Петрограді було направлено дипломатичну та військову місії до Києва, а протягом 1920 р. велося листування між представниками Української Народної Республіки та японськими дипломатами в Європі.

У наші часи Японія зацікавлена в розбудові співробітництва 3 Чорноморським регіоном за низкою об'єктивних причин. Перш за все, Японію приваблює географічне розташування Чорного моря, яке є перехрестям між Свропою, Центральною Азією та Близьким Сходом. У політичному плані Чорноморський регіон $є$ майданчиком для просування геополітичних інтересів таких гравців як НАТО на чолі зі США, що $\epsilon$ головним військово-політичним партнером Японії, та Росією (iї безпосереднім сусідом), у стосунках з якою існує низка невирішених питань. У безпековому вимірі Японія дотримується позиції невизнання зміни статус-кво шляхом застосування сили, а також закликає до дотримання норм та принципів міжнародного права. Як острівна держава Японія докладає зусиль задля забезпечення свободи мореплавання в усіх морях, включно з Чорним та Азовським. В економічному плані ОЧЕС є для Японії привабливим ринком з 333 млн. споживачів та сукупним ВВП у розмірі 2,8 трлн. дол. США, що становить $14 \%$ від європейської та 4 \% від світової економіки (Market Intelligence, 2018).

Зовнішня політика Японії у постбіполярний період: перетворення у «нормальну краӥну»

Важливою передумовою для розвитку відносин Японії з країнами Чорноморського регіону стала загальна активізація ії̈ зовнішньої політики. Після краху біполярної системи міжнародних відносин Японія стала на шлях комплексної перебудови своєї зовнішньополітичної стратегії з метою перетворення на «нормальну країну» («normal country»). У цьому контексті «ненормальність» Японії пов’язана з неможливістю прийняття деяких політичних рішень через обмеження ролі та функцій іiї військових сил, особливостями бюрократичної системи, поширенням антимілітаристських ідей, складнощами у відносинах з іншими азійськими країнами, безпековими гарантіями з боку США тощо (Soeya, Welch, \& Tadokoro, 2011, c. 4-7).

Японський дослідник К. Іванага зазначає, що еволюція зовнішньої політики Японії в постбіполярний період характеризується як «видозмінена безперервність» («modified continuity»). Він проводить паралель між Японією та Німеччиною, яка випередила Японію й перетворилася на «нормальну країну» ще до 1990-х рр. завдяки участі в бойових опе- 
раціях на Балканах та в Косово. К. Іванага зазначає, що після закінчення холодної війни Японія змогла перейти від «дипломатії чекової книжки» («checkbook diplomacy»), що полягає в наданні економічної допомоги іншим країнам з метою зміцнення свого впливу на міжнародній арені, до участі в небойових діях в Азії. Разом з тим, дослідник вважає, що цього недостатньо для перетворення Японії на «нормальну країну» та наголошує на необхідності формулювання нової великої стратегії в зовнішній політиці Японії (Iwanaga, 2011, с. 59-61).

Центральною подією цього напряму можна вважати прийняття у 2013 р. прем’єр-міністром Японії С. Абе «Стратегії національної безпеки», згідно з якою фундаментальним принципом національної безпеки Японії став «активний внесок до миру на основі принципу міжнародного співробітництва». Відповідно до цієї стратегії, Японія докладатиме зусиль 3 метою «поліпшення глобальної безпеки та побудови мирного, стабільного та процвітаючого міжнародного співтовариства шляхом зміцнення міжнародного порядку, заснованого на універсальних цінностях і правилах та провідної ролі Японії у вирішенні міжнародних конфліктів» (National Security Strategy, 2013). Саме такий підхід забезпечив залучення Японії до вирішення питання окупації Криму, підвищив іiі політичну присутність у Чорноморському регіоні та сприяв зміцненню українсько-японських відносин.

3 огляду на те, що Організація Чорноморського економічного співробітництва має гетерогенний характер та складається з членів Європейського союзу, НАТО, ОБСЄ, СНД, ГУАМ, Східного партнерства тощо, відносини Японії з причорноморськими країнами наприкінці XX-го століття вибудовувалися на двосторонній основі з урахуванням стратегії Японії стосовно ЄС та пострадянських країн.

У цьому контексті слід зазначити, що Японія стала першою азійською країною, яку запросили взяти участь у Конференції з питань безпеки та співробітництва в Європі (зараз - Організація з безпеки та співробітництва в Свропі). У 1996 р. Японія стала спостерігачем Ради Свропи та активним членом форуму «Зустріч Азія - Свропа» (ACEM). Відносини між Японією та ЄС розвивалися на основі таких ключових документів, як Спільна декларація 1991 р., План дій щодо співробітництва між ЄС та Японією 2001 р., Угода про стратегічне партнерство 2018 р. та Угода про економічне партнерство, що набула чинності у 2019 р. Крім того, Японія розвиває відносини з європейськими країнами шляхом створення мікрорегіональних механізмів співпраці на кшталт форумів «Вишеградська група + Японія» та «Північно-Балтійська Вiсімка + Японія», які разом із Групою Семи стали важливою платформою 
для обговорення ситуації в Україні. Щодо відносин з НАТО, то Японія має статус глобального партнера й розвиває співпрацю з цією організацією на основі Спільної політичної заяви 2013 р. й Індивідуальної програми партнерства та співробітництва 2014 р.

Європейський фактор має позитивний вплив на розвиток відносин між Японією та країнами-членами ОЧЕС. Підтвердженням цієї тези можна вважати те, що перший візит міністра закордонних справ Японії до Румунії й Болгарії відбувся саме після їх входження до СС у 2007 р. Разом $з$ тим, підписання Україною Угоди про асоціацію з СС у 2014 р. сприяло більш активному входженню японських компаній на український ринок. Розвиток відносин Японії з НАТО та СС у напрямі стратегічного партнерства також висвітлив необхідність у більш активному залученні Японії до справ Чорноморського регіону, стабільність якого $€$ важливим елементом для забезпечення миру та безпеки в Свропі.

Щодо основних напрямів зовнішньої політики Японії на пострадянському просторі, можна зазначити таке: по-перше, після розпаду Радянського Союзу японський уряд почав активно шукати шляхи вирішення питання «Північних територій», або Курильських островів (Хабомаї, Сікотан, Кунасірі, Еторофу) та підписання мирного договору з Росією; по-друге, ця геополітична подія надала Японії можливість налагодити відносини з новими незалежними державами, а саме 3 такими членами ОЧЕС як Україна, Азербайджан, Вірменія, Грузія та Молдова; по-третє, Японія розпочала процес надання гуманітарної, фінансової та технічної допомоги пострадянським країнам i, найголовніше, вона відіграла важливу роль у процесі ліквідації ядерної зброї в Україні, Білорусі та Казахстані, а також ядерних відходів у Росії.

У 1990-х рр. було визначено стратегію розвитку відносин з пострадянськими країнами, яка включала: 1) розвиток політичного діалогу та гуманітарних обмінів; 2) надання Офіційної допомоги розвитку та гуманітарної допомоги з метою підтримки країн регіону в побудові державних інститутів, демократії та ринкової економіки; 3) заохочення економічної співпраці; 4) сприяння взаєморозумінню та культурному обміну (Уяма, Лен, \& Хiросе, 2009, с. 5-6).

На основі вищезазначеної стратегії 28 грудня 1991 р. Японія визнала усі нові незалежні держави, за винятком Грузії (ії незалежність було визнано у квітні 1992 р.). У період з січня по вересень 1992 р. 3 цими державами було встановлено дипломатичні відносини: 26 січня 3 Україною, Білоруссю, Казахстаном, Киргизстаном, Таджикистаном, Узбекистаном; 16 березня - з Молдовою; 22 квітня - 3 Туркменістаном; 3 серпня - з Грузією; 7 вересня - з Азербайджаном та Вірменією. 
У січні 1993 р. у найбільш населених країнах регіону - Україні (за сумісництвом було також розташоване Посольство Японії у Республіці Молдова), Білорусі, Казахстані, Узбекистані - було відкрито японські посольства. У квітні 1993 р. у Міністерстві закордонних справ Японії було засновано відділ Співдружності незалежних держав (там само, с. 4). У 2004 р. цей відділ реорганізовано у відділ Центральної Азії та Кавказу, а також відділ країн Південно-Східної Європи, до якого увійшла Україна (Гаймусьо сосікірей, 2000).

У політичному плані Японія приділяла особливу увагу країнам Центральної Азії. Перш за все, головний інтерес Японії у відносинах 3 цими країнами полягав в економічній сфері. 3 огляду на багаті родовища нафти й газу Каспійського моря Японія взяла курс на диверсифікацію джерел постачання енергоресурсів за рахунок країн Центральної Азії, що пояснюється іiї залежністю від імпорту ресурсів на 94 \% (Japan's Energy Supply Situation and Basic Policy, 2015). Розбудова відносин з центрально-азійськими республіками також вважалася необхідною для забезпечення балансу сил у контексті просування регіональних ініціатив Росією та Китаєм. Стабільність та демократичний розвиток цього регіону вважали елементом стабілізації Північної Азії в цілому.

3 огляду на вищезазначене, одразу після розпаду СРСР Японією було забезпечено активний політичний діалог із середньоазійськими республіками. У 1992 р. міністр закордонних справ Японії М. Ватанабе здійснив візит до Киргизстану та Казахстану. У 1993 р. до Японії було запрошено президента Киргизстану; у 1994 р. Японію відвідали президенти Казахстану та Узбекистану. У 1993 р. уряд Японії розпочав надавати центрально-азійським республікам фінансову допомогу.

У 1997 р. в Японії було прийнято зовнішньополітичну концепцію «Свразійська дипломатія», основною метою якої було проголошення стратегії стосовно Росії, Китаю та регіону «Шовкового шляху», що охоплює колишні радянські республіки Центральної Азії та Кавказу. Прем'єр-міністр Японії Р. Хасімото шукав можливості багатостороннього підходу до Євразійського континенту, підтримуючи тісні двосторонні відносини з США.

Наступним кроком стало створення у 2004 р. багатостороннього регіонального діалогу «Центральна Азія + Японія», метою якого є зміцнення співробітництва між Японією та країнами Центральної Азії, а також розширення діалогу між зазначеними республіками. Вважають, що одним із стимулів для інституалізації відносин Японії з Центральною Азією стало заснування у 2001 р. Шанхайської організації співробітництва, членами якої є Китай, Росія, Казахстан, Киргизстан, Таджикистан 
та Узбекистан. Значущість Центральної Азії для Японії відображено у розмірах допомоги: станом на 2014 р. регіону було надано понад 5 млрд. дол. США.

У 2015 р. С. Абе відвідав Монголію, Казахстан, Узбекистан, Таджикистан, Туркменістан та Киргизстан (останні три - вперше), що демонструє безпрецедентний рівень інтересу Японії. Під час зазначених візитів Абе заявив про надання допомоги Центральній Азії в сумі 24 млрд. дол. США (Удовік, 2016, с. 58-60).

\section{ський регіон»}

"Дуга свободи та процвітання" та форум «Японія - Чорномор-

Розширення дипломатії Японії на Захід не обмежилося впровадженням «Свразійської дипломатії» або «Дипломатії шовкового шляху», що включає Росію, Китай та країни Центральної Азії. Наступним етапом став розвиток відносин з Чорноморським регіоном та Східною Свропою, включно з Україною, які були об'єктом нової зовнішньополітичної ініціативи Японії «Дуга свободи та процвітання».

Поняття «Дуги свободи та процвітання» та «ціннісно-орієнтованої дипломатії» вперше було вжито в промові міністра закордонних справ Японії Т. Асо у 2006 р. На думку Асо, «ціннісно-орієнтована дипломатія» полягає в урахуванні таких «універсальних цінностей» як демократія, свобода, права людини, верховенство права та ринкова економіка в процесі здійснення зовнішньої політики. Міністр запропонував створити «Дугу свободи та процвітання» 3 молодих демократичних країн, розташованих у «зовнішньому колі Євразії», та проголосив цю ідею новим принципом зовнішньої політики Японії (Speech by Mr. Taro Aso, Minister for Foreign Affairs, 2006). До «Дуги свободи та процвітання» увійшли такі організації та країни як «КЛВ» (Камбоджа, Лаос та В’єтнам); Індія; Афганістан; країни Центральної Азії (Казахстан, Узбекистан, Киргизстан, Туркменістан, Таджикистан); Близький Схід; країни ГУАМ (Грузія, Україна, Азербайджан, Молдова); Співдружність демократичного вибору (Україна, Молдова, Латвія, Литва, Естонія, Словенія, Македонія, Румунія, Грузія); Вишеградська четвірка (Чехія, Угорщина, Польща, Словаччина) та Балтійські держави (Латвія, Литва та Естонія).

Важливість цієї ініціативи полягає в тому, що в зовнішньополітичній концепції Японії вперше йдеться про Чорне море, Україну, ГУАМ, а також Співдружність демократичного вибору (СДВ). У процесі розробки цієї концепції спочатку передбачалося, що вона буде стосуватися країн Чорноморського регіону, але згодом іiї дію було поширено на весь Свразійський континент (Муцусіка, 2017, с. 20-21). Проте, попри широкий географічний діапазон зазначеної концепції, Т. Асо окремо наголошував 
на необхідності забезпечення стабільності в країнах ГУАМ та приділяв важливу увагу зусиллям України, Грузії, Литви та Румунії у формуванні СДВ, яка, на думку міністра, «сприяє формуванню міцніших коренів демократії в Балтійсько-Чорноморському та Каспійському регіонах». Він також виступив за інтенсифікацію контактів між Японією та членами СДВ і ГУАМ, наголошуючи, що «краще продовжувати співпрацю з країнами, які здатні до партнерства з Японією» (Speech by Mr. Taro Aso, Minister for Foreign Affairs, 2006).

«Дуга свободи та процвітання» стала четвертим принципом зовнішньої політики Японії, доповнюючи принципи «міжнародного співробітництва через ООН», «співпраці з ліберальним світом» та «підтримки позиції як азійської нації», які було проголошено у 1957 р. Завдяки такій ініціативі Японія змогла не тільки зміцнити відносини з країнами, що розділяють 3 нею універсальні цінності, а й розширити свої дипломатичні горизонти шляхом інтенсифікації відносин з новими регіонами, зокрема з Чорноморським.

Багато японських спеціалістів високо оцінили впровадження ціннісно-орієнтованої дипломатії. На думку японського дипломата Н. Канехара та професора Осакського університету К. Сакамото, «Дуга свободи та процвітання» затвердила успіхи Японії в наданні допомоги країнам Східної Європи та Південно-Східної Азії з метою розвитку демократії та ринкової економіки. Зокрема, зазначається, що більшість східноєвропейських країн наразі належать до НАТО та ЄС як стабільні демократичні країни й бажають працювати разом з Японією, що можна вважати одним з прикладів успіху японської післявоєнної дипломатії (Канехара, \& Сакамото, 2007, с. 23).

Японський спеціаліст з дослідження країн Чорноморського регіону С. Муцусіка вважає проголошення «Дуги свободи та процвітання» «революцією в дипломатії» Японії. На його думку, ця концепція є кроком на шляху до глобалізації японської зовнішньої політики, яка зменшить відстань між цілями іiі дипломатії та відповідальністю за міжнародні справи. Він вважає, що «Дуга свободи та процвітання» підтвердила намір Японії відповідати за глобальну безпеку, що є відповідною позицією держави, яка прагне стати постійним членом Ради Безпеки ООН. Муцусіка також стверджує, що завдяки співробітництву з СС та НАТО в розбудові відносин з країнами Центральної Азії та Чорноморського регіону Японія буде мати більший простір для маневрування у стосунках 3 Росією та Китаєм (Муцусіка,2007, с. 2-4).

Посол Японії в Україні М. Мабучі (2005-2008 рр.) позитивно оцінив цю ініціативу, стверджуючи, що вона змінила місце України в 
зовнішній політиці Японії. На його думку, після проголошення «Дуги свободи та процвітання» Україна отримала шанс стати лідером Балтійсько-Чорноморсько-Каспійського регіону (Мабучі, 2009, с. 36).

Практичним відображенням «Дуги свободи та процвітання» стало заснування діалогу «ГУАМ + Японія». Підтримка Японією ГУАМу регіонального форуму, створеного у 1997 р. Україною, Азербайджаном, Грузією й Молдовою з метою просування демократії та ринкової економіки й організаційно оформленого у 2007 р. - було логічним продовженням демократичної хвилі, що охопила зовнішню політику Японії. У 2007 р. перша зустріч діалогу «ГУАМ + Японія» відбулася в Баку, а друга, присвячена річниці заснування ГУАМ, у Токіо за участі національних координаторів та генерального секретаря цієї організації, представників японського уряду, політичних і наукових кіл. У 2008 р. зустрічі в рамках «ГУАМ + Японія» було продовжено на саміті в Батумі та під час зустрічі Ради міністрів ОБСЄ в Гельсінкі. Четверту нараду представників ГУАМ та МЗС Японії було проведено в Токіо у 2009 р. В основному фокусі сторін були такі питання як енергетика, транспорт, захист навколишнього середовища, інвестиції, торгівля, а також мирне вирішення конфліктів відповідно до резолюцій Ради Безпеки ООН.

Після перемоги Демократичної партії Японії на виборах у 2009 р. в зовнішньополітичному курсі Японії спостерігалися певні концептуальні зміни. Прем'єр-міністр Ю. Хатояма запропонував концепцію «юай», в перекладі з японської «братська любов», яка пов'язується з ідеями Французької революції «liberté», «egalité» та «fraternité». Згідно 3 цією концепцією Хатояма позиціонував Японію як «міст» між Сходом і Заходом, між багатими й бідними країнами, а також між різними цивілізаціями. 3 огляду на пріоритетність азійського виміру зовнішньої політики Японії для уряду Хатояма, планувалося поліпшити відносини з Китаєм та створити Східноазійську співдружність (Stewart, 2009).

3 поверненням Ліберально-демократичної партії до влади у 2012 р. було відновлено акцент на демократичному напрямі зовнішньої політики Японії й посилено курс на підтримку демократичних організацій на кшталт ГУАМ. Прем’єр-міністр Японії С. Абе у своїй промові «Багатство відкритих морів: п'ять нових принципів японської дипломатії» у 2013 р. вказував на важливість «універсальних цінностей», наголошуючи на необхідності захисту свободи думки та слова (The Bounty of the Open Seas, 2013). Стратегія національної безпеки закріпила «підтримку та захист міжнародного порядку на основі універсальних цінностей» як одного з національних інтересів Японії (National Security Strategy, 2013). 
Такі події сприяли тому, що у 2013 р. та у 2015 р. в Токіо відбулися нові зустрічі форуму «ГУАМ + Японія», на яких сторони обмінялися думками з різних питань взаємної співпраці, зокрема, щодо управління водними ресурсами, енергетичної безпеки, туризму, міжнародних відносин. У 2015 р. було прийнято «Програму співпраці Японія - ГУАМ», в якій було окреслено основні цілі співпраці, серед яких консультації щодо «широкого кола актуальних проблем міжнародних та регіональних відносин з метою підтримання міжнародного миру та безпеки на основі Статуту ООН, загальновизнаних принципів та норм міжнародного права, зокрема, тих, що стосуються суверенітету й територіальної цілісності держав» (GUAM, 2018). Отже, до порядку денного «ГУАМ + Японія» було внесено питання окупації Криму Росією.

Співробітництво в рамках зазначеної структури також підтримується завдяки зустрічам на рівні міністрів закордонних справ, які мали місце у 2008 р., 2011 р., 2015-2019 pр. На додаток, проведено низку семінарів та воркшопів з таких напрямів як енергетична безпека; співпраця в медичній галузі; управління водними ресурсами; інвестиційне співробітництво; розвиток транспорту, туризму та сільського господарства.

«Дуга свободи та процвітання» мала важливе значення для розвитку відносин Японії з країнами Чорноморського регіону, адже саме завдяки цій ініціативі було заповнено географічні прогалини в зовнішньополітичній стратегії Японії. Підтримка Японією ГУАМ, що здійснюється шляхом впровадження «Дуги свободи та процвітання», надала більше впевненості країнам зазначеної організації в розвитку інститутів демократії. Запровадження Японією «ціннісно-орієнтованої дипломатії» також покращило відносини Японії з Україною та посилило позиції нашої держави на міжнародній арені.

Іншим важливим чинником, що сприяв поглибленню відносин Японії з ОЧЕС, стало заснування нового механізму міжнародного науково-політичного співробітництва - форуму «Японія - Чорноморський регіон». У 2005 р. в Токіо під егідою МЗС Японії, дослідницького інституту «Глобальний форум Японії» та однієї з провідних японських газет «Йоміурі сімбун» було проведено першу зустріч у рамках форуму на тему «Мир і процвітання в розширеному Чорноморському регіоні та роль Японії». Аналогічні зустрічі було проведено у 2007 р. («Японія та Чорноморський регіон у світі, що швидко змінюється»); 2010 р. («Перспективи змін у Чорноморському просторі та роль Японії») та 2013 р. («Як розвивати співпрацю Японії та Чорного моря»), на яких учасники обговорили «Дугу свободи та процвітання» й перспективи співробітництва Японії з країнами зазначеного регіону. 
3 української сторони у цих заходах брали участь посли України в Японії Ю. Костенко у 2005 р. та М. Кулинич у 2007 р. й 2010 р. Важливо зазначити, що на третій зустрічі форуму Кулинич виступив як основний доповідач з презентацією на тему «Вирішення проблем економічного розвитку в Чорноморському регіоні: бачення України». У 2013 р. співголовою форуму «Японія - Чорноморський регіон» був Посол України 3 особливих доручень М. Меленевський.

Японські дослідницькі кола в особі професорів С. Муцусіка (університет Сідзуока), Ю. Хасумі (університет Ріккьо), Й. Хіросе (університет Кейо) та інших експертів активно виступали за розвиток відносин Японії з Чорноморським регіоном, роблячи акцент на необхідності співпраці Японії з СС, Росією та США, важливості залучення нових гравців з метою послаблення залежності країн ОЧЕС від традиційних партнерів, а також досвіді, яким Японія може поділитися з причорноморськими країнами як азійська держава.

Виконуючи рекомендації, запропоновані під час вищезазначених форумів, у 2010 р. Японія стала партнером ОЧЕС по секторальному діалогу. Такий статус є гнучким і дозволяє діалогу не обмежуватися жодною конкретною сферою. Представники Японії можуть відвідувати засідання, спостерігати за обговоренням робочих груп в державах-членах ОЧЕС, а також брати участь у радах високого рівня на кшталт зустрічей міністрів закордонних справ.

Серед основних подій у співпраці Японії з ОЧЕС слід зазначити такі: у 2012 р. Генеральний секретар ОЧЕС В. Твіркун відвідав парламентського віце-міністра закордонних справ Японії К. Хамада в Токіо; у 2013 р. ОЧЕС та Японія провели в Стамбулі семінар із заходів щодо запобігання катастрофам в Японії, організований в рамках співпраці ОЧЕС та Японії як секторального партнера; у 2020 р. Генеральний секретар Постійного міжнародного секретаріату ОЧЕС М. Кристидес провів зустрічі з керівниками місій секторальних партнерів в Анкарі, включно з представником Японії.

Отже, аналіз вищезазначених подій дає підстави відзначити провідну роль, яку відіграло експертне середовище в інституалізації відносин Японії з ОЧЕС, та наголосити на важливості проведення таких заходів у майбутньому. Спільна робота політичної еліти з науковцями дозволяє дослідити увесь спектр співробітництва, а також налагодити безпосередні контакти між зацікавленими сторонами, що є особливо актуальним для багатосторонньої співпраці. У випадку Японії, запровадження «Дуги свободи та процвітання» на фоні розвитку науково-політичного діалогу стало прикладом успішної реалізації іiі зовнішньополітичних цілей. 


\section{Сучасний етап у відносинах Японії з Чорноморським регіоном}

Тимчасова окупація Кримського півострова РФ у 2014 р. відкрила новий етап співпраці Японії з Чорноморським регіоном та, зокрема, Україною. 18 березня 2014 р. міністр закордонних справ Японії Ф. Кісіда заявив, що референдум в українському Криму порушує конституцію України та не має юридичної сили, тому японський уряд не схвалить його результатів (Statement by the Minister for Foreign Affairs of Japan, 2014). 19 березня С. Абе сказав, що визнання Росією незалежності Криму та підписання договору про приєднання Криму до Росії порушують єдність, суверенітет і територіальну цілісність України. Він також наголосив на тому, що Японія не буде ігнорувати спроби змінити статус-кво за допомогою сили (Speeches and Statements by the Prime Minister, 2014).

До цих подій в Україні Японія під керівництвом прем'єр-міністра С. Абе була націлена на досягнення історичного прориву у відносинах 3 Росією. Проте криза в Україні та санкції щодо Росії з боку країн Групи Семи поставили під сумнів втілення курсу Японії на поліпшення японсько-російських відносин. Як активний гравець міжнародних відносин, який виступає за неухильне дотримання норм міжнародного права, Японія підтримала територіальну цілісність України та ввела санкції проти Pociï.

Перша хвиля санкцій проти Росії була проголошена Японією в березні 2014 р. Генеральний секретар Кабінету Міністрів Японії Й. Суга заявив, що Японія припинить переговори з Росією щодо скасування візових обмежень, інвестицій, використання космічного простору в мирних цілях, а також запобігання військової активності, що представляє загрозу. Протягом 2014 р. Японія припинила видачу віз для в'їзду російських громадян, які сприяли порушенню суверенітету й територіальної цілісності України; ввела санкції проти кримських компаній «Чорноморнафтогаз» i «Феодосія» та п'яти російських банків, а також посилила обмеження на експорт озброєнь до Росії. Надалі зазначені санкції було подовжено.

У червні 2015 р. відбувся візит прем'єр-міністра С. Абе до України. Це був перший візит очільника Японії до нашої держави. Під час переговорів з президентом П. Порошенком прем'єр-міністр Японії чітко заявив, що уряд Японії не потерпить ніяких спроб змінити статус-кво силою і що Японія підтримує принцип суверенітету й територіальної цілісності України. Прем'єр-міністр Японії наголосив на важливості дотримання Мінських домовленостей і пообіцяв відіграти активну роль у досягненні мирного врегулювання ситуації в Україні на саміті Групи Семи у 2016 р. в Японії. Під час візиту до України С. Абе оголосив про 
надання Українській державі фінансової допомоги в сумі 1,85 млрд. дол. США (Udovik, 2020, с. 77).

Згідно 3 досягнутими домовленостями під час візитів С. Абе до України у 2015 р. та П. Порошенка до Японії у 2016 р., Японія очолила обговорення ситуації в Україні під час головування на саміті Групи Семи на о. Iсе у префектурі Мie, що проходив у травні 2016 р. Учасниками саміту було прийнято декларацію, в якій вони засудили окупацію Криму та підтвердили курс на продовження міжнародних санкцій проти Росії. На прес-конференції прем'єр-міністр С. Абе говорив про проблеми світової економіки, а серед міжнародних конфліктів, перш за все, наголосив на українському питанні. Його основні тези включали необхідність дипломатичного врегулювання ситуації в Україні, важливість виконання Мінських угод та вимоги щодо конструктивної позиції Росії.

Слід зазначити, що Японія стала єдиною азійською державою, яка засудила дії Росії в Україні на офіційному рівні та ввела проти неї міжнародні санкції. Таку позицію Японії було чітко відображено в іiі підтримці України в ООН. Японія підтримала резолюцію Генеральної Асамблеї ООН про територіальну цілісність України від 27 березня 2014 р. (68/262), а також резолюцію щодо стану з правами людини в Автономній Республіці Крим та місті Севастополь (71/205) від 19 грудня 2016 р., в якій Росія визнається державою-окупантом, а Крим - тимчасово окупованою територією. Японія також виступила співавтором однойменних резолюцій ГА ООН від 19 грудня 2017 року (72/190) та 22 грудня 2018 року (73/263).

Під час ухвалення резолюції про територіальну цілісність України представник Японії в ООН М. Йосікава заявив, що «визнання РФ незалежності Автономної Республіки Крим разом з незаконною спробою анексувати Крим є посяганням на єдність, суверенітет і територіальну цілісність України» (Statement by H.E. Ambassador Motohide Yoshikawa, 2014). Японська точка зору полягає в тому, що дії Росії $є$ порушенням принципів Статуту ООН та серйозним викликом для всієї міжнародної спільноти.

Японія підтримала резолюції ГА ООН щодо «Проблеми мілітаризації Автономної Республіки Крим та міста Севастополь (Україна), а також частин Чорного й Азовського морів», прийняті 17 грудня 2018 р. (73/194) та 9 грудня 2019 р. (74/17), після захоплення українських кораблів Росією в Чорному морі 25 листопада 2018 р.

Вважається, що вагомою причиною підтримки Японією статус-кво та невизнання його змін силою є ситуація, що розгортається в регіоні островів Сенкаку (китайська назва - Дяоютай), розташованих у Схід- 
но-Китайському морі. Згідно з позицією Японії, ці острови було додано до іiї складу у 1895 р., а після Другої світової війни вони перейшли під контроль США згідно з Сан-Францискським мирним договором. Зазначається, що у 1972 р. США повернули острови Сенкаку Японії разом з Окінавою, а у 2012 р. японський уряд додатково придбав три острови цієї гряди.

Проте, така позиція не підтримується Китаєм, який у 2013 р. оголосив, що створить «Ідентифікаційну зону протиповітряної оборони Східного Китаю», включно з островами Сенкаку. У «білій книзі» 3 оборони Японії 2019 р. також зазначається, що «китайські урядові судна безперервно порушують японські територіальні води, а китайські військово-морські кораблі постійно оперують у водах навколо островів» (Defense of Japan, 2019, p. 44). Там йдеться і про те, що у 2016 р. бойове судно ВМС Китаю вперше зайшло в зону поблизу островів Сенкаку, а у 2018 р. такі дії здійснив китайський підводний човен (там само, с. 71-72).

На думку експерта Інституту Міцуі Д. Кітаде, нелегальна окупація Кримського півострова Росією створює «небезпечний прецедент», який може мати глобальні наслідки та негативний вплив на безпеку самої Японії. Можливість відтворення такого сценарію в регіоні навколо Китаю спонукає Токіо домагатися засудження дій РФ міжнародною спільнотою. Д. Кітаде також зазначає, що через активізацію діяльності Китаю у Східно-Китайському морі, разом зі спробами обмежити повітряний рух навколо зазначених островів, Японія наголошує на важливості впровадження політики «відкритих та стабільних морів» (Kitade, 2020).

Деякі експерти, зокрема професор університету Ніігата С. Хакамада вказують на «дилему», що постала в зовнішній політиці Японії у зв'язку з необхідністю синхронізації дій з США щодо санкцій проти Росії через окупацію нею Криму з намаганням покращити японсько-російські відносини (Mizuho, 2014). Офіційна позиція японського уряду 3 цього питання була висловлена Послом Японії в Україні Ш. Сумі (20142019 рр.), який зазначив, що позиція Японії полягає в тому, що дії Росії проти України, питання Криму та Донбасу, мають бути відокремлені від перемовин щодо повернення Північних територій. Він стверджує, що Японія не визнає й надалі не визнаватиме «анексії» Криму та продовжуватиме антиросійські санкції доти, поки триватиме незаконна анексія Криму Росією (Хірано, 2018). Підтримку Японією територіальної цілісності та суверенітету України було підтверджено під час зустрічі президента України В. Зеленського з прем'єр-міністром Японії С. Абе, яка відбувалася в рамках візиту президента України до Японії у 2019 р. з метою участі в церемонії інтронізації Імператора. 
Посол Т. Кураі (з 2019 р.), зі свого боку зазначив, що ключовим елементом у контексті вирішення територіальних питань $є$ збереження солідарності міжнародної спільноти (Сірук, 2019). Тому подальша співпраця України та Японії в цьому напрямі є важливим елементом для досягнення деокупації Криму та повернення його до складу України.

Результати співпраці Японії з краӥнами Чорноморського регіону

Результати співробітництва Японії з країнами Чорноморського регіону можна простежити за декількома напрямами. Перш за все, після розпаду Радянського Союзу Японія почала надавати підтримку пострадянським країнам, спрямовану на їх стабілізацію, демократизацію та перехід до ринкової економіки. Загалом Японія надала 3 млрд. дол. США, включно з технічною допомогою на кшталт прийняття та направлення експертів до країн колишнього СРСР, невідкладною гуманітарною допомогою, а також наданням кредитів 3 метою сприяння торговельній та економічній діяльності. Також Японія взяла участь у багатосторонніх заходах з надання допомоги колишньому СРСР. У 1992 р. уряд Японії провів Конференцію з питань допомоги новим незалежним державам у Токіо; надав 20 млн. дол. США Міжнародному науково-технічному центру, основною метою якого є сприяння співпраці з вченими нових незалежних держав колишнього СРСР; сприяв формуванню пакету підтримки у 24 млрд. дол. США та переплануванню боргів. Крім того, Японія активно підтримувала зусилля з реформування країн Центральної та Східної Європи після падіння Берлінської стіни в 1989 р. Допомога Японії цьому регіону сягала 4,5 млрд. дол. США (Objectives and Priorities of Japan's Foreign Policy, 1992).

На сучасному етапі увагу Японії зосереджено на наданні підтримки з метою забезпечення розвитку демократичних інститутів та ринкової економіки в причорноморських країнах на основі «Дуги свободи та процвітання». Зокрема, Японія спрямовує свої зусилля на підтримку України та Молдови, стабільний розвиток яких є необхідним елементом для забезпечення стабільності Чорноморського регіону.

32014 р. Японія неухильно реалізує допомогу Україні в розмірі 1,85 млрд. дол. США, що є однією з найбільших сум, наданих на двосторонній основі. У рамках підтримки демократії в Україні Японією проведено семінар з обміну знаннями та досвідом з метою надання допомоги в питаннях демократизації України (2015 р.); надано позику для розвитку економічних реформ, спрямованих на відновлення фінансової системи та проведення інституційних реформ (2015-2016 рр.); розпочато проект розвитку суспільного мовлення України (2017р.). Через міжнародні 
організації надається допомога для покращення рівня життя внутрішньо переміщених осіб та відбудови інфраструктури Сходу України.

Що стосується Кавказу, до якого належать Азербайджан, Вірменія та Грузія, у 2018 р. уряд Японії розпочав впровадження «Кавказької ініціативи», яка складається 3 таких напрямів як «допомога розвитку людських ресурсів для державного будівництва», що полягає в реалізації навчальних програм для усталеного розвитку, та «допомога в прокладанні шляху до привабливого Кавказу», яка має на меті розвиток інфраструктури та підтримку бізнес-середовища.

У тому ж році С. Абе заявив про сприяння економічним і соціальним реформам у регіоні Західних Балкан, включно з такими членами ОЧЕС, як Албанія та Сербія, що реалізовуватиметься в рамках «Ініціативи співробітництва з Західними Балканами».

Розвиток інфраструктурних та екологічних проектів, а також економічних зв'язків 3 партнерами Чорноморського регіону є іншим важливим напрямом зовнішньої політики Японії. Допомога надається через Японське агентство міжнародного співробітництва (Japan International Cooperation Agency) у формі Офіційної допомоги розвитку - урядової допомоги Японії, покликаної сприяти економічному розвитку та добробуту країн, що розвиваються.

Основні проекти японської ОДР в країнах ОЧЕС передбачають удосконалення автомобільних доріг у Грузії, модернізацію порту Бургас й розширення метро в Софії (Болгарія), будівництво залізничного тунелю під протокою Босфор у Туреччині, забезпечення залізничного доступу до міжнародного аеропорту Бухареста в Румунії, вдосконалення системи каналізації Тирани в Албанії, встановлення установок для десульфурації димових газів на теплових електростанціях у Сербії, проект розвитку міжнародного аеропорту «Бориспіль» та модернізація аераційної станції «Бортничі» в Києві. Найбільшими одержувачами ОДР Японії в Чорноморському регіоні, включно 3 позиками, грантовою та технічною допомогою, станом на кінець 2018 р. були Туреччина (7 млрд. 502 млн. дол. США); Україна (1 млрд. 846 млн. дол. США); Азербайджан (1 млрд. 149 млн. дол. США); Сербія (672 млн. дол. США); Вірменія (438 млн. дол. США) та Грузія (412 млн. дол. США) (Official Development Assistance, 2018).

Окрім цього, Японія зробила вагомий внесок у розвиток енергетичних проектів Чорноморсько-Каспійського регіону, таких, як освоєння низки найбільших морських родовищ нафти та природного газу в Каспійському морі, будівництво нафтопроводу Баку - Тбілісі - Джейхан та газопроводу для транспортування природного газу з Азербайджану до Туреччини через Грузію. 
Найбільшими торговельними партнерами Японії серед країн ОЧЕС станом на кінець 2019 р. є Росія (23 млрд. 432 млн. дол. США); Туреччина (3 млрд. 578 млн. дол. США); Румунія (1 млрд. 480 млн. дол. США); Україна (1 млрд. 373 млн. дол. США); Греція (1 млрд. 208 млн. дол. США ) та Грузія (391 млн. дол. США) (Trade Statistics of Japan, 2020). Подальшій активізації торговельних відносин 3 країнами регіону сприятиме підписання угод про економічне партнерство (наразі таку угоду укладено між Японією та ЄС, ведуться переговори Японії з Туреччиною).

У сфері міжнародного миру та безпеки Японія традиційно висловлює свою позицію щодо подій у країнах Чорноморського регіону шляхом політичних заяв, аналізу поточної ситуації в щорічній «блакитній книзі» 3 дипломатії та «білій книзі» з оборони Японії, а також завдяки співпраці в рамках міжнародних організацій. Окрім кримського питання, Японія зайняла чітку позицію щодо підтримки територіальної цілісності Грузії після визнання Росією незалежності Абхазії та Південної Осетії у 2008 р., виступила за мирне врегулювання конфлікту в Нагірному Карабасі на основі принципу суверенітету та територіальної цілісності Азербайджану, заявила про невизнання виборів у так званих «ЛНР» та «ДНР» в Україні у 2018 р., а також підтримала резолюцію ГА ООН щодо російських військ у Придністров”і, Молдові «Про повне і беззастережне виведення іноземних збройних сил з території Республіки Молдова» (А/72/L.58) у 2018 р. Разом з тим, у 2008 р. Японія визнала незалежність Косово.

3 2010-х рр. Японія почала розвивати двостороннє співробітництво з членами ОЧЕС у безпековій галузі. У 2013 р. віце-міністр оборони Японії М. Сато відвідав Азербайджан, у 2015 р. державний міністр оборони Японії М. Сато здійснив візит до Болгарії, а у 2017 р. віце-міністр оборони Японії з питань міжнародних відносин Р. Манабе відвідав Україну. У 2013 р. міністр оборони Японії І. Онодера зустрівся 3 міністром національної оборони Туреччини I. Сльмазом у Токіо з метою обговорення оборонного співробітництва відповідно до «Заяви про наміри між Міністерством оборони Японії та Міністерством національної оборони Турецької Республіки» від 2011 р. У 2015 р. міністр оборони Г. Накатані зустрівся зі своїм колегою з Грузії Т. Хідашелі в Токіо.

Японія також заснувала двосторонні безпекові консультації з двома державами Чорноморського регіону - Україною та Росією. Консультації 3 Росією у форматі «2+2» за участі представників міністерств закордонних справ та оборони було розпочато у 2013 р. Після окупації Криму такі консультації було припинено, але відновились у 2017 р., потім відбулися у 2018 р. та 2019 p. 
У 2018 р. вперше було проведено українсько-японські консультації 3 питань безпеки у форматі «2+2», в результаті яких сторони підписали Меморандум про співробітництво та обміни в оборонному секторі. Співпрацю з питань безпеки між Японією та Україною було посилено завдяки зустрічі між міністром оборони України А. Загороднюком та міністром оборони Японії Т. Коно під час Мюнхенської конференції 3 безпеки, яка відбулася в лютому 2020 р. Японія також планувала вперше взяти участь у навчанні «Сі-Бріз 2020», але через поширення коронавірусу плани було скасовано. На додаток, станом на 2018 р., Японія підтримує діалог з кібербезпеки з 11-ма країнами світу, дві з яких - Україна та Росія - належать до Чорноморського регіону.

Культурно-гуманітарний вимір співпраці розвивається завдяки організації культурних заходів, зокрема, «Року Японії», який було проведено в Греції (1999р.); Румунії (2002 р.); Туреччині (2010р.); Україні (2017 р.) та Росії (2018р.). Здійснено візити членів Імператорської родини Японії до Болгарії, Греції, Туреччини, Росії, Румунії; подальшої актуальності набуває організація такого візиту до України. Японським урядом надаються культурні гранти та стипендії для навчання в Японії. Міжлюдські обміни відбуваються завдяки встановленню безвізового режиму ( $\mathrm{CC}$, Сербія, Туреччина) та спрощенню візових вимог для короткострокового відвідання Японії (Україна, Грузія, Росія). Подальші перспективи співпраці пов'язують 3 проведенням Олімпійських ігор у Токіо у $2021 \mathrm{p}$.

В умовах всесвітньої пандемії Covid-19 японський уряд прийняв рішення щодо безоплатної передачі медичного препарату «Авіган», який може бути ефективним у лікуванні зазначеного коронавірусу, низці країн, серед яких є і причорноморські держави, а саме: Україна, Албанія, Болгарія, Грузія, Молдова, Сербія та Туреччина.

\section{Висновки}

Таким чином, можемо стверджувати, що розбудова відносин Японії з причорноморськими країнами відбувалася в контексті загального розширення дипломатії Японії, у тому числі завдяки ії перетворенню на «нормальну країну», яка робить активний внесок у підтримання міжнародного миру та безпеки, а також з урахуванням відносин Японії з Свропейським Союзом та пострадянськими країнами. На концептуальному рівні стратегію Японії щодо Чорноморського регіону та України було оформлено в середині 2000-х рр. завдяки введенню ініціативи «Дуга свободи та процвітання» як четвертого принципу зовнішньої політики Японії, яку можна вважати логічним продовженням «Дипломатії шовкового шляху». Важливу роль у цьому контексті відіграли японські екс- 
пертні кола, які активно пропагували ідею більш тісної співпраці Японії з ОЧЕС у рамках форуму «Японія - Чорноморський регіон». Саме завдяки цьому у 2010 р. Японія набула статусу секторального партнера зазначеної організації, що перевело співпрацю з країнами регіону з двостороннього на багатосторонній рівень. Окупація Кримського півострова РФ відкрила новий етап у відносинах Японії з Чорноморським регіоном, а незмінна позиція Японії з підтримки суверенітету та територіальної цілісності України, яка базується на універсальних цінностях та концепції С. Абе щодо «активного пацифізму», підтвердила іiі статус глобальної держави.

Наразі існують позитивні перспективи щодо подальшого розвитку співробітництва між Японією та Чорноморським регіоном. За винятком територіальної суперечки з Росією, Японія має дружні стосунки з членами ОЧЕС, що закладає міцну основу для їх подальшого розвитку в майбутньому. Японія працює разом з причорноморськими країнами як на двосторонньому, так і на регіональному й міжнародному рівнях за такими напрямами, як підтримка демократії, економічне співробітництво, покращення інфраструктури й навколишнього середовища, забезпечення міжнародного миру та людської безпеки, зміцнення культурних $\mathrm{i}$ міжсуспільних зв'язків. Досвід Японії як активного члена ООН та Групи Семи, одного з лідерів Азійсько-Тихоокеанського регіону, третьої світової економіки, технологічно розвиненої країни й одного з найбільших міжнародних донорів надає широкі можливості для стабілізації регіону та покращення добробуту його народів.

3 іншого боку, участь Японії в міжнародних процесах, що відбуваються в Чорноморському регіоні, дозволила їй розширити свої дипломатичні горизонти. Запровадження «Дуги свободи та процвітання» і прийняття Стратегії національної безпеки стало важливою подією у затвердженні ціннісно-орієнтованої дипломатії як принципу зовнішньої політики Японії, що забезпечило їі цілісність та безперервність у регіоні від Центральної Азії до Чорного моря, Балкан та Східної Європи. Така стратегія надає Японії можливість краще розуміти динаміку регіональних процесів з урахуванням діяльності таких гравців, як Росія й Китай, та більш ефективно просувати свої національні інтереси на міжнародній арені; підтверджує іiї провідну роль у налагодженні співпраці між Азією та Європою, а також обгрунтовує позицію Японії щодо набуття постійного членства в Раді Безпеки ООН.

Одним із глобальних партнерів Японії в Чорноморському регіоні є Україна - держава, яка поділяє з Японією універсальні демократичні цінності й підходи до міжнародних відносин. Двосторонні зв'язки між 
зазначеними країнами базуються на спільних інтересах у регіоні, як сприяння розвитку демократії й ринкової економіки, а також забезпечення миру та безпеки. Підтримка Японією України в умовах окупації іiі територій РФ, збільшення обсягів фінансової допомоги нашій державі, а також рішення вперше взяти участь у військово-морських навчаннях у Чорному морі відповідають принципу «активного внеску в забезпечення миру» та підтверджують статус Японії як активного гравця міжнародних відносин. Подальше посилення синергії між Україною та Японією шляхом співробітництва в рамках ОЧЕС, «Японія + ГУАМ» та ОБСЄ, приєднання України до АCEM, а також підтримка Японією Східного партнерства сприятиме досягненню спільної мети й покращить координацію дій між всіма зацікавленими сторонами в Чорноморському регіоні. Посилення українсько-японського тандему надасть також подальший імпульс для розвитку співпраці між Причорномор'ям та Азією.

\section{Список посилань}

1. Гаймусьо сосікірей (Наказ щодо структури Міністерства закордонних справ). Денсі сейфу но сого мадогуті (Портал електронного уряду) (2000). Взято з https://elaws.e-gov.go.jp/ (японською мовою).

2. Мабучі, М. (2009). Ніхон кокка но «кататі» о мотомете - ніхон гайко «сайсей» е но тейген (У пошуках «форми» Японської держави - пропозиції щодо «відродження» японської дипломатії). Дипломатичний форум, 5, 36-42 (японською мовою).

3. Муцусіка, С. (2007). Сейсаку тейген: коккай кьорьоку ніхон но тай коккай сейсаку - «Дзію то хан'ей но ко» гайко о мотомете (Політичні рекомендації: чорноморське співробітництво. Політика Японії у Чорноморському регіоні - у пошуках дипломатії «Дуги свободи та процвітання»). Взято 3 http://www2.jiia.or.jp (японською мовою).

4. Муцусіка, С. (2017). Коккай тіікі но кокусай канкей (Міжнародні відносини Чорноморського регіону). Нагоя: Нагоя дайгаку сюппан (японською мовою).

5. Сакамото, К. \& Канехара, Н. (2007). «Уцукусій куні» но «сюттьо суру гайко» га медзасу моно - сімінкен кайфуку гайко но дзідай ва оватта (Мета дипломатії «красивої країни» - кінець епохи відновлення прав в якості члена міжнародної спільноти). Дипломатичний форум, 4, 18-27 (японською мовою).

6. Сірук, М. (2019). Дві мети Посла. Такаші Кураі: «Японія хоче й надалі бути дуже добрим другом і партнером України». День. Взято з https://day. kyiv.ua/

7. Удовік, В. (2016). Зовнішня політика Японії на пострадянському просторі (1991-2016 рр.). Схід: аналітично-інформачійний журнал, 5 (145), 56-63.

8. Уяма, Т., Лен, К., \& Хіросе, Т. (2009). Ніхон но тюо адзіа гайко - тамесареру тіікі сенряку (Центральноазійська дипломатія Японії: випробування регіональної стратегіï). Токіо: Хоккайдо дайгаку сюппан (японською мовою). 
9. Хірано, Т. (2018). Шігекі Сумі, Посол Японії в Україні: Збереження Японією санкцій проти Росії - питання принципу не лише для Криму й Донбасу. Укрінформ. Взято з https://www.ukrinform.ua/rubric-world/2606025sigeki-sumi-posol-aponii-v-ukraini.html

10. Defense of Japan (2019). Ministry of Defense. Retrived from https://www. mod.go.jp/e/publ/w_paper/wp2019/pdf/DOJ2019_Full.pdf

11. GUAM-Japan Cooperation Program (2015). GUA $M$. Retrieved from https:// guam-organization.org/en/guam-japan-cooperation-program/

12. Iwanaga, K. (2011). Japan's Paradigm Lost? In B. Edström (Ed.), Japan's Foreign Policy in Transition: The Way Forward for Japan as an International Actor in a World in Flux, 58-72. Singapore: Institute for Security and Development Policy. Retrieved from https://www.isdp.eu/content/uploads/images/ stories/isdp-main-pdf/2011_edstrom_japans-foreign-policy.pdf

13. Japan's Energy Supply Situation and Basic Policy (2015). The Federation of Electric Power Companies in Japan. Retrieved from https://www.fepc.or.jp/ english/energy_electricity/supply_situation/

14. Kitade, D. (2020). The Butterfly Effect: Why Does Eastern Europe Matter to Japan? Retrieved from https://www.iss.europa.eu/content/butterfly-effect-why-does-eastern-europe-matter-japan

15. Market Intelligence (2018). World Tourism Organization. Retrieved from https://www.unwto.org/es/market-intelligence

16. Mizuho, A. (2014). Ukraine crisis has Japan on horns of a dilemma. Stance against territory violations endangers closer ties with Russia. Retrieved from https://www.japantimes.co.jp

17. National Security Strategy (2013). Cabinet Secretariat. Retrieved from https:// www.cas.go.jp/jp/siryou/131217anzenhoshou/nss-e.pdf

18. Objectives and Priorities of Japan's Foreign Policy. Section 2 (1992). Ministry of Foreign Affairs of Japan. Diplomatic Bluebook. Retrieved from https:// www.mofa.go.jp/policy/other/bluebook/1992/1992-1-2.htm

19. Official Development Assistance (ODA) (2018). Ministry of Foreign Affairs of Japan. Retrieved from https://www.mofa.go.jp/policy/oda/data/index.html

20. Soeya, Y., Welch, D., \& Tadokoro, M. (2011). Japan as a «Normal Country»?: A Nation in Search of Its Place in the World. Toronto: University of Toronto Press.

21. Speech by Mr. Taro Aso, Minister for Foreign Affairs on the Occasion of the Japan Institute of International Affairs Seminar "Arc of Freedom and Prosperity: Japan's Expanding Diplomatic Horizons" (2006). Ministry of Foreign Affairs of Japan. Retrieved from http://www.mofa.go.jp/announce/fm/aso/ speech0611.html

22. Speeches and Statements by the Prime Minister (2014). Prime Minister of Japan and His Cabinet. Retrieved from https://japan.kantei.go.jp/96_abe/statement/201403/0320kaiken.html

23. Statement by H.E. Ambassador Motohide Yoshikawa Permanent Representative of Japan to the United Nations at the Debate on the Situation in Ukraine (2014). Permanent Mission of Japan to the United Nations. Retrieved from http://www.un.emb-japan.go.jp/statements/yoshikawa032714.html

24. Statement by the Minister for Foreign Affairs of Japan on the Measures 
against Russia over the Crimea referendum (2014). Ministry of Foreign Affairs of Japan. Retrieved from https://www.mofa.go.jp/mofaj/press/danwa/ page4_000409.html

25. Stewart, D. T. (2009). How Japan's New Leader May Redefine the Nation. Newsweek. Retrieved from https://www.newsweek.com/how-japans-newleader-may-redefine-nation-80995

26. The Bounty of the Open Seas: Five New Principles for Japanese Diplomacy (2013). Ministry of Foreign Affairs of Japan. Retrieved from https://www. mofa.go.jp/announce/pm/abe/abe_0118e.html

27. Trade Statistics of Japan (2020). Japan Customs. Retrieved from https://www. customs.go.jp

28. Udovik, V. (2020). The Black Sea Area in Japan's Expanding Strategic Horizons. Ukraine Analytica, 1 (19), 72-79. Retrieved from http://ukraine-analytica.org/wp-content/uploads/Udovik.pdf 


\section{ВИСНОВКИ}

$\Longrightarrow$ 

Міжнародна торгівля, міграційні потоки та боротьба за стратегічний контроль над регіоном є чинниками, що визначають важливість Чорноморського регіону. У ЧР сьогодні перетинаються інтереси та шляхи великих та малих акторів.

$\epsilon C$, зокрема, став однією з ключових сил, яка впливає на трансформацію регіону. ЄС є найбільшим торгівельним та інвестиційним партнером для усіх країн ЧР. Потенціал ЧР у сфері транспортно-транзитної та енергетичної комунікації є важливою складовою європейської економіки. Увага з боку СС до регіону пов'язана з наявністю чинників, що негативно впливають на загальноєвропейську безпеку (конфлікти, економічні кризи, політична нестабільність, організована злочинність). 3 інтеграцією Болгарії та Румунії Свросоюз мав стати одним з найвагоміших акторів ЧР, а країни Балтійського регіону, Греція та Польща особливо були зацікавлені в посиленні ролі ЄС у регіоні. Однак, незважаючи на наявні інтереси та існуючі важелі, СС помилився як у готовності країн регіону об'єднати зусилля для розвитку ЧР, так і у впливі європейських ініціатив на реформування країн регіону. Але найсерйознішою проблемою стала неузгодженість позицій всередині самого Союзу щодо важливості регіону для Європи. У майбутньому це загрожує перетворити ЄС на другорядного актора в регіоні, який втратить важелі впливу на регіональні процеси та буде діяти лише в межах гуманітарних проектів. До прийняття Стратегічної Концепції НАTO 2010 р. Альянс не вбачав у Чорномор'ї регіон, який потребував комплексного підходу. Незважаючи на те, що три прибережні держави є його членами, НАТО не визначав себе частиною регіону. Лише у 2014 р. спостерігався тимчасовий зсув у збільшенні інтересу НАТО до Чорного моря. Отже, сьогодні Альянс потребує чіткішого формулювання майбутньої чорноморської стратегії, визначення ризиків та загроз і застосування всього свого потенціалу щодо управління кризами. Важливість такої реакції обумовлена поведінкою інших акторів, у першу чергу РФ.

Росія після анексії Криму перетворила півострів на фортецю російської влади, що проектується в регіоні. Анексія Криму зробила Чорноморський флот стратегічно важливим об'єктом. Серед регіонів майбутньої відповідальності ЧФ РФ бачить Червоне море, Перську затоку, навіть Аравійське море. У майбутньому це може стати причиною для застосування ядерної зброї з метою деескалації, якщо російське звичайне стримування не буде достатньо ефективним, щоб утримати Захід від безпосереднього військового втручання. Потенціал озброєння російського Чорноморського флоту зростає; Росія продовжує використовувати Чорне море для розширення свого впливу на сусідні регіони, вклю- 
чаючи Балкани, Близький Схід та середземноморські країни. У Середземномор'ї Росія визначає багато загроз для своєї безпеки й впливу на сирійський конфлікт. Росія маніпулює загрозою відмови (або суттєвого обмеження) військових навчань НАТО в регіоні, що означає поступове перетворення Чорного моря на «Російське озеро».

Наявність низки спільних турецько-російських проектів у стратегічних сферах оборонної промисловості, ядерної енергетики та ВПК відіграє важливу роль у продовженні балансування Туреччини між РФ і Заходом. 3 іншого боку, рівень довіри між Анкарою та Москвою є досить низьким. Нарощування військової сили РФ не відповідає інтересам Анкари, тому Туреччина в майбутньому приділятиме більшу увагу розвитку тісного співробітництва з Україною та Грузією, а також іншими малими країнами ЧР.

«Прагматичне балансування» $є$ наріжним каменем регіональної політики не тільки Туреччини, а й так званих «третіх сил»-Японії та Китаю. Взаємодія з ними не є загрозою для російської політики, наприклад, у Вірменії, але забезпечує Сревану певний простір для маневру й сильнішу позицію у двосторонніх переговорах з Кремлем. Зростання обсягу експорту озброєнь із Росії до Азербайджану та збройні дії у Нагірному Карабасі у 2016 та 2020 рр. змушують Вірменію диверсифікувати свою майбутню політику. Оскільки відносини з Туреччиною $є$ холодними, майже єдиним серйозним позасистемним гравцем, 3 яким може взаємодіяти Вірменія, є Китай. Грузії також вдалося побудувати тісне стратегічне партнерство з Китаєм. Залучаючи інвестиції, скасовуючи візи й прагнучи налагодити тісніші зв'язки з позасистемними державами, Грузія намагається компенсувати напруженість у відносинах 3 Росією. Тбілісі сприймає китайські інвестиції як додатковий захист від політики Росії в регіоні. Молдова та Азербайджан наразі мають найменш розвинені відносини з «третіми силами», але їх потенціал не слід недооцінювати. Політично агресивна, але економічно слабка Росія змусила країни Чорномор'я прагнути до зміцнення впливу Китаю в регіоні. Розвиток економічних зв'язків з КНР дозволить захиститися від надмірного впливу сильних сусідів, але потенційно може підірвати взаємодію з СС, якщо Китай продовжуватиме надавати позики та гранти, вільні від політичних умов і критеріїв. Хоча проект «Один пояс, один шлях» описується винятково в економічному дискурсі, в разі імплементації така ініціатива, ймовірно, зміцнить політичний вплив Китаю й може змінити баланс сил у Чорноморському регіоні.

Відносини України з Китаєм орієнтовані переважно на торгівлю й економіку, особливо у військово-технічній та сільськогосподарській 
сферах. Партнерство Києва 3 «третіми силами» слугує досягненню декількох цілей: доступ до нових ринків, залучення нових інвестицій, диверсифікація джерел енергоресурсів, забезпечення підтримки в невизнанні анексії Криму, поваги до прав кримських татар і відновлення територіальної цілісності України. I хоча українська дипломатія залишається орієнтованою переважно на взаємодію з СС та США, Україна прагне розвивати відносини з «третіми силами» для посилення власної стійкості до політики Росії. В цілому політика України в ЧР - це не стільки історія пошуку шляхів ефективної моделі міжрегіонального економічного співробітництва, скільки історія тактичних перемог і стратегічних помилок, історія нереалізованих можливостей. Для реалізації чорноморського вектора зовнішньої політики України перед iï політичним керівництвом стоїть вкрай важливе завдання: провести «роботу над помилками» і зробити висновки про невикористані раніше можливості. Розробка довгострокової стратегії повернення Кримського півострова до суверенітету України неможлива без урахування кількох ключових чинників, що впливатимуть на політику держави. По-перше, сучасні енергетичні стратегії формуватимуть нову геоекономічну регіональну просторову реальність - Чорноморсько-Каспійський регіон. Не тільки регіональні актори, а й позарегіональні, включаючи енергетичні ТНК, що давно присутні на ринку вуглеводнів у басейні Чорного й Каспійського морів, готові жорстко відстоювати свої інтереси. Питання чорноморської безпеки стосується не тільки військового компоненту, а й економічної безпеки, виклик якій кидає зростаюча глобальна конкуренція та протекціонізм. По-друге, ЧР можна віднести до одного 3 найбільш небезпечних регіонів світу з високим рівнем конфліктогенності; він усе частіше асоціюється з початком нової «холодної війни». Як наслідок, Чорноморський регіон автоматично стає робочою студією для «обкатки» нових безпекових моделей, що діятимуть у середньостроковій перспективі. Наслідком перетворення Росією Кримського півострова на військову фортецю є відповідні ініціативи з боку НАТО розмістити елементи ПРО в Румунії та Туреччині. Україна, як і весь регіон, стає потенційною заручницею цієї ситуації. По-третє, геополітична конкуренція переходить у площину ціннісних зіткнень різноманітних культур. Проникнення до ЧР демократичних традицій накладається на відсутність історичного досвіду реалізації демократичних цінностей, тому що чорноморські держави переживають драматичний процес ментального перелому або навіть злому. Це ускладнює процес прийняття зовнішньополітичних рішень держав, особливо з такими обмеженими ресурсами, як Україна. 
Дослідження політики головних акторів регіональних відносин дозволило дійти висновку, що поняття «Чорноморський регіон» поступово набуває суто географічного сенсу. Для країн ЧР у сенсі економічного, політичного та ідеологічного розвитку більше значення має приналежність до підсистем (таких як РПК, НСЄ, ЦСЄ та ПСЄ), аніж до більшої системи ЧР. Мало знайдеться регіонів світу із такими внутрішніми протиріччями. Пояснення можна знайти у площині зростаючої небезпеки у відносинах країн-сусідів із різними, а місцями й протилежними національними інтересами - РФ та України, РФ та Туреччини, РФ та Молдови, РФ та Грузії, Туреччини та Греції, Азербайджану та Вірменії. Множинність вузлів протиріч у ЧР негативно впливає на всіх акторів, але насамперед на малі країни регіону, які слід визначати не за площею країни, а за економічними та політичними ресурсами. Голос малих країн не чути у Чорномор'ї; до них слід віднести й Україну. Отже, дисфункція ЧР об'єктивно впливає на загальну дисфункцію української зовнішньої політики, що $€$ величезною проблемою, адже саме ЧР було визначено як головний майданчик, де наша країна мала на меті створити альянс малих держав заради успішного спільного захисту своїх інтересів. Наразі цей шанс можна вважати майже втраченим.

У перспективі розвиток регіону визначатимуть два регіональних лідери - Туреччина та Росія, які будуть тим більш успішними у захисті власних інтересів, чим менш узгодженою буде політика ЄС та НАТО. При цьому якщо РФ переважно використовує інструменти жорсткої сили, то ТР стає регіональним лідером у всіх сферах суспільно-політичного життя, спираючись як на джерела внутрішнього росту, так і на успішну кооперацію 3 позасистемними акторами, найбільшим з яких $\epsilon$ КНР. Саме сценарій співпраці Туреччини та Китаю в регіоні $є$ найбільш вірогідним та найбільш прийнятним для більшості чорноморських акторів. 


\section{АВТОРСЬКИЙ КОЛЕКТИВ}

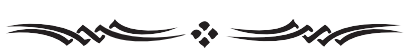



БРУСИЛОВСЬКА Ольга Іллівна, професор (2012), доктор політичних наук (2008). Працює в ОНУ імені I. I. Мечникова з 1991 р. Зав. кафедри міжнародних відносин з 2015 р. Захистила дисертацію зі спеціальності 23.00.04 - політичні проблеми міжнародних систем та глобального розвитку в ICEМВ НАНУ на тему «Політико-системні трансформації в регіоні Східна Європа. 1989-2004». С автором більше 80 наукових праць, у тому числі монографії «Посткомуністична Східна Свропа: зовнішні впливи, внутрішні зміни» (2008); перероблене та доповнене перевидання «Systemic Transformation of the Region Eastern Europe (1989-2004)» (2016). Член редколегії наукових журналів «Міжнародні та політичні дослідження» (Одеса, Україна); «Політичне життя» (Вінниця, Україна), «Політологічний вісник» (Київ, Україна), «Трансформації» (Варшава, Польща), електронний науковий журнал «Риторика та комунікації» (Софія, Болгарія); член рецензійної колегії наукового журналу «Стратегічний вісник» (Познань, Польща).

Електронна адреса: brusylovska@onu.edu.ua

ГАБЕР Свгенія Василівна, кандидат політичних наук (2014), заступник директора Дипломатичної академії ім. Г. Удовенка при МЗС України з 2018 р. У 2009-2014 рр. працювала на кафедрі міжнародних відносин ОНУ імені I. І. Мечникова, у 2014-2018 pp. - другим секретарем Посольства України в Турецькій Республіці. Захистила дисертацію зі спеціальності 23.00.04 - політичні проблеми міжнародних систем та глобального розвитку в IMB КНУ імені Тараса Шевченка на тему «Регіональний вимір турецько-американських відносин в пост-біполярний період». С автором понад 40 наукових праць та співавтором декількох колективних монографій з питань зовнішньої політики України, Туреччини, проблем безпеки в Чорноморському регіоні та на Близькому Сході.

Електронна адреса: yev.gaber@gmail.com

ГЛЕБОВ Сергій Володимирович, доцент (2008), кандидат політичних наук (2002). Працює на кафедрі міжнародних відносин з 1999 р.; провідний науковий співробітник Центру міжнародних досліджень ОНУ. С політичним оглядачем, автором та ведучим суспільно-політичних програм медіагруппи «ГЛАС». Захистив дисертацію зі спеціальності 23.00.04 - політичні проблеми міжнародних систем та глобального розвитку в ОНУ на тему «Становлення системи безпеки і співробітництва в Чорноморському регіоні та роль України у цьому процесі (1990-і роки)». С автором понад 60 наукових праць.

Електронна адреса: sergglebov@gmail.com 
ДУБОВИК Володимир Алімович, доцент (2000), кандидат політичних наук (1996). Працює в ОНУ з 1992 р. Директор Центру міжнародних досліджень ОНУ (1999). Захистив дисертацію зі спеціальності 23.00.04 - політичні проблеми міжнародних систем та глобального розвитку в ОНУ на тему «Політика США щодо України (1991-1994): аналіз концепцій американської політології». $€$ автором більше 50 наукових праць.

Електронна адреса: volodymyrdubovyk@gmail.com

КОВАЛЬ Ігор Миколайович, професор (2001), доктор політичних наук (2000). Заслужений діяч науки і техніки України. Працює в ОНУ 3 1978 р. Зав. кафедри міжнародних відносин ОНУ (1999-2015); директор Інституту соціальних наук (1996-2010); з 2010 р. - ректор ОНУ. Захистив дисертацію зі спеціальності 23.00.04 - політичні проблеми міжнародних систем та глобального розвитку в ICEMB НАНУ на тему «Концептуальне оформлення східноєвропейської політики США на початку процесу глобальних трансформувань». $\mathcal{C}$ автором більше 80 наукових праць, у тому числі монографії «Последняя битва «холодной войны»: восточноевропейская политика сверхдержав в концепциях зарубежной политологии (80-ые - нач. 90-х гг.)». Головний редактор наукового журналу «Вісник ОНУ. Серія «Політологія» (Одеса, Україна).

Електронна адреса: rector@onu.edu.ua

МАКСИМЕНКО Ірина Володимирівна, кандидат політичних наук (2014). Ст. викладач кафедри міжнародних відносин ОНУ (з 2009 р.), провідний науковий співробітник Центру міжнародних досліджень ОНУ (з 2001 р.). У 2003 р. займала посаду асистента викладача в рамках проекту CEP (Civic Education Project) на базі ОНУ. У 2004-2015 pp. працювала старшим науковим співробітником Одеського регіонального філіалу Національного інституту стратегічних досліджень. Захистила дисертацію зі спеціальності 23.00.04 - політичні проблеми міжнародних систем та глобального розвитку в Чернівецькому національному університеті ім. Юрія Федьковича на тему «Вплив Великобританії, Франції та ФРН на становлення політики Європейського Союзу: економічний, безпековий та зовнішньополітичний виміри». $€$ автором більше 30 наукових праць.

Електронна адреса: ira.maksymenko@gmail.com 
СІНОВЕЦЬ Поліна Андріївна, доцент (2008), кандидат політичних наук (2004). Працює на кафедрі міжнародних відносин ОНУ з 2000 р. Захистила дисертацію зі спеціальності 23.00.04 - політичні проблеми міжнародних систем та глобального розвитку в ICEMB НАНУ на тему «Ядерне стримування в політиці Росії та США в постбіполярний період». 32015 p. очолює Одеський центр с питань нерозповсюдження при ОНУ імені I. I. Мечникова. $€$ автором більше 70 наукових праць. Член редакційної колегії наукового журналу «Вісник ОНУ. Серія «Політологія» (Одеса, Україна), відповідальний редактор наукового журналу «Політичне життя» (Biнниця, Україна).

Електронна адреса: polina.sinovets@gmail.com

ШЕЛЕСТ Ганна Володимирівна, кандидат політичних наук (2012). Членкиня правління Ради зовнішньої політики «Українська призма». Захистила дисертацію зі спеціальності 23.00.04 - політичні проблеми міжнародних систем та глобального розвитку в ICEMB НАНУ на тему «Інститут посередництва в процесі мирного врегулювання воєнних конфліктів». 32004 по 2015 рр. працювала провідним науковим співробітником Одеського філіалу Національного інституту стратегічних досліджень при Президентові України. У 2014 р. була запрошеною дослідницею у Військовому коледжі НАТО в Римі. Головна редакторка англомовного аналітичного журналу «Ukraine Analytica». Головна редакторка щорічника «Оцінки зовнішньої політики України». Авторка більш ніж 50 наукових праць та чисельних аналітичних матеріалів для органів державної влади в Україні та закордоном з тематики безпеки, врегулювання конфліктів, гібридних загроз та Чорноморського співробітництва.

Електронна адреса: shelest@prismua.org

УДОВІК Віолетта Володимирівна, кандидат історичних наук (2018). Стипендіатка Міністерства освіти, культури, спорту, науки та технологій Японії за програмою «стажер-дослідник» (2009-2012рр.). Отримала ступінь магістра права Токійського університету (Японія), в якому пройшла курс з історії зовнішньої політики Японії та міжнародних відносин в Азійсько-Тихоокеанському регіоні. Захистила дисертацію зі спеціальності 07.00.02 - всесвітня історія на тему «Японсько-українські відносини (1991-2016 рр.)» в ОНУ імені I. I. Мечникова. С авторкою понад 20 наукових робіт та публікацій у ЗМI, в тому числі, японською мовою. Академічна членкиня «Інституту мов і культур Європи та Азії» (Японія).

Електронна адреса: violettaudovik@yahoo.co.jp 
За загальною редакиією:

Брусиловської Ольги Іллівни, Дубовика Володимира Алімовича, Коваля Ігоря Миколайовича

\title{
ЧОРНОМОРСЬКИЙ РЕГІОН У СВІТОВІЙ ПОЛІТИЦІ АКТОРИ, ЧИННИКИ, СЦЕНАРІЇ МАЙБУТНЬОГО
}

\section{Монографія}

В авторській редакції

\author{
Комп’ютерна верстка - С. О. Остапенко
}

Підп. до друку 30.11.2020. Формат 60x84/16

Ум.-друк. арк. 10,23. Тираж 100 пр.

Зам. № 2181.

\section{Видавець}

Одеський національний університет імені І. І. Мечникова

Україна, 65082, м. Одеса, вул. Слісаветинська, 12

Тел.: (048) 72328 39. E-mail: druk@onu.edu.ua

Свідоцтво суб’єкта видавничої справи ДК № 4215 від 22.11.2011 p.

\section{Виготовлювач}

Украина, м. Одеса, 65009, вул. Зоопаркова, 25

Свідотство суб'єкта видавничої справи ДК № 1044 від17.09.2002 p.

Тел.. 3805077759 01; 38 (048) 7959160

E-mail: fenix-isd@ukr.net

www: fenixbooks.com 